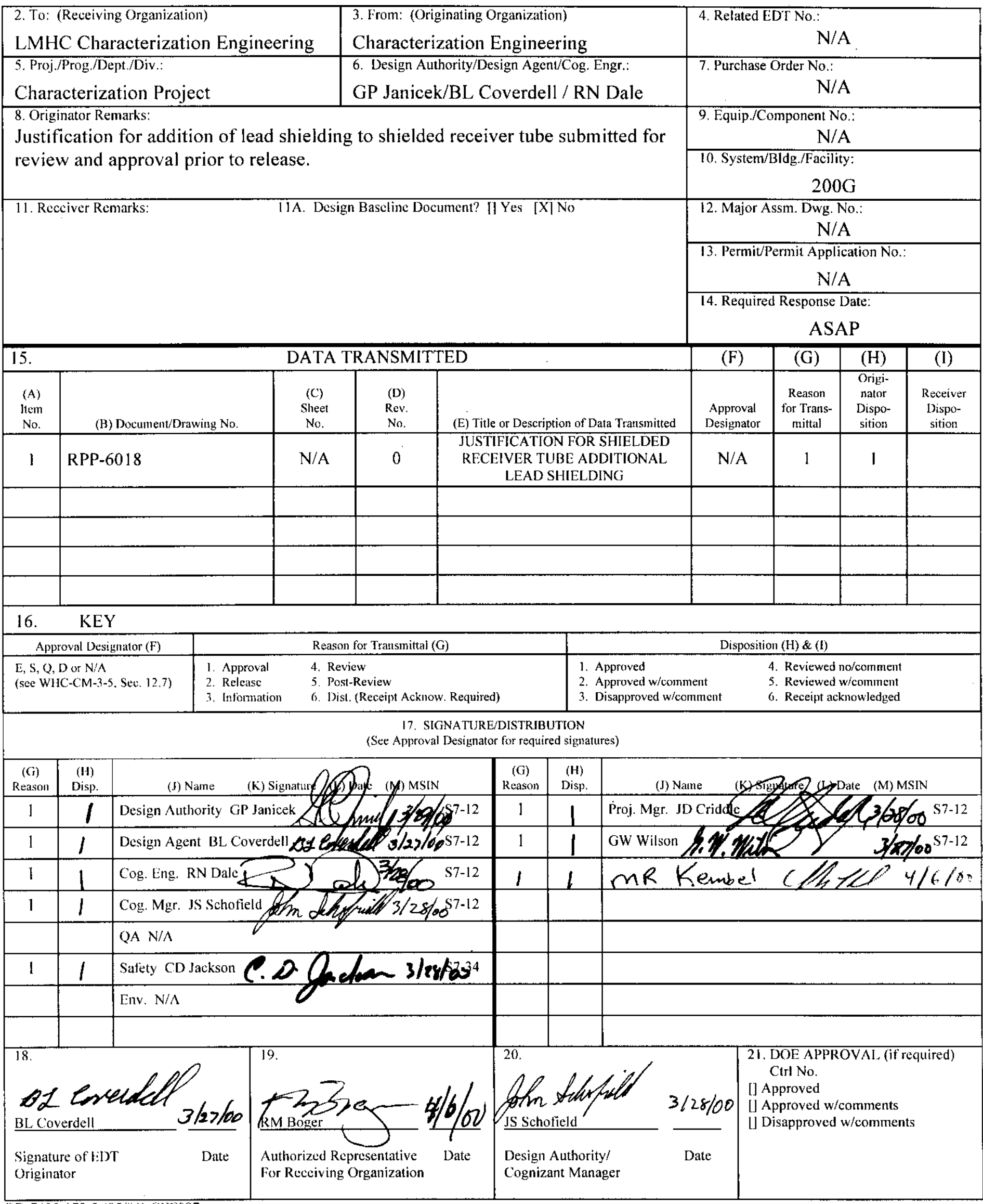




\title{
JUSTIFICATION FOR SHIELDED RECEIVER TUBE ADDITIONAL LEAD SHIELDING
}

\author{
R. M. Boger \\ Prepared by $\mathrm{CH} 2 \mathrm{M}$ Hill Hanford Group, Inc. \\ 2400 Stevens \\ Richland, WA 99352 \\ U.S. Department of Energy Contract DE-AC06-96RL13200
}

EDT/ECN: 627890

Org Code: 74900

B\&R Code: EW 3130000
UC: 2000

Charge Code: CACN: 102250 COA: EI00

Total Pages: $13 \%$

Key Words: Core Sampling, Shielded Receiver, Shielded Receiver Tube, Lead, Shielding

Abstract: In order to reduce high radiation dose rates encountered when core sampling some radioactive waste tanks the addition of $240 \mathrm{lbs}$. of lead shielding is being considered to the shielded receiver tube on core sample trucks \#1, \#3 and \#4. The lead shielding is 4" diameter $\times 1 / 2$ " thick half rounds that have been installed around the SR tube over its' full length. Using three unreleased but independently reviewed structural analyses HNF-6018 justifies the addition of the lead shielding.

TRADEMARK DISCLAIMER. Reference herein to any specific commercial product, process, or service by trade name, trademark, manufacturer, or otherwise, does not necessarily constitute or imply its endorsement, recommendation, or favoring by the United States Government or any agency there of or its contractors or subcontractors.

Printed in the United States of America. To obtain copies of this document, contact: Docume ht Control Services, P.0. Box 950, Mailstop I16-08, Richland WA 99352, Phone (509) 372-2420; Fax (509) 376-4989.
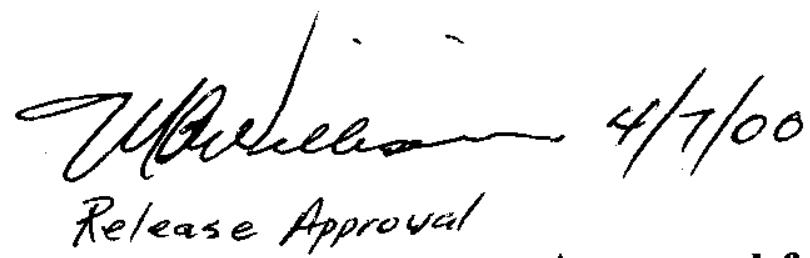

Approved for Public Release

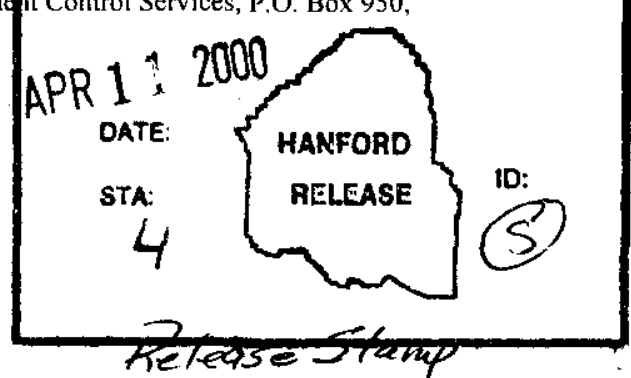


RPP-6018, Rev. 0

JUSTIFICATION FOR SHIELDED RECEIVER TUBE ADDITIONAL LEAD SHIELDING

Prepared for CH2M Hill Hanford Group, Inc.

Characterization Engineering Group

By

B. L. Coverdell

COGEMA Engineering Corporation

March, 2000 


\section{JUSTIFICATION FOR SHIELDED RECEIVER TUBE ADDITIONAL LEAD SHIELDING}

\section{TABLE OF CONTENTS}

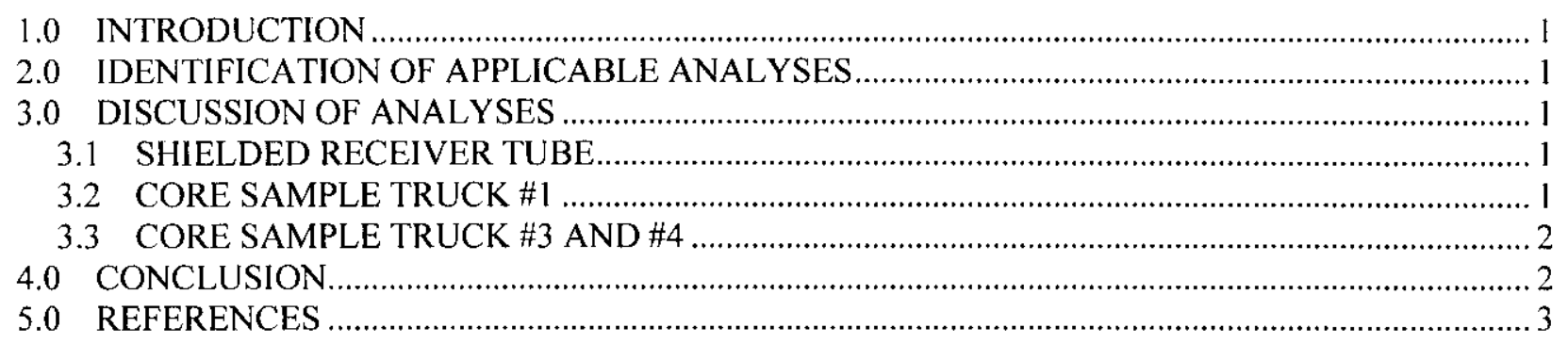

\section{APPENDICES}

Appendix A: Stress Analysis of Shielded Receiver Tube to Support An Additional $250 \mathrm{lbs}$ A-1

Appendix B: Structural and Stress Analysis, Shielded Receiver Lifting Frame, Core Sample Truck \#1

Appendix C: Structural and Stress Analysis, Shielded Receiver Lifting Frame and Jack Assemblies, Core Sample Truck \#3 and \#4. 


\section{JUSTIFICATION FOR SHIELDED RECEIVER TUBE ADDITIONAL LEAD SHIELDING}

\section{$1.0 \quad$ INTRODUCTION}

High radiation doses have been encountered during recent core sampling of Hanford radioactive waste tanks. Temporary lead shielding has been identified for installation on the Shielded Receiver (SR) tube for Core Sample Trucks (CST) \#1, \#3 and \#4. The half round lead shielding installed around the SR tube have a $4 \frac{1 / 2}{2}$ inside diameter and $1 / 2$ " thick wall. The total weight of the lead shielding added is $240 \mathrm{lb}$. The purpose of this document is to verify that the Shielded Receiver Lifting Frames (SRLF) on CSTs \#1, \#3 and \#4 are adequate to support the addition of $240 \mathrm{lbs}$ of lead shielding.

\subsection{IDENTIFICATION OF APPLICABLE ANALYSES}

An engineering calculation was prepared that structurally analyzes the effect of adding $240 \mathrm{lb}$. of lead shielding to the identical SR tubes on CSTs \#1, \#3 and \#4. The engineering calculation in Appendix A, Stress Analysis of Shielded Receiver Tube, is not released into the Hanford Document Control System but has been independently reviewed.

Two structural analyses have been completed analyzing the structural components that make up SRLF (Appendix B). The first analysis is Structural and Stress Analysis, Shielded Receiver Lifting Frame, Core Sample Truck \#1. The second is Structural and Stress Analysis, Shielded Receiver Lifting Frame and Jack Assemblies, Core Sample Truck \#3 and \#4 (Appendix C). Neither of these documents are released into the Hanford Document Control System, however, both documents have been independently Reviewed.

\subsection{DISCUSSION OF ANALYSES}

\subsection{SHIELDED RECEIVER TUBE}

Appendix A contains a short analysis used to determine if the SR tube, the SR tube welds and SR tube to SR Hoist base plate bolted connection on CST \#1,\#3 and \#4 are adequate. The analysis determined that the SR tube and its' structural connections are more than adequate to support an additional $240 \mathrm{lbs}$ of temporary lead shielding.

\subsection{CORE SAMPLE TRUCK \#1}

The text excerpt from the SRLF structural analysis in Appendix B evaluates the structural adequacy of CST \#1 SRLF to support the dead weight of the SR Hoist, SR tube, SRLF structure and associated transportation loads. Page B-11 identifies the maximum SRLF member stresses as being $21,300 \mathrm{psi}$. This stress occurs in the Tube Steel (TS) $2 \times 2 \times 1 / 4$ structural tube members connecting the SR fixed frame to the truck frame.

The analysis conservatively assumes the allowable stress for this member to be based on that for ASTM A36 carbon steel. According to the American Institute of Steel Construction (AISC 1989) for the given section size and yield stress, the allowable stress was determined to be $23,760 \mathrm{psi}$. However, the SRLF $2 \times 2 \times 1 / 4$ structural tube members are actually fabricated using ASTM A500 Grade B material. This material has yield stress of 46,000 psi as opposed to 36,000 psi for ASTM A36 material. Therefore, the allowable stress for the ASTM A500 Grade B material should actually be $30,360 \mathrm{psi}$. This is a $27.8 \%$ increase in the allowable stress for the TS $2 \times 2 \times 1 / 4$. 
The high stress members on CST \#1, the TS $2 \times 2 \times 1 / 4$ structural tube members, are actually TS $3 \times 2 \times 5 / 16$ and TS $3 \times 3 \times 5 / 16$ (see drawings H-2-91715, Sht. 1, Rev. 9, H-2-91716, Sht. 3, Rev. 0, Sht. 4, Rev. 0). Using the smaller sized structural tubing as a reference, the increased size in structural tubing provides a $287 \%$ increase in structural rigidity about the $\mathrm{X}-\mathrm{X}$ axis, $94 \%$ about the $\mathrm{Y}-\mathrm{Y}$ axis and $72 \%$ increase in crosssectional area. In addition to using larger structural tube members, the SRLF has been significantly strengthened to accommodate the addition of hydraulic cylinders with a $13 / 4$ " diameter rod in lieu of cylinders with 1" diameter rods (see ECN 626650).

\subsection{CORE SAMPLE TRUCK \#3 AND \#4}

The text excerpt of the CST \#3 and \#4 SRLF structural analysis in Appendix C evaluates the structural adequacy of the SRLF to support the dead weight of the SR Hoist, SR tube, SRLF structure and associated transportation loads. Page C-14 identifies the maximum SRLF member stresses as being 23,740 psi. This stress occurs in the TS $2 \times 2 \times 1 / 4$ structural tube members connecting the SR fixed frame to the truck frame.

The analysis conservatively assumes the allowable stress for this member to be based on that for ASTM A36 carbon steel. According to AISC 1989 given the section size and yield stress, the allowable stress was determined to be $23,760 \mathrm{psi}$. However, the SRLF $2 \times 2 \times 1 / 4$ structural tube members are actually fabricated using ASTM A500 Grade B material. This material has yield stress of $46,000 \mathrm{psi}$ as opposed to $36,000 \mathrm{psi}$ for ASTM A 36 material. Therefore, from AISC 1989 the allowable stress for the ASTM A500 Grade B material should actually be $30,360 \mathrm{psi}$. This is a $27.8 \%$ increase in the allowable stress for the TS $2 \times 2 \times 1 / 4$.

On CSTs \#3 and \#4, the members determined to have the highest stresses (TS $2 \times 2 \times 1 / 4$ connecting the SR fixed frame to the CST frame) were analyzed as simple shapes when, in fact, they are composite shapes. The TS $2 \times 2 \times 1 / 4$ have $1 / 4$ " gusset plates welded between them and the CST frame (see H-2-690043, Rev. 2, zone F-4). The addition of the gusset plates significantly increases the structural capacity of the TS $2 \times 2 \times 1 / 4$ connecting members. In addition, the SRLF has been significantly strengthened to accommodate the addition of hydraulic cylinders with a $13 / 4$ " diameter rod in lieu of cylinders with 1" diameter rods (see drawings H-2-690043, Rev. 2 and H-2-690044, Sht. 1, Rev. 3 and Sht 2, Rev. 2).

\subsection{CONCLUSION}

Half round lead shielding weighing equal to or less than $240 \mathrm{lb}$ may be added to the SR tube on CST \#1, \#3 and \#4 based on the following facts:

- The structural analysis of the SR tube, the SR tube welds and SR tube to SR hoist base plate bolted connections determined that the structural integrity was more than adequate to support the additional load.

- Both analyses of the SRLFs (Appendices B \& C) use a very conservative allowable stress for the evaluation of the SRLFs structural tubing.

- Structural modifications increasing the strength of the SRLFs were made subsequent to the performance of the analyses in appendices $\mathrm{B}$ and $\mathrm{C}$. The modifications increased the strength of the high stress members of the SRLFs for all three CSTs.

Operational loading of SRLF was not considered by either of the structural analyses in the appendices B or $\mathrm{C}$, however, after review of the analyses it was determined that transportation loads (longitudinal $=-.43 \mathrm{~g}$, lateral $=.37 \mathrm{~g}$ and vertical $=-.18 \mathrm{~g}$ ) bound all operational loads. Review of the structural analysis of the SR tube and SR tube connections in Appendix A determined that it is adequate to support operational loading. 
RPP-6018, Rev. 0

\subsection{REFERENCES}

AISC, 1989, Manual of Steel Construction - Allowable Stress Design, American Institute of Steel Construction, Ninth Edition, Chicago, Illinois. 
RPP-6018, Rev. 0

Appendix A: Stress Analysis of Shielded Receiver Tube.

A-1 
TWRS ADMINISTRATION

TEMPORARY SHIELDING
Manual

Volume

Section

Page

Effective Date
HNF-IP-0842

VII, Radiological Control

3.2 , REV 2

8 of 10

July 31,1998

Figure 1. Temporary Shielding Authorization Form.

TEMPORARY SHIELDING AUTHORIZATION

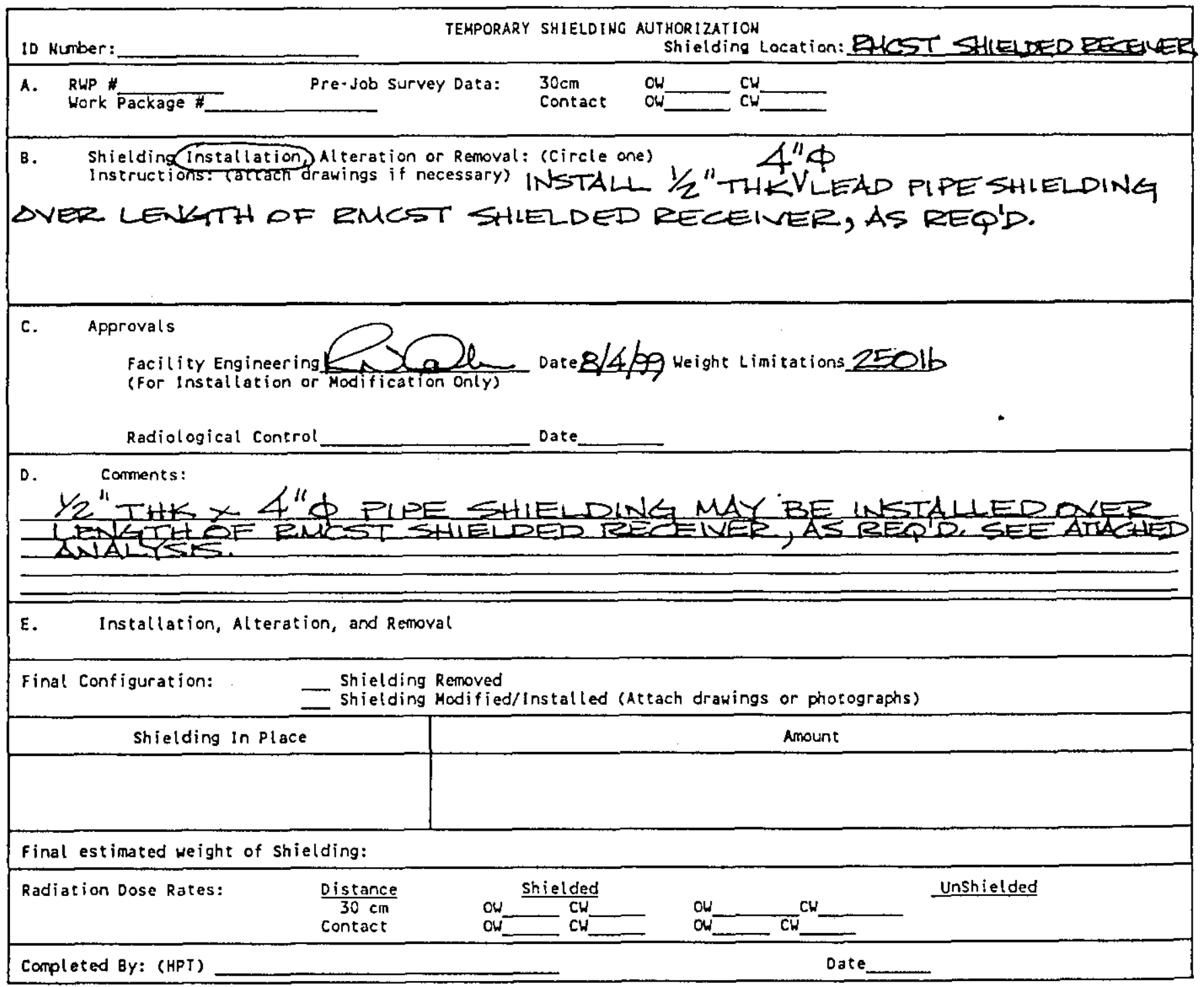




\section{DESIGN ANALYSIS}

Calc. No

Revision

Page No.

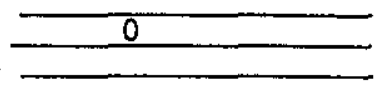

Client: Characterization Equipment

WO/Job No.

Subject: Shielded Receiver Tube Analysis

Date: $8 / 04 / 99$

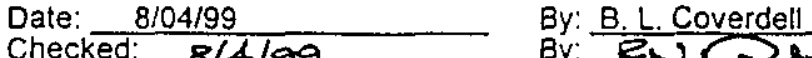

Revised:

By.

1.0 OBJECTIVE This set of calculations determines the adequacy the shielded receiver tube to carry an additional loading of $250 \mathrm{lb}$ due to lead shielding.

2.0 DESIGN INPUTS

2.1 Drawing: H-2-690020 Rev, 3

\subsection{ASSUMPTIONS}

3.1 None

4.0 METHODS OF ANALYSIS (Hand calculations completed in Mathcad ver. 8.0)

\subsection{REFERENCES}

5.1 AISC, 1989, Manual of Steel Construction, 9th Edition, American Institute of Steel Construction, Chicago, Illinois.

5.2 Blodgett, OW, 1991, Design of Welded Structures, Fourteenth Printing. The James F. Lincoln Arc Welding Foundation, Cleveland, Ohio.

6.0 FINDINGS AND CONCLUSIONS The calculations below determine the shielded receiver tube is adequate to carry the exected $250 \mathrm{lbf}$ additional loading with a large factor-of-safety.

\subsection{CALCULATIONS}

7.1 Determine the loads on the shielded receiver tube and include the addition of lead shield.

Tube $:=250 \cdot 16 f$

$L:=77 \cdot$ in $-1.12 \cdot$ in $-.75 \cdot$ in

Tube $_{4}:=\mathrm{L} \cdot 10.79 \frac{\mathrm{lbf}}{\mathrm{ft}}$

Tube $2:=L \cdot 3.65 \cdot \frac{\mathrm{lbf}}{\mathrm{ft}}$

Lead $:=L \cdot\left[\frac{\pi}{7} \cdot\left[(10.02 \cdot \text { in })^{2}-(2.375 \cdot \mathrm{in})^{2}\right]\right] \cdot 710 \cdot \frac{\mathrm{lbf}}{\mathrm{ft}^{3}}$

Flange $:=\frac{\pi}{4} \cdot\left[(8.5 \cdot \mathrm{in})^{2}-(2.39 \cdot \mathrm{in})^{2}\right] \cdot .75 \cdot \mathrm{in} \cdot 490 \cdot \frac{\mathrm{lbf}}{\mathrm{ft}^{3}}$
$L=6.261 \mathrm{ft}$

Tube $_{4}=67.554 \cdot \mathrm{lbf}$

Tube $_{2}=22.852 \cdot \mathrm{lb}$

Lend $=2297 \cdot \mathrm{Jbf}$

Flange $=11.114 \cdot 16 \mathrm{f}$

Weight of lower flange.

Weight of ball valve, view port and dust cap is estimated at $100 \mathrm{lb}$

$W_{\text {total }}:=$ Tube + Tube $_{2}+$ Tube $_{4}+$ Lead + Flange $\quad W_{\text {total }}=2649 \cdot \mathrm{lbf} \quad$ Misc weight.

7.2 Assuming the $4^{\prime \prime}$ sch 40 pipe carries the entire load, determine the maximum stress in pipe. 

$\mathrm{A}_{4}:=3.17 \cdot \mathrm{in}^{2}$
Cross sectional area of $4^{\prime \prime} \operatorname{sch} 40$ pipe.
$\sigma_{t}:=\frac{W_{\text {total }}}{A_{4}}$
${ }^{\circ} \mathrm{t}=835.629 \cdot \mathrm{psi}$
OK

7.3 Determine the adequacy of the $1 / 4$ " weld attaching the 4 " sch 40 pipe to the upper flange.

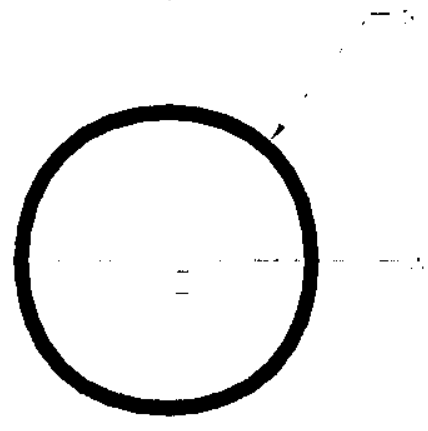

$$
\begin{aligned}
& \mathrm{d}:=4.5 \cdot \mathrm{in} \quad \text { Diameter of weld. } \\
& w_{a}:=\frac{1}{4} \cdot \text { in } \quad \text { Weld size. } \\
& \sigma_{\text {base }}:=36000 \text { psi Yield stress of the base metal. } \\
& \sigma^{\circ} \text { weld }:=60000 \text {.psi Yield stress of the weld matal. } \\
& F_{x}:=0.1 b f \\
& F_{y}:=0 \cdot 1 b f \\
& F_{z}:=W_{\text {total }} \\
& M_{x}:=0 \cdot \text { in } \cdot 1 b f \\
& M_{y}:=0 \cdot i n \cdot l b f \\
& M_{z}:=0 \cdot \text { in } \cdot 1 b f
\end{aligned}
$$

Weld Properties per Blodgett 1991

$$
\begin{array}{lll}
C_{x}:=\frac{d}{2} & C_{x}=2.25 \cdot \mathrm{in} & \text { The distance to the outer fiber in the } x \text {-direction. } \\
C_{y}:=\frac{d}{2} & C_{y}=2.25 \cdot i n & \text { The distance to the outer fiber in the } y \text {-direction. } \\
A_{w}:=\pi \cdot d & A_{w}=14.137 \cdot \mathrm{in} & \text { The linear area of the weld. } \\
S_{w x}:=\frac{\pi \cdot d^{2}}{4} & S_{w x}=15.904 \cdot \mathrm{in}^{2} & \text { The linear section modulus about the } x \text {-axis. } \\
S_{w y}:=\frac{\pi \cdot d^{2}}{4} & S_{w y}=15.904 \cdot \mathrm{in}^{2} & \text { The linear section modulus about the } y \text {-axis. } \\
J_{w}:=\frac{\pi \cdot d^{3}}{4} & J_{w}=71.569 \cdot \mathrm{in}^{3} & \text { The linear polar moment of inertia. }
\end{array}
$$

Linear Weld Stress:

$$
f_{w}:=\sqrt{\frac{F_{z}}{A_{w}}+\frac{M_{x}}{S_{w x}}+\frac{M_{y}}{S_{w y}}+\frac{F_{x}}{A_{w}}+\frac{M_{z} \cdot C_{y}{ }^{2}}{J_{w}}+\frac{F_{y}}{A_{w}}+\frac{M_{z} \cdot C_{x}{ }^{2}}{J_{w}}} \quad f_{w}=187.375 \cdot \frac{\mathrm{lbf}}{\text { in }}
$$

Required Fillet Weld Size:

$$
\mathrm{v}_{\mathrm{r}}:=\operatorname{if}\left[\frac{\mathrm{f}_{\mathrm{w}}}{0.707 \cdot(0.3) \cdot \sigma_{\text {weld }}} \leq \frac{\mathrm{f}_{\mathrm{w}}}{0.4 \cdot \sigma_{\text {base }}}, \frac{\mathrm{f}_{\mathrm{w}}}{0.4 \cdot \sigma_{\text {base }}}, \frac{\mathrm{f}_{\mathrm{w}}}{0.707 \cdot(0.3) \cdot \sigma_{\text {weld }}}\right] \quad \mathrm{w}_{\mathrm{r}}=0.015 \cdot \text { in }
$$

0.707 is for shear through throat of fillet weld, 0.3 is allowable stress reduction factor for shear through throat of fillet weld and 0.4 is for shear on base metal. See AISC 1989, Table J2.5, Page5-70.

The Margin of Safety:
FS $:=\frac{w_{a} a}{w_{r}}$
$\mathrm{FS}=16.979$
OK 
RPP-6018, Rev. 0

Completed By:

Checked By:

7.4 Check bolts attaching upper flange and shielded receiver tube to the hoist box.
$n:=8$
Number of 5/8" A193 bolts.
$\sigma_{\text {t_allow }}:=90000 \cdot \mathrm{psi} \quad$ Minimum yield stress for an A193 bolt (no class specified).
$W_{\text {flange }}:=\frac{\pi}{4} \cdot\left[(13.5 \cdot \mathrm{in})^{2}-(2.39 \cdot \mathrm{in})^{2}\right] \cdot 1.12 \cdot \mathrm{in} \cdot 490 \cdot \frac{\mathrm{lbf}}{\mathrm{ft}^{3}}$
$W_{\text {flange }}=44.035 \cdot \mathrm{lbf}$
Weight of upper flange.
$W_{\text {total }}:=W_{\text {total }}+W_{\text {flange }}$
Total weight of shielded receiver tube assembly.
$A_{c}:=.202 \cdot i^{2}$
Cross sectional area of a $5 / 8^{\prime \prime}$ bolt.
$\sigma_{t}:=\frac{W_{\text {total }}}{n \cdot A_{c}}$
$\sigma_{t}=1666 \cdot p s i$
Maximum stress in a $5 / 8^{\prime \prime}$ bolt.
FS $:=\frac{{ }^{0} \text { t_allow }}{\sigma_{t}}$
$\mathrm{FS}=54.007$
OK 


\section{ADVANCED SHIELDING TECHNOLOGY, LLC PRICING STRUCTURE \\ EFFECTIVE DATE: May 1, 1999_(rev.1)}

I. Coated Pipe Shields, $0.50^{\prime \prime}$ thick lead, price per liner foot

\begin{tabular}{|c|c|c|c|c|}
\hline \multirow{2}{*}{ PIPE } & \multicolumn{2}{|c|}{ RadKlad 140 } & \multicolumn{2}{c|}{ Metalized } \\
\cline { 2 - 5 } & Half Round & Full Round & Half Round & Full Round \\
\hline 4" or less $^{\prime \prime}$ & $\$ 80$ & $\$ 160$ & $\$ 94$ & $\$ 238$ \\
\hline $6^{\prime \prime}$ & $\$ 105$ & $\$ 210$ & $\$ 119$ & $\$ 300$ \\
\hline $8^{\prime \prime}$ & $\$ 124$ & $\$ 248$ & $\$ 147$ & $\$ 372$ \\
\hline $10^{\prime \prime} \& 12^{\prime \prime}$ & $\$ 140$ & $\$ 280$ & $\$ 166$ & $\$ 420$ \\
\hline $14^{\prime \prime} \& 16^{\prime \prime \prime}$ & $\$ 140$ & $\$ 280$ & $\$ 166$ & $\$ 420$ \\
\hline $18^{\prime \prime} \& 20^{\prime \prime}$ & $\$ 150$ & $\$ 300$ & & \\
\hline
\end{tabular}

II. Coated Pipe Elbow Shields, $0.50^{\prime \prime}$ thick lead, price per elbow

\begin{tabular}{|c|c|c|c|c|}
\hline \multirow{2}{*}{ PIPE } & \multicolumn{2}{|c|}{ RadKJad 140 } & \multicolumn{2}{c|}{ Metalized } \\
\cline { 2 - 5 } & Half Round & Full Round & Half Round & Full Round \\
\hline $4^{\prime \prime}$ or less & $\$ 168$ & $\$ 336$ & $\$ 199$ & $\$ 505$ \\
\hline $6^{\prime \prime}$ & $\$ 248$ & $\$ 496$ & $\$ 294$ & $\$ 742$ \\
\hline $8^{\prime \prime}$ & $\$ 360$ & $\$ 720$ & $\$ 427$ & $\$ 1,078$ \\
\hline $10^{\prime \prime}$ & $\$ 518$ & $\$ 1036$ & $\$ 615$ & $\$ 1,554$ \\
\hline $12^{\prime \prime}$ & $\$ 835$ & $\$ 1,670$ & $\$ 993$ & $\$ 2,505$ \\
\hline $14^{\prime \prime}-20^{\prime \prime}$ & $\$ 900$ & $\$ 1800$ & & \\
\hline
\end{tabular}




\section{ADVANCED SHIELDING TECHNOLOGY, LLC}

III. Coated Shield Panels, 0.25" thick lead

\begin{tabular}{|c|c|c|c|}
\hline SIZE & RadKlad 140 & & Metalized \\
\hline $1^{\prime} \times 3^{\prime}$ & $\$ 130$ & & $\$ 210$ \\
\hline $1^{\prime} \times 4^{\prime}$ & $\$ 160$ & & $\$ 245$ \\
\hline $2^{\prime} \times 4^{\prime}$ & $\$ 225$ & & $\$ 295$ \\
\hline
\end{tabular}

* includes 4 grommetted holes

V. Coated Valve Shields, 0.75" thick lead

\begin{tabular}{|c|c|c|c|}
\hline VALVE SIZE & RadKlad 140 & RadKlad 340 & Metalized \\
\hline 3/4" to 1" & $\$ 470$ & & $\$ 705$ \\
\hline $2 "$ & $\$ 575$ & & $\$ 860$ \\
\hline 3/4" to 1" Karotest & $\$ 575$ & & $\$ 860$ \\
\hline
\end{tabular}

V. Whole Body Monitor Shield Enclosure

Specifications (standard model):

- will accommodate most whole body monitors is use (IPM, PCM, etc.)

- modular dimensions

- $\quad$ single entry/exit

- $\quad$ seismic qualification available

- modular design allows for easy installation and removal of individual shield panels

- modular design allows for easy access to whole body monitor for maintenance

- $\quad$ safe and easy assembly/disassembly

- $\quad$ side shielding available up to $1.0^{\prime \prime}$ lead thickness in $1 / 4^{\prime \prime}$ increments

- roof shielding available up to $1 / 2$ " lead thickness in $1 / 4^{\prime \prime}$ increments

- $\quad$ stainless steel panel finish

- options available at Customer request

- Special Design Whole Body Monitor Shield Enclosures available

Prices (standard model):

- $1 / 4^{\prime \prime}$ thick lead shielding on sides and roof

- $1 / 2^{2}$ thick lead shielding on sides and roof

- $\quad 3 / 4^{\prime \prime}$ thick lead shielding on sides, $1 / 2$ " thick on roof

- $1.0^{\prime \prime}$ thick lead shiclding on sides, $1 / 2^{21}$ thick on roof 
RPP-6018, Rev. 0

ADVANCED SHIELDING TECHNOLOGY, LLC

Notes:
1. $\quad \begin{aligned} & \text { All prices are subject to change without notification. } \\ & \text { 2. }\end{aligned}$
$\begin{aligned} & \text { Prices are non-inclusive of handling and freight charges, installation } \\ & \text { materials (fasteners), or installation support services, if applicable. } \\ & \text { Products shown here are indicative of most commonly fabricated shield } \\ & \text { products. Please contact us for pricing on other shielding products. }\end{aligned}$
4. $\quad$ Fabrication of special size valve shiess requests for all special shield designs.

\section{WEIGHT INFORMATION}

I. Pipe Shields_(0.5" thick lead)

$\begin{array}{ll}\text { Diameter } & \text { Weight per liner foot (half-round shield coverage) } \\ & \\ 1^{\prime \prime} & 6.75 \mathrm{lbs} \\ 2^{\prime \prime} & 11.5 \\ 3^{\prime \prime} & 15.5 \\ 4^{\prime \prime} & 19.75 \\ 5^{\prime \prime} & 23.75 \\ 6^{\prime \prime} & 28 \\ 8^{\prime \prime} & 35.5 \\ 10^{\prime \prime} & 45 \\ 12^{\prime \prime} & 53.25\end{array}$

n. Valve Shields $\left(0.75^{\prime \prime}\right.$ thick lead)

Valve size Weight

$\begin{array}{ll}3 / 4^{\prime \prime} & 15 \mathrm{lbs} \\ l^{\prime \prime} & 15 \\ 2^{\prime \prime} & 80\end{array}$

III. Shield Panels (1/4" thick)

15 lbs per square foot 
RPP-6018, Rev. 0

Appendix B: Structural and Stress Analysis, Shielded Receiver Lifting Frame, Core Sample Truck \#1

B-1 


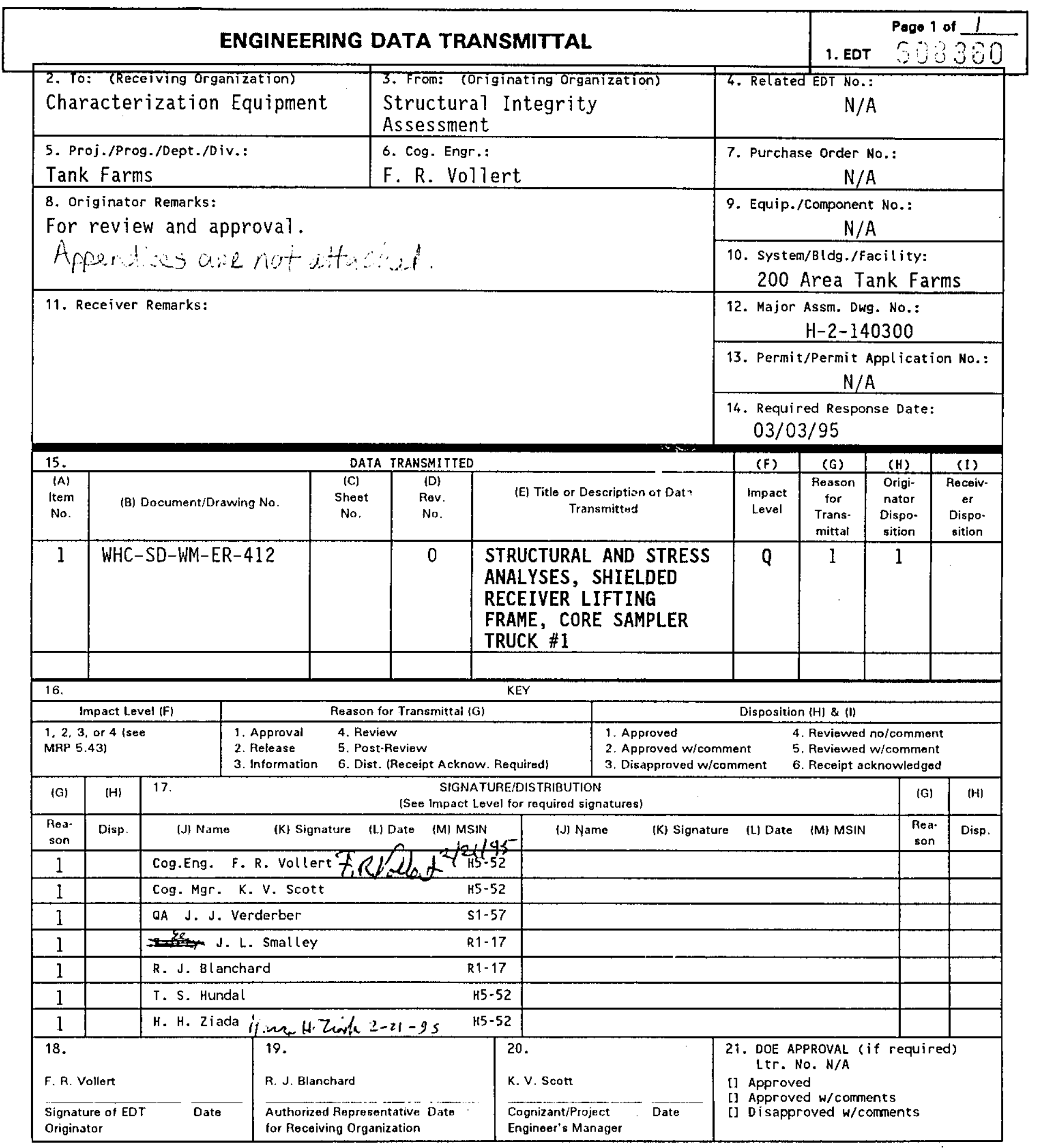


RPP-6018, Rev. 0

\section{STRUCTURAL AND STRESS ANALYSES, SHIELDED RECEIVER LIFTING FRAME, CORE SAMPLER TRUCK \# 1}

\subsection{INTRODUCTION}

Structural and stress analyses have been conducted for the shielded receiver lift frame (SRLF) mounted on core sampler truck number 1 . Analyses cases were: the normal operational static vertical (deadweight) loads and the deadweight combined with additional static vertical and horizontal loads intended to account for the potential demands of transporting the SRLF on the truck.

The SRLF is a space frame structure with welded joints. It is fabricated from various size structural steel tubes, except the two main members for the fixed frame portion are 6 inch deep channels. The objectives of the structural analyses include determining and evaluating the stresses in the frame members and the weld joints. Three dimension static finite (beam) element analyses of the SRLF were conducted (Images 1993) with models to represent the SRLF in the raised and lowered position, and to envelope the restraint provided by the welded attachments to the truck. Fully fixed joints were used in the finite element models. The results were member (beam) stresses and joint forces. The joint forces were used to calculate the weld stresses for the joints with methods from Blodgett 1982 . The member and weld stresses were evaluated and determined to be in conformance with AISC 1989 and AWS 1992. The analyses results do not predict the potential affects of residual stresses, cyclic stresses, stress concentrations, and potential defects. The welds, including the attachments to the truck, should frequently be thoroughly cleaned and visually inspected.

\subsection{CONCLUSIONS AND RECOMMENDATIONS}

The SRLF structural analyses results are the stresses and joint forces for the structural members. The joint forces were then used to calculate the welded joint stresses, including the stresses in the gusset plates that stiffen 4 joints. These calculated member and weld stresses all are within the allowable values. However, the SRLF structural member ends are simply and directly welded together at the joints or connections. Therefore, the analyses and the results do not predict or incorporate the potential affects of:

- residual stresses due to fabrication

- cyclic stress changes during operation and transportation (fatigue)

- stress concentrations, sharp corners, and potential defects in the welded joints.

The computed stresses in the members and welds would directly superimpose with residual stresses. This increases the potential for overstress under alt load conditions, particularly for the welds. Cyclic stresses have the 
potential to initiate and propagate fatigue cracks. Again the welds with the higher likelihood for stress concentrations and defects are the most vuinerable. Further more comprehensive analyses to account for these potential effects could be conducted. A number of enveloping assumptions would be necessary. It is believed that, after further analyses, too many uncertainties would remain to eliminate this concern.

It is recommended that the weld joints in the SRLF and the attachments to the truck be thoroughly cleaned and visually inspected frequently. For example, after each 30 days of operation, and after each relocation to another tank farm. The inspections would be for evidence of structural and joint distress including cracks. They should be frequent, because visual inspection may not be able to find cracks before they have advanced considerably.

In the event structural distress occurs where joint repair is necessary, evaluation should be made to determine if the design details can be readily improved.

\subsection{MATERIALS AND ALLOHABLE STRESSES}

Design drawing H-2-91716 (WHC 1994b) for the SRLF specifies either ASTM A36 or ASTM A500, Grade B steel for the structural tubes and channels. The steel plates and other components used are ASTM A36. The weld metal used has a specified minimum ultimate strength of $70,000 \mathrm{lbf} / \mathrm{in}^{2}$.

\section{I STRUCTURAL STEEL STRENGTH AND ALLOWABLE STRESSES}

The strength, allowable stresses, and other material properties used for all the structural steel members and components in the SRLF were established conservatively from ASTM A36 steel minimum specifications as follows:

$\begin{aligned} \text { Modulus of Elasticity, } E & & =29,000,000 \mathrm{lbf} / \mathrm{in}^{2} \\ \text { Shear Modulus, } G & & =11,200,000 \mathrm{lbf} / \mathrm{in}^{2} \\ \text { Poisons Ratio, } \mu & & =0.300 \\ \text { Ultimate Tensile Strength, } F_{u} & & =58,000 \mathrm{lbf} / \mathrm{in}^{2} \\ \text { Yield Strength, Fy } & & =36,000 \mathrm{lbf} / \mathrm{in}^{2} \\ \text { Allowable Axial Stress, } F_{t} & & =0.60 \times F_{y}=21,600 \mathrm{lbf} / \mathrm{in}^{2} \\ \text { Allowable Bending Stress, } F_{b} & & =0.66 \times F_{y}=23,760 \mathrm{lbf} / \mathrm{in}^{2} \\ \text { Allowable Shear Stress, } F_{v} & & =0.40 \times F_{y}=14,400 \mathrm{lbf} / \mathrm{in}^{2}\end{aligned}$


RPP-6018, Rev. 0

\subsection{WELD ALLOWABLE STRENGTH}

The ultimate and allowable strength for the welds joining the SRLF structural members were established in accordance with the Structural Welding code (AWS 1992), and the Manual of Steel Construction (AISC 1989). These force per unit length values are determined based on the minimum ultimate strength $\left(F_{\text {uwm }}\right)$ of the weld metal, and the thickness $\left(t_{w}\right)$ of the weld as follows:

$$
\begin{aligned}
& \text { Weld Metal Ultimate Strength, } F_{\text {uwm }}=70,000 \mathrm{lbf} / \mathrm{in}^{2} \\
& \text { Fillet Weld Ultimate Strength, } F_{u H}=0.707 \times t_{w} \times F_{u w m} 1 \mathrm{bf} / \text { in } \\
& \text { Fillet Weld Allowable Strength }{ }^{1}, F_{w}=0.30 \times F_{u w}=14,800 \times t_{w} 1 \mathrm{bf} / \text { in }
\end{aligned}
$$

\subsection{CONFIGURATION AND LOADS}

The configuration of the SRLF structure for core sampler truck 1 obtained from the design drawing $\mathrm{H}-2-91716$ (WHC 1994b) is shown in Figures 1, 2, and 3 . It is a space frame structure with welded joints. It is fabricated from various size structural steel tubes, except the two main members for the fixed frame portion are 6 inch deep channels. The fixed frame and its two bracing members are welded to the truck. The moveable portion is raised and lowered during normal operation by the two vertical actuators. Figure 1 also shows the location of the normal operation vertical static (deadweight) loads on the moveable portion of the structure. These loads (maximum) are: the sampler hoist shielded receiver box and base plate (1,900 lbf), plus the shielded sampler tube $(2,800 \mathrm{lbf})$.

The maximum allowable speed on paved roadways is $15 \mathrm{mi} / \mathrm{h}$ for the core sampler truck 1. This limit was established to prevent truck rollover from the results of a previous anaiysis for core sampler truck 2 (WHC 1994a). The potential demands of transporting the SRLF on the truck at the $15 \mathrm{mi} / \mathrm{h}$ maximum allowed speed, also estimated by the rollover analysis for truck 2 (WHC 1994a), are represented as additional static forces on the SRLF. These are: $0.18 \mathrm{~g}$ vertical, $0.43 \mathrm{~g}$ longitudinal, and $0.37 \mathrm{~g}$ lateral. The moveable portion of the SRLF is only in the lowered position during transport.

\subsection{STRUCTURAL ANALYSES AND RESULTS}

Three dimension finite element static analyses were conducted for the SRLF structure (Images 1993) for the normal operation deadweight loads, and for deadweight combined with the additional transportation loads. Finite beam element models with the SRLF in the raised and lowered position were developed and used. Also, the fixed frame was both: modeled to be fully restrained at all welds to the truck, and with only the two braces providing the overturning restraint. Fully fixed joints were used in the finite element models, because the SRLF structural member ends are simply and directly welded together at the

${ }^{1}$ For fillet weld $\left(t_{H}\right)=3 / 16$ in., $\left(F_{H}\right)=2775 \mathrm{lbf} / \mathrm{in}$. 
RPP-6018, Rev. 0

joints or connections. Four of the SRLF connections are stiffened with gusset plates.

Four deadweight loads analyses cases were run. This was necessary to obtain analyses results for the SRLF in both the raised and lowered position, and for the two restraint conditions assumed for the fixed frame. Four transportation loads analyses cases were run with the SRLF in the lowered position. This was necessary to obtain analyses results for both forward and aft direction longitudinal loads, and for the two restraint conditions assumed for the fixed frame. The finite (beam) element models are described in detail, and all the Images 1993 analyses results are provided in Appendix A.

The Images 1993 analyses results include the forces and moments in the members and joints, and the member stresses. The bending, axial, shear, and combined stresses are calculated for each beam element in the SRLF model. The maximum bending, shear, and combined stress values in the SRLF members for deadweight loads, and the transportation loads are listed and compared to the allowable in Table 1 and Table 2, respectively. All of the calculated potential stresses in SRLF structural members are within the allowable.

The stresses in the weld joints due to the member/joint forces and moments were calculated. Weld stress analysis methods from Blodgett 1982 were used. The weld joint stress calculations and evaluations are provided in Appendix B. Table 3 lists the maximum potential weld stresses for the normal deadweight loads, and transportation loads. For comparison, the allowable weld strengths for the welds are also listed in Table 3 . All of the calculated potential weld stresses in the SRLF joints are within the allowable strengths. For the normal deadweight loads the calculated weld stresses, with few exceptions, are very low. For the additional transportation loads, most of the calculated weld stresses increase significantly. Two of the weld joint stresses essentially equal their allowable strength. Several others are within $20 \%$ of the allowable strength.

It was also necessary to use member/joint forces to calculate the bending stresses in the gusset plates that stiffen 4 joints in the SRLF. The maximum calculated bending stresses in the plates for the deadweight and transportation load cases are $10,318 \mathrm{lbf} / \mathrm{in}^{2}$ and $14,085 \mathrm{lbf} / \mathrm{in}^{2}$, respectively. These are within the 23,760 1bf/in ${ }^{2}$ allowable bending stress. 
RPP-6018, Rev. 0

\subsection{REFERENCES}

AISC, 1989, Manual of Steel Construction, Allowable Stress Design, Ninth Edition, American Institute of Steel Construction, Chicago, Illinois.

ASTM, 1989, Annual Book of ASTM Standards, American Society for Testing and Materials, Philadelphia, Pennsylvania.

AWS, 1992, Structural Welding Code-Steel, ANSI/AWS D1.1-92, American Welding Society, Miami, Florida

Blodgett, 0. W., 1982, Design of Welded structures, James F. Lincoln Arc Welding Foundation, Cleveland, Ohio

Images, 1993, Interactive Microcomputer Analysis and Graphics of Engineering systems, IMAGES-3D, Version 3.0, RLCA/Celestial Software, Berkeley, California.

WHC, 1994a, Rollover Analysis of Rotary Mode Core Sampler Truck $\ddot{\pi} 2$, WHC-SD-WM-ER-391, Rev. 0, Westinghouse Hanford Company, Richland, Washington.

WHC, 1994b, Shielded Receiver Lifting Frame Assembly, Core Sample Truck, Drawing Number H-2-91716, Sheets 1 to 4, Westinghouse Hanford Company, Richland, Washington. 
FIGURE I: SHIELDED RECEIVER LIFTING FRAME ASSEMBLY

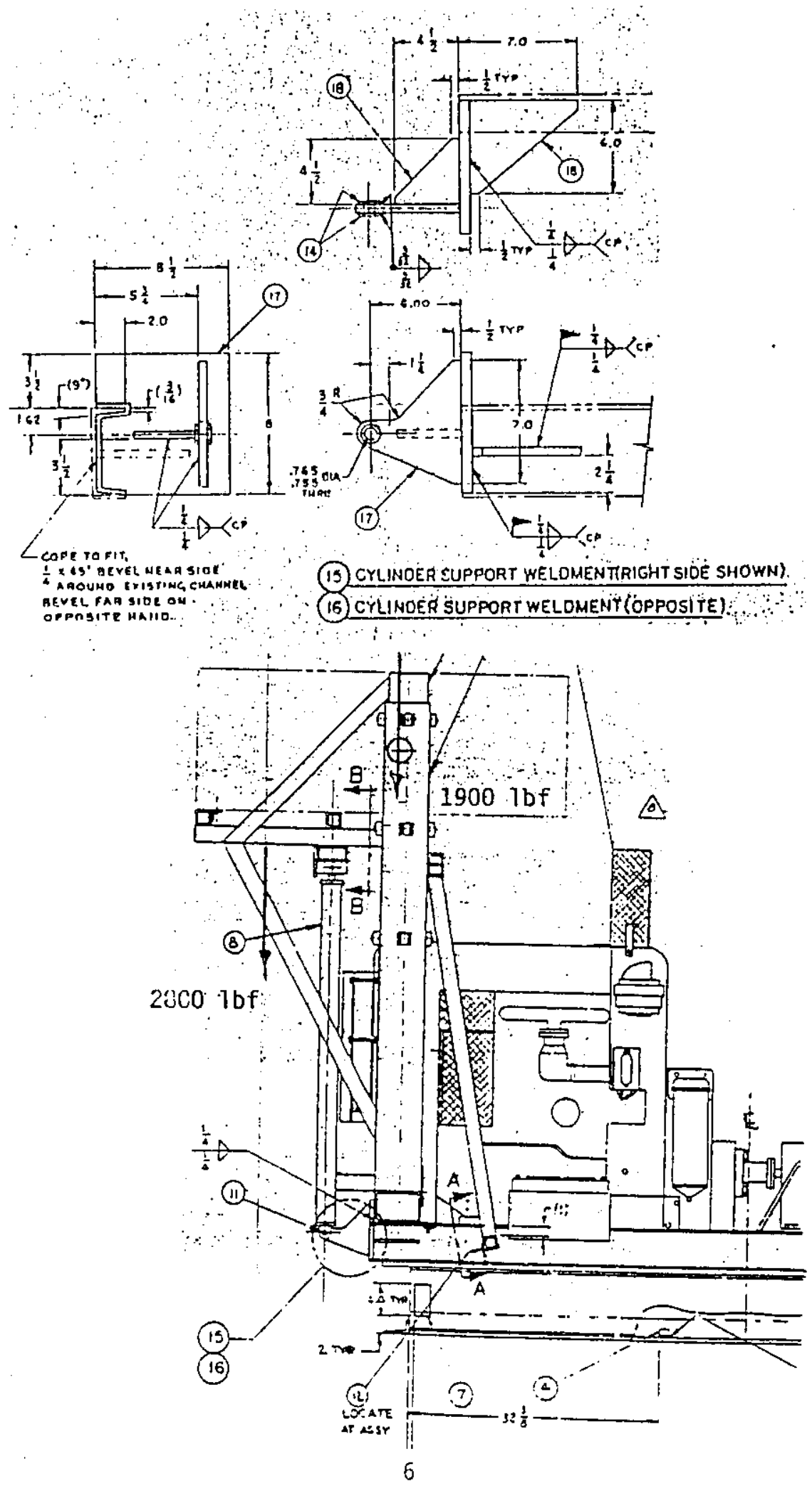


FIGURE 2: SHIELDED RECEIVER SUPPORT FRAME ASSEMBLY
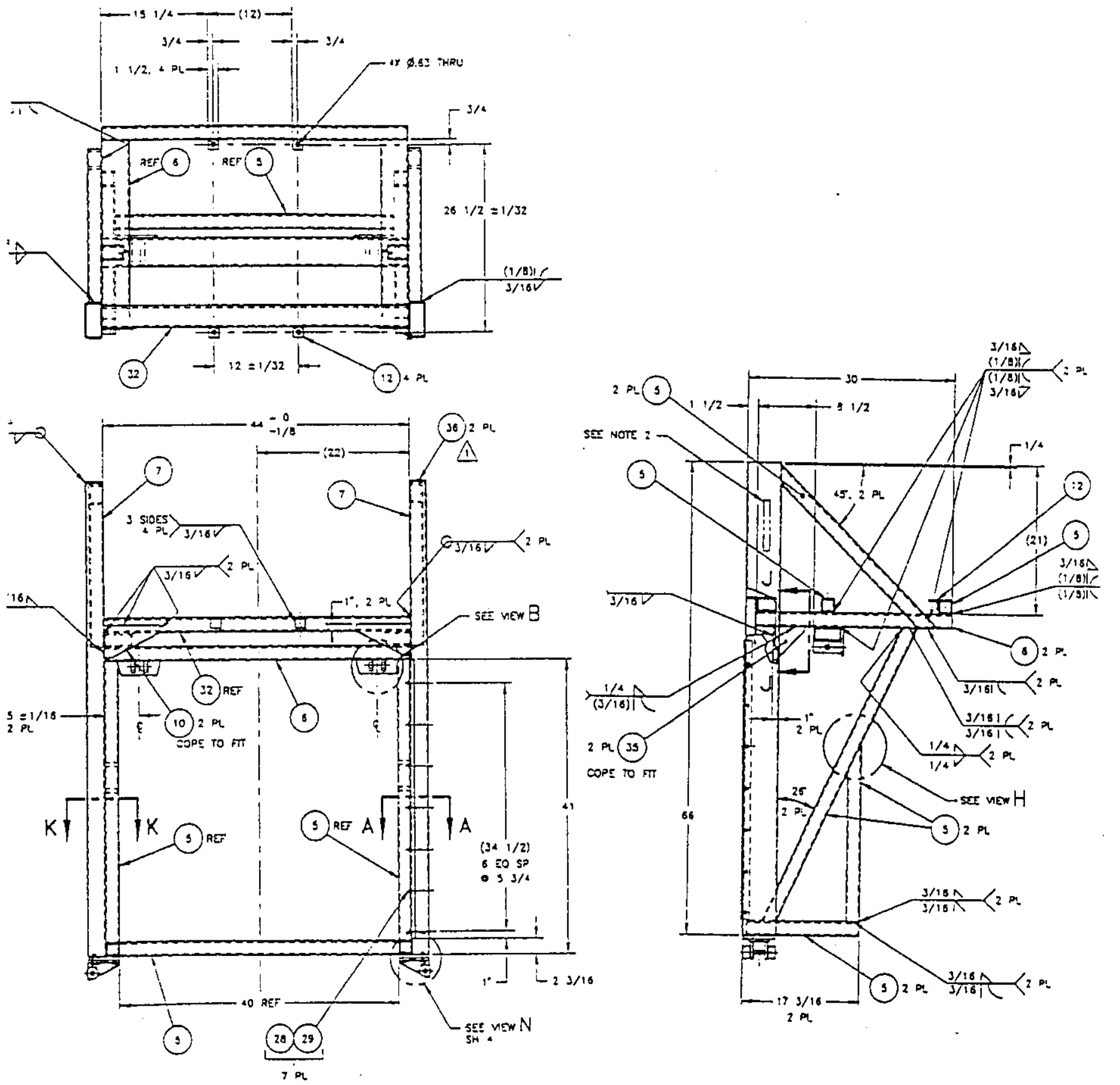
RPP-6018, Rev. 0

FIGURE 3: SHIELDED RECEIVER FIXED SUPPORT FRAME ASSEMBLY
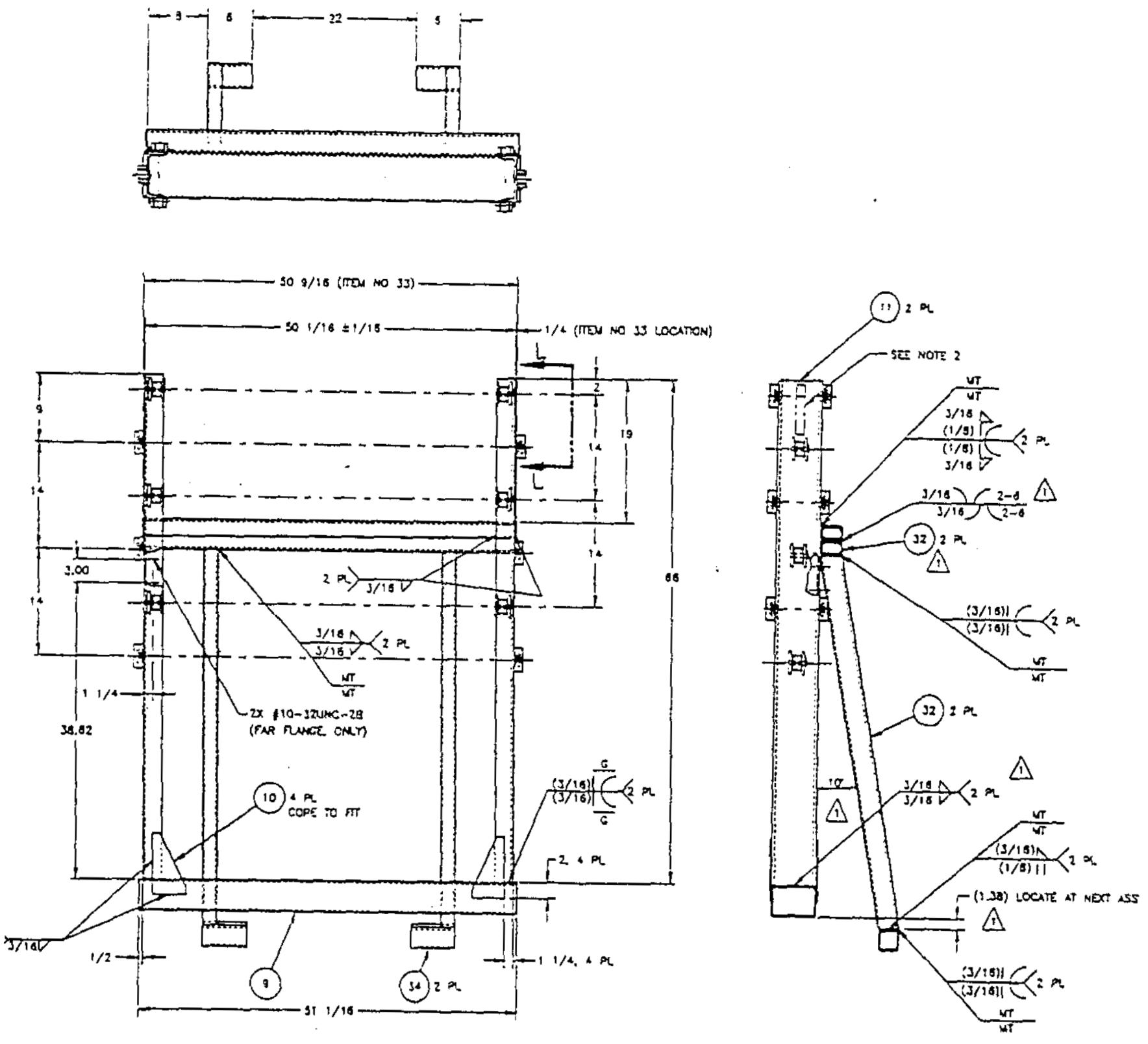
Table 1. Maximum Member Stresses Normal Deadweight Loads

\begin{tabular}{|c|l|c|c|}
\hline Member* & $\begin{array}{c}\text { Type of } \\
\text { Stress }\end{array}$ & $\begin{array}{c}\text { Maximum } \\
\left(1 \mathrm{bf} / \mathrm{in}^{2}\right)\end{array}$ & $\begin{array}{c}\text { Allowable } \\
\left(1 \mathrm{bf} / \mathrm{in} \mathbf{n}^{2}\right)\end{array}$ \\
\hline \hline 40 & Axial & 518 & 21600 \\
\hline 41 & Bending & 7475 & 23760 \\
\hline 107 & Shear & 8019 & 14400 \\
\hline 39 & Combined** & 7970 & 23760 \\
\hline
\end{tabular}

Table 2. Maximum Member Stresses Deadweight Plus Transportation Loads

\begin{tabular}{|c|c|c|c|}
\hline Member* & $\begin{array}{c}\text { Type of } \\
\text { Stress }\end{array}$ & $\begin{array}{c}\text { Maximum } \\
\left(1 \mathrm{bf} / \mathrm{in}^{2}\right)\end{array}$ & $\begin{array}{c}\text { Allowable } \\
\left(1 \mathrm{bf} / \mathrm{in}^{2}\right)\end{array}$ \\
\hline 82 & Axial & 2364 & 21600 \\
\hline 44 & Bending & 18180 & 23760 \\
\hline 16 & Shear & 4708 & 14400 \\
\hline 41 & Combined** & 21300 & 23760 \\
\hline
\end{tabular}

*Beam number from Images-30 Mode1, see Appendix A.

**Mostly bending stress, use bending stress allowable. 
Table 3. Calculated and Allowable Weld Stresses

\begin{tabular}{|c|c|c|c|}
\hline \multirow{2}{*}{$\begin{array}{l}\text { Joining } \\
\text { Members }\end{array}$} & \multicolumn{2}{|c|}{ Calculated Weld Stress (lbf/in) } & \multirow{2}{*}{$\begin{array}{c}\text { Allowable Weld } \\
\text { Stress** } \\
\text { (1bf/in) }\end{array}$} \\
\hline & Deadweight & Transportation & \\
\hline 11 to $9 *$ & 268 & 2091 & 2775 \\
\hline 5 to 5 bracing & 139 & 429 & 2775 \\
\hline 5 to 6 bracing & 635 & 1658 & 2775 \\
\hline 5 to 6 upper bracing & 406 & 861 & 2775 \\
\hline 5 to 6 cross members & 156 & 426 & 2775 \\
\hline 32 to $11 *$ & 136 & 1445 & 2775 \\
\hline 32 to $32 *$ & 81 & 1765 & 2775 \\
\hline 32 to $34 *$ & 119 & 1640 & 2775 \\
\hline 34 to rig* & 118 & 2714 & 2775 \\
\hline 5 to 7 upper bracing & 247 & 327 & 2775 \\
\hline 5 to 6 cross members & 1202 & 2299 & 2775 \\
\hline 6 to 6 ma in cross member & 1976 & 2355 & 2775 \\
\hline $\begin{array}{l}6 \text { to } 7 \\
\text { Gusset to } 10 \\
\end{array}$ & $\begin{array}{l}1036 \\
743 \\
\end{array}$ & $\begin{array}{l}1900 \\
1363 \\
\end{array}$ & $\begin{array}{l}2775 \\
2775 \\
\end{array}$ \\
\hline 32 to 7 end weld & 1273 & 2535 & 2775 \\
\hline 6 to 7 gusset to 35 & 3222 & 4399 & 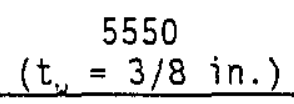 \\
\hline $\begin{array}{l}6 \text { to } 7 \text { weld on side of } \\
\text { members }\end{array}$ & 306 & 1635 & 2775 \\
\hline 5 to 5 lower bracing & 63 & 687 & 2775 \\
\hline $\begin{array}{l}5,5 \text { to } 7 \text { lower bracing } \\
\text { to vertical tube }\end{array}$ & $\begin{array}{l}114 \\
145 \\
\end{array}$ & $\begin{array}{l}713 \\
326 \\
\end{array}$ & $\begin{array}{l}2775 \\
2775 \\
\end{array}$ \\
\hline 5 to 5 lower bracing & 64 & 1425 & 2775 \\
\hline $\begin{array}{l}\text { Actuator support } \\
\left(90^{\circ} \text { joint) }\right.\end{array}$ & 976 & 1133 & $\begin{aligned} & 3700 \\
\left(t_{w}=\right. & 1 / 4 \text { in. })\end{aligned}$ \\
\hline $\begin{array}{l}\text { Actuator support } \\
\text { to C } 5 \times 9\end{array}$ & $\begin{array}{l}3 / 16^{\prime \prime} \text { fillet } \\
\text { equiv reqd }\end{array}$ & $\begin{array}{l}3 / 16^{\prime \prime ~ f i l l e t ~} \\
\text { equiv reqd }\end{array}$ & $\begin{array}{l}3 / 4^{\prime \prime} \text { weld } \\
\text { thickness } \\
\text { available }\end{array}$ \\
\hline
\end{tabular}

*Fixed frame joint

**For fillet weld thickness $\left(t_{w}\right)=3 / 16$ in. unless otherwise specified. 
RPP-6018, Rev. 0

Appendix C: Structural and Stress Analysis, Shielded Receiver Lifting Frame and Jack Assemblies, Core Sample Truck \#3 and \#4 


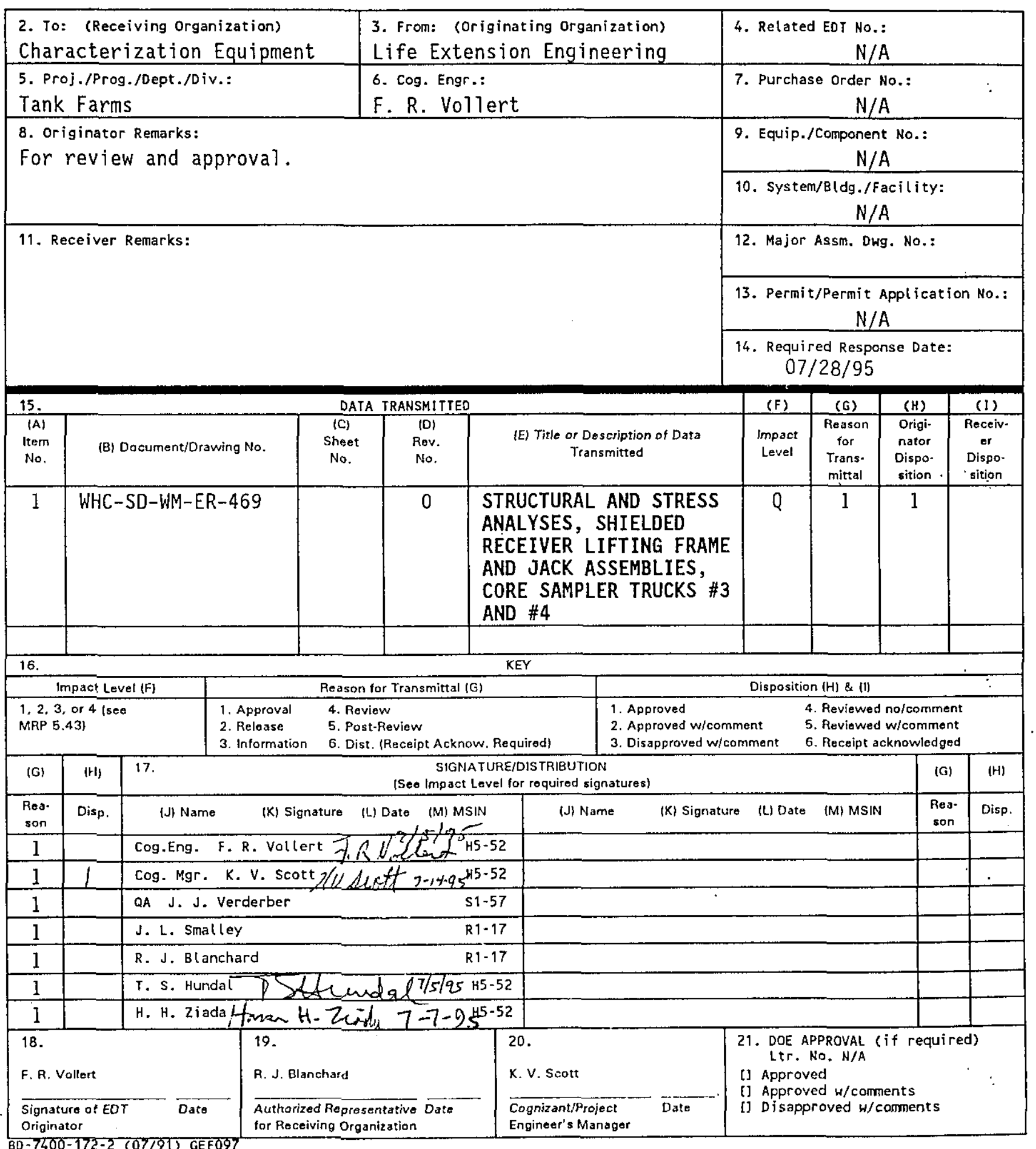




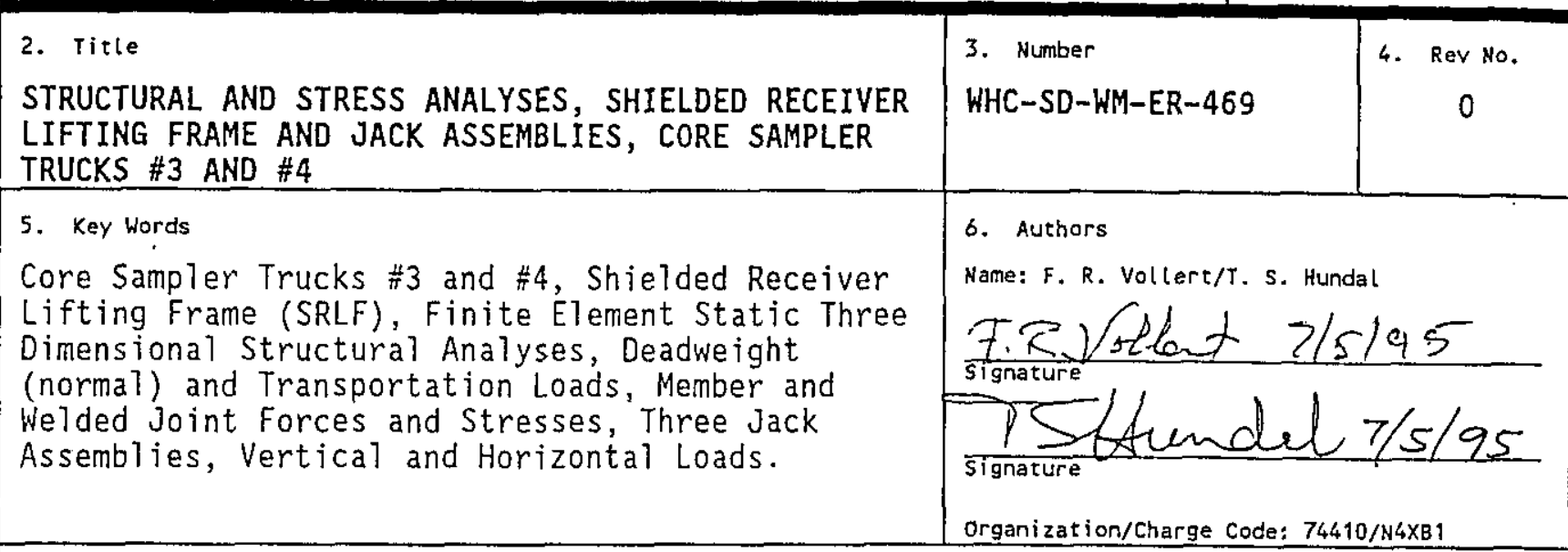

\section{Abstract}

Structural and stress analyses have been completed for the shielded receiver lifting frame (SRLF), and the jack assemblies mounted on core sampler trucks $\# 3$ and $\frac{4}{\pi} 4$.

The SRLF is a space frame structure fabricated from structural steel tubes and channels, with welded joints. Analyses cases were run for the deadweight loads and the deadweight combined with loads representing potential transportation demands. Three dimensional, static finite element analyses were conducted. The analyses results include: the structural member stresses, and the forces in the welded joints. The joint forces were used to calculate the weld stresses. The member and weld stresses were determined to be in conformance with AISC 1989 and AWS 1992. The analyses results, particularly for the welds, do not predict the potential affects of residual stresses, cyclic stress, stress concentrations, and potential defects. Therefore, it is recommended that the welded joints, including the attachments to the truck, be thoroughty cleaned and visually inspected frequently.

The front, center and rear jack assemblies are beam structures connected to the trucks. Stress analyses were conducted for the vertical forces applied by the jacks. Also, horizontal jack forces were considered for the front and rear assemblies. For the vertical loads, the member, weld, and bolt stresses in the load paths to the truck were determined to be in conformance with AISC 1989 and AWS 1992. The assemblies have low capacity for horizontal jack loads. Finally, these assemblies are frequently used lifting fixtures for the trucks and core sampling equipment. They should have frequent, comprehensive preventive maintenance (PM) visual inspections for structural distress. 


\section{CONTENTS}

PAGE

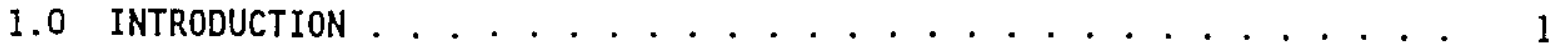

2.0 CONCLUSIONS AND RECOMMENDATIONS $\ldots \ldots \ldots \ldots$

3.0 MATERIALS AND ALLOWABLE STRESSES . . . . . . . . ... 3

3.1 STRUCTURAL STEEL STRENGTH AND ALLOWABLE STRESSES $\ldots \ldots$

3.2 WELD ALLOWABLE STRENGTH . . . . . . . . . . . . 4

3.3 BOLT ALLOWABLE STRESSES . . . . . . . . . . . . 5

4.0 CONFIGURATION AND LOADS . . . . . . . . . . . . . . 5

4.1 SHIELDED RECEIVER Lifting Frames $\ldots \ldots \ldots \ldots$

4.2 JACK ASSEMBLIES . . . . . . . . . . . . . . . 5

5.0 STRUCTURAL ANALYSES AND RESULTS . . . . . . . . . . . 9

5.1 SHIELDED RECEIVER LIFTING FRAME ANALYSES $\ldots \ldots \ldots$

5.2 JACK ASSEMBLY ANALYSES . . . . . . . . . . . . . . . 12

5.2.1 Front Jack Assembly ............... . 12

5.2 .2 Rear Jack Assembly. . . . . . . . . . . . . . 13

5.2.3 Center Jack Assembiy . . . . . . . . . . . . . . . 13

6.0 ROLLOVER STABILITY ANALYSES . . . . . . . . . . . . 14

7.0 REFERENCES . . . . . . . . . . . . . . . 17

APPENDIX A - FINITE BEAM ELEMENT ANALYSES, SHIELDED RECEIVER LIFTING FRAME, CORE SAMPLER TRUCKS \#3 AND \#4

APPENDIX B - STRESS ANALYSES, WELDED JOINTS, SHIELDED RECEIVER LIFTING FRAME, CORE SAMPLER TRUCKS \#3 AND \#4

APPENDIX C - STRESS ANALYSES, JACK ASSEMBLIES, CORE SAMPLER TRUCKS \#3 AND \#4 
RPP-6018, Rev. 0

\section{STRUCTURAL AND STRESS ANALYSES, SHIELDED RECEIVER LIFTING FRAME AND JACK ASSEMBLIES, CORE SAMPLER TRUCKS \#3 AND \#4}

\subsection{INTRODUCTION}

Stress analyses and structural evaluations have been conducted for the shielded receiver lifting frames (SRLF) and the jack assemblies mounted on core sampler trucks number 3 and 4 . The SRLF was analyzed for the normal operational static vertical (deadweight) loads. It was also analyzed to determine the effects of the deadweight loads combined with additional static vertical and horizontal loads intended to account for the potential demands of transporting the SRLF on the truck. The front, center, and rear jack assemblies including their connections or attachments to the trucks were analyzed for vertical forces applied when the jacks are deployed. These analyses also computed the maximum capacities for concurrent horizontal jack forces for the front and rear jack assemblies.

The SRLF is a space frame structure with welded joints (WHC 1995a). It is fabricated from various size structural steel tubes, except the two main members for the fixed frame portion are 6 inch deep channels. The objectives of the structural analyses include determining and evaluating the stresses in the frame members and the weld joints. Three dimensional static finite beam element analyses of the SRLF were conducted (Images 1993). The models used represent the SRLF in the raised and lowered position, and envelope the restraint provided by the welded attachments to the truck. Fully fixed joints were used in the finite element models. The results were member stresses and joint forces. The joint forces were used to calculate the weld stresses for the joints with methods from Blodgett 1982 . The member and weld stresses were evaluated and determined to be in conformance with AISC 1989 and AWS 1992 . However, AISC 1989 and AWS 1992 advise that successfuT welded connections require detailing considerations and precautions for residual welding stresses, load or stress distribution, cyclic stresses, and stress raisers or defects. The SRLF structural member ends are simply and directly welded together. Therefore, the analyses do not predict the potential effects of these factors. To compensate, the SRLF welds including the attachments to the truck should frequentiy be cleaned and visually inspected.

The front jack assembly is a simple beam ( $W 5 \times 16$ ) with a center mounted jack. The center jack assemblies (two per truck) act as cantilever beams ( $W$ $14 \times 22$ ) with concentrated end loads from the jacks. The rear jack assembly is a simple beam ( $W 14 \times 22$ ) supported or lifted by end mounted jacks, with concentrated loads at the two attachment points to the truck chassis

(WHC 1995b). The objectives of the jack assembly analyses were to calculate the stresses for and evaluate all the structural members, joints (e.g., welds and bolts) and connections in the load path from the jacks and bolsters to the truck chassis. Standard design stress analysis methods for structural steel beam type members and their connections were used. The member, bolt, and weld stresses were determined to be in conformance with AISC 1989 and AWS 1992 . The jack assemblies are lifting fixtures for the core sampler trucks, drilling platforms, and the SRLF (with receiver and sample tube). The assembilies will be in frequent use. The front and rear assemblies are potentially stressed near their design allowables in some locations. The assemblies including the 
RPP-6018, Rev. 0

attachments to the trucks should, as preventative maintenance (PM), be thoroughly cleaned and visually inspected frequentiy.

In addition, a roll over evaluation was performed. The results were used to develop the recommended maximum acceptable speed for trucks 3 and 4 .

\subsection{CONCLUSIONS AND RECOMMENDATIONS}

The SRLF structural analyses results are the stresses and joint forces for the structural members. The joint forces were then used to calculate the welded joint stresses, including the stresses in the gusset plates that stiffen four joints. These calculated member and weld stresses all are within the allowable values. The allowable fillet weld stress basis is the shear stress value at its throat. The AISC 1989 and AWS 1992 further advise that successful welded connections require detailing considerations and precautions for residual welding stresses, load or stress distribution, cyclic stresses, and stress raisers or defects. The SRLF structural member ends are simply and directly welded together. Connection hardware and detailing precautions, e.g., clip angles, which balance joint forces, avoid defects and stress raisers, and minimize residual and secondary stresses, were not used. Therefore, the analyses and the results do not predict or incorporate the potential affects of:

Residual stresses due to fabrication (welding)

Cyclic stress changes during operation and transportation (fatigue)

Stress concentrations, sharp corners, and potential defects in the welded joints

The computed stresses in the members and welds would directly superimpose with residual stresses. This increases the potential for over stresses under all load conditions, particularly for the welds. Cyclic stresses have the potential to initiate and propagate fatigue cracks. Again, the welds with the higher likelihood for stress concentrations and defects are the most vulnerable. Comprehensive analyses to account for these potential effects could be conducted. A number of enveloping assumptions would be necessary. It is believed that, after further analyses, too many uncertainties would remain to eliminate this concern.

It is recommended that the weId joints in the SRLF and the attachments to the truck be thoroughly cleaned and visually inspected frequently. For example, inspect after each 30 days of operation, and after each relocation to another tank farm. The inspections would be for evidence of structural and joint distress including cracks. They should be frequent, because visual inspection may not be able to find cracks before they have advanced considerably.

In the event SRLF structural distress occurs where joint repair is necessary, evaluation should be made to determine if the design details can be readily improved. 
For all three jack assemblies subject to the given (WHC 1995c) maximum vertical jack loads only, the calculated member stresses, welds stresses, bolt forces, and bearing loads are within the allowable values and capacities. The jack assemblies are not designed to support horizontal jack loads. Therefore, one recommendation is to post signs on the trucks to warn against allowing side loads on the jacks. Another is that the operating procedures include precautions to prevent the application of any side loads on the jacks.

The front jack maximum vertical 11,100 lbf (WHC 1995c) load alone will develop about $82 \%$ of the allowable shear force capacity in the $5 / 8-i n$. SAE Grade 8 bolts in the connection to the truck chassis. Therefore, about a 450 lbf horizontal concurrent load on the front jack will over stress these bolts in shear.

The rear jack assembly vertical load capacity is governed by the stress in the 3/16-in. fillet welds to the truck chassis. The 10,000 1bf (WHC 1995c) maximum vertical rear jack loads develop $58 \%$ of the allowable stress capacity in these welds. The bolsters on the rear assembly highly limit the capacity for horizontal jack loads. A 500 lbf horizontal rear jack load in the forward or aft longitudinal direction will develop the allowable bending stress capacity in the 1/4-in. thick bolster end plates. A 1,250 lbf horizontal jack load in the left or right Tateral direction will develop the allowable stress in the attachment welds for the jack mounting plates on the bolsters.

The center jack given vertical 10,000 lbf design load (WHC 1995c) would develop $55 \%$ of the allowable stress capacity in the $3 / 16-i n$. fillet welds attaching the end plate to the $W 14 \times 22$ beam. An evaluation of the center jack assembiy for horizontal jack loads was not required.

The jack assemblies are lifting fixtures for the core sampler trucks, drilling platforms, and the SRLF (with receiver and sample tube). The assemblies will be in frequent use. The front and rear assemblies, particularly if subjected to concurrent horizontal jack forces, are potentially stressed near their design allowables in some locations. The assemblies including the attachments to the trucks should, as preventative maintenance $(P M)$, be thoroughly cleaned and visualiy inspected frequently. These should be comparable to the comprehensive inspections (third party) required for cranes and lifting fixtures with potential serious safety consequences due to fajlure, and conducted by qualified personnel. Major structural repair should be evaluated in advance by qualified engineering personnel. Damaged lifting fixtures will often be replaced, because the possible repairs could still leave uncertainties and safety concerns.

The recommended maximum acceptable speed for trucks 3 an 4 on Hanford site paved roads is $15 \mathrm{mi} / \mathrm{h}$. This is the same as determined for truck 2 (WHC 1994a).

\subsection{MATERIALS AND ALLOWABLE STRESSES}

The design drawings (WHC 1995a), (WHC 1995b) for the SRLF and the jack assemblies specify either ASTM A36 or ASTM A500, Grade B steel for the structural tubes and channels. The steel plates and other components used are 
ASTM A36. The weld metal used has a specified minimum ultimate strength of $70,000 \mathrm{lbf} / \mathrm{in}^{2}$. Steel SAE Grade 8 bolts attach the front and center jack assemblies to the trucks. Finaliy, the truck chassis longitudinal steel members have a minimum ultimate tensile strength $\left(F_{u}\right)$ of $.103 \mathrm{Kips} / \mathrm{in}^{2}$.

\subsection{STRUCTURAL STEEL STRENGTH AND ALLOWABLE STRESSES}

The strength, allowable stresses, and other material properties used for a11 the structural steel members and components in the SRLF and jack assemblies were established conservatively from ASTM A36 steel minimum specifications as follows:

$$
\begin{array}{ll}
\text { Modulus of Elasticity, } E & =29,000,000 \mathrm{lbf} / \mathrm{in}^{2} \\
\text { Shear Modulus, } G & =11,200,000 \mathrm{lbf} / \mathrm{in}^{2} \\
\text { Poisons Ratio, } \mu & =0.300 \\
\text { Ultimate Tensile Strength, } F_{u} & =58,000 \mathrm{lbf} / \mathrm{in}^{2} \\
\text { Yield Strength, } F_{y} & =36,000 \mathrm{lbf} / \mathrm{in}^{2} \\
\text { Allowable Tensile Stress, } F_{t} & =0.60 \times F_{y}=21,600 \mathrm{lbf} / \mathrm{in}^{2} \\
\text { Allowable Bending Stress, } F_{b} & =0.66 \times F_{y}=23,760 \mathrm{lbf} / \mathrm{in}^{2} \\
\text { Allowable Shear Stress, } F_{v} & =0.40 \times F_{y}=14,400 \mathrm{lbf} / \mathrm{in}^{2}
\end{array}
$$

\subsection{WELD ALLOWABLE STRENGTH}

The ultimate and allowable strength for the welds joining the SRLF and jack assembly structural members were established in accordance with the Structural Welding Code (AWS 1992), and the Manual of Steel Construction (AISC 1989). These force per unit length values are determined based on the minimum ultimate strength $\left(F_{u w m}\right)$ of the weld metal, and the thickness $\left(t_{w}\right)$ of the weld as follows:

Weld Metal Ultimate Strength, $F_{u w m}=70,0001 \mathrm{bf} / \mathrm{in}^{2}$

Fillet Weld Ultimate Strength, $F_{\text {uw }}=0.707 \times \mathrm{t}_{w} \times F_{\text {uwm }} 1 \mathrm{bf} / \mathrm{in}$

Fillet Weld Allowable Strength, $F_{w}=0.30 \times F_{u w}=14,800 \times t_{w} 1 \mathrm{bf} /$ in 
RPP-6018, Rev. 0

\subsection{BOLT ALLOWABLE STRESSES}

Steel structural bolts, SAE Grade 8 (equivalent to ASTM A490), are used to attach the front and center jack assemblies to the core sampler trucks 3 and 4 . The front assembly bolted connections to the chassis are bearing (shear) type. The allowable shear stress in these bolts is $28,0001 \mathrm{bf} / \mathrm{in}^{2}$. The fixed end supports for the center jack assemblies are provided by end plates bolted to the truck frames. The fixed end moments when the center jacks are deployed will put these bolts in tension. The allowable tension stress in these bolts is $54,000 \mathrm{lbf} / \mathrm{in}^{2}$. The allowable bolt bearing stress in the truck chassis members (1/4-in. thickness) is $1.5 \times F_{4}$, or $1.5 \times 103$ Kips $/ \mathrm{in}^{2}=154 \mathrm{Kips} / \mathrm{in}^{2}$.

\subsection{CONFIGURATION AND LOADS}

\subsection{SHIELDED RECEIVER LIFTING FRAMES}

The configuration of the SRLF structure for core sampler trucks 3 and 4 obtained from the design drawings $\mathrm{H}-2-690043$ and $\mathrm{H}-2-690044$ (WHC 1995a) is shown in Figures 1, 2, and 3 . It is a space frame structure with welded joints. It is fabricated from various size structural steel tubes, except the two main members for the fixed frame portion are 6 inch deep channels. The fixed frame and its two bracing members are welded to the truck. The moveable portion is raised and lowered during normal operation by the two vertical actuators. Figure 1 also shows the location of the normal operation vertical static (deadweight) loads on the moveable portion of the structure. These loads (maximum) are: the sampler hoist shielded receiver box and base plate $(2,100 \mathrm{lbf})$, plus the sampler tube (900 Jbf).

The maximum allowable speed on paved roadways is $15 \mathrm{mi} / \mathrm{h}$ for the core sampler trucks 3 and 4 . This 7 imit was established to prevent truck rollover from the results of a previous analysis for core sampler truck 2 (WHC 1994a). The potential demands of transporting the SRLF on the truck at the $15 \mathrm{mi} / \mathrm{h}$ maximum allowed speed, also estimated by the rollover analysis for truck 2 (WHC 1994a), are represented as additional static forces on the SRLF. These are: $0.18 \mathrm{~g}$ vertical, $0.43 \mathrm{~g}$ longitudinal, and $0.37 \mathrm{~g}$ lateral (see Section 6.0). The moveable portion of the SRLF is in the lowered position during transport.

\subsection{JACK ASSEMBLIES}

The configurations of the front, center, and rear jack assemblies and their connections to core sample trucks 3 and 4 are shown by the design drawings (WHC 1995b). Configuration sketches are also included with the stress analyses in Appendix $C$. The front and rear assemblies are simple beams with bolted and welded connections, respectively, to the truck chass is. The center assemblies are cantilever beams bolted to the truck frames. Vertical static loads are applied to the assemblies when the jacks are deployed to 1 ift or support the core sample trucks during operation. 
Figure 1. Shielded Receiver Lifting Frame Assembiy.

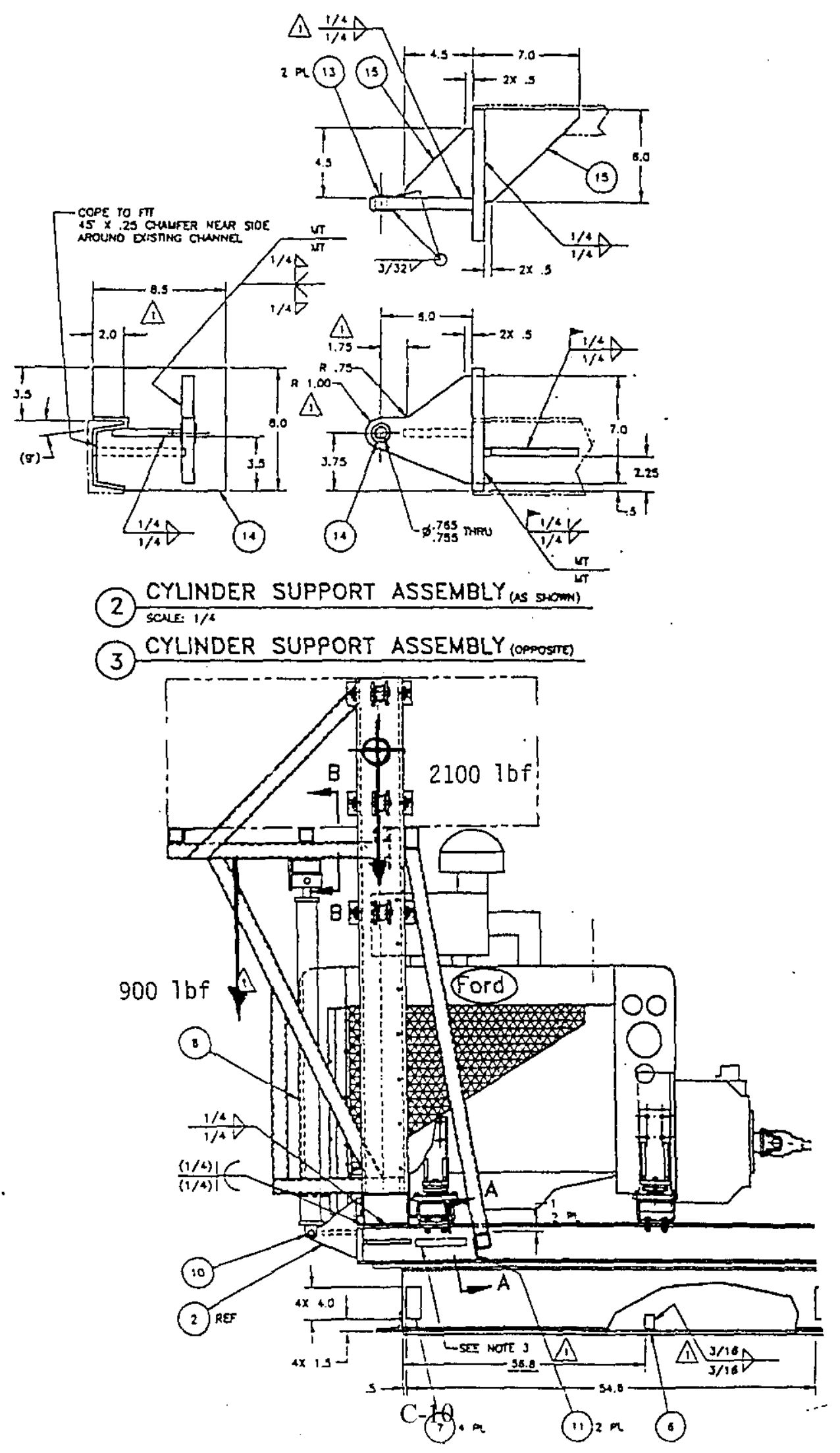


Figure 2. Shielded Receiver Support Frame Assembly.

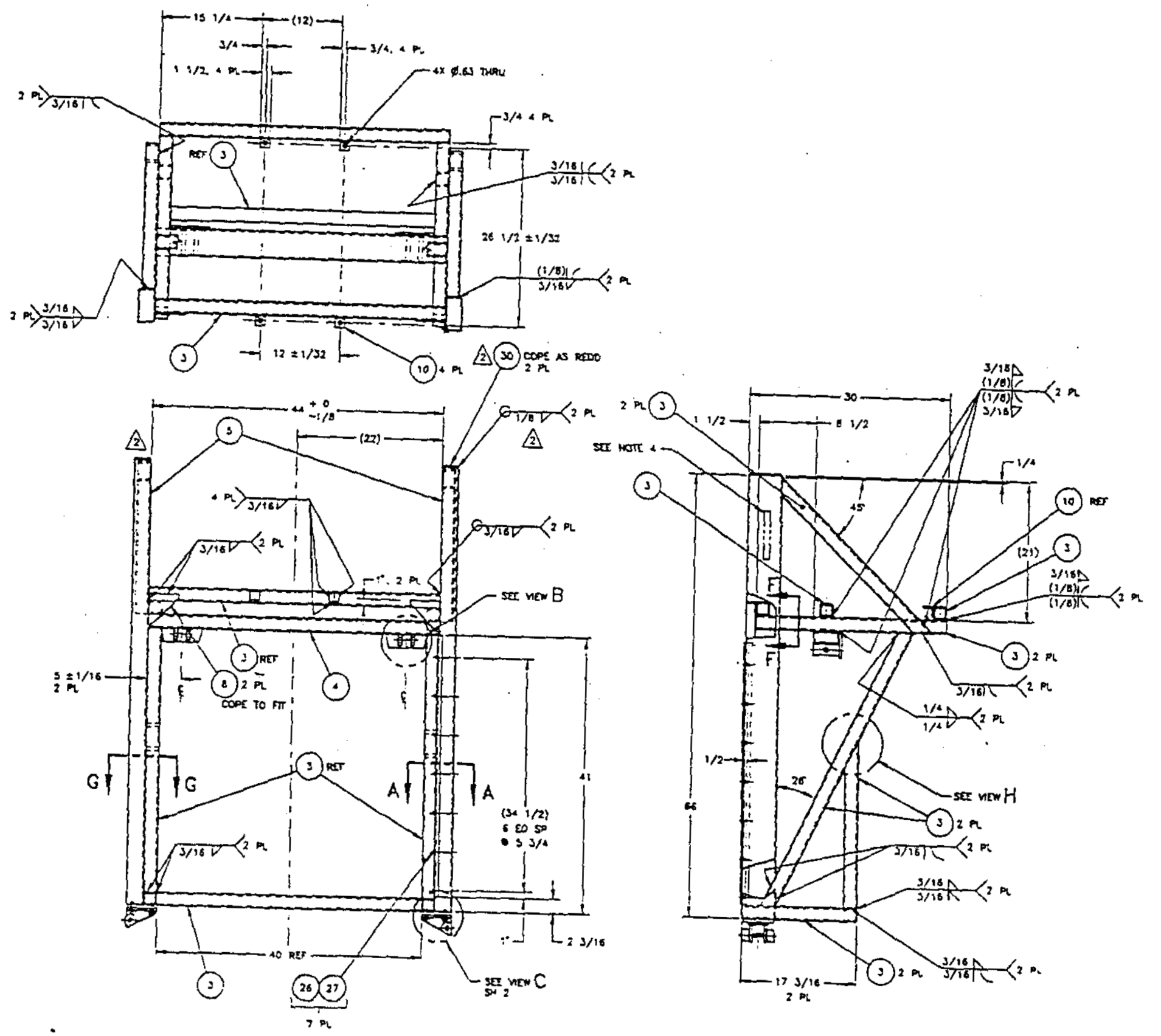


Figure 3. Shielded Receiver Fixed Support Frame Assembly.
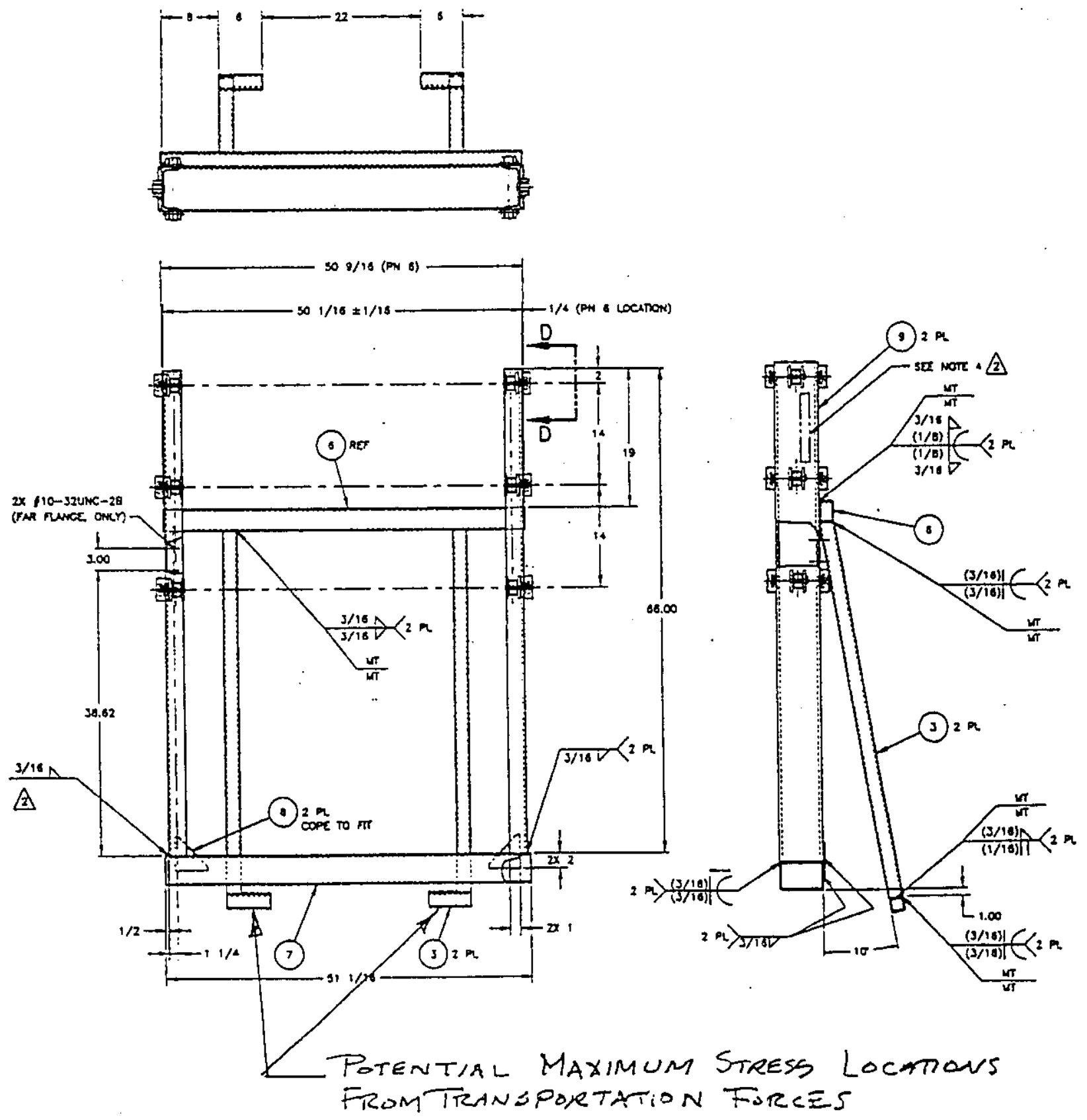
RPP-6018, Rev. 0

The front assembiy maximum vertical load on the single center mounted jack is 11,100 1bf. The rear assembly maximum vertical load on each end mounted jack is 10,000 lbf. The maximum capacities for concurrent horizonta] jack forces for the front and rear jacks were calculated. The center assemblies were analyzed for a 10,000 1 bf vertical (upward) jack or end design load only (WHC 1995C).

\subsection{STRUCTURAL ANALYSES AND RESULTS}

\section{1 SHIELDED RECEIVER LIFTING FRAME ANALYSES}

Three dimensional finite element static analyses were conducted for the SRLF structure (Images 1993) for the normal operation deadweight loads, and for deadweight combined with the additional transportation loads. Finite beam element models with the SRLF in the raised and lowered position were developed and used. Also, the fixed frame was modeled two ways: to be fully restrained at all welds to the truck, and with only the two braces providing the overturning restraint. Fully fixed joints were used in the finite element models, because the SRLF structural member ends are simply and directly welded together at the joints or connections. Four of the SRLF connections are stiffened with gusset plates.

Four deadweight loads analyses cases were run. This was necessary to obtain results for the SRLF in both the raised and lowered position, and for the two restraint conditions assumed for the fixed frame. Four transportation load cases were run with the SRLF in the lowered position. This was necessary to obtain results for both forward and aft direction longitudinal loads, and for the two restraint conditions assumed for the fixed frame. The finite beam element models are described in detail, and all the Images 1993 analyses results are provided in Appendix $A$.

The Images 1993 results include the forces and moments in the members and joints, and the member stresses. The bending, axial, shear, and combined stresses are calculated for each beam element in the SRLF model. The maximum bending, shear, and combined stress values in the SRLF members for deadweight loads, and the transportation loads are listed and compared to the allowables in Table 1 and Table 2, respectively. All of the calculated potential stresses in SRLF structural members are within the allowable.

The stresses in the weld joints due to the member/joint forces and moments were calculated. Weld stress analysis methods from Blodgett 1982 were used. The weld joint stress calculations and evaluations are provided in Appendix B. Table 3 Tists the maximum potential weld stresses for the normal deadweight loads, and transportation loads. For comparison, the allowable weld strengths for the welds are also listed in Table 3 . All of the calculated potential weld stresses in the SRLF joints are within the allowable strengths. For the normal deadweight loads the calculated weld stresses, with few exceptions, are very low. For the additional transportation loads, most of the calculated weld stresses increase significantly. Three of the weld joint stresses essentially equal their allowable strength. Several others are : within $20 \%$ of the allowable strength. 
RPP-6018, Rev. 0

Table 1. Maximum SRLF Member Stresses, Normal Deadweight Loads.

\begin{tabular}{|c|c|c|}
\hline $\begin{array}{l}\text { Type of } \\
\text { Stress }\end{array}$ & $\begin{array}{c}\text { Maximum } \\
\left(1 \mathrm{bf} / \text { in }^{2}\right) \\
\end{array}$ & $\begin{array}{l}\text { Allowable } \\
\left(1 \mathrm{bf} / \mathrm{in}^{2}\right)\end{array}$ \\
\hline Bending ${ }^{(1)}$ & 9,274 & 23,760 \\
\hline Shear (2) & 2,185 & 14,400 \\
\hline Combined ${ }^{(1)}$ & 9,618 & 23,760 \\
\hline
\end{tabular}

(1) Maximum deadweight bending and combined stresses in the aft $2 \times 2 \times 1 / 4$ tube cross member supporting the shielded receiver.

(2) Maximum deadweight shear stress in the $4 \times 2 \times 1 / 4$ tube main cross member.

Table 2. Maximum SRLF Member Stresses, Deadweight Pius Transportation Loads.

\begin{tabular}{|l|c|c|}
\hline $\begin{array}{c}\text { Type of } \\
\text { Stress }\end{array}$ & $\begin{array}{c}\text { Maximum } \\
\left(1 \mathrm{bf} / \mathrm{in}^{2}\right)\end{array}$ & $\begin{array}{c}\text { Allowable } \\
\left(1 \mathrm{bf} / \mathrm{in}^{2}\right)\end{array}$ \\
\hline \hline Bending & 22,080 & 23,760 \\
\hline Shear & 3,975 & 14,400 \\
\hline Combined & 23,740 & 23,760 \\
\hline
\end{tabular}

Note: A11 maximum transportation load stresses in the $2 \times 2 \times 1 / 4$ tube members connecting the fixed frame to the truck frame. 
Table 3. Calculated and Allowable SRLF Weld Stresses.

\begin{tabular}{|c|c|c|c|}
\hline \multirow{2}{*}{$\begin{array}{l}\text { Joining } \\
\text { Members }\end{array}$} & \multicolumn{2}{|c|}{$\begin{array}{c}\text { Calculated Weld } \\
\text { Stress (1bf/in) }\end{array}$} & \multirow{2}{*}{$\begin{array}{c}\text { Allowable } \\
\text { Weld Stress } \\
\text { (1bf/in) }\end{array}$} \\
\hline & Dead Weight & Transportation & \\
\hline $\begin{array}{l}3 \text { and } 3 \text { to } 5 \text { with gusset } \\
\text { plates ( } 3 \text { joints) }\end{array}$ & $\begin{array}{l}1738 \\
814 \\
990 \\
\end{array}$ & $\begin{array}{l}2387 \\
2251 \\
2525 \\
\end{array}$ & $\begin{array}{l}2775 \\
2775 \\
2775 \\
\end{array}$ \\
\hline 4 to 3 main cross member & 744 & 969 & 2775 \\
\hline $\begin{array}{l}3 \text { to } 3 \text { middle horizontal } \\
\text { member }\end{array}$ & 264 & 1978 & 2775 \\
\hline 3 to 3 edge horizontal member & 282 & 857 & 2546 \\
\hline 3 to 5 top brace to vertical & 295 & 447 & 2775 \\
\hline $\begin{array}{l}3 \text { to } 3 \text { top brace to } \\
\text { horizontal }\end{array}$ & 280 & $4 i 3$ & 2775 \\
\hline $\begin{array}{l}3 \text { to } 3 \text { vertical to lower } \\
\text { brace }\end{array}$ & 100 & 236 & 2775 \\
\hline $\begin{array}{l}3 \text { to } 3 \text { lower brace to } \\
\text { horizontal }\end{array}$ & 376 & 948 & 2775 \\
\hline $\begin{array}{l}3 \text { to } 3 \text { bottom of vertical } \\
\text { brace }\end{array}$ & 66 & 531 & 2775 \\
\hline $\begin{array}{l}3 \text { to } 3 \text { bottom of horizontal } \\
\text { brace }\end{array}$ & 103 & 1068 & 2775 \\
\hline 3 and 3 to 5 ( 3 joints) & $\begin{array}{l}150 \\
75 \\
125 \\
\end{array}$ & $\begin{array}{r}446 \\
654 \\
48 \\
\end{array}$ & $\begin{array}{l}2775 \\
2775 \\
2775 \\
\end{array}$ \\
\hline 6 to $9 *$ & 80 & 1584 & 2775 \\
\hline $9+07^{*}$ & 199 & 4881 & 5550 \\
\hline 7 to $C 5 \times 9 *$ (on $r i g$ ) & 195 & 2589 & $2 \pi / 5$ \\
\hline 3 to $6^{*}$ top of diagonal brace & 173 & 2278 & 2775 \\
\hline $\begin{array}{l}3 \text { to 3* bottom of diagonal } \\
\text { brace }\end{array}$ & 144 & 2336 & 2775 \\
\hline 3 to rig* with gusset plates & 237 & 2762 & 2775 \\
\hline Actuator support $\left(90^{\circ}\right.$ joint $)$ & 647 & 1023 & 3700 \\
\hline $\begin{array}{l}\text { Actuator support to c } 5 \times 9 \\
\text { (on rig) }\end{array}$ & $\begin{array}{l}3 / 16 " \text { fillet } \\
\text { equivalent required }\end{array}$ & $\begin{array}{l}3 / 16^{\prime \prime} \text { fillet } \\
\text { equivalent required }\end{array}$ & $\begin{array}{l}1 / 2^{11} \text { weld } \\
\text { thickness } \\
\text { available }\end{array}$ \\
\hline
\end{tabular}

*Fixed Frame Joint 
It was also necessary to use member/joint forces to calculate the bending stresses in the gusset plates that stiffen four joints in the SRLF. The maximum calculated bending stresses in the plates for the deadweight and transportation load cases are $6,992 \mathrm{lbf} / \mathrm{in}^{2}$ and $10,413 \mathrm{ibf} / \mathrm{in}^{2}$, respectively. These are within the $23,760 \mathrm{lbf} / \mathrm{in}^{2}$ allowable bending stress.

\subsection{JACK ASSEMBLY ANALYSES}

The general scope of the jack assembly analyses was to calculate the stresses for the structural members and joints in the load path from the jack mounting plates and bolsters to the truck chassis. The front, center, and rear jack assemblies including their connections or attachments to the trucks were analyzed for vertical forces applied when the jacks are deployed. These analyses also presumed concurrent horizontal jack forces for the front and rear jack assemblies. The calculations for all three assemblies are provided in Appendix C.

\subsubsection{Front Jack Assembly}

The front jack assembly is a simple beam ( $W 5 \times 16)$ with a single center mounted jack. On each end it is connected to the front ends of the truck chassis longitudinal members. These two connections (or pair) are 5-in. deep brackets fabricated from 3/4-in. plate. They are welded to the ends of the jack assembly, and attached to the chassis with 5/8-in. SAE Grade 8 bolts. The analyses were conducted for the maximum vertical front jack load, $11,100 \mathrm{lbf}$, and continued to estimate the capacity of the assembly for concurrent longitudinal and lateral jack loads.

For the 11,100 lbf vertical load only on the front jack, the analyses results are:

The maximum shear force in the $5 / 8-i n$. bolts is $7,088 \mathrm{lbf}$. This is about $82 \%$ of the allowable $8,6001 \mathrm{bf}$.

The bending stress in the main $W 5 \times 16$ beam is $11,1491 \mathrm{bf} / \mathrm{in}^{2}$ maximum, compared to $23,760 \mathrm{lbf} / \mathrm{in}^{2}$ allowable.

The bending and shear stresses in the bracket connections to the truck chassis are $10,451 \mathrm{lbf} / \mathrm{in}^{2}$ and $3,061 \mathrm{lbf} / \mathrm{in}^{2}$, respectively. These values are within their allowables, 23,760 $\mathrm{lbf} / \mathrm{in}^{2}$ bending stress and $14,400 \mathrm{Tbf} / \mathrm{in}^{2}$ shear stress.

The stress in the 1/4-in. fillet welds attaching the brackets to the ends of the W $5 \times 16$ main beam is $336 \mathrm{Tbf} / \mathrm{in}$, well within the $3,700 \mathrm{lbf} /$ in allowable.

The bearing stress from the bolts at the holes in the truck chassis members is $45.4 \mathrm{Kips} / \mathrm{in}^{2}$. The allowable is $154 \mathrm{Kips} / \mathrm{in}^{2}$.

The bearing load capacity for the 7 -in. wide jack mounting plate, based on the $W 14 \times 22$ web crippling potential, is 47.25 Kips. This is very sufficient for the 11.1 Kips maximum vertical jack load. 
The shear forces in the 5/8-in. bolts attaching the front jack assembly to the chassis are at $82 \%$ allowable due to the 11,100 lbf maximum vertical jack load. Therefore, about a 450 lbf horizontal concurrent load on the jack over stresses these bolts.

\subsubsection{Rear Jack Assembly}

The rear jack assembly is a simple beam ( $W 14 \times 22$ ) supported (or lifted) by end mounted jacks, with concentrated loads at the two attachment points to the truck chassis. The attachments to the chassis are $1 / 4$ in thick steel bracket plates welded to the flanges and web on the inside of the $W 14 \times 22$ beam, and to one side of the chassis longitudinal members. The maximum vertical load on each rear jack is 10,000 lbf. It was also necessary to evaluate the horizontal jack load limits for this assembly.

For the 10,000 lbf maximum vertical rear jack load, the stress analyses results for this assembly are:

The maximum stress in the $3 / 16-i n$. fillet welds to the truck chassis is $1,610 \mathrm{lbf} /$ in which is $58 \%$ of the allowable $2,775 \mathrm{lbf} / \mathrm{in}$.

The maximum bending stress in the $W 14 \times 22$ beam is 5,600 $1 \mathrm{bf} / \mathrm{in}^{2}$, compared to $23,7601 \mathrm{bf} / \mathrm{in}^{2}$ allowable.

The bearing load capacity, based on web crippling potential, for the bolsters supporting the jacks is 37 Kips. This is very sufficient for the 10 Kips maximum vertical jack load.

The bolsters on the rear jack assembly highly limit the capacity for horizontal jack loads. The design is very similar to the rear jack assembly for core sampler truck number 2. Therefore, the analyses and results for that assembly for horizontal loads apply (WHC 1994b). A 500 lbf horizontal jack load in the forward or aft longitudinal direction will develop the bending stress capacity in the 1/4-in. thick bolster end plates. A 1,250 lbf left or right lateral load will develop the stress capacity in the attachment we1ds for the jack mounting plates on the bolsters. The other components potentially over stressed by horizontal jack loads exceeding these values are: the main $W 14 \times 22$ beam, both in bending and torsional shear, the mounting bolts for the jacks to the bolsters, and the attachment welds to the truck chassis.

\subsubsection{Center Jack Assembly}

The center jack assemblies (two per truck) act as cantilever beams (W 14x22) with concentrated end loads from the jacks. The fixed end supports are provided by the $3 / 4-i n$. thick end plates, welded to the end of the beam and bolted (1-in. and 3/4-in. SAE Grade 8 bolts) to the lower frames of the core sampler trucks. The assembly was analyzed for a 10,000 lbf vertical (upward) jack or end load. The analysis results are:

The bending stress in the $\mathrm{W} 14 \times 22$ beam is $10,600 \mathrm{lbf} / \mathrm{in}^{2}$ maximum, the a) lowable is $23,760 \mathrm{lbf} / \mathrm{in}^{2}$. 
The maximum tension forces in the $1-i n$. and $3 / 4-i n$. bolts attaching the end plates to the truck are $9.3 \mathrm{Kips}$ and $1.9 \mathrm{Kips}$, versus the $42.4 \mathrm{Kips}$ and 23.9 Kips respective allowables.

The maximum stress in the cantilever beam end plate $3 / 16-i n$. fillet weld is $1,533 \mathrm{Tbf} /$ in which is $55 \%$ of the allowable $2,775 \mathrm{lbf} / \mathrm{in}$.

The bearing load capacity, based on web crippling potential, for the bolster supporting the jack is 37 Kips. This is very sufficient for the I0 Kips maximum vertical jack load.

\subsection{ROLLOVER STABILITY ANALYSES}

The WHC 1994a rollover stability analys is for core sample truck number 2 which estimates the acceptable $15 \mathrm{mi} / \mathrm{h}$ limiting speed on Hanford site paved roads applies to trucks 3 and 4 . The potential transportation acceleration loads at $15 \mathrm{mi} / \mathrm{h}$ will also be the same as for truck $2,0.43 \mathrm{~g}$ longitudinal, $0.37 \mathrm{~g} l$ ateral, and $0.18 \mathrm{~g}$ vertical. Another analysis was required to estimate the minimum turning radij versus speed for differing roadway bank (super elevation) angles for trucks 3 and 4 . Less restrictive turning radii are theoretically required for trucks 3 and 4 .

The recommended $15 \mathrm{mi} / \mathrm{h}$ maximum speed for truck 2 (WHC 1994a) is governed by the center of gravity $(\mathrm{cg})$ height for the truck with the drilling platform and its equipment. For truck 2 the $\mathrm{cg}$ height is 64.3 inches (WHC 1994a). For trucks 3 and 4 it is 60.0 inches, see Table 4 , Weight Distributions for Core Sample Trucks 3 and 4 (WHC 1995c). To allow the speed limit for trucks 3 and 4 to increase by $1 \mathrm{mi} / \mathrm{h}$ to $16 \mathrm{mi} / \mathrm{h}$, the $\mathrm{cg}$ height would have to be 57.0 inches or lower. This would increase the transportation loads by about $10 \%$, which could affect the structural design for the SRLF. Therefore, the recommended maximum acceptable speed for trucks 3 and 4 on paved roads remains at $15 \mathrm{mi} / \mathrm{h}$.

The WHC 1994a minimum turning radii analysis for truck 2 was repeated for trucks 3 and 4 . Table 5 has the results, and the comparable results for truck 2 from WHC 1994a. Shorter turning radii are theoretically required for trucks 3 and 4 for given speeds and bank angles due to its lower $\mathrm{cg}$. For both. cases, about a 0.7 coefficient of friction is required to prevent skidding during minimum radii turns. 
RPP-6018, Rev. 0

Table 4. Weight Distribution, Core Sample Trucks Number $3 \& 4$.

\begin{tabular}{|l|c|c|c|}
\hline & $\begin{array}{c}\text { Longitudinal, } x^{(1)} \\
\text { (in) }\end{array}$ & $\begin{array}{c}\text { Lateral, } y^{(1)} \\
\text { (in) }\end{array}$ & Vertical, $z^{(2)}$ \\
\hline \hline Truck Chasis & 120 & 0 & 21 \\
\hline Total & 49 & 0 & 60 \\
\hline
\end{tabular}

(1) Distance from veritical centerline of rotatiing platform, $+x$ towards $c a b$, and $+y$ towards driver side.

(2) Distance from ground level, +z up. 
Table 5. Theorectical Minimum Turn Radi i Core Sample Trucks.

\begin{tabular}{|c|c|c|c|c|}
\hline $\begin{array}{l}\text { Truck } \\
\text { Speed } \\
\text { (mi /h) } \\
\end{array}$ & $\begin{array}{l}\text { Bank } \\
\text { Angle } \\
\text { (deg) } \\
\end{array}$ & $\begin{array}{l}\text { Minimum } \\
\text { Turn Radius } \\
\text { (ft) }\end{array}$ & $\begin{array}{c}\text { With } 0.37 \mathrm{~g} \text { Force } \\
\text { Minimum Turn Radius(1) } \\
\text { (ft) }\end{array}$ & $\begin{array}{c}\text { Coef } \\
\text { Friction } \\
\text { Req'd (2) } \\
\end{array}$ \\
\hline \multirow{3}{*}{15} & -10 & 33 & 165 & 0.69 \\
\hline & -3 & 24 & 60 & 0.69 \\
\hline & 0 & 22 & 46 & 0.69 \\
\hline \multirow{3}{*}{12} & -10 & 21 & 105 & 0.69 \\
\hline & -3 & 16 & 38 & 0.69 \\
\hline & 0 & 14 & 30 & 0.69 \\
\hline \multirow{3}{*}{9} & -10 & 12 & 59 & 0.69 \\
\hline & -3 & 9 & 22 & 0.69 \\
\hline & 0 & 8 & 17 & 0.69 \\
\hline
\end{tabular}

\begin{tabular}{|c|c|c|c|c|}
\hline \multicolumn{5}{|c|}{ Truck 2 with $B=10^{\circ}$ Body Roll } \\
\hline $\begin{array}{l}\text { Truck } \\
\text { Speed } \\
(\mathrm{mi} / \mathrm{h}) \\
\end{array}$ & $\begin{array}{r}\text { Bank } \\
\text { Angle } \\
\text { (deg) } \\
\end{array}$ & $\begin{array}{l}\text { Minimum } \\
\text { Turn Radius } \\
\text { (ft) } \\
\end{array}$ & $\begin{array}{c}\text { With } 0.37 \text { g Force } \\
\text { Minimum Turn Radius } \\
(\mathrm{ft})\end{array}$ & $\begin{array}{c}\text { Coef } \\
\text { Friction } \\
\text { Req'd } \\
\end{array}$ \\
\hline \multirow{3}{*}{15} & -10 & 35 & 242 & 0.66 \\
\hline & -3 & 26 & 70 & 0.66 \\
\hline & 0 & 23 & 52 & 0.66 \\
\hline \multirow{3}{*}{12} & -10 & 22 & 155 & 0.66 \\
\hline & -3 & 16 & 45 & 0.66 \\
\hline & 0 & 15 & 33 & 0.66 \\
\hline \multirow{3}{*}{9} & -10 & 13 & 87 & 0.66 \\
\hline & -3 & 9 & 25 & 0.66 \\
\hline & 0 & 8 & 19 & 0.66 \\
\hline
\end{tabular}

${ }^{1}$ Minimum radius of turn without rollover.

${ }^{2}$ Minimum required coefficient of static friction between tires and roadway for no skidding. 


\subsection{REFERENCES}

AISC, 1989, Manual of Steel Construction, Allowable Stress Design, Ninth Edition, American Institute of Steel Construction, Chicago, Illinois.

ASTM, 1989, Annua7 Book of ASTM Standards, American Society for Testing and Materials, Philadelphia, Pennsylvania.

AWS, 1992, Structural Welding Code-Steel, ANSI/AWS D1.1-92, American Welding Society, Miami, Florida

BTodgett, 0. W., 1982, Design of Welded structures, James F. Lincoln Arc Welding Foundation, Cleveland, Ohio

Images, 1993, Interactive Microcomputer Analysis and Graphics of Engineering Systems, IMAGES-3D, Version 3.0, Celestial Software, Inc., Berkeley, CaTifornia.

WHC, 1994a, Rollover Analysis of Rotary Mode Core Sampler Truck \#2, WHC-SD-WM-ER-391, Rev. 0, Westinghouse Hanford Company, Richland, Washington.

WHC, 1994b, Stress analysis of Jacks, Frame, and Bearing Connections and Drill. Rod For Core Sampler Truck \#2, WHC-SD-WM-ER-392, Rev 0, Westinghouse Hanford Company, Richland, Washington.

WHC, 1995a, Shielded Receiver Lifting Frame Assembly, Core Sample Truck, Drawing Numbers $\mathrm{H}-2-690043$ and $\mathrm{H}-2-690044$, Westinghouse Hanford Company, Richland, Washington.

WHC, 1995b, Rear, Center, and Front Jack Assemblies, Drawing Numbers H-2$690010, \mathrm{H}-2-690011, \mathrm{H}-2-690017$, and $\mathrm{H}-2-690106-1$, Westinghouse Hanford Company, Richland, Washington.

WHC, 1995c, Internal Memo, J. L. Smalley to H. H. Ziada, Estimates of Actual Loads For The Rotary Mode Core Sample Trucks \#3 and \#4, Westinghouse Hanford Company, Richland, Washington. 
RPP-6018, Rev. 0

APPENDIX A

\author{
FINITE BEAM ELEMENT ANALYSES \\ SHUELDED RECEIVER LIFTING FRAMIE
}

CORE SAMPLER TRUCKS \#3\& 4

A-1

C-22 


\section{INDEPENDENT REVIEW CHECKLIST}

\section{Document Reviewed Einite Element_Analyses of Shielded Receiver Lifting Frame for Core Sampler Trucks No. 3\&\& 4}

Author T_S_Hundal

Document No. WHHC-SD-WM-ER_ 46 \%Rev 0

Yes No NLA.

[s] [ ] [ ] Problem completely defined.

[X] [ ] [ ] Necessary assumptions explicitly stated and supported.

[X] [ ] [ ] Computer codes and data files documented.

[- ] [ ] [ ] Data used in calculations explicitiy stated in document.

[X] [ ] [ ] Data checked for consistency with original source information as applicable.

X] [ ] [ ] Mathematical derivations checked including dimensional consistency of results.

[X] [ ] [ ] Models appropriate and used within range of validity or use outside . range of established validity justified.

[X] [ ] [ ] Hand calculations checked for errors.

[Y] [ ] [ ] Code run streams correct and consistent with analysis documentation.

[X] [ ] [ ] Code output consistent with input and with results reported in analysis documentation.

[ ] [ ] [X] Acceptability limits on analytical results applicable and supported. Limits checked against sources.

[ ] [ ] [X] . Safety margins consistent with good engineering practices.

[X] [ ] [ ] Conclusions consistent with analytical results and applicable limits.

[D] [ ] [ ] Results and conclusions address all points required in the problem statement.

MANDATORY Software QA Log Number FRY-45-019

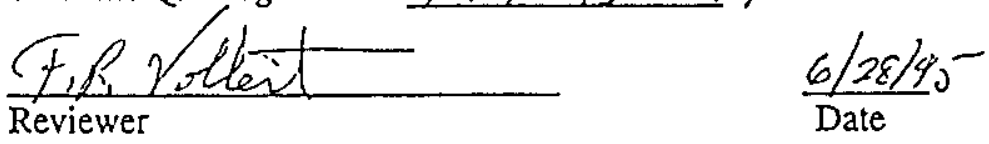


RPP-6018, Rev. 0

CONTENTS OF APPENDIX A

Section

A1. FINITE-ELEMENT MODELS

A2. FINITE-ELEMENT ANALYSIS INPUTS AND OUTPUTS
Page

A. 4

$A-31$

A.3 


\section{A1. FINITE-ELEMENT MODELS}

The Shielded Receiver Lifting Frame Assembly (SRLF) (Drawing H-2-690044, Sh. 1 \& 2) is installed on the core sampler truck drill rig (Drawing H-2-690043) and supports the Shielded Receiver Assembly (Drawing H-2-90020). The Lifing Frame Assembly consists of two parts; the Moveable Frame Assembly shown on Drawing H-2-690044, Sh. 1 (Page A-6) to which the Receiver Assembly is attached, and the Stationary Fixed Support Frame Assembly as shown on Drawing H-2-690044, Sh. 2, (Page A-7) which provide alignment for the moveable frame. The moveable frame is raised and lowered by a pair of hydraulic cylinders. During transportation the moveable frame is in the down position and facing forward, while for operation it is in its full up position. Both frames are fabricated from standard structural steel shapes connected with welded joints.

The purpose of these analyses was to determine the forces in the welded joints and the stresses in the members of the SRLF. The analyses loads are: the receiver assembly deadweight, self weight of the frames, and potential transportation loads. To accomplish this, three dimensional finiteelement models were generated for both frames utilizing the MMAGES-3D computer program. One model depicted the moveable frame located in the operating (up) position while the second located it in the transportation (down) position. Beam elements were used for all of the frame members and truss elements for the hydraulic cylinders. Lateral loading between the frames was accomplished with stiff linear springs located at the roller locations which were in contact. Pages A-3 through A-24 show various plots of the geometry models.

The Receiver Assembly deadweight was applied as uniform loads to the moveable frame's horizontal forward and aft members $(\mathrm{P} / \mathrm{N} 3)$, at the attachment points. This is shown in on page A-25. In addition, the self weight of the frame was included by a $1 G$ gravity load. The potential dynamic loads generated during transportation were applied in three orthogonal directions and were combined with the deadweight of frames and receiver in lower position and for two longitudinal load cases. One case being the aft load and the second as forward load condition. The aft $(\mathrm{f} x=+0.43 \mathrm{G})$, forward $(\mathrm{f} x=-0.43 \mathrm{G})$, side $(f z=0.37 \mathrm{G})$ and vertical

(fy $=-.18 \mathrm{G}$ ) loads applied to the frame assembly to simulate the effect of dynamic loading as reported in Rollover Analysis of Rotary Mode Core Sampler Truck \#2 (WHC-SD-WM-ER-391, Rev.0). The boundary conditions imposed on the model included vertical restraint of the actuators and fixed joints between the drill rig and the Fixed Support Frame af bracing horizontal members (P/N 3). The $6 \times 4$ tube steel bottom member $(P / N 7)$ of the Fixed Support Frame was also restrained against translation and rotation about its torsional axis for one case and only against translation in the second case. These two boundary condition cases were analyzed to provide the worst case loads for these welded joints as well as other affected joints.

The input and output for each of the up/down deadweight and af/forward transport finite-element models for each of the two boundary conditions is given in Section A2. The resulting weld joint forces, the maximum stresses in frame members and their evaluation are given in Appendix $B$. 
RPP-6018, Rev. 0
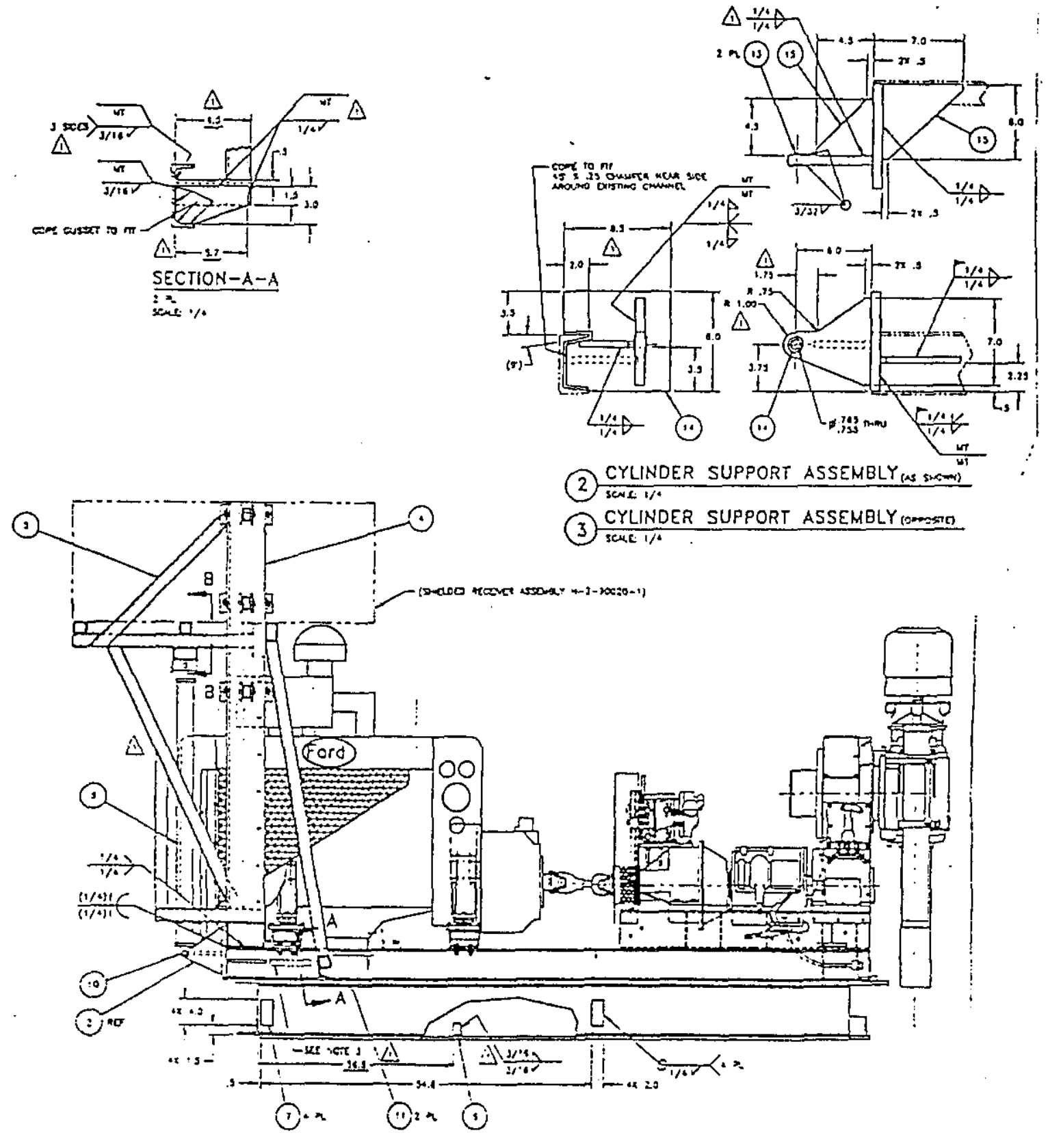

Dwe. $H-2-690043$

$A-5$ 
RPP-6018, Rev. 0

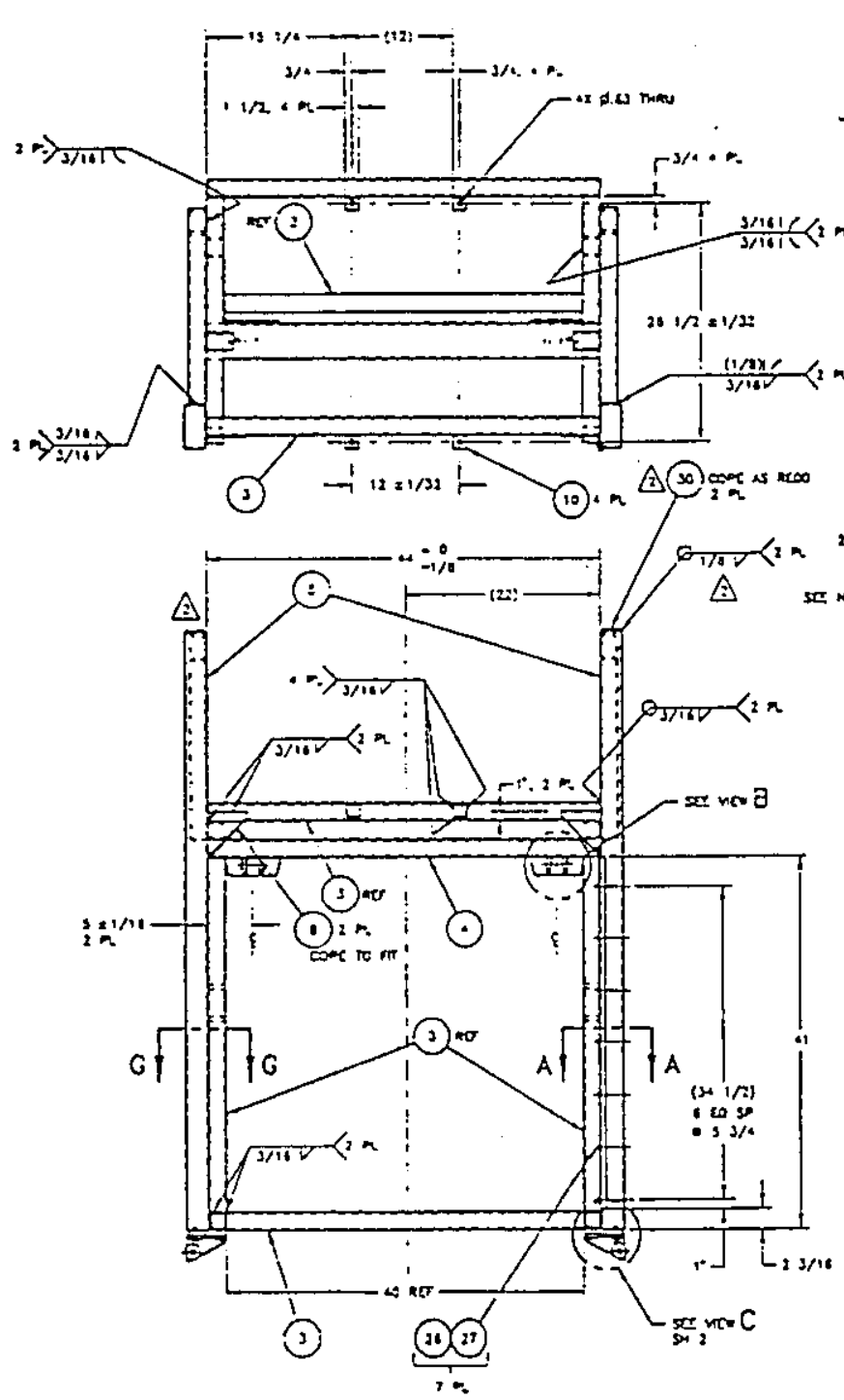

(1) SUPPORT FRAME ASSEMBLY
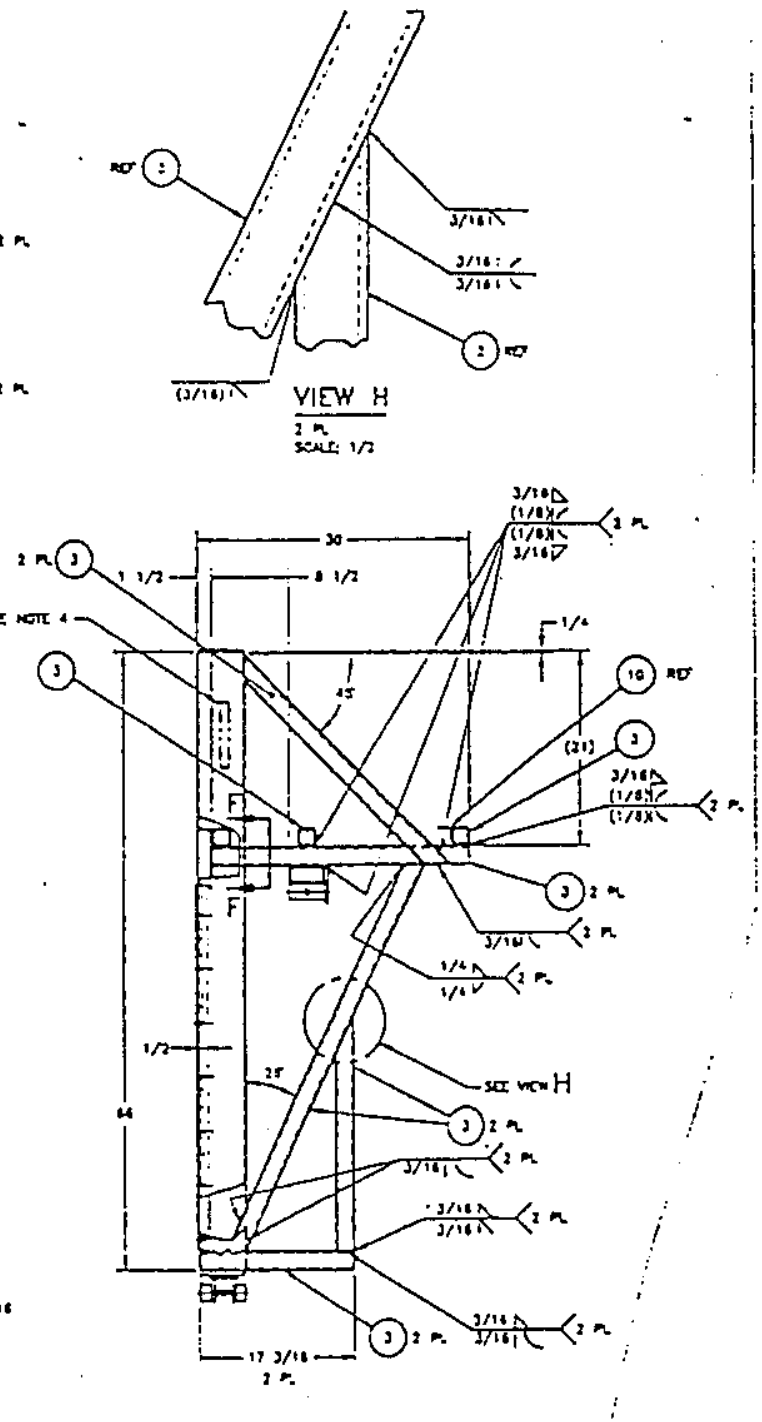

DWG $H-Z-6900445 H-1$

$$
\text { A- } 6
$$


RPP-6018, Rev. 0
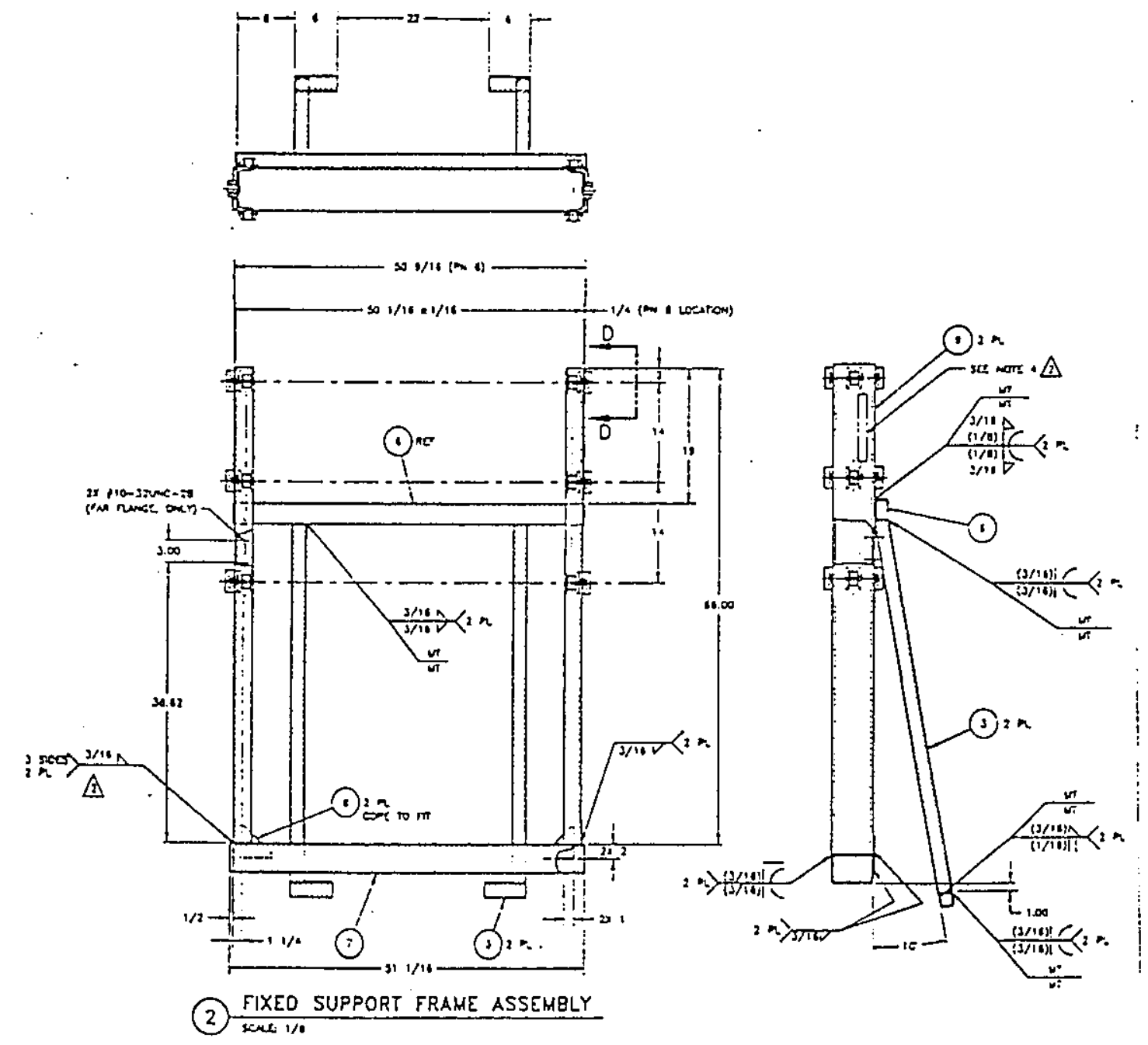

DWG. H-Z-690044 SH.Z

$$
\text { A-7 }
$$


RPP-6018, Rev. 0
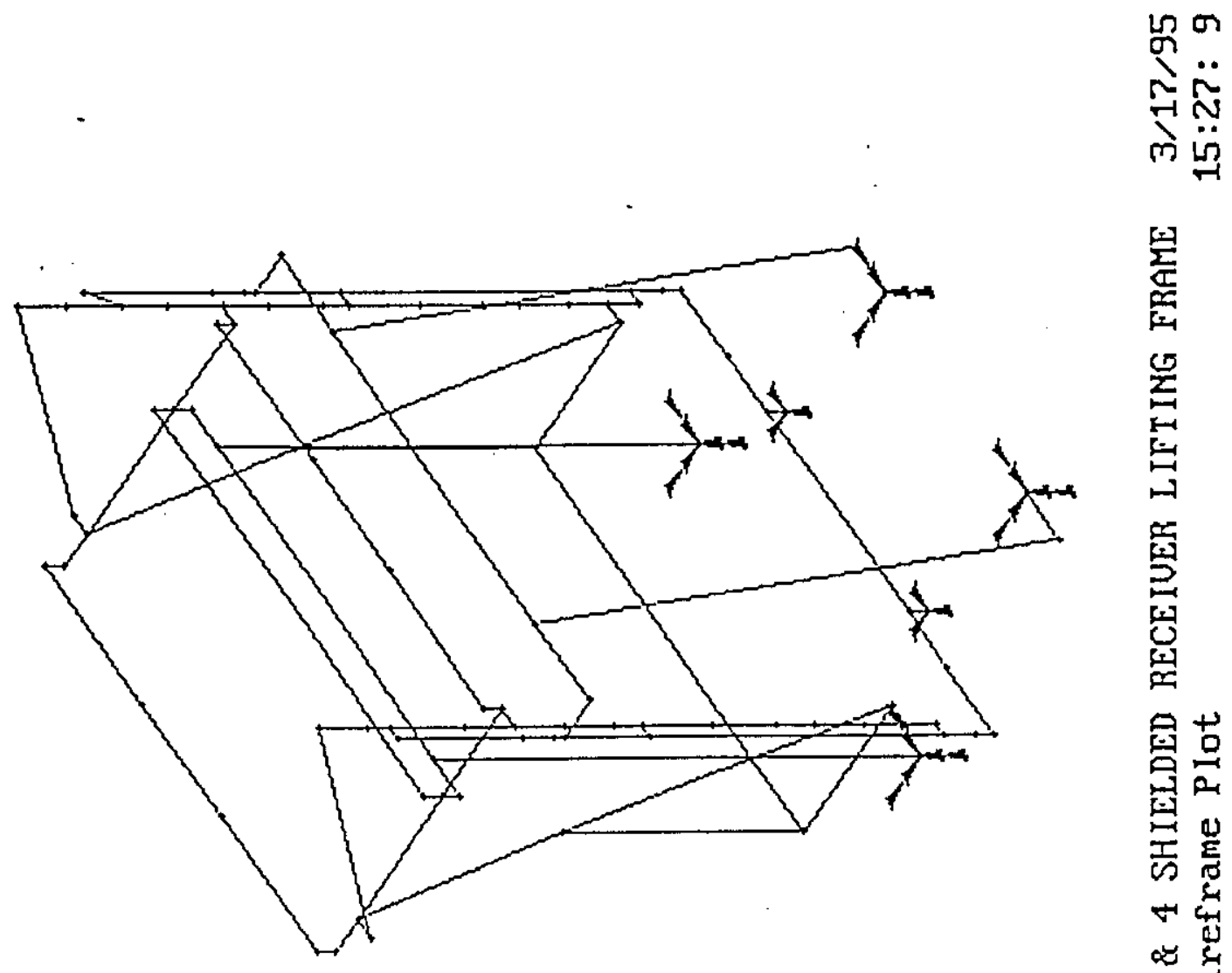

至

氙

实

مी

零

$\nabla c$

क s

m $\Xi$

${ }_{2}^{0}$

它

mo

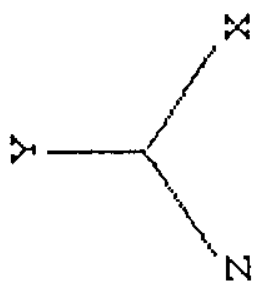

告

$A-B$ 
RPP-6018, Rev. 0

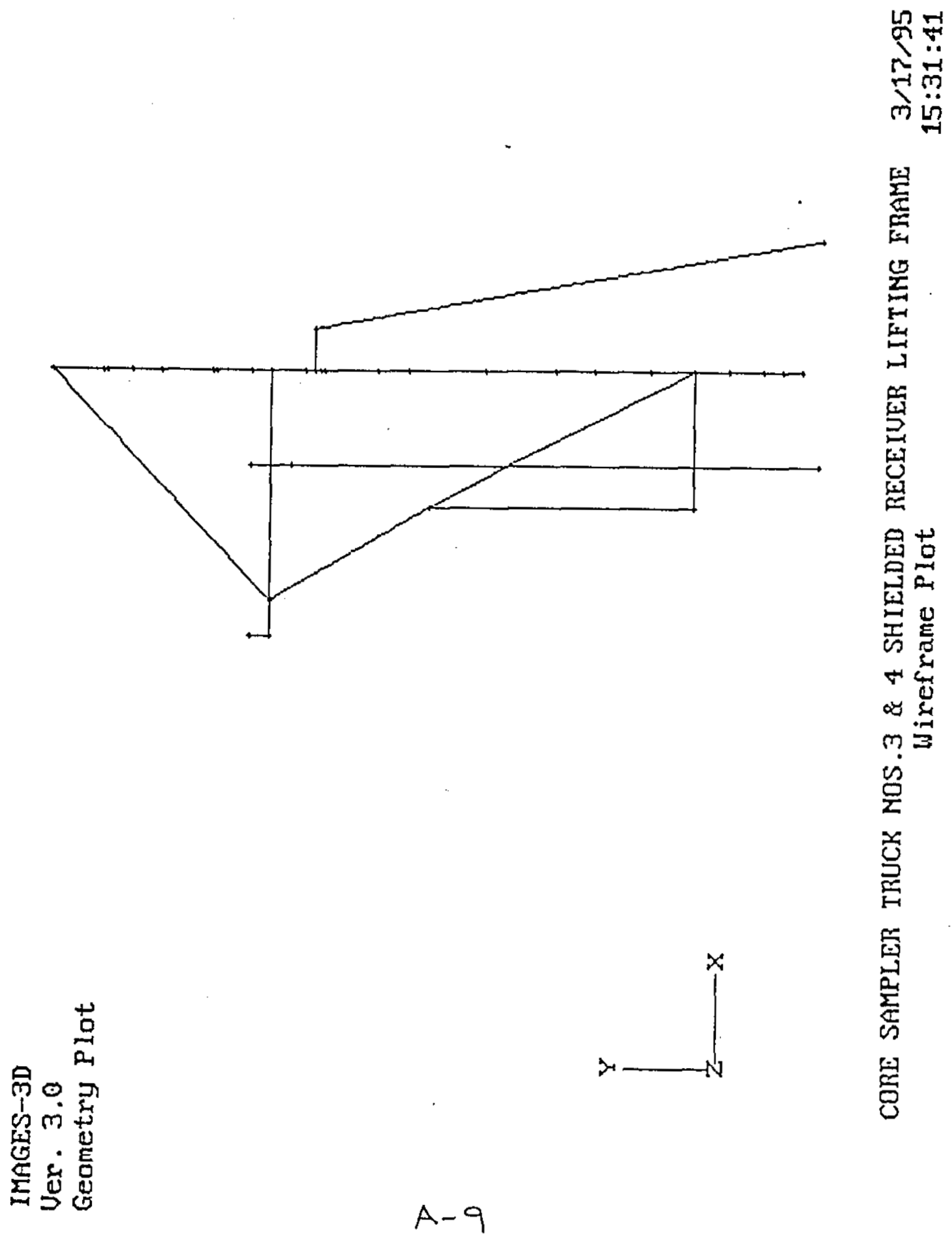

C-30 
RPP-6018, Rev. 0

吕

덕

ते पु

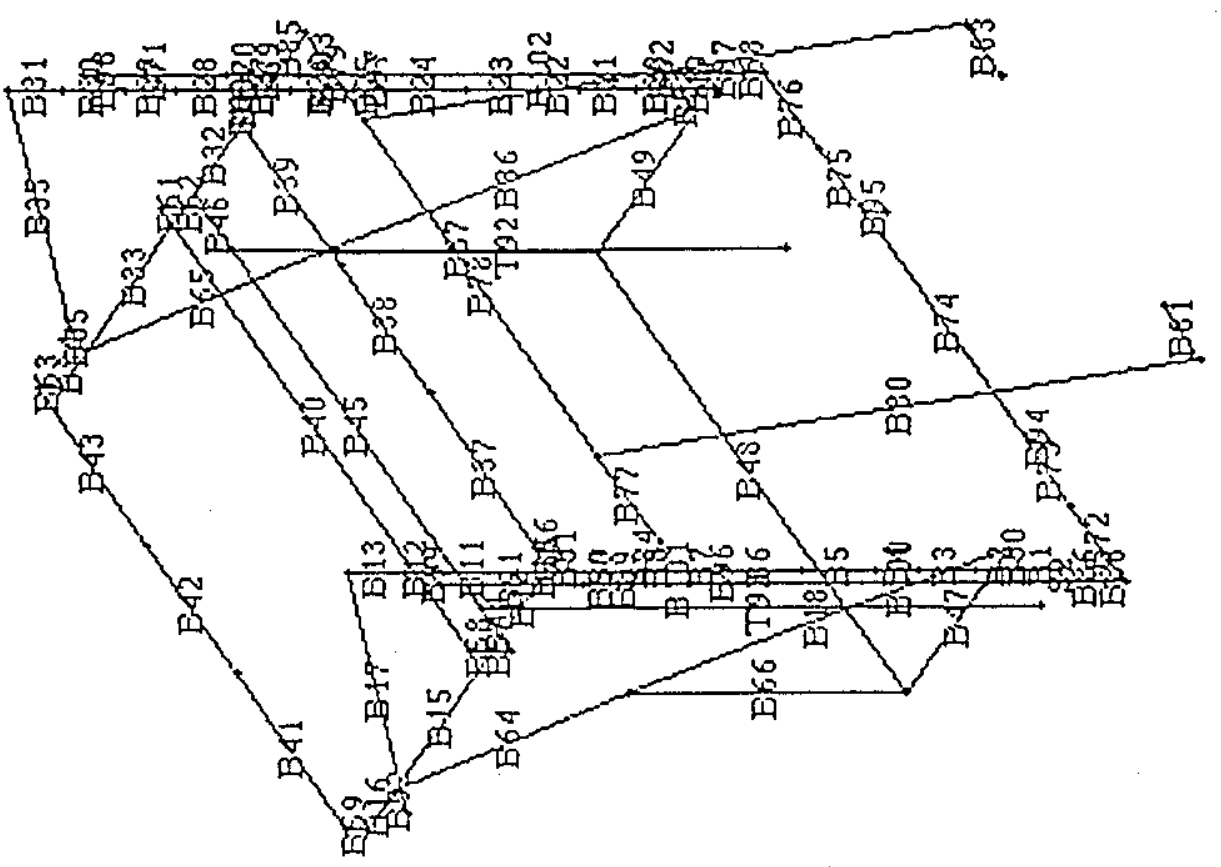

需

点

穿

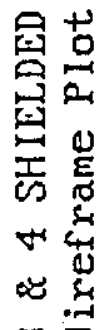

$m 3$

必

煎

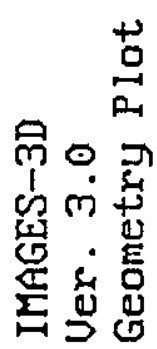

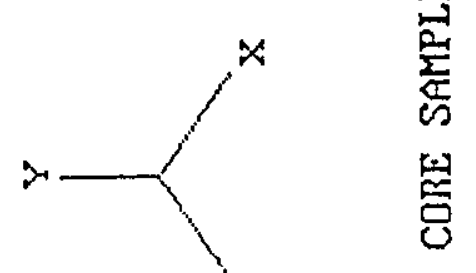

怘

$$
A-10
$$


RPP-6018, Rev. 0

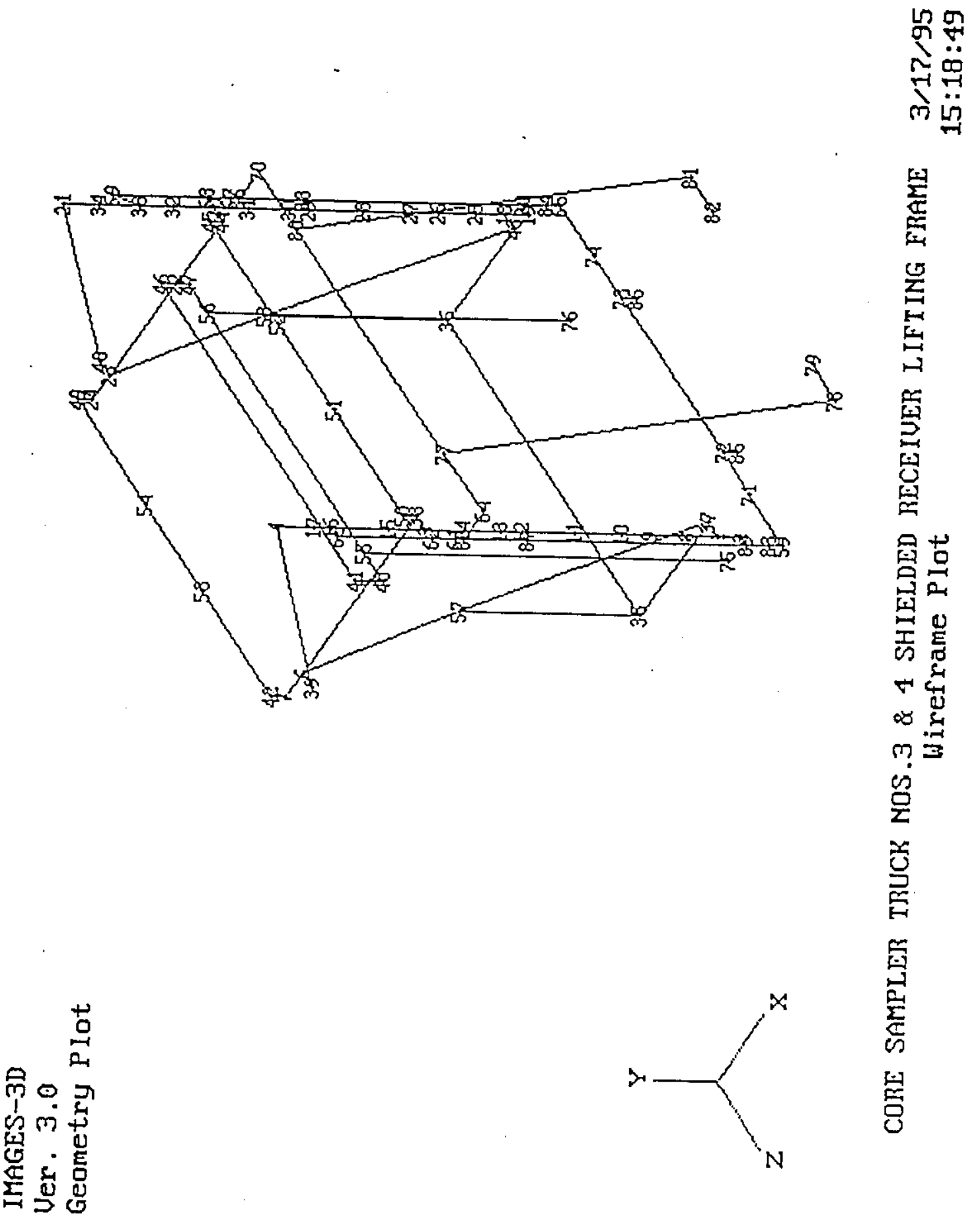

$A-11$ 
RPP-6018, Rev. 0

no

N..

กั ติ

त?

ला

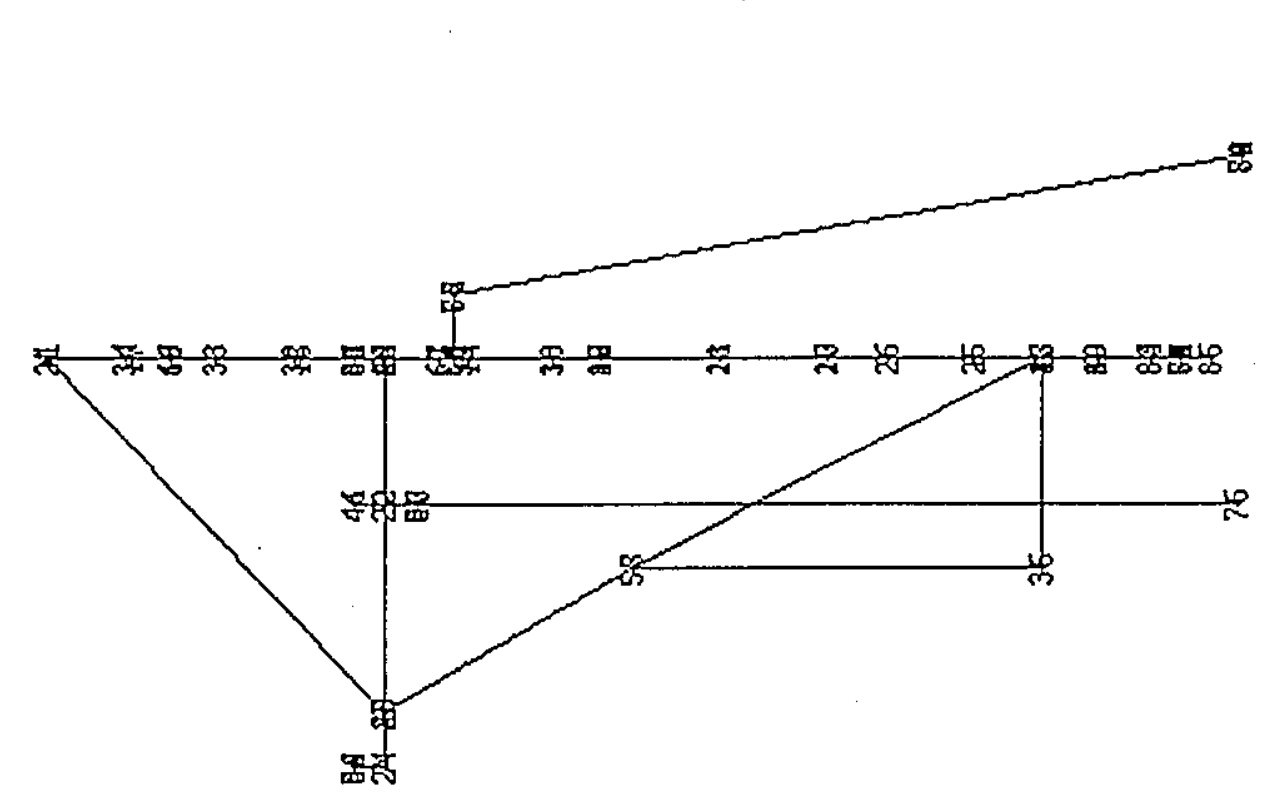

䆓

电

武

电

国茄

品

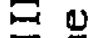

宁苋

$+4$

क

$m=$

总

ㄴ.

果

蛋

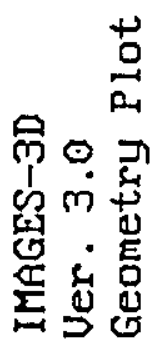

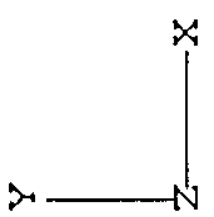

窇

$$
A-12
$$


RPP-6018, Rev. 0
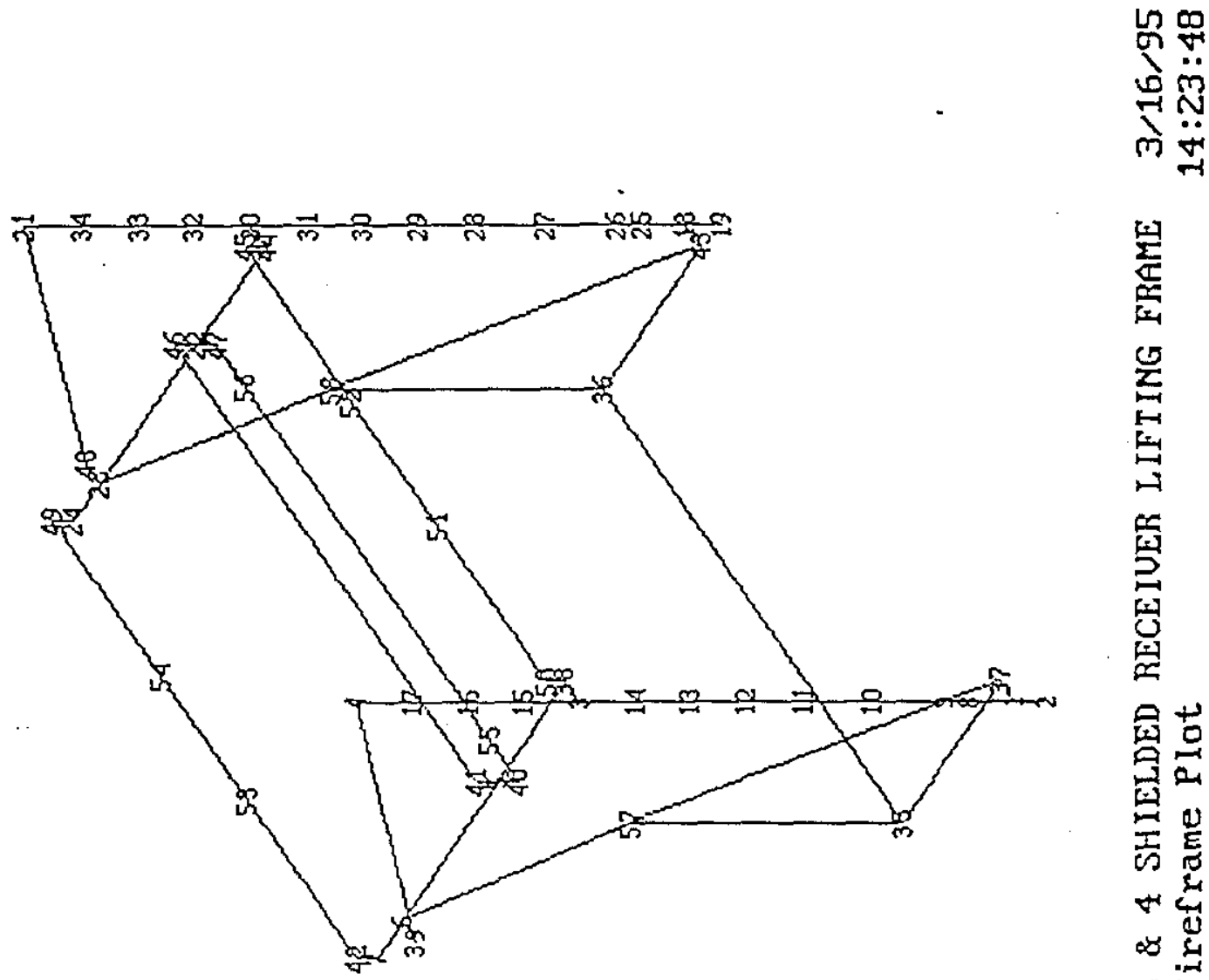

涳

点

穿

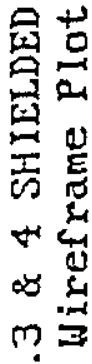

象

总

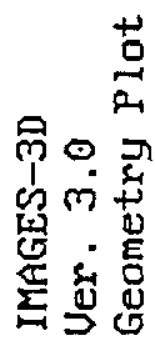

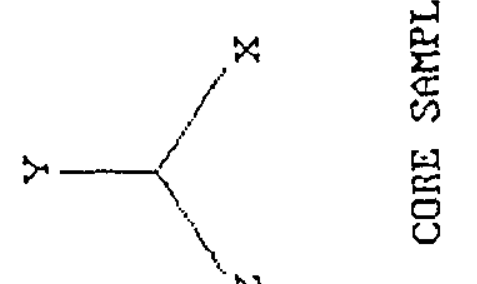

$$
A-13
$$


RPP-6018, Rev. 0

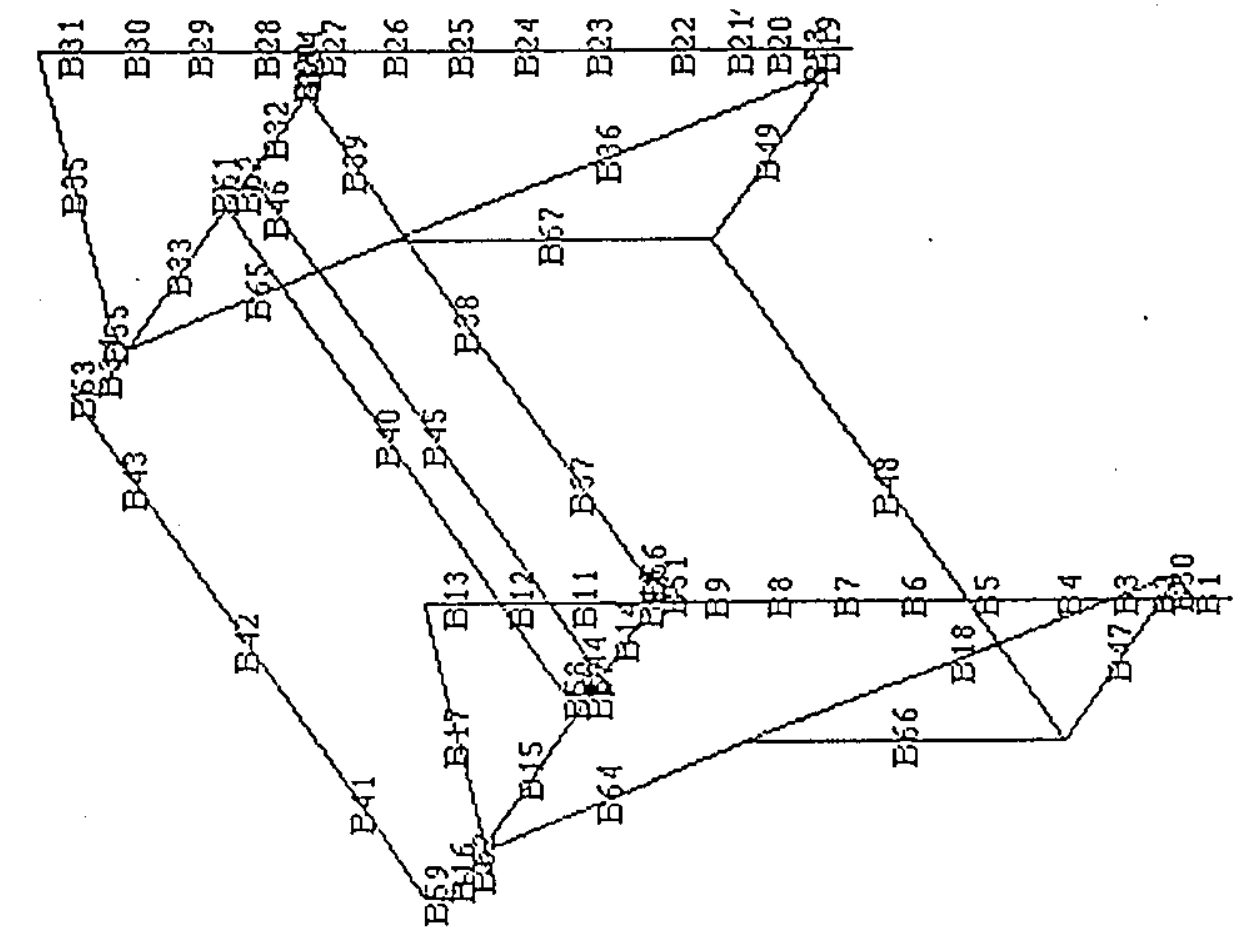

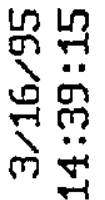

$\frac{5}{c}$

告

整

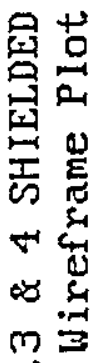

完

它

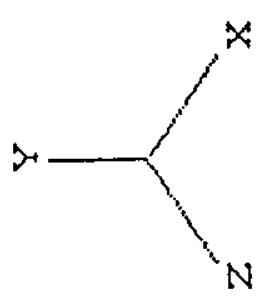

告

กิ

光

牙 :

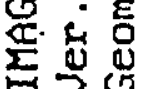

$A-14$ 
RPP-6018, Rev. 0

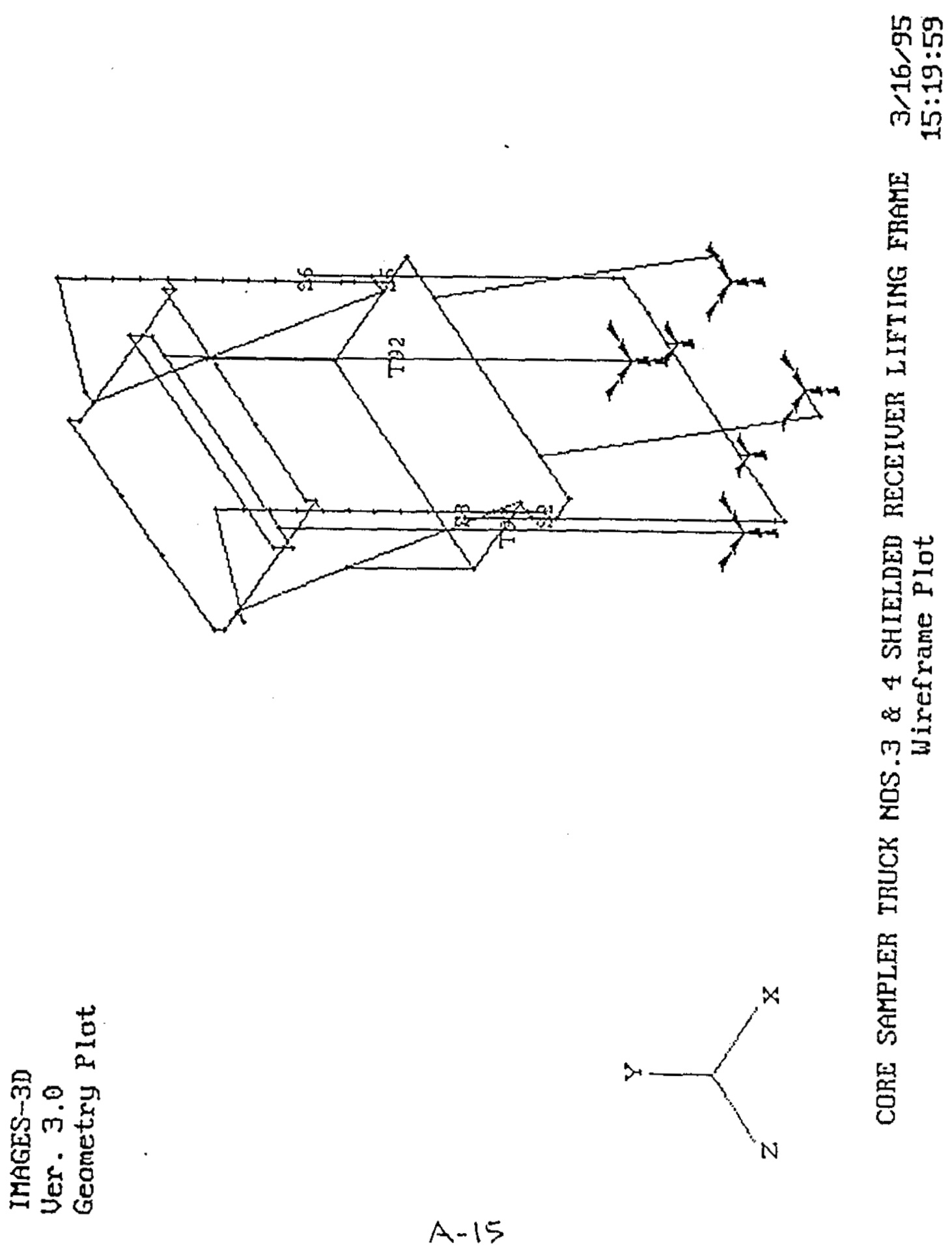


RPP-6018, Rev. 0

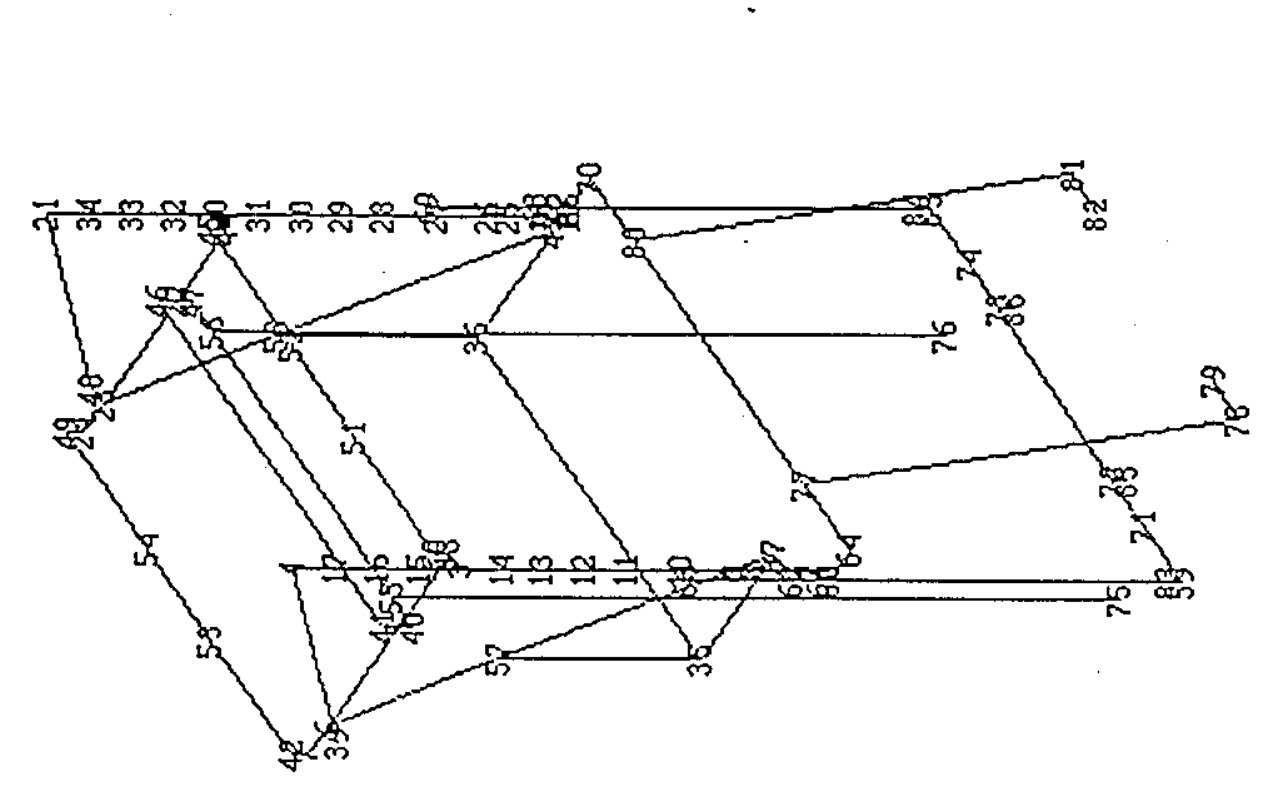

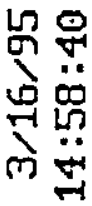

武

罢

密

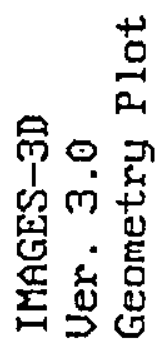

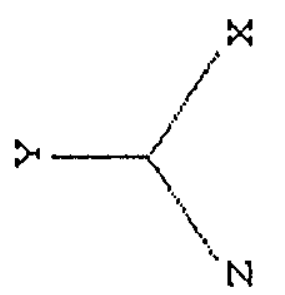

氛薄

的

ه

m

完

臿

舀

$$
\text { A. } 16
$$


RPP-6018, Rev. 0

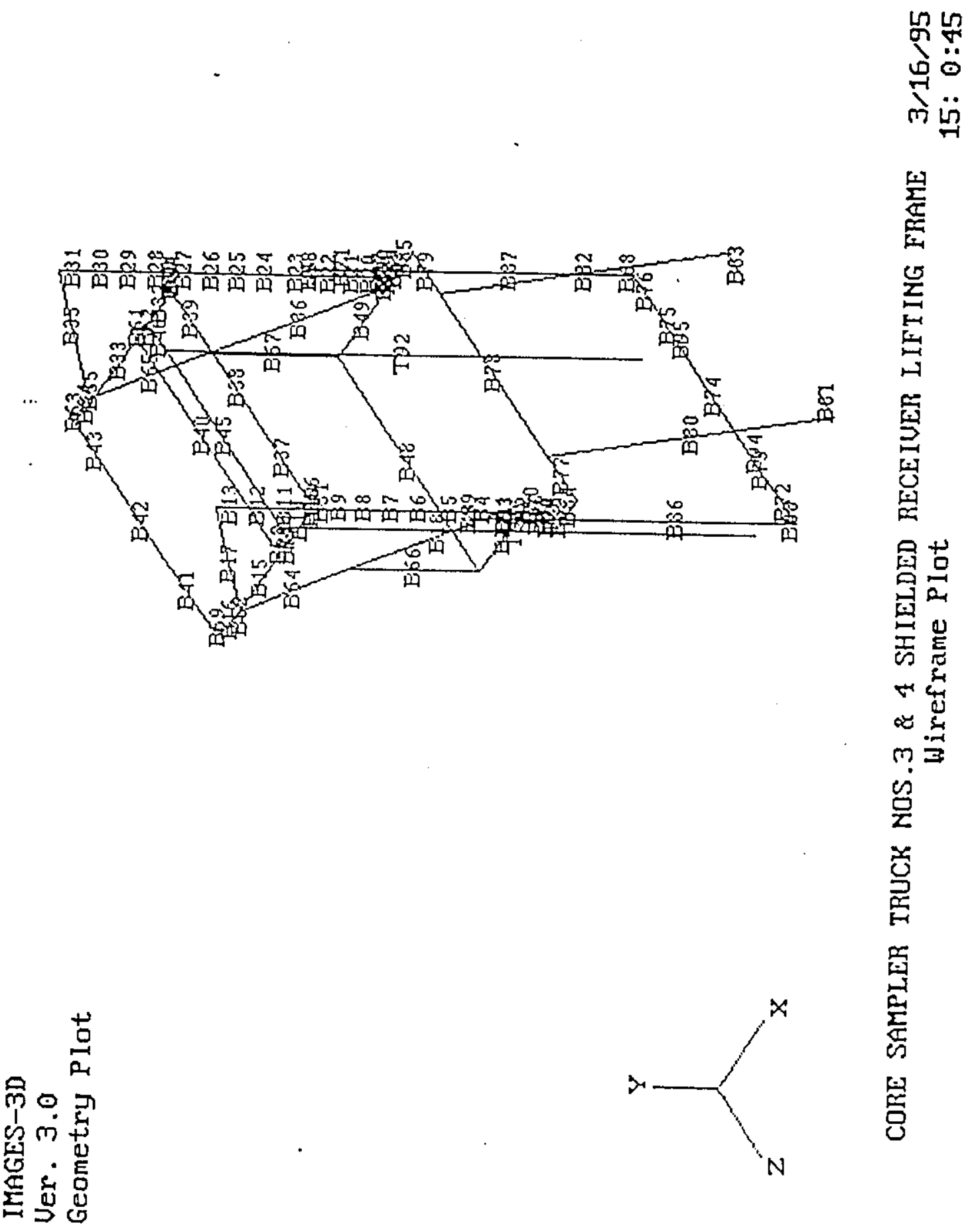

$A-17$ 
RPP-6018, Rev. 0

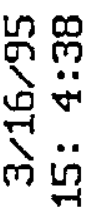

空

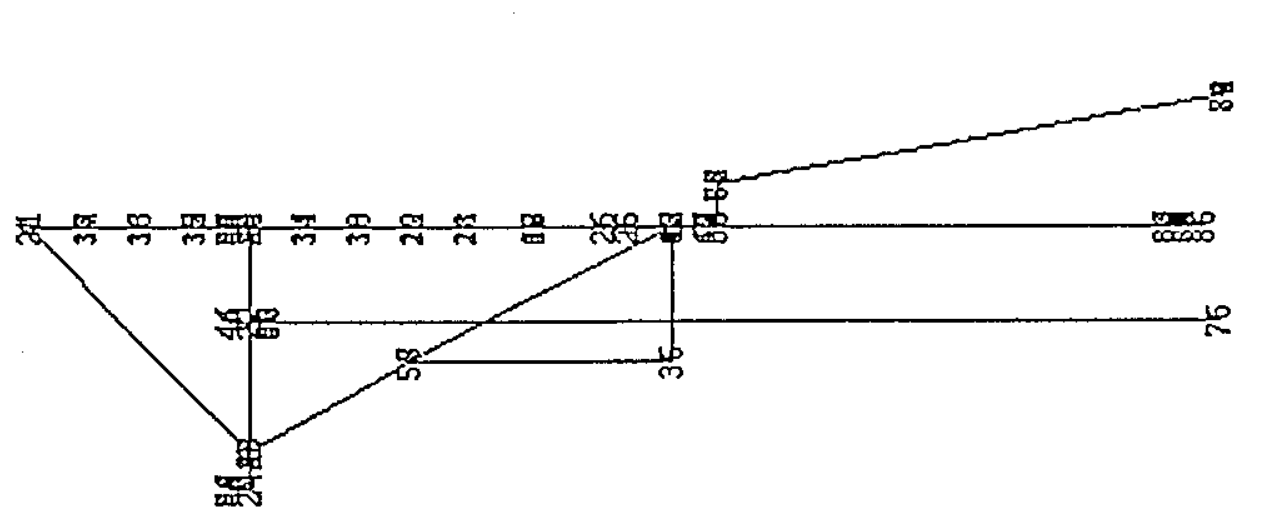

告

$\Leftrightarrow$

$\rightarrow$ a

님

도

$\nabla \stackrel{4}{4}$

$\infty$

$m=$

总

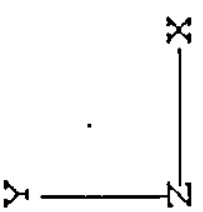

宊

ติ ․ㅠ

का क्ष

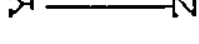

它

崩.

近电兄

핀

$$
A-18
$$


RPP-6018, Rev. 0

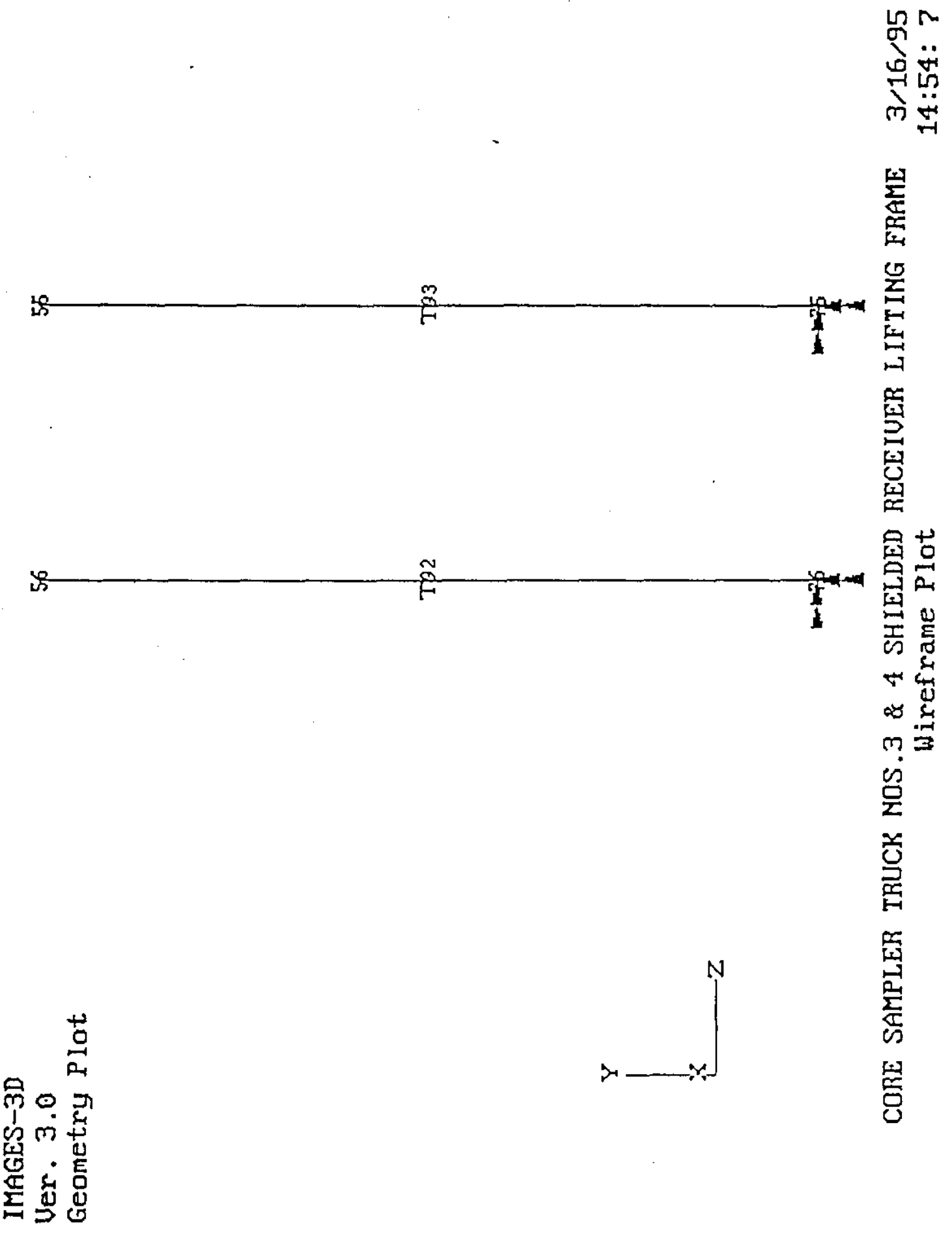

$A-20$ 
RPP-6018, Rev. 0

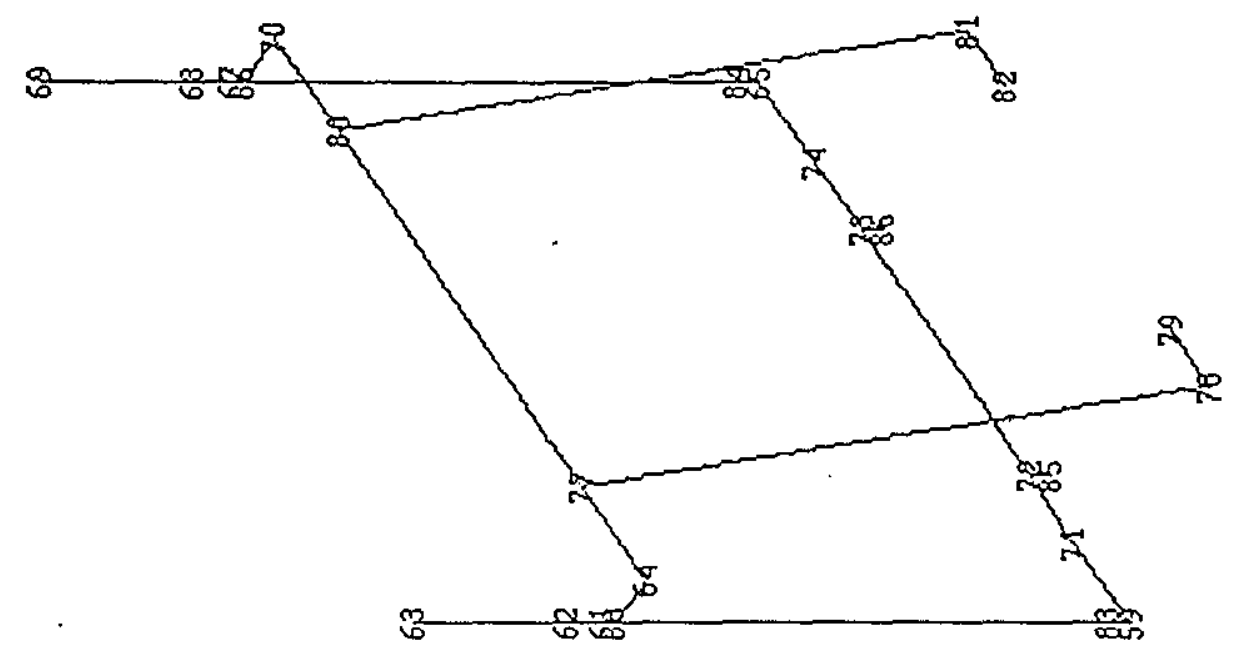

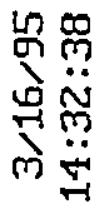

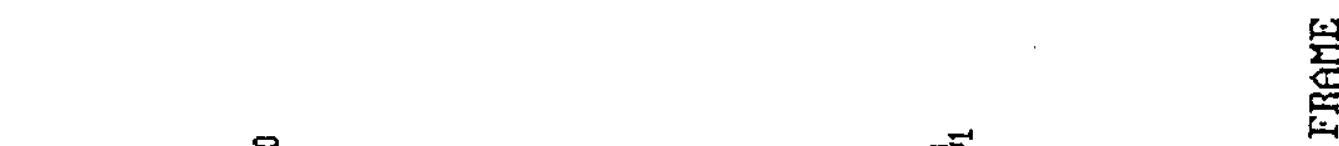

幽

2

量

愛

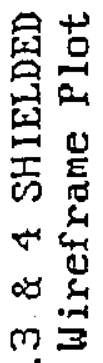

品

莺

告

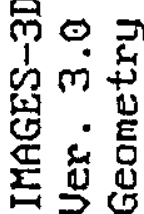

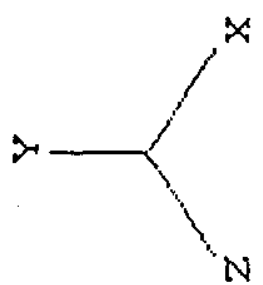

$$
A-21
$$


RPP-6018, Rev. 0
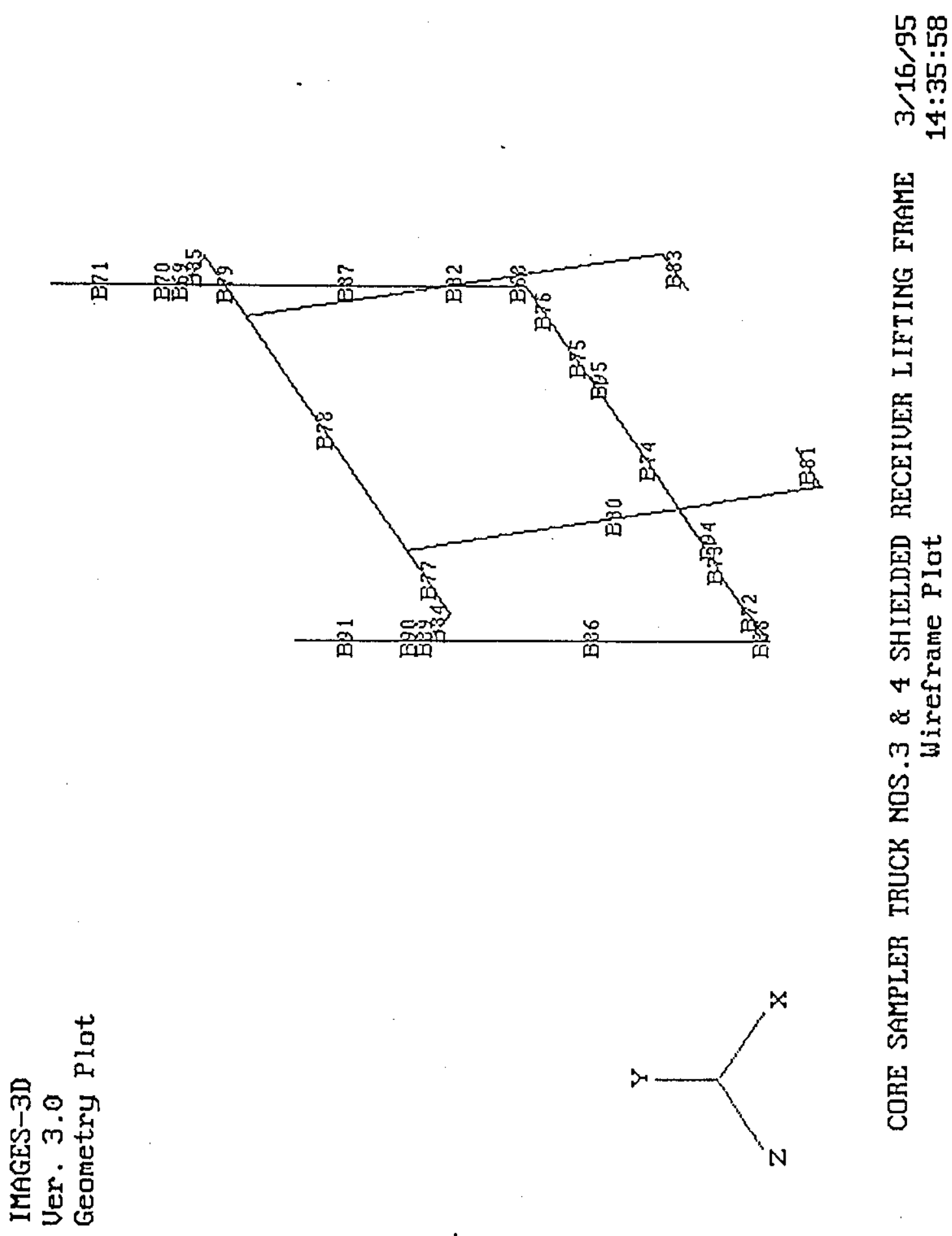

这

空

氠

国

回

国

永

षद

\&

$m 3$

完

它

嵒

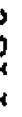

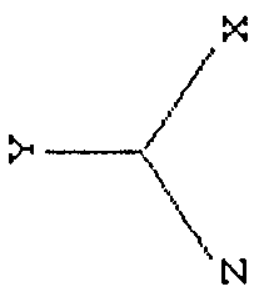

量

点

$A-22$ 
RPP-6018, Rev. 0

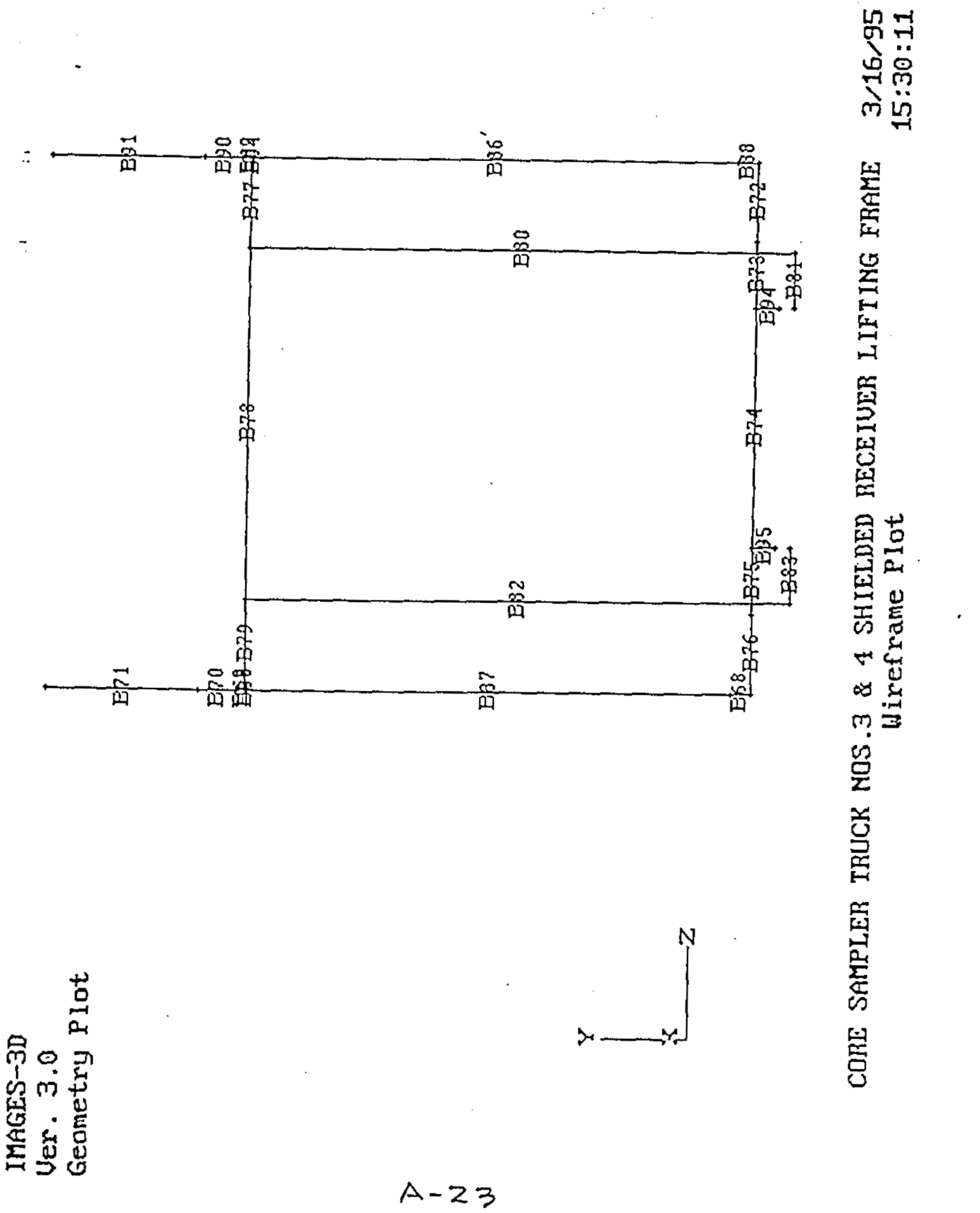


RPP-6018, Rev. 0

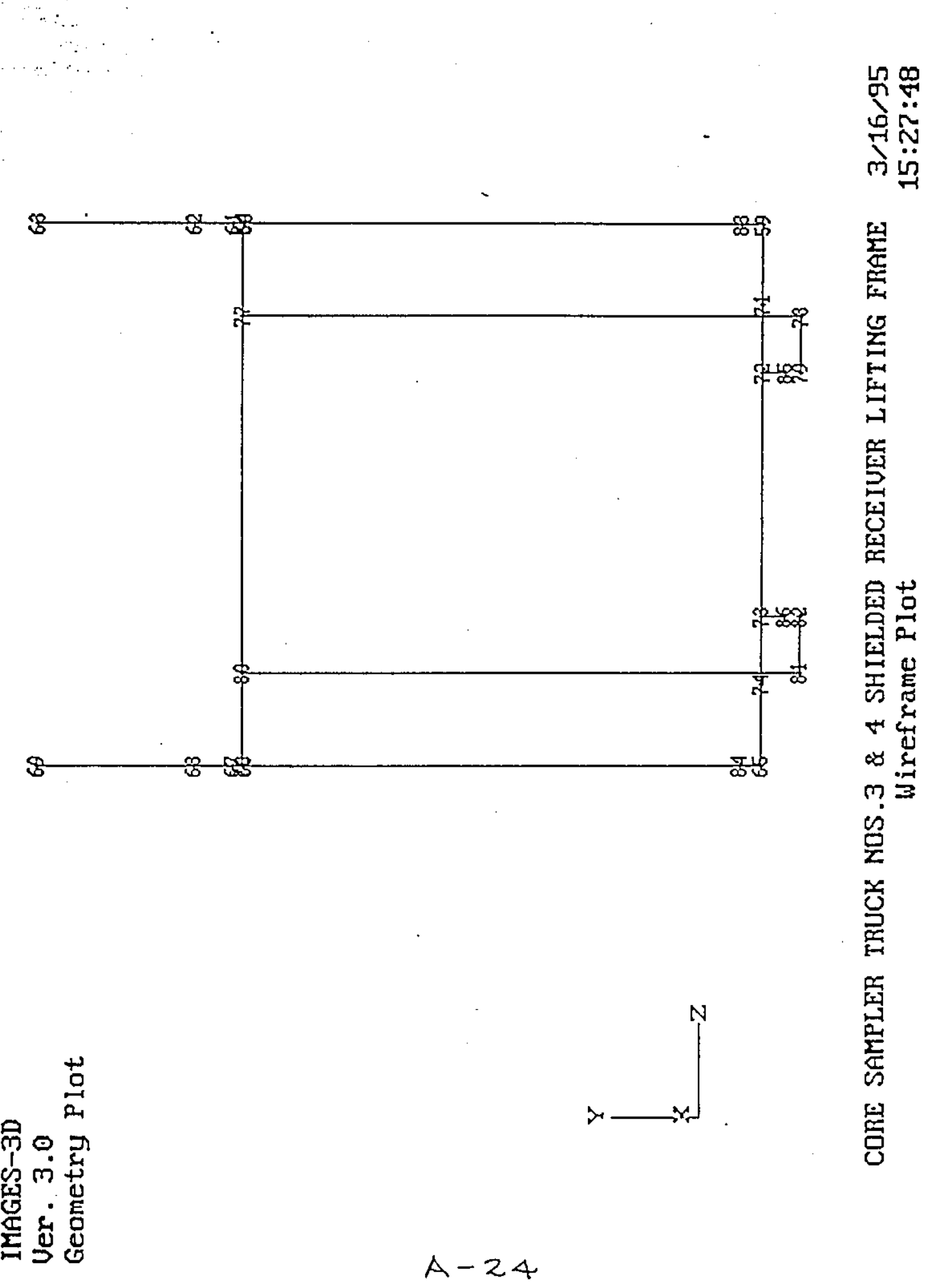




\section{DESIGN CALCULATION}

(1) Drawing $\mathrm{H}-2-690044$ (2) Doc. No.

(4) Building N/A_ (S) Rev.

(3) Page _ _ of 5

(7) Subject TRUCK \#3 \& SRLF ASSENBLEY

(8) Originator D d d d Date $3-14-95$

(9) Checker

FiR Vuafiet

Date $5 / 4 / 95$

(10)

APPLIED LOADS
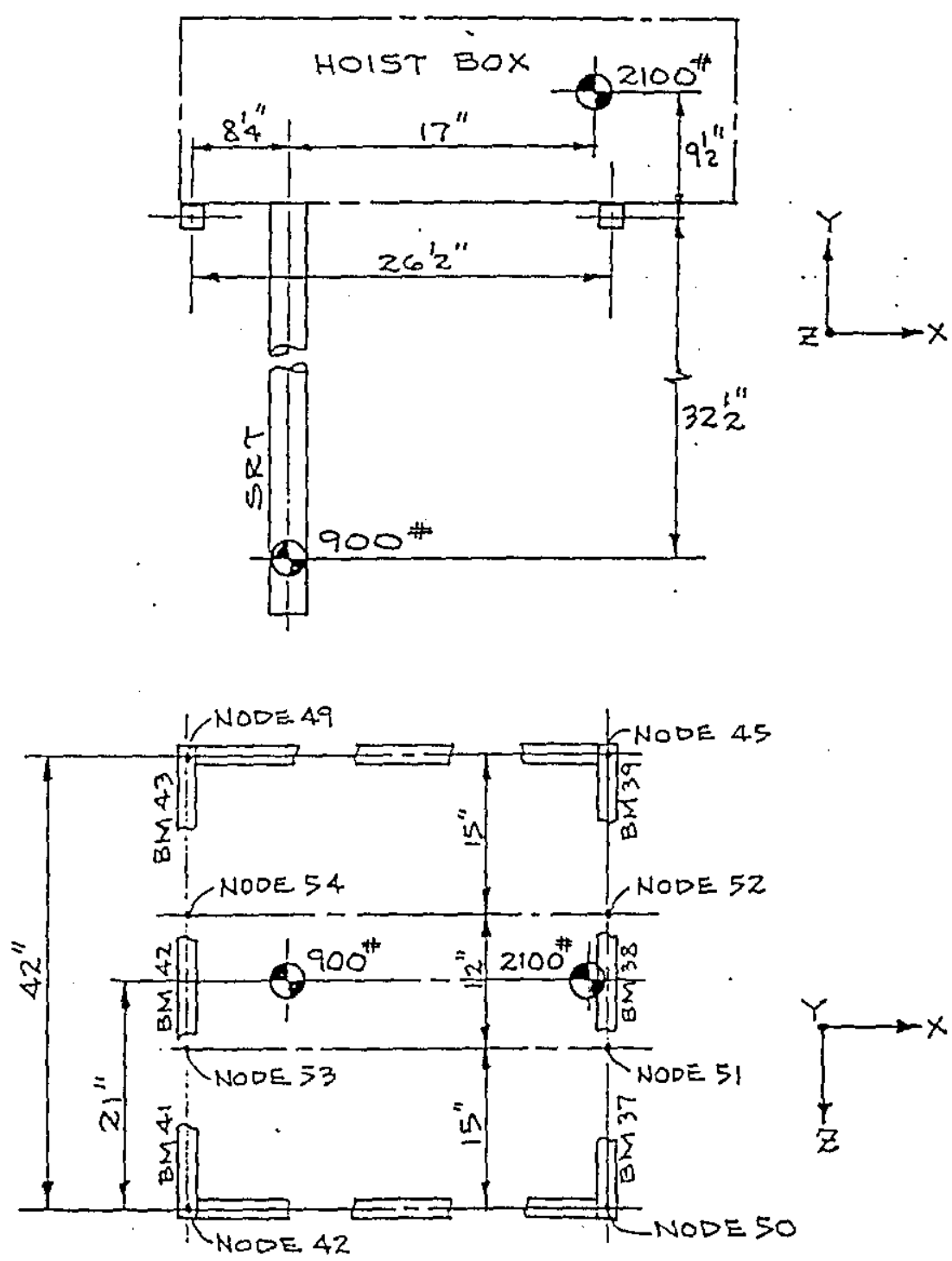

DEASWEIGHT LOADS: $(-16, Y$ AXIS $)$

BEAMS $37,38 \neq 39=(8.25 \times 900+25.25 \times 2100) /(26.5 \times 42)=54.31$ " $/$ in $\Rightarrow 76 \%$

BEAMS $41,42 \neq 43=(18.25 \times 900+1.25 \times 2100) /(26.5 \times 42)=17.12^{\# / \text { in }} \Rightarrow 24 \%$

$A-25$

$50.6400 .0601(12.87)$ 
RPP-6018, Rev. 0

DESIGN CALCULATION

(1) Orawing $\mathrm{H}-2-690044$

(2) Doc. No.

(3) Page $2^{-}$of

(4) Building

(5) Rev.

(6) Job No.

(7) Subject IRUCK \#3 \& SRLF ASSEMBLEY

(8) Originator

(9) Checker

E.R, Voukeri

Date $3-14-95$

Date

(10)

APPLIEO LOADS (AFT) i.e. $F_{x}=1 G E F_{z}=1 G$
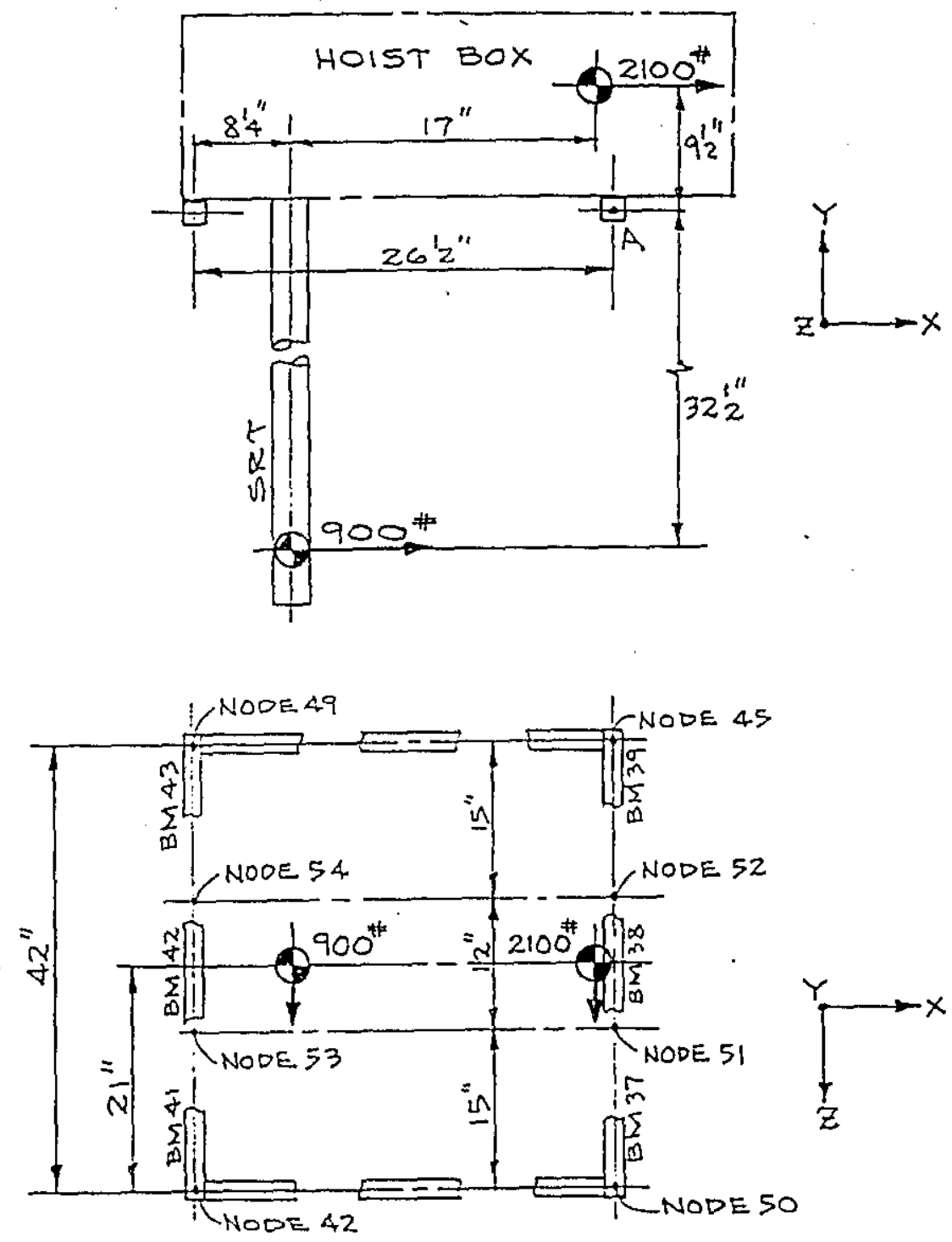

$A-26$

$80.66 \% 0 \cdot \div 001(1237$

C-46 


\section{DESIGN CALCULATION}

(1) Drawing $H-2-690044$ (2) Doc. No

(4) Building

(5) Rev.

(3) Page 3 of 5

(7) Subject TRUCK $\leq N 0.3$ \$ 4

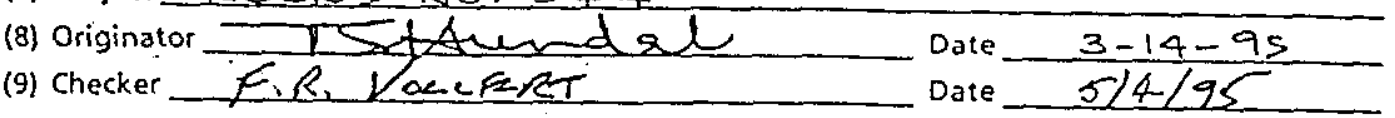

(10)

(10) $\cdots, \cdots, \quad, \quad a_{1}$

UOSOS

TRANSRORTATION LOAPSWWIFRANE IN DOWNOPOSITION

DETERMINE UOAOS ON OUTER BEAMS $(37,38439,41,42443)$

DUE TO (tFX) LOADS (TAKE MOMENTS (OPT:A;P.Z)

$(900 \times 32.5-2100 \times 9.5) \frac{1}{26.5}=351 \neq$

UPLIFT:Q NOOE 51 T2 $5251 / 2=176$

DOWN LOAD ON BEAMS 41,42 \&3 $=351 / 42=8.36$ \#/in

F LOAD:@FOWE ANCHOR PONTS (NODES 51;52;53 54 )

ASSUME SAME PROPORTIONS AS FOR 1G DOWN LOADS

i.e:76\%@ NODES 51 \&2 \& 24\%@NODES.53\%54

$\therefore F_{x} @ 51+5 z=3000 \times 76 / 2=1140$ \#

$53+54=3000 \times \cdot 24 / 2=360 \% \cdots$

DUE. TO $\left(+F_{Z}\right)$ LOADS

TAKE MOMENTS QPT. B $(900 \times 32.5-2100 \times 9.5) \frac{1}{18}=517^{\#}$ HPLIFT@51=517x.76=393 $53=517 \times .24=124^{*}$

DOWN WDL ON BEAMS 38,39 $\$ 42,43$

\begin{tabular}{|c|c|c|}
\hline BEAM & (NODE) TO & (NODE) \\
\hline 38 & $\begin{array}{l}\text { LOAD } \\
(51) \\
0\end{array}$ & $\begin{array}{l}\text { LOAD } \\
(52) \\
12 \times 1.1=13.2 \neq / \mathrm{in}\end{array}$ \\
\hline 39 & 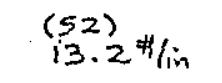 & $\begin{array}{l}(45) \\
29.11 \% \operatorname{lin}\end{array}$ \\
\hline 42 & $\begin{array}{c}(53) \\
0\end{array}$ & $12 \times \cdot 34=4.1^{4} / \mathrm{in}$ \\
\hline 43 & $\frac{(54)}{4.1} * \ln$ & $(4.5))$ \# 1 in \\
\hline
\end{tabular}

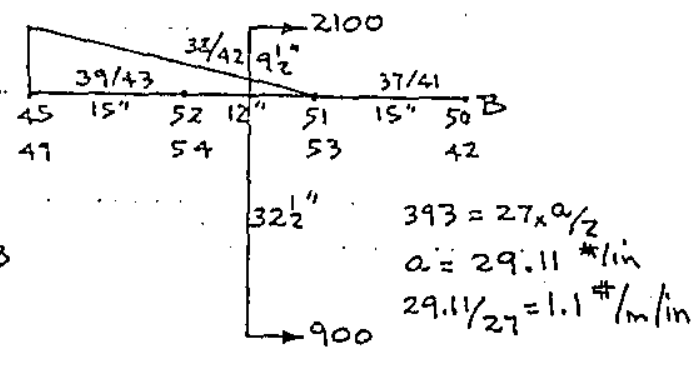

$12 a=27 \times b / 2$

$b=9.19 * / \mathrm{in}$

$9.19 / 2-3=34 \mathrm{t} / \mathrm{in} / \mathrm{in}$

SHEAR LOADS 24 ANCHOR POINTS (FZ)

$F_{Z} @$ NODE 51,52=1140\# \&@53\&54=360\#

$$
\Delta-27
$$

$B D .6400 .0601(12 / 87)$ 


\section{DESIGN CALCULATION}

(1) Drawing $\mathrm{H}-\mathrm{Z}-690044$

(4) Building

N/A

(2) Doc. NO.

(5) Rev.

(3) Page 4 of 5

(7) Subject $T R$ P $C K$ t $4 R$

(8) Originator

(9) Checker

EiRitanekT

Date

Date
$3-14-95$

$514 / 95$

(10)
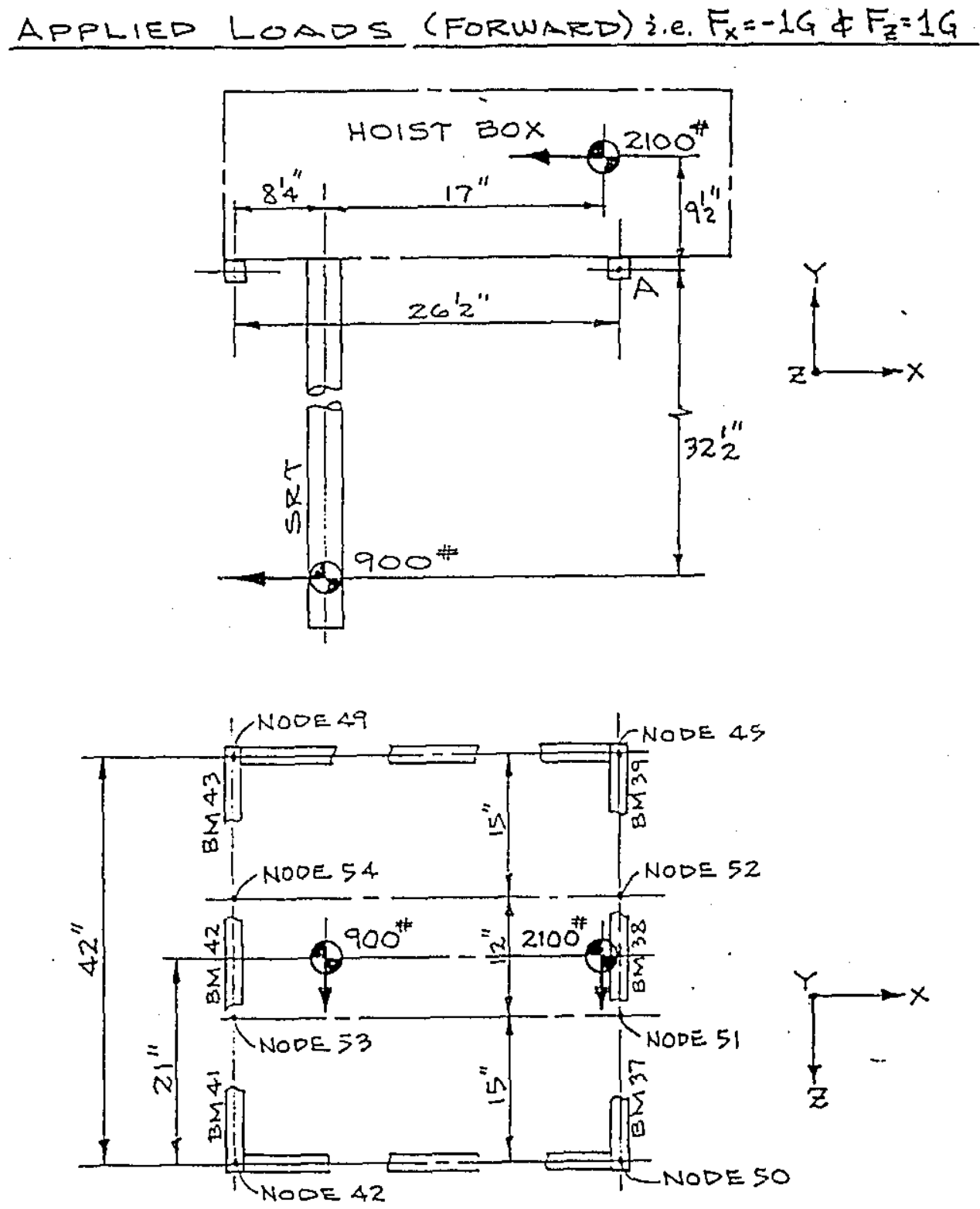

$A-28$ 


\section{DESIGN CALCULATION}

(1) Drawing: $\mathrm{H}=\mathrm{Z}-690044$ (2) DOC. No.

(4) Building

(5) Rev

(3) Page 5 of 5

(7) Subject TRUCKSNON3\&4

(8) Originator Date $3-14-95$

(9) checker F. $\ell_{\perp} V_{0 L L E R T}$

Date $5 / 4 / 95$

$(10)$

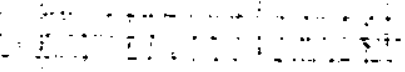

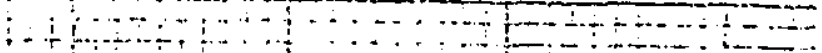

.

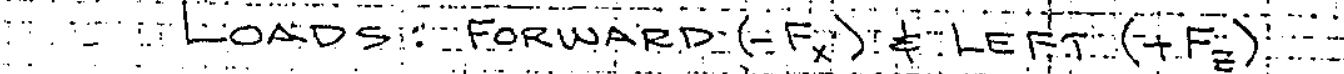

TRANSPORTATION LOAPS W/ERANE IN DOWUN POSITION

DETERMINE : LANOS ON OUTER BEANS $\left(37,38,39^{\circ} 44,42,43\right)$

DUE TO $\left(\div F_{x}\right)$ LOADS $\quad($ SEE $P(3)$

USINCE: FX.1S:REVERSED

$\therefore$ LPUIFT: Q NODE. 53 \& $54=176$

DOWN HOL ON BEAMS 37,38 \& $39=8.36$ 7lin

SHEMR' $\left(F_{X}\right)$ @ 4 ANCHOR-POINTS (NODES $51,52,53 \neq 54$ )

$F_{x} @ 51 ; 52 \cdots=-1140 \%$

$53,54=-360 \%$

DUE TO $\left(+F_{X}\right)$ LOADS

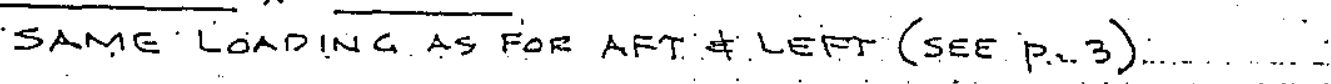

LPLIFT@ $11=393$ \#

$53=124^{4}$

DOWN HDL ON BEAMS $38,39,42 \notin 43$

\begin{tabular}{|c|c|c|c|}
\hline$B E A M$ & (NODE) & TO & (NODE) \\
\hline$\cdot$ & LOAD & & LORD \\
\hline 38 & $\begin{array}{c}(51) \\
0\end{array}$ & & $\begin{array}{l}(52\rangle \\
13.2\end{array}$ \\
\hline 39 & $\begin{array}{l}(52) \\
13.2\end{array}$ & & $\begin{array}{l}(45) \\
29.11 \neq \operatorname{lin}\end{array}$ \\
\hline $4 z^{\circ}$ & $\begin{array}{c}(53) \\
0\end{array}$ & & $\frac{(54)}{4.1}$ \#lin \\
\hline 43 & $\begin{array}{c}(54) \\
4.1\end{array}$ & & $\begin{array}{l}(4.9) \\
9.19 \neq 1 \mathrm{in}\end{array}$ \\
\hline
\end{tabular}

SHEARLOADS @ A ANCHOR POINTS

$F_{z} @ 51,52=1140 \#$

$53,54=360$ 深

$A-29$

$80.6400 .0601(12 / 87)$ 
RPP-6018, Rev. 0

APPENDIX B

STRESS ANALYSES, WELDED JOINTS, SHIELDED RECEIVER LIFTING FRAME, CORE SAMPLER TRUCKS \#3 AND $\# 4$

B-1 
RPP-6018, Rev. 0

ANALYTICAL CALCULATIONS

Page 1 of 62

Subject SRLE STRUSTURA ANALYCES, TRUCKS $3 \Rightarrow 4$

Originator FR.VOcceRT

Checker

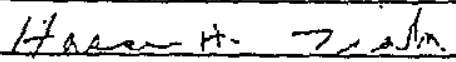

Date $5 / 3 / 95$

Date $6-30-35$

COMPUTER TUN ID NUMBERS

IMAGE: $3 D, V E R=I O N=.0$

DEAOWEIGHT ANALYSES

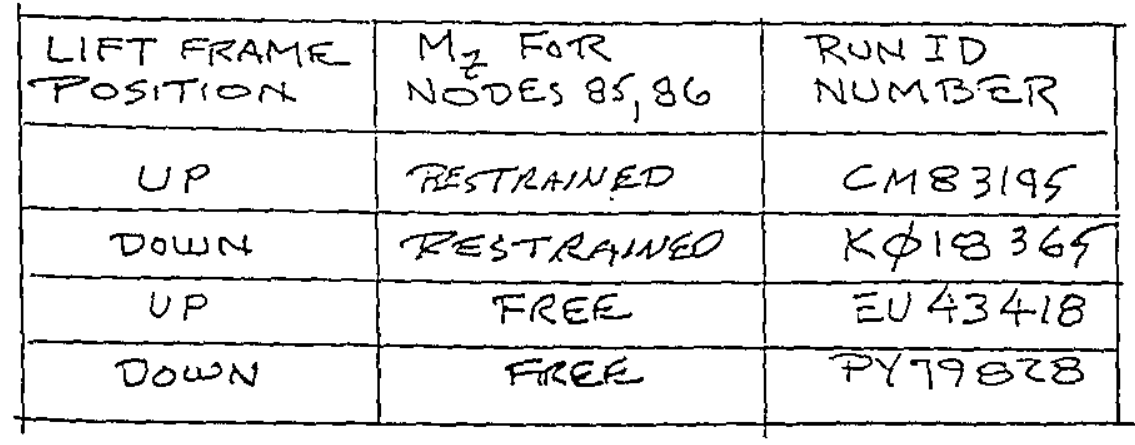

$\therefore$ TRANSPORTATION ANALYSES

$\therefore$\begin{tabular}{|c|c|c|}
\hline LONGITUDINAL & ME FOR & RUN ID \\
LOAD DIRETION & NODES 85,86 & NUMBER \\
\hline FORWARD & RESTRAiNED & IB 33923 \\
\hline AFT & RESTRAINED & YE 49602 \\
\hline FORWARD & FREE & GT 73150 \\
\hline AFT & FREE & HK 76347 \\
\hline
\end{tabular}

THE MEMBER FORCES AND STRESSEs, AND WELD JOINT FORCES FOR THE SRLF WERE COMPUTED BY THESE ANALYSES.

$B-2$

$80-8400-060.1(07 / 93)$

C-51 


\section{DESIGN CALCULATION}

(1) Drawing $\mathrm{H}=2-690044$ (2) Doc. No.

(4) Building__N N/A______ (5) Rev.

(3) Page 2 of 62

(7) SubjecL Core Sampler Truck Nos. 3 \& 4 Shielded Receiver Iifting Ename Assembly

(8) Originator F.R. i.cinERT

(9) Checker $\quad H a=H .2 a i / s$

Date $1 / 5 / 45$

Date $6-30-95$

\section{DEAD WEIGET ANALYSIS}

(Ref. Drawings $\mathrm{H}-2-690043$ and 690044 Sh. 1 \& 2)

WELD JONT FORCES: GLOBAL COOROINATES

MEMBERS $($ AND (3) TO F) Frame LIFTING

JOINT SKETCH:
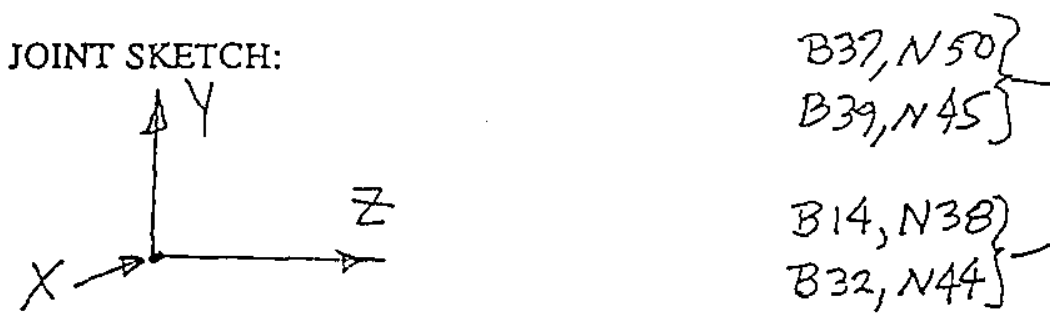

With $\mathrm{Mz}$ Restrained at Nodes 85 and 86

\begin{tabular}{|c|c|c|c|c|c|c|c|}
\hline $\begin{array}{l}\text { Moveable } \\
\text { Frame } \\
\text { Position }\end{array}$ & $\begin{array}{l}\text { Beam and } \\
\text { Node } \\
\text { Numbers }\end{array}$ & $\begin{array}{l}\text { Fx } \\
\text { lbs }\end{array}$ & lbs. & Ibs & $\begin{array}{l}\text { Mx } \\
\text { in-lbs }\end{array}$ & in-lbs & in-lbs \\
\hline \multirow{4}{*}{ UP } & $037, N 5^{\circ}$ & 0 & 1150 & 203 & 7065 & 223 & 7 \\
\hline & $A 39, N 4 S$ & 0 & 1150 & 203 & 7003 & 225 & 1 \\
\hline & $0 / 4, N 38$ & 211 & 1021 & 112 & 1680 & 146 & 5506 \\
\hline & 1332,144 & 211 & 1092 & 112 & 1688 & 146 & 5807 \\
\hline \multirow{4}{*}{$\begin{array}{c}\text { DOWN } \\
\ldots\end{array}$} & $337, \wedge 50$ & 0 & 1150 & 252 & 2136 & 746 & $\alpha$ \\
\hline & $339, N 45$ & 0 & 1150 & 252 & $7 / 34$ & 142 & 1 \\
\hline & 314,138 & 19 & 1119 & 756 & 1592 & 225 & 5872 \\
\hline & 1832,144 & 18 & 1119 & 156 & 1597 & 524 & 5872 \\
\hline
\end{tabular}

Without Mz Restrained at Nodes 85 and 86

\begin{tabular}{|c|c|c|c|c|c|c|c|}
\hline $\begin{array}{l}\text { Moveable } \\
\text { Frame } \\
\text { Position }\end{array}$ & $\begin{array}{l}\text { Beam and } \\
\text { Node } \\
\text { Numbers }\end{array}$ & Ibs & lbs & lbs & $\begin{array}{l}M x \\
\text { in-lbs }\end{array}$ & in-los & in-lbs \\
\hline \multirow{4}{*}{ UP } & $332, N 50$ & 0 & 1150 & 198 & 7055 & 232 & 1 \\
\hline & 839,445 & 0 & 1150 & 113 & 7052 & 233 & 1 \\
\hline & $314 \times 38$ & $2 / 2$ & 1091 & 108 & 1703 & 110 & 5504 \\
\hline & $B \geq 2, \Delta<44$ & $2 / 2$ & 1092 & 109 & 1703 & 110 & 5505 \\
\hline \multirow{4}{*}{ DOWN } & $832, N 50$ & 0 & 1150 & 255 & 2141 & $\angle 42$ & 1 \\
\hline & 335,145 & 0 & 1150 & 255 & 2139 & 143 & 1 \\
\hline & $8 \times 1,136$ & 19 & 1119 & 158 & 1590 & 323 & 5873 \\
\hline & & 19 & 1119 & 158 & 1589 & 592 & 5872 \\
\hline
\end{tabular}

$$
B-3
$$




\section{DESIGN CALCULATION}
(1) Drawing $\mathrm{H}-2-620044$
(2) Doc. No.
(3) Page 3 of: 62
(4) Building
N $\angle A$
(5) Rev.
(6) Job No.
(7) Subject Core Sampler Truck Nos 3 \& 4 Shielded Receiver Lifting Erame Assembly
(8) Originator $E, R, V 0 \leq x=$ Date $4 / 5 / 45$
(9) Checker Hawist- Zush
Date $6-30-35$

\section{TRANSPORTILADSANATXSIS}

(Ref. Drawings H-2-690043 and 690044 Sh. 1 \& 2)

WELD JOINT FORCES: . (Moveable Frame in Down Position)

MEMBBERS (3) AND (3) TOTE

JOINT SKETCH: GLOBAC COORDNATES<smiles>[Y]C(C)=[W]</smiles>

Frame LIFTING

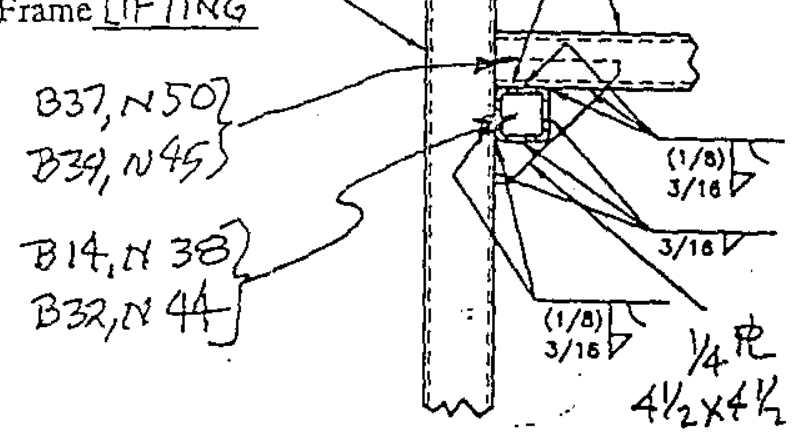

With Mz Restrained at Nodes 85 and 86

\begin{tabular}{|c|c|c|c|c|c|c|c|}
\hline $\begin{array}{l}\text { Longitudinal } \\
\text { Load } \\
\text { Direction }\end{array}$ & $\begin{array}{l}\text { Beam and } \\
\text { Node } \\
\text { Numbers }\end{array}$ & lbs & Ibs & lbs & in-lbs & in-lbs & in-Ibs \\
\hline \multirow{3}{*}{ FORWARD } & $032, N 50$ & 485 & 7516 & 1728 & 12050 & 3950 & 223 \\
\hline & $839 \sim 45$ & 503 & 1250 & 878 & 5434 & 4322 & 223 \\
\hline & $34, N 3 E$ & 10 & 1556 & 570 & $\frac{-15}{790}$ & 4557 & $\frac{8027}{6341}$ \\
\hline \multirow{4}{*}{$\begin{array}{l}\mathrm{AFT} \\
\therefore \therefore\end{array}$} & 037 N5O & 504 & 1443 & 401 & $\frac{12750}{1270}$ & 4334 & \\
\hline & $B_{3}+N 53$ & 485 & 1121 & 360 & 3349 & 3437 & 183 \\
\hline & & $2 \beta 1$ & 1562 & $4<6$ & 952 & $3+30$ & 7562 \\
\hline & B3 3,444 & 34 & 1021 & 284 & 2976 & 3005 & 5456 \\
\hline
\end{tabular}

Without Mz Restrained at Nodes 85 and 86

\begin{tabular}{|c|c|c|c|c|c|c|c|}
\hline $\begin{array}{l}\text { Longitudinal } \\
\text { Load } \\
\text { Direction }\end{array}$ & $\begin{array}{l}\text { Beam and } \\
\text { Node } \\
\text { Numbers }\end{array}$ & Ibs & Ibs & $\begin{array}{l}\text { Fz. } \\
\text { lbs }\end{array}$ & in $-1 b s$ & in-lbs & in-lbs \\
\hline \multirow{4}{*}{ FORWARD } & $3 n_{1} \wedge 0$ & 489 & 1537 & 2057 & 12280 & 4062 & 249 \\
\hline & 334.145 & 500 & 1330 & 1207 & 5305 & 4300 & 249 \\
\hline & $(B / 4,1,38$ & $3 I$ & 1320 & 574 & 204 & 4361 & 8067 \\
\hline & $\sqrt{33} 32 \sim 44$ & 308 & 1101 & 798 & 3336 & 5304 & 6367 \\
\hline \multirow{4}{*}{$\mathrm{AFT}$} & $830, N 50$ & 302 & 144 & 491 & 12710 & 429 & 209 \\
\hline & $839, \times 145$ & 486 & $1 / 23$ & 360 & 3395 & 3921 & 209 \\
\hline & $31 \times, r 138$ & 289 & 1566 & 466 & 960 & 3240 & 2564 \\
\hline & $8322, N 44$ & 40 & 1017 & 285 & 2979 & 3000 & 5461 \\
\hline
\end{tabular}

$$
B-4
$$




\section{ANALYTICAL CALCULATIONS}

Page 4 of 62

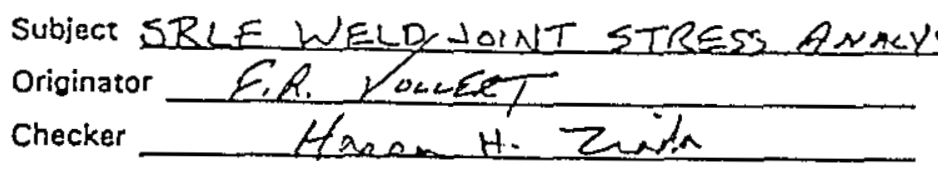

MEMABERS (2) AND (3) TO (5)

JOINT SKETCH:

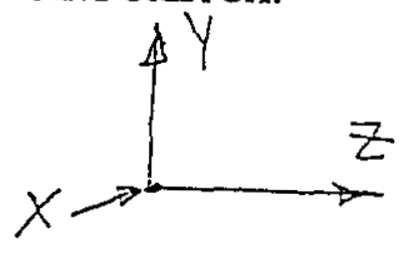

Frame LIFTiNG

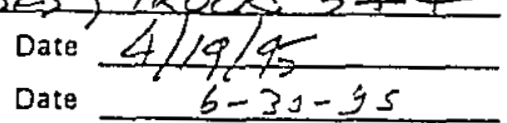

$\left.\begin{array}{cc}314 / 832 & B 14, N 38 \\ 1 & B 32, N 44\end{array}\right]$

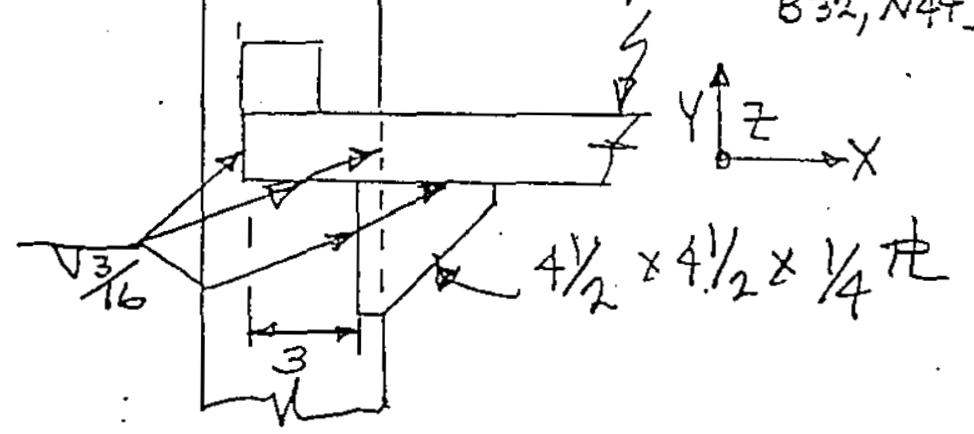

$337, N 50$
$B 39, N 45$

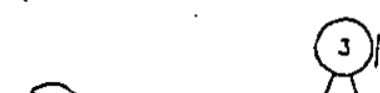

3

(5)

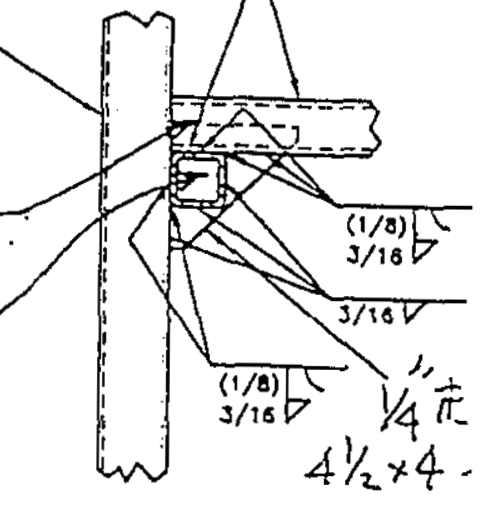

GUSSET TE TRESISTS $\mathrm{M}_{3}$ IN $8 / 4 / 832$

$$
S_{2}=\frac{4.5^{2}}{6}=3.38 \mathrm{cN}^{2} \text { (WELD ONE SIOE ONCY) }
$$

(FOR DERDWEIGHT:) $\left(\mathrm{M}_{2}\right) \mathrm{MAX}=5873 \mathrm{~m} \mathrm{CB}$

$\therefore F_{W}=\frac{5873}{3.38}=1738 \mathrm{LB} / \mathrm{N}<2775$ kLONo6e

(FOR TRANSPORTATION:) (N3.)MAX $=8067 \mathrm{~N} \mathrm{LB}$

$F_{w}=\frac{8067}{3,38}=2387 \mathrm{LB} / \mathrm{W}<2779$ ACDWABCE 
RPP-6018, Rev. 0

ANALYTICAL CALCULATIONS

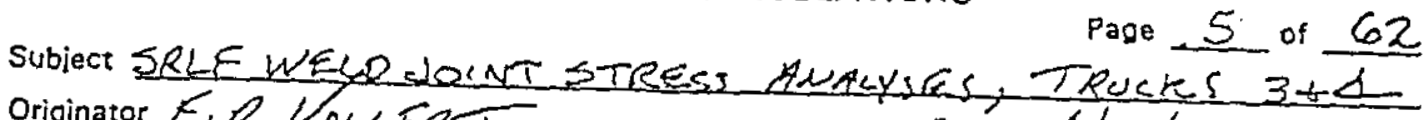
Originator ELP DesERT

Checker Date $41 / 9 / 45$ Date $6-30-9 s$

$$
\cdots
$$

WELD $314 / 832$ TO 32
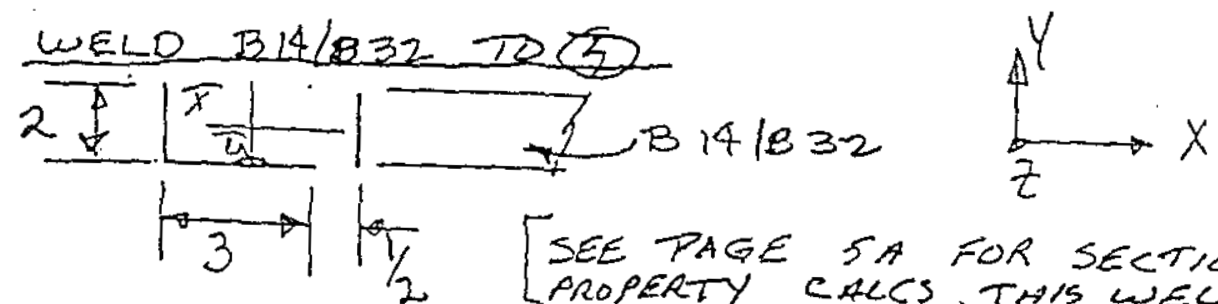

$\left[\begin{array}{l}S E E \text { PAGE SAP FOR SECTION } \\ \text { PROPERTY CALLS, THIS WELD }\end{array}\right]$

$$
\bar{x}=1.64^{\prime \prime}, \bar{y}=0.57^{\prime \prime}, S_{x}=2.131 \mathrm{w}^{2}, S_{y}=7.85 \mathrm{w}=
$$

WELD STRESS $F_{W}=\frac{M_{x}}{S_{x}}+\frac{M_{y}}{5 y}$

$$
F_{w}=\frac{1703}{2.13}+\frac{110}{7.85}=814 \angle B / \mu \alpha<2775<B / 2
$$

for transportatION:)

$$
E_{\omega}=\frac{3336}{2.13}+\frac{5374}{7.85}=2251 \mathrm{LBT} / 2775 \mathrm{cath}
$$

B37/339 TUES) WELDS

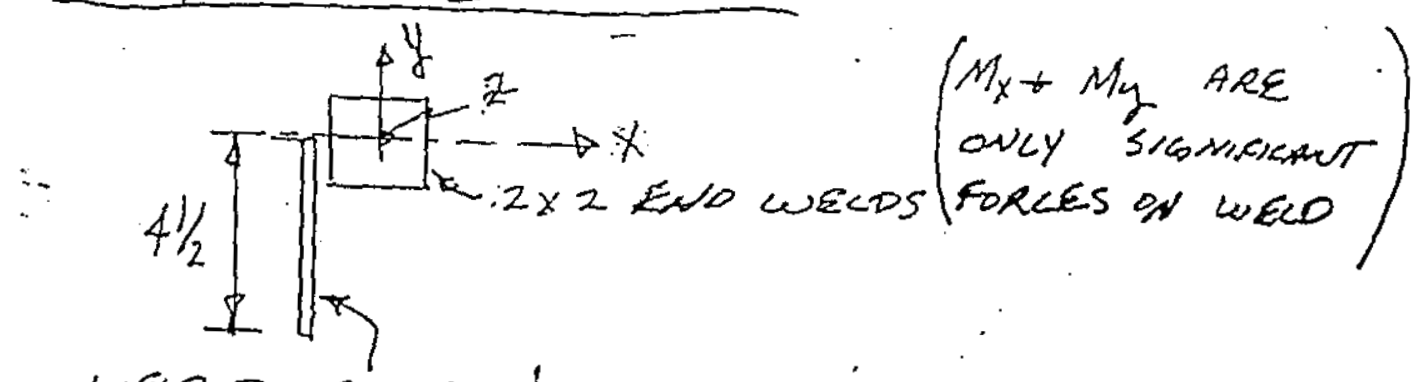

WELO TO GuSSET

$$
\begin{aligned}
& \text { LET } S_{y}=5.33 \mathrm{~N}^{2} \text { (nEGLECT SOSETR) } \\
& \bar{y}=\frac{8 \times 1+4.5 \times 3.25}{12.5}=1,81 \mathrm{NN} \\
& I_{x}=5.33+\frac{4.5^{3}}{12}+4.5(1.44)^{2}+8 \times 0.81^{2}=27.50,10^{3} \\
& S_{x}=27,50 / 3.69=7,45
\end{aligned}
$$

$B-6$

BD -6400-060.3 (07/93)

C-55 
RPP-6018, Rev. 0

ANALYTICAL CALCULATIONS

Page 54 of 62

SUbject SRLEWELO JONUT STRESS ANALYSES, TRUCWS 3 ANO 4 Originator FiR VoLERT Date $6 / 30 / 95$

Checker

Hass $=H .+25 d x$ Date $7-5-25$

SELTION PROPERTIES; WELD B 14/B3I TO 5 (CHAWWE) (REF SKETCA, $P 45$ )

$$
\begin{aligned}
& X=\frac{2 \times 3.5+3 \times 1.5+2 \times 0}{7}=1.64 \mathrm{~N} \\
& I_{y}=\frac{2 \times 2 \times 1+3 \times 0}{1 \times 2}=0.57 \mathrm{~N} \\
& I_{x}=\frac{2 \times 2^{3}}{12}+2 \times 2 \times 0.43^{2}+3 \times 0.57^{2}=3.05 \mathrm{~N}^{3} \\
& S_{x}=\frac{I_{x}}{2-0.57}=\frac{3.05}{1.43}=2.13 \mathrm{~m}^{2} \\
& I_{y}=\frac{3^{3}}{12}+3 \times 0.14^{2}+2 \times 1.64^{2}+2 \times 1.86^{2}=14.61 \mathrm{~m}^{3} \\
& S_{y}=\frac{I_{y}}{1.86}=7.85 \mathrm{w}^{2}
\end{aligned}
$$

$B-7$

BD-6400-060.8 \{07/93\}

C-56 
RPP-6018, Rev. 0

ANALYTICAL CALCULATIONS

Page 6 of 62

SUbject SRLEWELD DOINT STRESI ANACYSES, TRUCKS 3 H

Originator ER, VouEst

Checker

Tase $H$. Znder Date $4 / 0185$ Date $6-30-95$

B37/B39 TO (3) weEOS COUT ruteO

(WED STRESSES)

$\therefore F_{\text {en }}=\frac{M_{x}}{S_{x}}+\frac{M_{y}}{S_{y}}$

(FOR DEAD WEIGAT")

$$
F_{w}=\frac{7065}{7,45}+\frac{223}{5.33}=990<B / 10<2775 \text { CB/m. }
$$

(EOR TRAMBNAKTATION:)

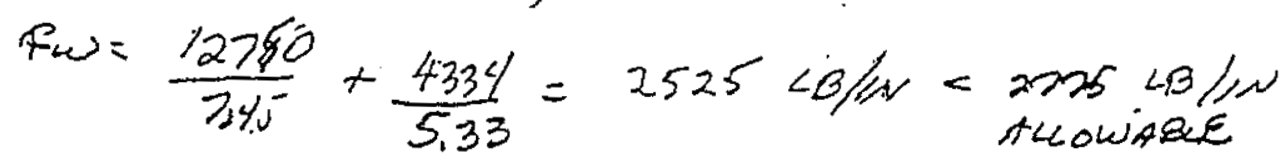

GUSSET R STRESSES

1/4" SUPPORTINS B/4/B32

$\frac{4 y}{4}$ ALONE RESISTS N/3 TeOM B14/332

$4.5+\underset{+1 / 4 \mathbb{R}^{3}}{S_{2}}=\frac{4.5^{2}}{6} \times 0.25=0.84 \mathrm{~m}^{3}$

(DEADWEIGHT)

$$
\left.f_{b}=\frac{5873}{0.84}=6992 \mathrm{PS}\right) .0 K
$$

(Transportation)

$$
f_{0}^{\circ}=\frac{8067}{0.84}=9604 \mathrm{ps} \text { ok }
$$

$B-B$

$B 0.6400 .060 .1(07 / 93)$

C-57 
RPP-6018, Rev. 0

ANALYTICAL CALCULATIONS

Page 7 of 62

SUbject SRLEWELD JOINT STRESS ANNCYSES, TRUCKS $3 \dot{\gamma} 1$ Originator F.R DesERT

Checker

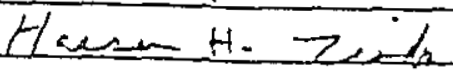
Date $5 / 1 / 4:$ Date $6-30-25$

(3) ANO (3) TO (5) CONTIUULO

GUSSET i STRESSES CONTINUED

$1 / 4$ t Supportive B37/B=9 w ri $2 \times 2 \times 1 / 4$ TUB

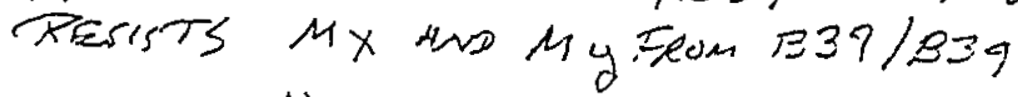

$$
\begin{aligned}
& \begin{array}{l}
4.5 \underbrace{}_{y}=\frac{0.25 \times 4.5 \times 3.25+1.59 \times 1}{1.5970 .25 \times 4.5}=1.93 \mathrm{~N} \\
\bar{x}=\frac{1.59 \times 1}{1.59+0.25 \times 4.5}=0.59 \mathrm{~m}
\end{array} \\
& \begin{array}{l}
I_{x}=0.766+0.766 \times 0.93^{2}+\frac{0.25 \times 4.5^{3}}{12}+4.5 \times 0.25 \times 1.32^{2} \\
I_{x}=5.28 \mathrm{NN}^{4}
\end{array} \\
& I_{y}=7.66+1.59 \times 0.41^{2}+0.25 \times 4.5 \times 0.59^{2}=1.421 \mathrm{~N}^{4}
\end{aligned}
$$

FOR MAX GUSSET te BENDING STRESS:

$$
\begin{aligned}
& S_{y}=\frac{I_{y}}{0.59}=\frac{1.42}{0.59}=2.41 \mathrm{~N}^{3} \\
& S_{x}=\frac{I_{x}}{3.57}=\frac{5.28}{3.57}=1.481 \mathrm{~N}^{3}
\end{aligned}
$$

BENDING STRESS $f_{3}=\frac{M x}{S_{x}}+\frac{M y}{S_{y}}$

$$
f_{b}=\frac{7065}{1.48}+\frac{223}{2,41}=486691 \text { oK }
$$

(TRANSPORTATION)

$$
\begin{aligned}
S_{b}=\frac{12750}{1.48}+\frac{4334}{2.41}=10413 \mathrm{PJ} \text { OK } \\
F_{b}=23760 \mathrm{PS} \text {, ALOW ABLE }
\end{aligned}
$$

$B-9$

$80.6400 .060 .1(07 / 93)$

C-58 


\section{DESIGN CALCULATION}

(1) Drawing H-2-690044

(4) Building

N/A

(2) Doc. No.

(3) Page $8:$ of 62

(7) SubjectCore Sampier Truck Nos 3 \& 4 Shieided Receiver I iffing Ename Assembly

(8) Originator E 3 V a cerct

(9) Checker theseit 7wih Date $4 / 3 / 95$ Date $6-32-5<$

\section{DEAD_WEIGHT_ANAIYSIS}

(Ref. Drawings H-2-690043 and 690044 Sh. 1 \& 2)

WELD JONNT FORCES: GLOBAL COORDINATES MEMBERS(4) ALTUATUR BM TO (3) Frame LIFTING JOINT SKETCH:

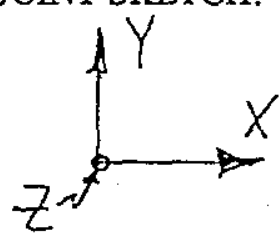

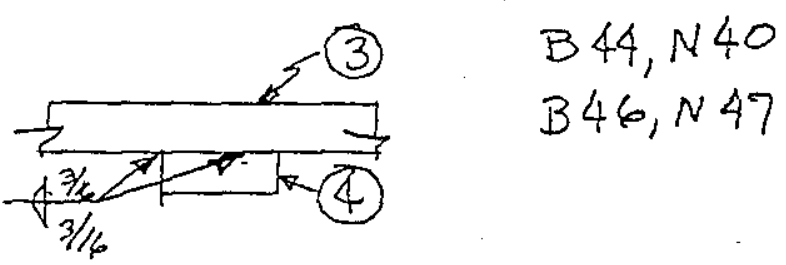

With $\mathrm{Mz}$ Restrained at Nodes 85 and 86

\begin{tabular}{|l|l|l|l|l|l|l|l|}
\hline $\begin{array}{l}\text { Moveable } \\
\text { Frame } \\
\text { Position }\end{array}$ & $\begin{array}{l}\text { Beam and } \\
\text { Node } \\
\text { Numbers }\end{array}$ & $\begin{array}{l}\text { Fx } \\
\text { lbs }\end{array}$ & $\begin{array}{l}\text { Fy } \\
\text { lbs }\end{array}$ & $\begin{array}{l}\text { Fz } \\
\text { Ibs }\end{array}$ & $\begin{array}{l}\text { Mx } \\
\text { in-lbs }\end{array}$ & $\begin{array}{l}\text { My } \\
\text { in-lbs }\end{array}$ & $\begin{array}{l}\text { Mz } \\
\text { in-lbs }\end{array}$ \\
\hline \multirow{2}{*}{$\begin{array}{l}\text { UP } \\
\text { B }\end{array}$} & $B 44, N 40$ & 0 & 1653 & 631 & 5653 & 299 & 2 \\
\hline \multirow{2}{*}{ DOWN } & $B 46, N 49$ & 0 & 1653 & 631 & 5653 & 299 & 2 \\
\hline & $B 460$ & 0 & 1653 & 646 & 5633 & 300 & 1 \\
\hline
\end{tabular}

Without Mz Restrained at Nodes 85 and 86

\begin{tabular}{|l|l|l|l|l|l|l|l|}
\hline $\begin{array}{l}\text { Moveable } \\
\text { Frame } \\
\text { Position }\end{array}$ & $\begin{array}{l}\text { Beam and } \\
\text { Node } \\
\text { Numbers }\end{array}$ & $\begin{array}{l}\mathrm{Fx} \\
\text { lbs }\end{array}$ & $\begin{array}{l}\text { Fy } \\
\text { lbs }\end{array}$ & $\begin{array}{l}\mathrm{Fz} \\
\text { lbs }\end{array}$ & $\begin{array}{l}\mathrm{Mx} \\
\text { in-lbs }\end{array}$ & $\begin{array}{l}\text { My } \\
\text { in-lbs }\end{array}$ & $\begin{array}{l}\mathrm{Mz} \\
\text { in-lbs }\end{array}$ \\
\hline \multirow{3}{*}{ UP } & $B 44, N 40$ & 0 & 1653 & 624 & 5655 & 300 & 2 \\
\cline { 2 - 9 } & $B 46, N 47$ & 0 & 1653 & 624 & 5655 & 300 & 2 \\
\hline \multirow{2}{*}{ DOWN } & $B 44, N 40$ & 0 & 1653 & 647 & 5633 & 300 & 1 \\
\cline { 2 - 8 } & $B 46, N 47$ & 0 & 1653 & 647 & 5633 & 300 & 1 \\
\hline
\end{tabular}




\section{DESIGN CALCULATION}

(1) Drawing H-2-690044

(2) Doc. No.

(3) Page 9 of 62

(4) Building NLA

(5) Rey

(6) Job No.

(7) Subject Core Sampler Truck Nos $3 \& 4$ Shielded Receiver Lifting Erame-Assembly

(8) Originator_E, R Y oeceRT

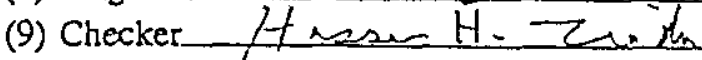
Date 416195 Date $L-i 0-9<$

\section{TRANSPORT LOADS ANATYSIS}

(Ref. Drawings $\mathrm{H}-2-690043$ and 690044 Sh. 1 \& 2)

WEID JOINT FORCES: (Moreable Frame in Down Position)

MEMBERS AS ACTUNTOR BM TO (3) FrameLIETNG

JOINT SKETCH: GLOBAC COWOONATTES
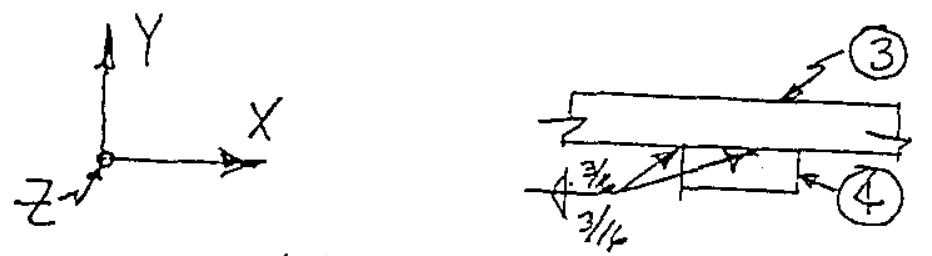

$B 44, N 40$

$B 46, N 47$

With Mz Restrained at Nodes 85 and 86

\begin{tabular}{|c|c|c|c|c|c|c|c|}
\hline $\begin{array}{l}\text { Longitudinal } \\
\text { Load } \\
\text { Direction }\end{array}$ & $\begin{array}{l}\text { Beam and } \\
\text { Node } \\
\text { Numbers }\end{array}$ & $\begin{array}{l}\text { Fx } \\
\text { lbs }\end{array}$ & $\begin{array}{l}\text { Fy } \\
\text { lbs }\end{array}$ & $\begin{array}{l}\mathrm{Fz} \\
\mathrm{Ibs}\end{array}$ & $\begin{array}{l}\text { Mx } \\
\text { in-los }\end{array}$ & $\begin{array}{l}\text { My } \\
\text { in-1bs }\end{array}$ & $\begin{array}{l}\mathrm{Mz} \\
\text { in-lbs }\end{array}$ \\
\hline \multirow{2}{*}{ FORWARD } & 124,140 & 59 & 2319 & 682 & 5616 & 496 & 457 \\
\hline & BUt, NS & 72 & 1584 & 666 & 7538 & 2355 & 457 \\
\hline \multirow{2}{*}{$\begin{array}{l}\text { AFT } \\
\therefore \quad \therefore\end{array}$} & $B C 4, N 40$ & 72 & 2445 & 1245 & 5267 & 1983 & 331 \\
\hline & $B A 6, N<7$ & 54 & 1458 & 1229 & 7911 & 674 & $33 /$ \\
\hline
\end{tabular}

Without Mz Restrained at Nodes 85 and 86

\begin{tabular}{|l|l|l|l|l|l|l|l|}
\hline $\begin{array}{l}\text { Longitudinal } \\
\text { Load } \\
\text { Direction }\end{array}$ & $\begin{array}{l}\text { Beam and } \\
\text { Node } \\
\text { Numbers }\end{array}$ & $\begin{array}{l}\text { Fx } \\
\text { lbs }\end{array}$ & $\begin{array}{l}\text { Fy } \\
\text { lbs }\end{array}$ & $\begin{array}{l}\text { Fz } \\
\text { lbs }\end{array}$ & $\begin{array}{l}\text { Mx } \\
\text { in-lbs }\end{array}$ & $\begin{array}{l}\text { My } \\
\text { in-los }\end{array}$ & $\begin{array}{l}\text { Mz } \\
\text { in-lbs }\end{array}$ \\
\hline FORWARD & $B 44, N 40$ & 62 & 2343 & 605 & 5534 & 494 & 493 \\
\cline { 2 - 9 } & $B 46, N 47$ & 80 & 1560 & 584 & 7684 & 2485 & 493 \\
\hline AFT & $B 44, N 40$ & 72 & 2495 & 1245 & 5271 & $198 / 38$ & 388 \\
\hline
\end{tabular}


RPP-6018, Rev. 0

ANALYTICAL CALCULATIONS

Pape 10 of 62

SUbject SRLFWELD JOINT STAESS ANALYSES, TRWKS $3+4$

Originator E. $e_{1}$ laceet Date $\$ 1 / 195$

Checker Hasan - H.ZWoish

Date $6-30-25$

MEMBERS(4) ALTURTUR BM TO (3) Frame LIFTING

JONNT SKETCH:
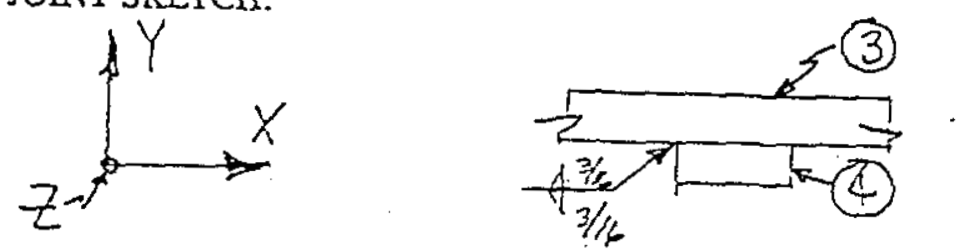

$$
\begin{aligned}
& B 44, N 40 \\
& B 46, N 47
\end{aligned}
$$

MAX WELD FOREES

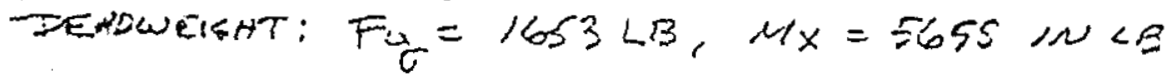

TRANSPORTATION: $F_{y}=1458 \mathrm{CB}, M y=7911 \mathrm{NL}$

WELP JOIXT

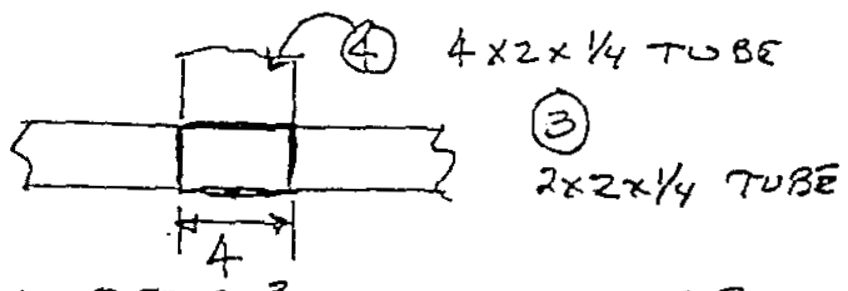

$I_{x}=\frac{2 \times x^{3}}{12}+2 \times 4:=9.33 \frac{4}{12}:, 5_{x}=9.33102$

(WELD STRESSES)

DEADWRISAT

$\therefore F_{w}=\frac{F_{y}}{12}+\frac{M x}{S_{x}}=\frac{1653}{12}+\frac{5655}{9,33}=744 \mathrm{LB} / \omega$

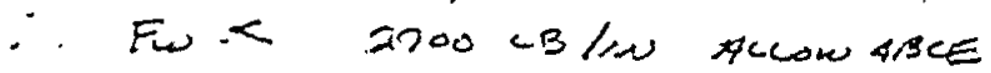

TRANSPURTATTON:

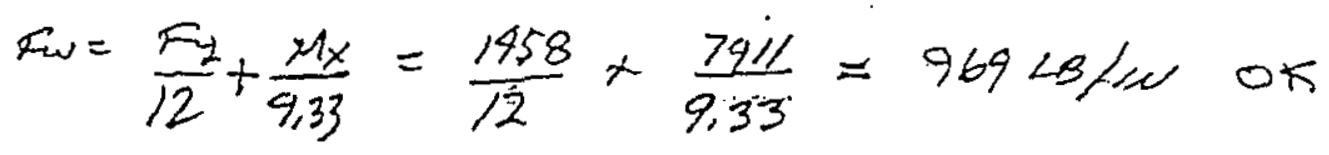

FW $2775 \angle B / I N$ ALCOCUABCE.

$B-12$

$80.8400-060.1(07 / 93)$

C-61 


\section{DESIGN CAICULATION}

(1) Drawing_H-2-690044 (2) Doc. No.

(3) Page 11 of 62

(4) Building N/A

(5) Rev.

(ด) Job No.

(7) Subject Core Sampler Truck Nos 3 \& 4 Shielded Receiver Lifting Exame Assembly

(8) Originator $F \cdot R_{2}$ Voc $\angle R R T$

(9) Checker Hazace H Zaim Date $4 / 3 / 95$ Date $6-30-5 s$

\section{DEAD WETGHT ANALYSTS}

(Ref. Drawings H-2-690043 and 690044 Sh. 1 \& 2)

WELD JOINT FORCES: GLOEAC COXODNATES

MEMBERS (3) TO (3) HID HOR/Z Frame LIETING
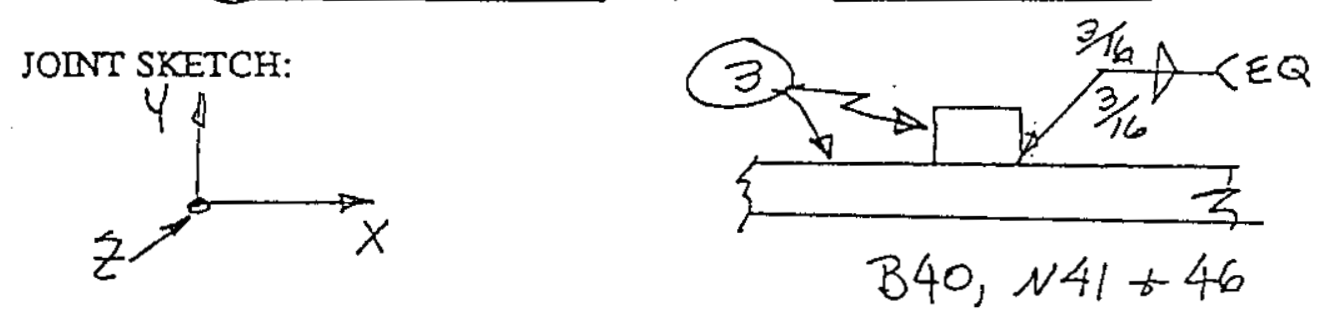

With Mz Restrained at Nodes 85 and 86

\begin{tabular}{|l|l|l|l|l|l|l|l|}
\hline $\begin{array}{l}\text { Moveable } \\
\text { Frame } \\
\text { Position }\end{array}$ & $\begin{array}{l}\text { Beam and } \\
\text { Node } \\
\text { Numbers }\end{array}$ & $\begin{array}{l}\text { Fx } \\
\text { lbs }\end{array}$ & $\begin{array}{l}\text { Fy } \\
\text { lbs }\end{array}$ & $\begin{array}{l}\text { Fz } \\
\text { lbs }\end{array}$ & $\begin{array}{l}\text { Mx } \\
\text { in-lbs }\end{array}$ & $\begin{array}{l}\text { My } \\
\text { in-lbs }\end{array}$ & $\begin{array}{l}\text { Mz } \\
\text { in-lbs }\end{array}$ \\
\hline \multirow{2}{*}{ UP } & B40,N4/ & 0 & 9 & $76 /$ & 205 & 49 & 1 \\
\cline { 2 - 9 } & $340, N 46$ & 0 & 9 & $76 /$ & 205 & 50 & 1 \\
\hline \multirow{2}{*}{ DOWN } & $B 40, N 4 /$ & 0 & 9 & 834 & $2 / 5$ & 49 & 0 \\
\cline { 2 - 9 } & $B 40, N 46$ & 0 & 9 & 834 & 255 & 50 & 0 \\
\hline
\end{tabular}

Without $\mathrm{Mz}$ Restrained at Nodes 85 and 86

\begin{tabular}{|l|l|l|l|l|l|l|l|}
\hline $\begin{array}{l}\text { Moveable } \\
\begin{array}{l}\text { Frame } \\
\text { Position }\end{array}\end{array}$ & $\begin{array}{l}\text { Beam and } \\
\text { Node } \\
\text { Numbers }\end{array}$ & $\begin{array}{l}\text { Fx } \\
\text { lbs }\end{array}$ & $\begin{array}{l}\text { Fy } \\
\text { Ibs }\end{array}$ & $\begin{array}{l}\text { Fz } \\
\text { lbs }\end{array}$ & $\begin{array}{l}\text { Mx } \\
\text { in-lbs }\end{array}$ & $\begin{array}{l}\text { My } \\
\text { in-lbs }\end{array}$ & $\begin{array}{l}\text { Mz } \\
\text { in-lbs }\end{array}$ \\
\hline \multirow{4}{*}{ UP } & $B 40, N 4 /$ & 0 & 9 & 756 & 204 & 49 & 1 \\
\cline { 2 - 9 } & $B 40, N 46$ & 0 & 9 & 756 & 204 & 50 & 1 \\
\hline \multirow{2}{*}{ DOWN } & $B 40, N 41$ & 0 & 9 & 837 & 215 & 49 & 0 \\
\cline { 2 - 9 } & $B 40, N 4 / 6$ & 0 & 9 & 837 & 215 & 50 & 0 \\
\hline
\end{tabular}

$B-13$ 
RPP-6018, Rev. 0

DESIGN CALCULATION

(1) Drawing $\mathrm{H}=2-690044$

(2) Doc. No.

(3) Page 12 of 62

(4) Building NIP (5) Rev. (6) Job No.

(7) Subject Core Sampler Truck Nos 3 \& 4 Shielded Receiver L effing Frame Assembly

(8) Originator ER. VOC ERT

Date 416195

(9) Checker

Han H. Zn rh Date $6-30-95$

TRANSPORT LOADS ANALYSIS

(Ref. Drawings H-2-690043 and 690044 Sh. 1 \& 2)

WELD JOINT FORCES: (Moveable Frame in Down Position)

MEMBERS (3) TO (3) MIO HORIZ Frame LIETING

JOINT SKETCH: GLOBAL COORDINATES
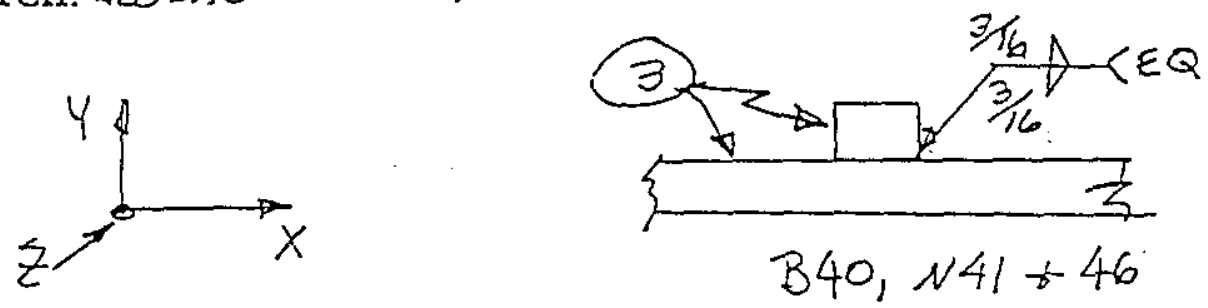

With Mr Restrained at Nodes 85 and 86

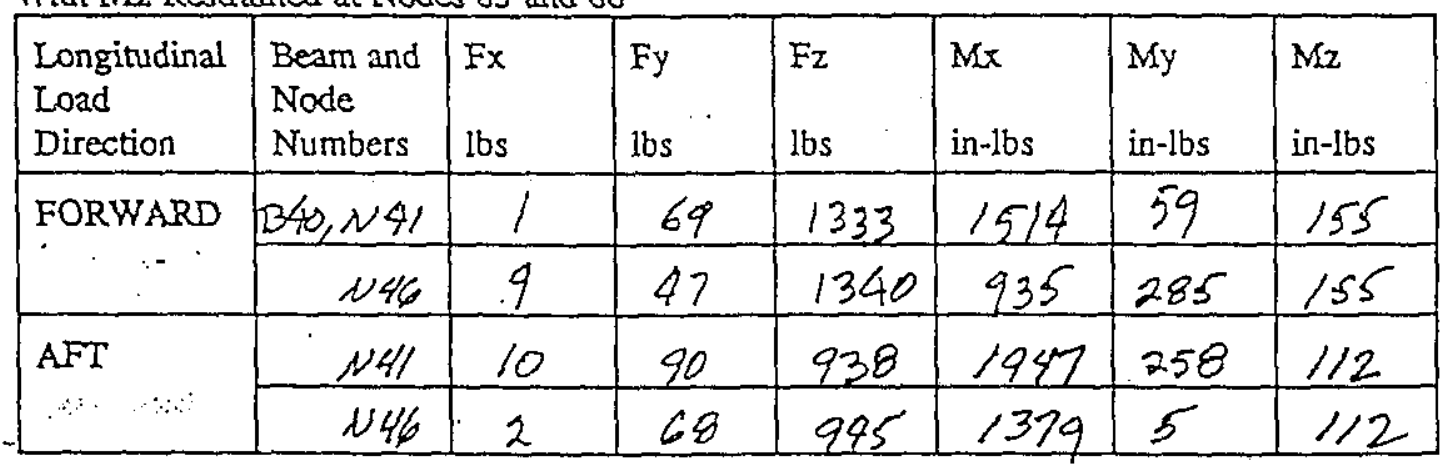

Without Ma Restrained at Nodes 85 and 86

\begin{tabular}{|l|l|l|l|l|l|l|l|}
\hline $\begin{array}{l}\text { Longitudinal } \\
\text { Load } \\
\text { Direction }\end{array}$ & $\begin{array}{l}\text { Beam and } \\
\text { Node } \\
\text { Numbers }\end{array}$ & Ex & Fy & $\begin{array}{l}\text { Fa } \\
\text { lbs }\end{array}$ & $\begin{array}{l}\text { Max } \\
\text { ibs-los }\end{array}$ & $\begin{array}{l}\text { My } \\
\text { in-lbs }\end{array}$ & in -lbs \\
\hline FORWARD & B40,N41 & 1 & 75 & 1244 & 1608 & 69 & 167 \\
\hline \multirow{2}{*}{ AFT } & NHL & 9 & 52 & 1251 & 1062 & 296 & 167 \\
\cline { 2 - 8 } & $N 46$ & 9 & 90 & 937 & 1944 & 242 & 132 \\
\hline
\end{tabular}

$B-14$

C-63 
RPP-6018, Rev. 0

ANALYTICAL CALCULATIONS

Page 13 of 62

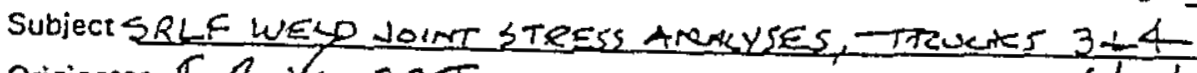
Orioinator E.R. VeceERT

Checker Date $4 / 19 / 95$

Date $6-3=-95$

MEMBERS (3) To (3) WID HOR/Z Frane LIETING JOINT SKETCH:
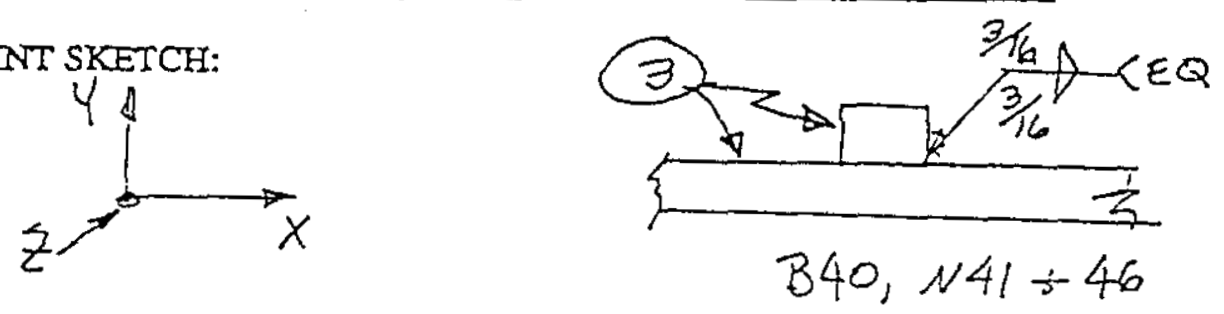

MAXIMUM WRCD FORCES

(DEASUEIGMT) $F_{3}=837 \mathrm{LB}, M_{X}=2 / 5 \mathrm{NL}$

LTRANSPARTATION) $F_{3}=938 \mathrm{cB}, M_{X}=194 \mathrm{~N} \mathrm{NB}$

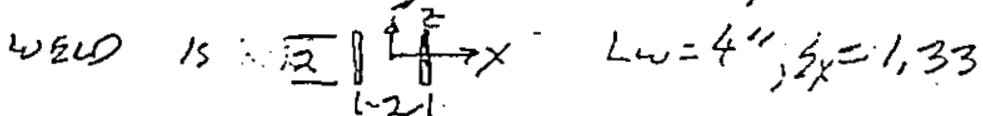

WELD STRESTES

(DEADWE, GHT)

BENDING $F_{w, B}=\frac{M X}{S_{X}}=\frac{215}{/ 33}=162 \mathrm{LB} / \mathrm{N}$

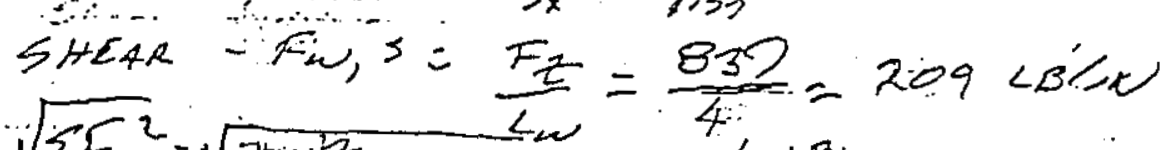

$\sqrt{\sum F_{\omega}^{2}}=\sqrt{762^{2}+209^{2}}=264 \mathrm{LB}=2275 \mathrm{LB} / \mathrm{mon}$

(ERANSPORTATION)

Bendiens $F_{W, B}=\frac{M_{x}}{S_{x}}=\frac{1942}{1,33}=1464 \mathrm{LBH}$

SHEAR $F_{L U S}=\frac{F_{z}}{L w}=\frac{938}{4}=234$

$$
\sqrt{\sum F_{w}^{2}}=\sqrt{1964^{2}+34^{2}}=1978 \frac{\mathrm{LB}}{\mathrm{L}}<.2775 \mathrm{LB} / \mathrm{m}
$$

Puocutere

$B-15$

80.6400-060.1 (07/93)

C- 64 


\section{DESIGN CALCULATION}

(1) Drawing_H-2-690044

(2) Doc. No.

(4) Building__ N/A

(5) Rev

(3) Page 14 of 62

(7) Subject Core Sampler_Truck Nos 3 \& 4 Shielded Receiver I ifting Ename_Assembly

(8) Originator $E R$. KoLLERT

(9) Checker Hacen H. Zunh Date $4 / 4 / 95$

Date $6-30-95$

\section{DEAD WEIGET ANALYSIS}

(Ref. Drawings H-2-690043 and 690044 Sh. 1 \& 2)

WELD JOINT FORCES: GLOBAC COORD NATTES

MEMBERS(3) TO 3 -

JOINI SKETCH:<smiles>CC(C)C[V]</smiles>

With $\mathrm{Mz}$ Restrained at Nodes 85 and 86

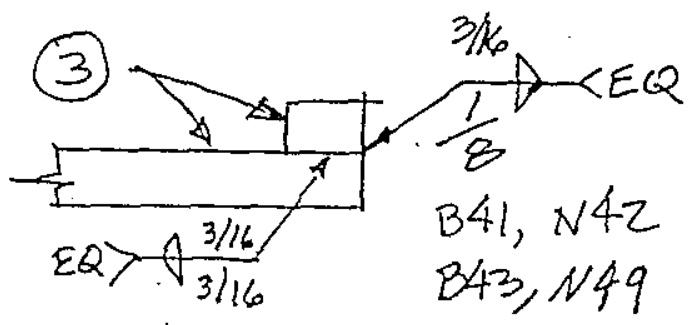

\begin{tabular}{|l|l|l|l|l|l|l|l|}
\hline $\begin{array}{l}\text { Moveable } \\
\text { Frame } \\
\text { Position }\end{array}$ & $\begin{array}{l}\text { Beam and } \\
\text { Node } \\
\text { Numbers }\end{array}$ & $\begin{array}{l}\text { Fx } \\
\text { lbs }\end{array}$ & $\begin{array}{l}\text { Fy } \\
\text { lbs }\end{array}$ & $\begin{array}{l}\text { Fz } \\
\text { lbs }\end{array}$ & $\begin{array}{l}\text { Mx } \\
\text { in-lbs }\end{array}$ & $\begin{array}{l}\text { My } \\
\text { in-lbs }\end{array}$ & $\begin{array}{l}\text { Mz } \\
\text { in-lbs }\end{array}$ \\
\hline UP & $B 41, N 42$ & 0 & 369 & 49 & 1424 & 193 & 1 \\
\hline \multirow{2}{*}{ DOWN } & $B 43, N 49$ & 0 & 369 & 49 & 1424 & 192 & 1 \\
\cline { 2 - 9 } & $B 4 / N 2$ & 0 & 369 & 60 & 1503 & 176 & 0 \\
\hline
\end{tabular}

$\because \cdot \cdot$.

-Without Mz Restrairied at Nodes 85 and 86

\begin{tabular}{|l|l|l|l|l|l|l|l|}
\hline $\begin{array}{l}\text { Moveable } \\
\text { Frame } \\
\text { Position }\end{array}$ & $\begin{array}{l}\text { Beam and } \\
\text { Node } \\
\text { Numbers }\end{array}$ & $\begin{array}{l}\text { Fx } \\
\text { lbs }\end{array}$ & $\begin{array}{l}\text { Fy } \\
\text { lbs }\end{array}$ & $\begin{array}{l}\text { Fz } \\
\text { lbs }\end{array}$ & $\begin{array}{l}\text { Mx } \\
\text { in-lbs }\end{array}$ & $\begin{array}{l}\text { My } \\
\text { in-lbs }\end{array}$ & $\begin{array}{l}\text { Mz } \\
\text { in-lbs }\end{array}$ \\
\hline UP & $B 41, N 42$ & 0 & 369 & 51 & 1423 & 194 & 1 \\
\cline { 2 - 9 } & $B 43, N 49$ & 0 & 369 & 51 & 1425 & 193 & 1 \\
\hline \multirow{2}{*}{ DOWN } & $841, N 42$ & 0 & 369 & 59 & 1504 & 176 & 0 \\
\cline { 2 - 9 } & $843, N 49$ & 0 & 369 & 59 & 1505 & -175 & 0 \\
\hline
\end{tabular}

$$
B-16
$$




\section{DESIGN CALCULATION}

(1) Drawing H-2-690044

(4) Building__ N/A

(2) Doc. No.

(3) Page 15 of 62

(6) Job No

(T) Subject_Core-Sampler Tuck Nos 3 \& 4 Shielded Receiver Liffing Erame_Assembly

(8) Originator E. R. V $6 \mathrm{~L} E \mathrm{ErT}$

(9) Checker

Harsen He Zniln

Dare $4 h / 45$

Date $6-30-95$

TRANSPORT LOADS ANALYSIS

(Ref. Drawings H-2-690043 and 690044 Sh. 1 \& 2)

WELD JOINT FORCES: (Moveable Frame in Down Position)

MEMBERS (3) TO (3) EDSE HORIZCUTH Frame LIPTIN

JOINT SKETCH: GLOBAC COORDNUATES<smiles>[X]C(=C)C1CC1</smiles>

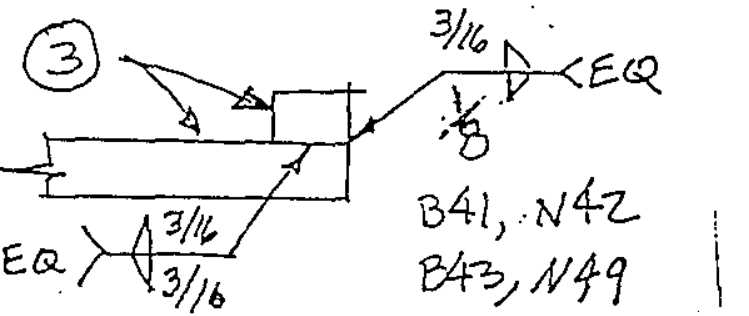

With $\mathrm{Mz}_{2}$ Restrained at Nodes 85 and 86

\begin{tabular}{|l|l|l|l|l|l|l|l|}
\hline $\begin{array}{l}\text { Longitudinal } \\
\text { Load } \\
\text { Direction }\end{array}$ & $\begin{array}{l}\text { Beam and } \\
\text { Node } \\
\text { Numbers }\end{array}$ & $\begin{array}{l}\text { Fx } \\
\text { Ibs }\end{array}$ & $\begin{array}{l}\text { Fy } \\
\text { lbs }\end{array}$ & $\begin{array}{l}\text { Fz } \\
\text { lbs }\end{array}$ & $\begin{array}{l}\text { Mx } \\
\text { in-lbs }\end{array}$ & $\begin{array}{l}\text { My } \\
\text { in-lbs }\end{array}$ & $\begin{array}{l}\text { Mz } \\
\text { in-lbs }\end{array}$ \\
\hline \multirow{2}{*}{ FORWARD } & $B 41, N 42$ & 124 & 423 & 54 & 3022 & 368 & 94 \\
\cline { 2 - 9 } & $B 43, N 49$ & 194 & 269 & 214 & 470 & 1823 & 99 \\
\hline AFT & $B 4, N 42$ & 194 & 589 & 277 & 4263 & 2150 & 32 \\
\hline
\end{tabular}

Without Mz Restrained at Nodes 85 and 86

\begin{tabular}{|c|c|c|c|c|c|c|c|}
\hline $\begin{array}{l}\text { Longitudinal } \\
\text { Load } \\
\text { Direction }\end{array}$ & $\begin{array}{l}\text { Beam and } \\
\text { Node } \\
\text { Numbers }\end{array}$ & $\begin{array}{l}\text { Fx } \\
\text { Ibs }\end{array}$ & $\begin{array}{l}\text { Fy } \\
\text { lbs }\end{array}$ & $\begin{array}{l}\mathrm{Fz} \\
\mathrm{Ibs}\end{array}$ & $\begin{array}{l}\mathrm{Mx} \\
\text { in-lbs }\end{array}$ & $\begin{array}{l}\text { My } \\
\text { in-lbs }\end{array}$ & $\begin{array}{l}\mathrm{Mz} \\
\text { in-Ibs }\end{array}$ \\
\hline \multirow{2}{*}{ FORWARD } & 341,142 & 126 & 429 & 70 & 3067 & 388 & 107 \\
\hline & 343,149 & 191 & 291 & 203 & 650 & 1753 & 107 \\
\hline \multirow[t]{2}{*}{ AFT } & $041, N 42$ & 193 & 591 & 277 & 4290 & 斻 & 51 \\
\hline & $B 43, N 49$ & 125 & 431 & 4 & $1 i 5$ & $70 !$ & 51 \\
\hline
\end{tabular}


RPP-6018, Rev. 0

ANALYTICAL CALCULATIONS

Page 16 of 62

SUbject SRLE WELPUOWT STRESS ANALYSES, TEZEKS $3+$ I

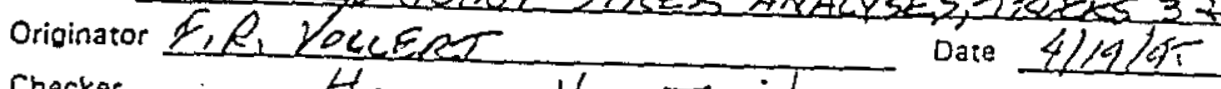

Checker Hassin if. Jiide

Date

$6-2=-31$

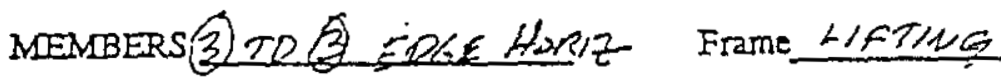

JOINT SKETCH:
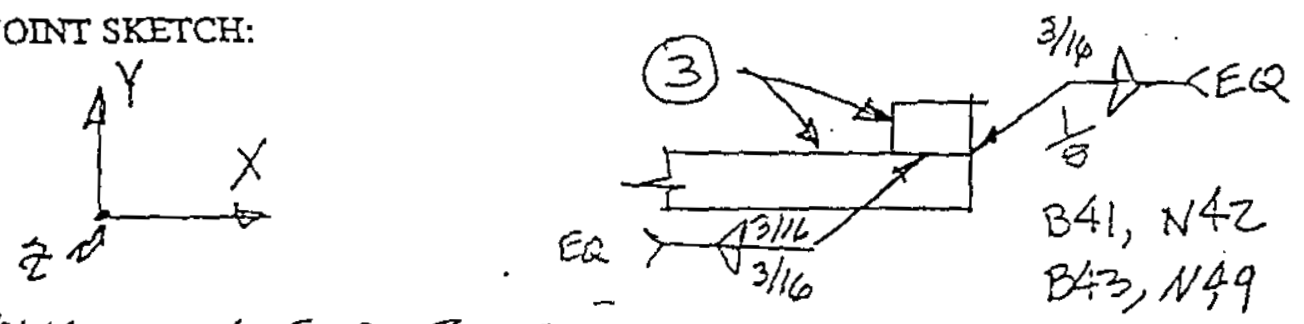

MAXMUM WEDO FORCES

(IENDWEIGNT) $M_{X}=1505 \mathrm{NLB}$

(TRANSPORTATIOE) MX< $4290 \mathrm{NLB}, M_{y}=2 / R / N \angle B$

weio is - $\rightarrow I_{X}=I_{Z}=5.33 \mathrm{~s}^{3}$

$\therefore \quad \frac{12 \mid}{|2|}$

$S_{x}=S_{z}=5,33 w^{2}$

WEIO THKNES

Acowd

WELD STRESES

(TRANSPORTARTION)

$\therefore$ Bending fine $=\frac{M x}{5 x}=\frac{4290}{5.33}=809 \mathrm{LB}$

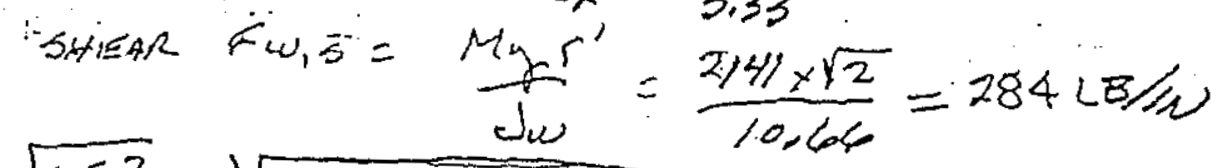

$\sqrt{2 F^{2}}=\sqrt{809^{2}+284^{2}}=857 \mathrm{cB} / \mathrm{L}<2546 \mathrm{LBS}$

Aviow ARE

$B-18$

$80-6400-060.1(07 / 93)$

C-67 


\section{DESIGN CALCULATION}

(1) Drawing_H-2-690044

(4) Building_ N//A

(2) Doc. No.

(3) Page 17 of 62

(7) Subject Core Sampler Truck Nos 3 \& 4 Shielded Receiver Liffing Erame Assembly

(8) Originator ER $V_{e \leq 4 E R T}$

(9) Checker

Hasanom. Haide

Date $4 / 4 / 95^{2}$

Date $\leq-3-3.5$

\section{DEAD WEIGHT ANAIYSIS}

(Ref. Drawings H-2-690043 and 690044 Sh. 1 \& 2)

WELD JOINT FORCES: GLOBAL COORDINATES

MEMBBERS (3) To TOP of (5) Frame LIETINE

JOINT SKETCH:

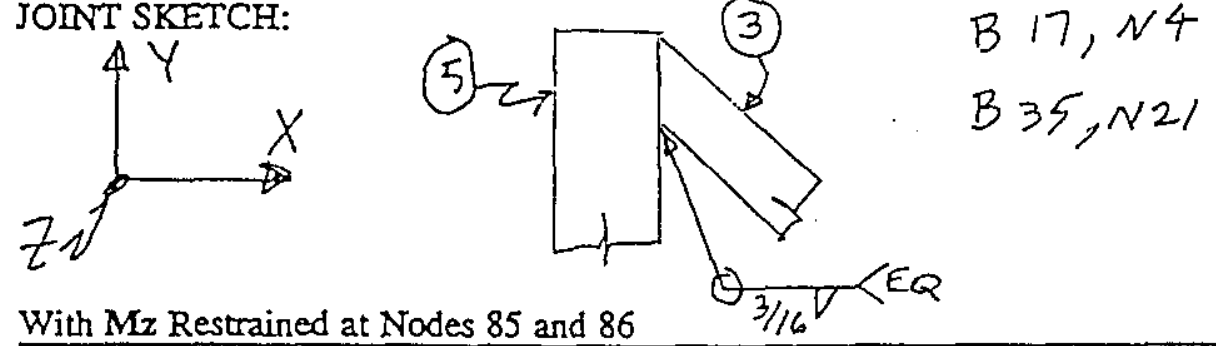

\begin{tabular}{|c|c|c|c|c|c|c|c|}
\hline $\begin{array}{l}\text { Moveable } \\
\text { Frame } \\
\text { Position }\end{array}$ & $\begin{array}{l}\text { Beam and } \\
\text { Node } \\
\text { Numbers }\end{array}$ & $\begin{array}{l}\text { Fx } \\
\text { Ibs }\end{array}$ & $\begin{array}{l}\text { Fy } \\
\text { Ibs }\end{array}$ & $\begin{array}{l}\text { Fz } \\
\text { lbs }\end{array}$ & $\begin{array}{l}M x \\
\text { in-lbs }\end{array}$ & $\begin{array}{l}\text { My } \\
\text { in-lbs }\end{array}$ & $\begin{array}{l}\mathrm{Mz} \\
\text { in-lbs }\end{array}$ \\
\hline \multirow[t]{2}{*}{ UP } & $87, N 4$ & 192 & 56 & 20 & 84 & 396 & 1175 \\
\hline & $B 3, N 2$ & 192 & 56 & 20 & 84 & 396 & 1175 \\
\hline \multirow[t]{2}{*}{ DOWN } & $B \cap, N 4$ & $3 /$ & 108 & 20 & 58 & 336 & 1098 \\
\hline & $335, N 21$ & $3 /$ & 107 & 20 & 58 & 335 & 1099 \\
\hline
\end{tabular}

Without Mz Restrained at Nodes 85 and 86

\begin{tabular}{|l|l|l|l|l|l|l|l|}
\hline $\begin{array}{l}\text { Moveable } \\
\text { Frame } \\
\text { Position }\end{array}$ & $\begin{array}{l}\text { Beam and } \\
\text { Node } \\
\text { Numbers }\end{array}$ & Fx & Fy & Fz & Mx & My & Mz \\
\hline \multirow{3}{*}{ UP } & $B \cap, N 4$ & 193 & 57 & 21 & 93 & 410 & 1173 \\
\cline { 2 - 8 } & $B 35, N 2$ & 193 & 57 & 21 & 93 & 410 & 173 \\
\hline \multirow{2}{*}{ DOWN } & $B 17 N 4$ & 30 & 108 & 19 & 54 & 329 & 1099 \\
\cline { 2 - 8 } & $B 35, N 1$ & 30 & 108 & 19 & 54 & 329 & 1100 \\
\hline
\end{tabular}

$$
B-19
$$


RPP-6018, Rev. 0

DESIGN CALCULATION

(1) Drawing $\mathrm{H}-2-600044$

(2) Doc. No.

(3) Page 18 of 62

(4) Building___ N/A

(5) Rev.

(ด) Job No.

(7) Subject Care Sampler Truck Nos 3 \& 4 Shielded Receiver rifting Frame Assembly

(8) Originator ER, llecuERT Date $4 / 7 / 95$

(9) Checker

tan es H. Lira

Date $6-30-95$

TRANSPORT IOADS_ANATYSIS

(Ref. Drawings H-2-690043 and 690044 Sh. 1 \& 2)

WELD JOINT FORCES: (Moveable Frame in Down Position)

MEMBERS (3) TO TOE of (5)

Frame_LIETING

GLOBAL COORDINATES JOINT SKETCH:
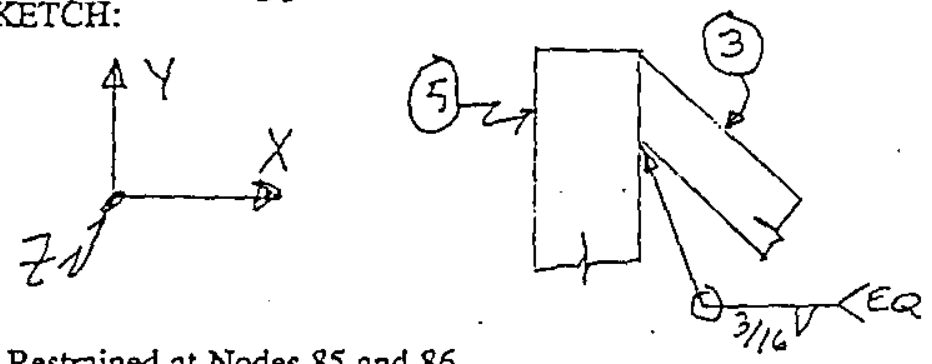

$B 17, N 4$

$B 35, N 21$

With Mr Restrained at Nodes 85 and 86

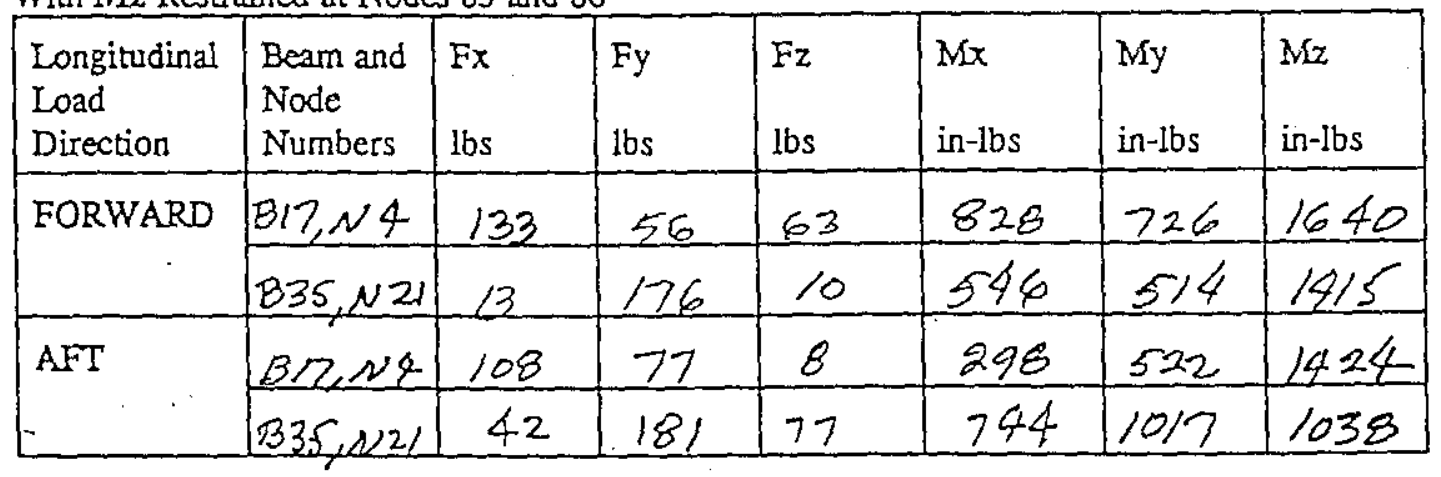

Without $\mathrm{Mz}$ Restrained at Nodes 85 and 86

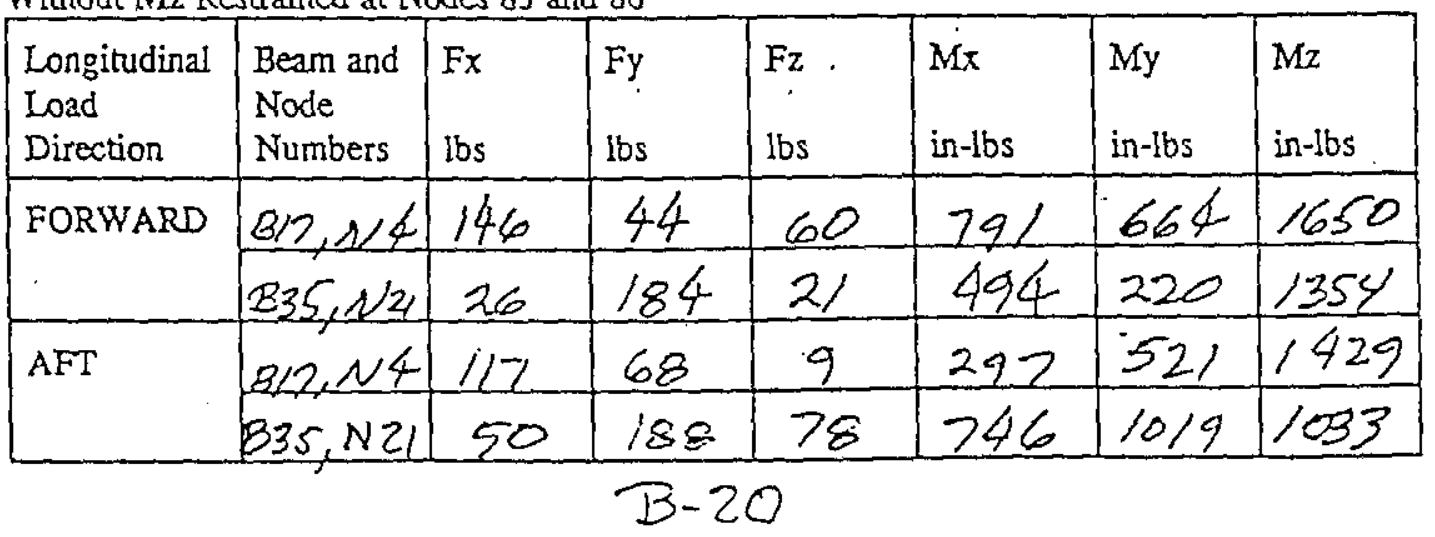

C-69 
RPP-6018, Rev. 0

ANALYTICAL CALCULATIONS

Page 19 of 62

Subject SRLFWELD JONT STRESS ANAREEI, TRZULKS, $3 \times 4$ Originator F.R. KoccERT Date $9 / 20 / 45$

Checker

Hase H. Zrila Date

$6-30-95$

MEMBERS (3) To (2) TOP Frame LIFTING
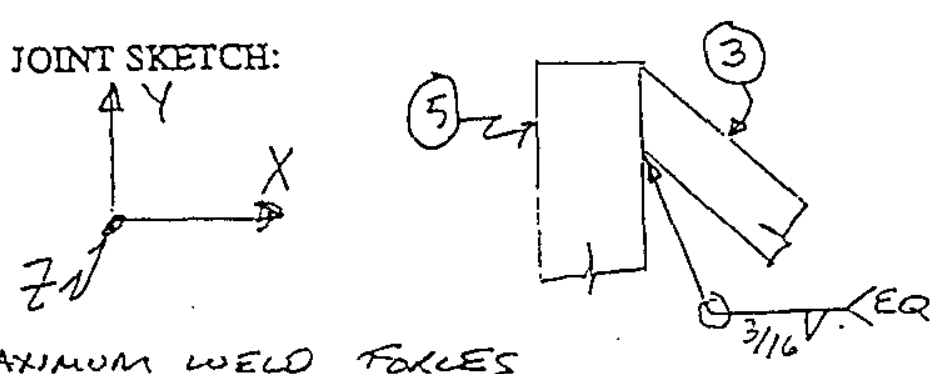

$B 17, N 4$

$B 35, N 21$

MAXMUUM WELO FOKLES

(DEAOWEISAT) Mz $=1175$ NNAB, $M g=396 \mathrm{NM} \angle B$

(RNASPORTATION) $M_{3}=1650 \mathrm{~N} \angle B, M_{y}=664 \mathrm{NLB}, M_{x}=791 \mathrm{mc}$

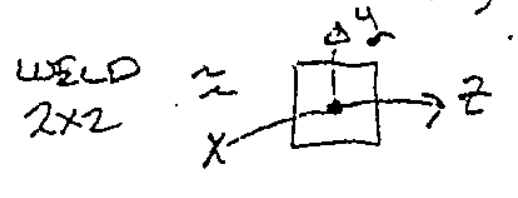

$$
\begin{aligned}
& S_{y}=S_{z}=5.33, J_{w}=10.66 \mathrm{w}^{3} \\
& r^{\prime}=\sqrt{2}
\end{aligned}
$$

WELP STRESSES

(eEADW ElGtT) $F_{w}=\frac{M_{3}+M_{y}}{5.33}=\frac{175+396}{5.33}=295 \mathrm{cg} / \mathrm{m}$

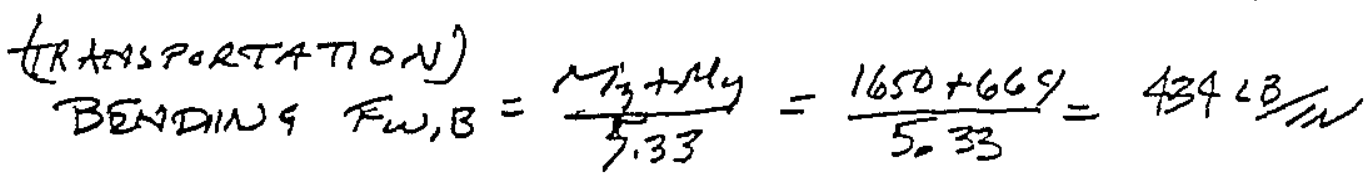

SHEAR Fw, $F_{w}=\frac{M x}{\frac{1}{k}}=\frac{741 \times \sqrt{2}}{10.66}=105 \mathrm{LB} / \mathrm{MN}$

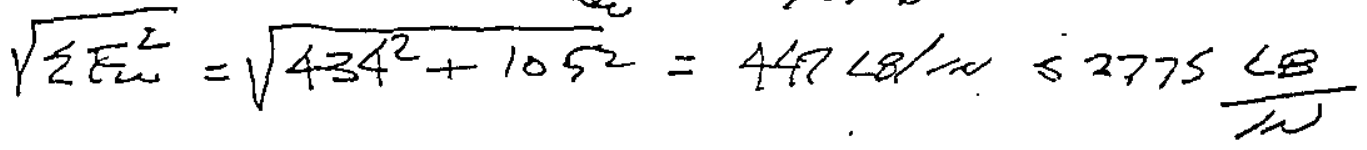

ACLOWHBE

$B-21$

$80-8400-060.1(07 / 93)$

C-70 


\section{DESIGN CALCULATION}
(1) Drawing H-2-690044
(2) Doc. No.
(3) Page 20 of 62
(4) Building__ N/A
(5) Rev.
(6) Jó No
(7) Subject Care Sampler Truck Nos. 3 \& 4_Shielded Receiver Lifting Erame_Assembly
(8) Originator F.R. VoLLERT
(9) Checker
Hacsu
H. Zind
Date $4 / 3 / 95$
Date $6-30-45$

DEAD WEIGHT ANALYSIS

(Ref. Drawings F-2-690043 and 690044 Sh. 1 \& 2)

WEID JONT FORCES: GLOZAL COORDMATES

MEMBERS OTOO (UOOER BRAER)Frame LIETIG

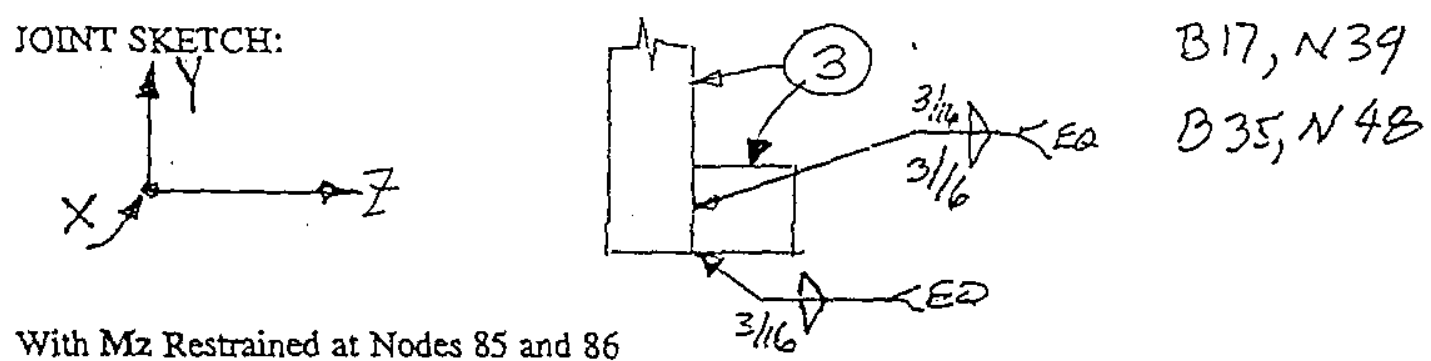

\begin{tabular}{|c|c|c|c|c|c|c|c|}
\hline $\begin{array}{l}\text { Moveable } \\
\text { Frame } \\
\text { Position }\end{array}$ & $\begin{array}{l}\text { Bearn and } \\
\text { Node } \\
\text { Numbers }\end{array}$ & Fx & $\begin{array}{l}\text { Fy } \\
\text { lbs }\end{array}$ & $\begin{array}{l}F z \\
\text { lbs }\end{array}$ & $\begin{array}{l}M x \\
\text { in-lbs }\end{array}$ & $\begin{array}{l}\text { My } \\
\text { in-lbs }\end{array}$ & $\begin{array}{l}\mathrm{Mz} \\
\mathrm{in}-\mathrm{lbs}\end{array}$ \\
\hline \multirow{2}{*}{$\begin{array}{l}\text { UP } \\
\vdots-\end{array}$} & $B 17 \times 39$ & 192 & 44 & 20 & 350 & 19 & 1979 \\
\hline & $B 35, N 48$ & 192 & 44 & 20 & 350 & 19 & 1429 \\
\hline \multirow[t]{2}{*}{ DOWN } & $B 17, N 31$ & 31 & 120 & 20 & 378 & 19 & 1947 \\
\hline & $835,1 \times 48$ & 31 & 120 & 20 & 376 & 79 & 1947 \\
\hline
\end{tabular}

Without Mz Restrained at Nodes 85 and 86

\begin{tabular}{|c|c|c|c|c|c|c|c|}
\hline $\begin{array}{l}\text { Moveable } \\
\text { Frame } \\
\text { Position } \\
\end{array}$ & $\begin{array}{l}\text { Beam and } \\
\text { Node } \\
\text { Numbers }\end{array}$ & $\begin{array}{l}\text { Ex } \\
\text { lbs }\end{array}$ & Fy & Fz & $\begin{array}{l}\mathrm{Mx} \\
\text { in-lbs }\end{array}$ & $\begin{array}{l}\text { My } \\
\text { in-lbs }\end{array}$ & $\begin{array}{l}\mathrm{Mz} \\
\mathrm{in}-\mathrm{lbs}\end{array}$ \\
\hline \multirow[t]{2}{*}{ UP } & $3 \cap, 2,29$ & 193 & 45 & 2) & 364 & 27 & 1978 \\
\hline & $335, N 48$ & 193 & 45 & 21 & 364 & 27 & 1978 \\
\hline \multirow[t]{2}{*}{ DOWN } & $B D, N B A$ & 30 & 120 & 19 & 362 & 75 & 1947 \\
\hline & 335,448 & 30 & 120 & 19 & 369 & 75 & 1948 \\
\hline
\end{tabular}

$B-22$ 


\section{DESIGN CALCULATION}
(1) Drawing H-2-690044
(2) Doc. No.
(3) Page 21 of 62
(4) Building
Nla
(5) Rev
(6) Job No
(7) Subject Core Sampier Truck Nos 3 \& 4 Shielded Receiver I ifting Erame Assembly
(8) Originator F.R $V_{0<} \in R T$ Date $4 \operatorname{ls} / 95$
(9) Checker Hassen H. Zish Date $6-30-95$

\section{TRANSPORT IOADS ANALYYSTS}

(Ref. Drawings H-2-690043 and 690044 Sh. 1 \& 2)

WELD JOINT FORCES: (Moveable Frame in Down Position) MEMBERS (3) TO (3) (UPPER BRACE) Frame LIFTING

JOINT SKETCH: GLOBAL COORDUATES

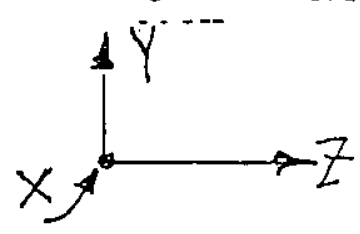

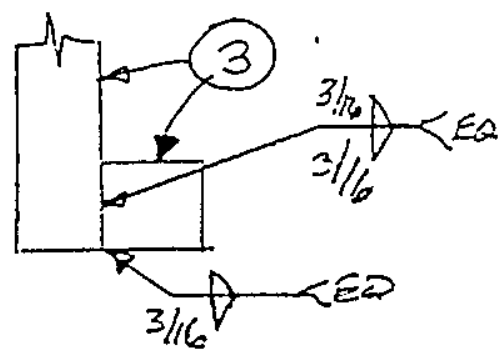

$B 17, N 39$ $B 35, N 48$

With $\mathrm{Mz}$ Restrained at Nodes 85 and 86

\begin{tabular}{|c|c|c|c|c|c|c|c|}
\hline $\begin{array}{l}\text { Longitudinal } \\
\text { Load } \\
\text { Direction }\end{array}$ & $\begin{array}{l}\text { Beam and } \\
\text { Node } \\
\text { Numbers }\end{array}$ & Ibs & $\begin{array}{l}\text { Fy } \\
\text { lbs }\end{array}$ & $\begin{array}{l}\mathrm{Fz} \\
\mathrm{lbs}\end{array}$ & $\begin{array}{l}\text { Mx } \\
\text { in-lbs }\end{array}$ & $\begin{array}{l}\text { My } \\
\text { in-lbs }\end{array}$ & $\begin{array}{l}\mathrm{Mz} \\
\text { in-lbs }\end{array}$ \\
\hline \multirow{2}{*}{$\begin{array}{l}\text { FORWARD } \\
\end{array}$} & $B 17, N 39$ & 128 & 70 & 68 & 611 & 648 & 2550 \\
\hline & $B 35, N 48$ & 18 & 190 & 6 & 366 & 342 & 2078 \\
\hline \multirow{2}{*}{$\begin{array}{l}\text { AFT } \\
\vdots\end{array}$} & $3 n, 439$ & $1 / 3$ & 91 & 13 & 520 & 734 & 2745 \\
\hline & 335,198 & 37 & 196 & 82 & 998 & 646 & 2021 \\
\hline
\end{tabular}

Without Mz Restrained at Nodes 85 and 86

\begin{tabular}{|l|l|l|l|l|l|l|l|}
\hline $\begin{array}{l}\text { Longitudinal } \\
\text { Lodd } \\
\text { Direction }\end{array}$ & $\begin{array}{l}\text { Beam and } \\
\text { Node } \\
\text { Numbers }\end{array}$ & $\begin{array}{l}\text { Fx } \\
\text { lbs }\end{array}$ & $\begin{array}{l}\text { Fy } \\
\text { lbs }\end{array}$ & $\begin{array}{l}\text { Fz. } \\
\text { lbs }\end{array}$ & $\begin{array}{l}\text { Mx } \\
\text { in-lbs }\end{array}$ & $\begin{array}{l}\text { My } \\
\text { in-lbs }\end{array}$ & $\begin{array}{l}\mathrm{Mz} \\
\text { in-lbs }\end{array}$ \\
\hline FORWARD & $B 17, N 39$ & 141 & 59 & 65 & 582 & 646 & 2580 \\
\cline { 2 - 9 } & $335, N 48$ & 32 & 199 & 26 & 1007 & 710 & 2020 \\
\hline \multirow{2}{*}{ AFT } & $81, N 39$ & 122 & 82 & 13 & 531 & 744 & 2749 \\
\cline { 2 - 8 } & $1334, N 4 B$ & 44 & 203 & 82 & 1008 & 655 & 2017 \\
\hline
\end{tabular}


RPP-6018, Rev. 0

ANALYTICAL CALCULATIONS

Page 22 of 62

SUbject SRLE WELO JON STHESS HNALYSES, TRUCHS, $3+4$

Originator ER $E_{1}$ loce $E R T$

Checker $H=0=1 \mathrm{~T}=\mathrm{sid}$ Date $4 / 19 / 45$

Date $-6-30-95$

MEMBERS OTO (UPOER BRACE) Frame LIETING
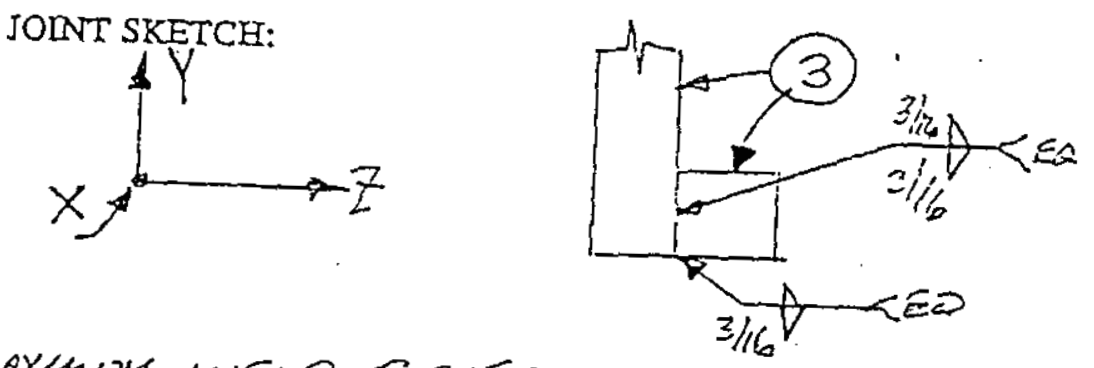

$B 17, N 39$

$B 35, N 48$

MAKMUN UUELO FOREES

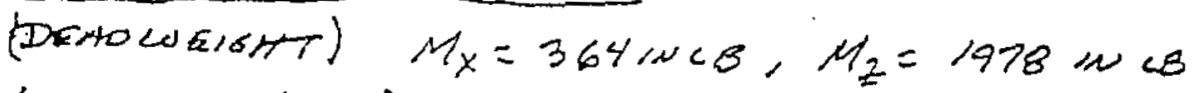

(TRANEPORTATROA) $M_{X}=531 \mathrm{NLB}, M_{y}=744 \mathrm{NLB}, M_{z}=2749 \mathrm{NCE}$

WELP SKETCW

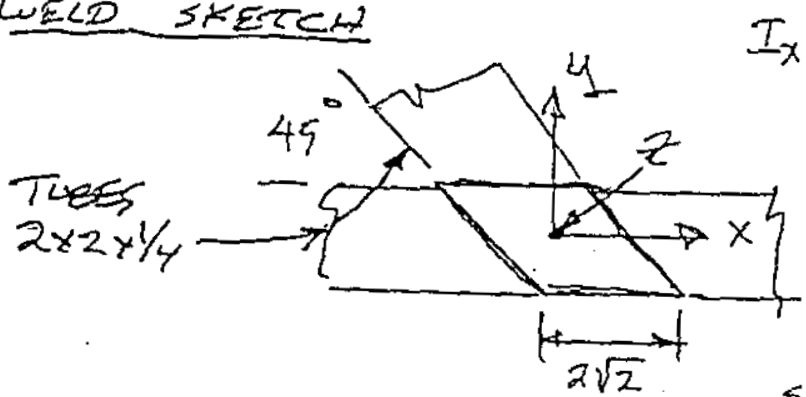

$I_{\omega}=18.81 \mathrm{w}^{3}$

$I_{x}=\frac{2 \times 2^{3}}{S_{x}^{2}}=7,0 \times 2 \sqrt{2}(1)^{2}=7,0 \mathrm{NN}^{3}$
$S^{2}$

$r=\sqrt{1^{2}+(1+\sqrt{2})^{2}}=2.6 / N$

$I_{y}=\frac{(2 \sqrt{2})^{3}(2)}{12}+2 \times 2(\sqrt{2})^{2}$

WELO STRESSES

(DEAOWETHT)

Bempina, $F_{\omega, B}=\frac{M x}{S_{X}}=\frac{364}{7}=52 \mathrm{ce} / x$

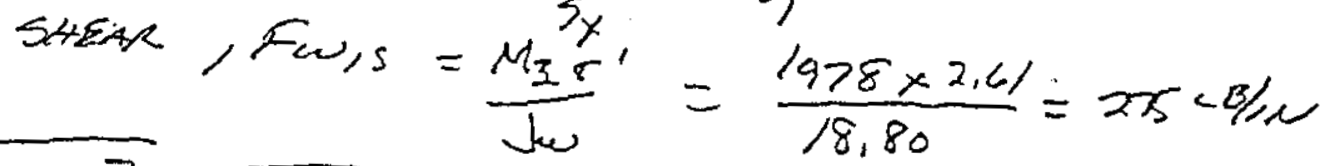

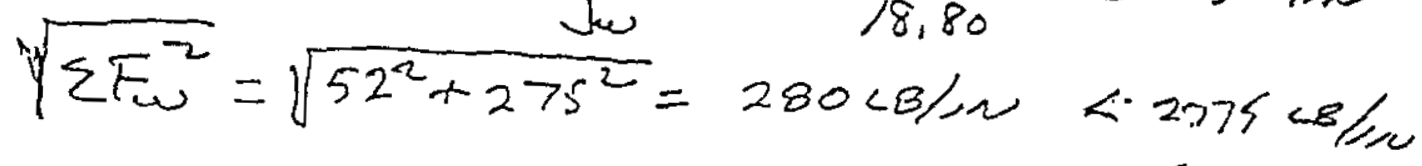

मिय

B-24

100-6400-060.1(07/93)

C-73 
RPP-6018, Rev. 0

ANALYTICAL CALCULATIONS

Page 23 of 62

SUbject SRLE WELO JOINT STRESS ANAVYES, TUPWEKS 304 Originator F.R. VoceERT Date $4 / 19 / 95$ Checker H.H. Zuidu Date $6-30-9 s$

(3) TO(3) (UPPER), WELD STRESSES, CONTINLEO (TRANSPORTIATION)

Renows $F_{\text {res, }}=\frac{M x}{S_{x}}+\frac{M y}{S_{y}}=\frac{531}{7,0}+\frac{74 y}{4,9}=228 \mathrm{co}$

SHEAR $F_{\infty, s}=\frac{M_{Z} S^{\prime}}{\omega}=\frac{2479 \times 2.61}{18.8}=344 \mathrm{ce} / \mathrm{s}$

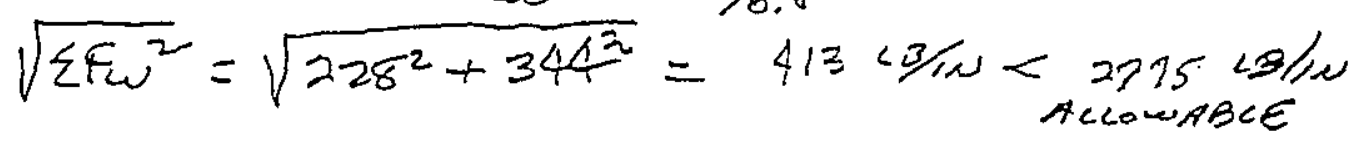

$B-25$

BD. 8400-060.1 (07/93)

C-74 


\section{DESIGN CALCULATTON}
(1) Drawing H-2-690044
(2) Doc. No.
(3) Page 24 of 62
(4) Building _ N/A
(5) Rev
(ब) Job No.
(7) Subject_Core Sampler Truck Nos 3 \& 4 Shielded Receiver Lifting Erame A ssembly
(8) Originator - E. R. L lus E E T
(9) Checker Hasen Date $4 / 3 / 95$
Date $6-3 n-25$

\section{DEAD WEIGHT ANATYSTS}

(Ref. Drawings H-2-690043 and 690044 Sh. 1 \& 2)

WEID JONT FORCES: GLOBR COORDINATES

MEMBERS (3) TO (3) VERT PRAK Frame LIFTING

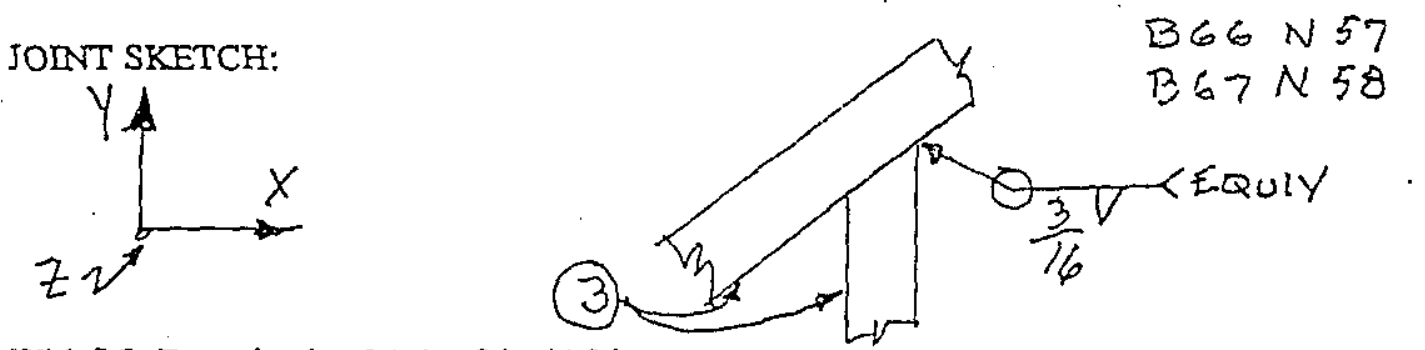

With Mz Restrained at Nodes 85 and 86

\begin{tabular}{|c|c|c|c|c|c|c|c|}
\hline $\begin{array}{l}\text { Moveable } \\
\text { Frame } \\
\text { Position }\end{array}$ & $\begin{array}{l}\text { Beam and } \\
\text { Node } \\
\text { Numbers }\end{array}$ & $\begin{array}{l}\text { Fx } \\
\text { los }\end{array}$ & $\begin{array}{l}\text { Fy } \\
\text { lbs }\end{array}$ & $\begin{array}{l}\text { Fz } \\
\text { los }\end{array}$ & $\begin{array}{l}\text { Mx } \\
\text { in-lbs }\end{array}$ & $\begin{array}{l}\text { My } \\
\text { in-libs }\end{array}$ & $\begin{array}{l}\text { Mz } \\
\text { in-lbs }\end{array}$ \\
\hline \multirow{2}{*}{$\begin{array}{c}\text { UP } \\
:\end{array}$} & $366, \times 57$ & 11 & 121 & 23 & 522 & 63 & $\% 16$ \\
\hline & $267 \wedge 58$ & 11 & 120 & 23 & 523 & 64 & 115 \\
\hline \multirow[t]{2}{*}{ DOWN } & $B \in 60,057$ & $z$ & 60 & 18 & 431 & 25 & 99 \\
\hline & $\mid B 67, N 5 B$ & $z$ & 60 & 18 & 431 & 26 & 99 \\
\hline
\end{tabular}

Without Mz Restrained at Nodes 85 and 86

\begin{tabular}{|c|c|c|c|c|c|c|c|}
\hline $\begin{array}{l}\text { Moveable } \\
\text { Frame } \\
\text { Position }\end{array}$ & $\begin{array}{l}\text { Beam and } \\
\text { Node } \\
\text { Numbers }\end{array}$ & $\begin{array}{l}\text { Fx } \\
\text { lbs }\end{array}$ & $\begin{array}{l}\text { Fy } \\
\text { lbs }\end{array}$ & $\begin{array}{l}\text { Fz } \\
\text { lbs }\end{array}$ & $\begin{array}{l}M x \\
\text { in - Ibs }\end{array}$ & $\begin{array}{l}\text { My } \\
\text { in-lbs }\end{array}$ & $\begin{array}{l}\mathrm{Mz} \\
\text { in-lbs }\end{array}$ \\
\hline \multirow[t]{2}{*}{ UP } & $B 66 N 57$ & 11 & 120 & 24 & 529 & 75 & 114 \\
\hline & $B 67, N 58$ & 11 & 120 & 24 & 530 & 76 & 113 \\
\hline \multirow[t]{2}{*}{ DOWN } & $B 66,2 \leq 7$ & 2 & 60 & 18 & 427 & 19 & 98 \\
\hline & $B 67, N \leq 8$ & 2 & 60 & 18 & 428 & 20 & 97 \\
\hline
\end{tabular}




\section{DESIGN CALCULATION}

(1) Drawing_H-2-690044

(2) Doc. No.

(3) Page 25 of 62

(4) Building

NIA

(5) Rev

(6) Job No

(7) Subject Core Sampler Tnuck Nos 3 \& 4 Shielded Receiver Lifting Erame Assembly

(8) Originator F.R, $\backslash C L E E R T$

(9) Checker Hasen H. Heda

\section{IRANSPORT YOADS ANALYSIS}

(Ref. Drawings F-2-690043 and 690044 Si. 1 \& 2)

WEID JOINT FORCES: (Moreable Frame in Down Position)

MIEMBERS (3) TO (3) VERT ERACE Frame LIFTING

JOINT SKETCH: GLOBAL C OOROINATES

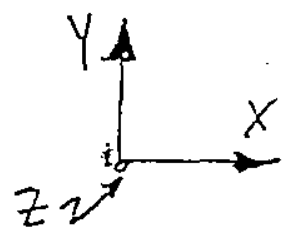

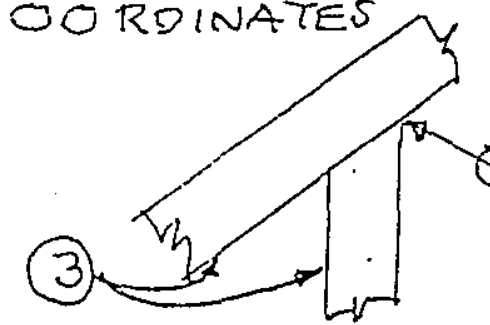

$B 66 N 57$ $B 67 N 58$

With $\mathrm{Mz}$ Restrained at Nodes 85 and 86

\begin{tabular}{|l|l|l|l|l|l|l|l|}
\hline $\begin{array}{l}\text { Longitudinal } \\
\text { Lod } \\
\text { Direction }\end{array}$ & $\begin{array}{l}\text { Beam and } \\
\text { Node } \\
\text { Numbers }\end{array}$ & $\begin{array}{l}\text { Fx } \\
\text { lbs }\end{array}$ & $\begin{array}{l}\text { Fy } \\
\text { lbs }\end{array}$ & $\begin{array}{l}\text { Fz } \\
\text { lbs }\end{array}$ & $\begin{array}{l}\text { Mx } \\
\text { in-lbs }\end{array}$ & $\begin{array}{l}\text { My } \\
\text { in-lbs }\end{array}$ & $\begin{array}{l}\text { Mz } \\
\text { in-lbs }\end{array}$ \\
\hline FORWARD & $B 66, N 57$ & 5 & 242 & 122 & 1241 & 52 & 123 \\
\hline & $B 67, N 58$ & 20 & 135 & 111 & 605 & 250 & 419 \\
\hline \begin{tabular}{l} 
AFT \\
\hdashline
\end{tabular} & E66,N57 & 15 & 298 & 136 & 1082 & 47 & 188 \\
\cline { 2 - 8 } & $1867, N 58$ & 10 & 104 & 113 & 637 & 162 & 336 \\
\hline
\end{tabular}

Without Mz Restrained at Nodes 85 and 86

\begin{tabular}{|c|c|c|c|c|c|c|c|}
\hline $\begin{array}{l}\text { Longitudinal } \\
\text { Load } \\
\text { Direction }\end{array}$ & $\begin{array}{l}\text { Beam and } \\
\text { Node } \\
\text { Numbers }\end{array}$ & $\begin{array}{l}\text { Fx } \\
\text { lbs }\end{array}$ & $\begin{array}{l}\text { Fy } \\
\text { lbs }\end{array}$ & Fz & $\begin{array}{l}M x \\
\text { in-lbs }\end{array}$ & $\begin{array}{l}\text { My } \\
\text { in-lbs }\end{array}$ & $\begin{array}{l}\mathrm{Mz} \\
\mathrm{in}-\mathrm{lbs}\end{array}$ \\
\hline \multirow[t]{2}{*}{ FORWARD } & $B 66, \times<57$ & 3 & 235 & 123 & 1260 & 36 & 96 \\
\hline & 367 NSB & 19 & 133 & 99 & 417 & 212 & 401 \\
\hline \multirow{2}{*}{$\begin{array}{c}\mathrm{AFT} \\
. .\end{array}$} & $B 66, N S 7$ & 15 & 30.1 & 138 & 1094 & 63 & 190 \\
\hline & $B 67, N \leq 8$ & 9 & 107 & 114 & 649 & 178 & 339 \\
\hline
\end{tabular}


RPP-6018, Rev. 0

ANALYTICAL CALCULATIONS

Page 26 of 62

Subject SRLE W/EUR dOINT STRESS RNACVSES, TRRUKS 384 Originator E, PIVOCLET

Checker

Haase H. Ziside oare $\frac{4119495}{6150}$ Date $6-20-95$

MEMIBERS (3) TO (3) VEAT BRAE Frame LIFTING

JOINT SKETCH:
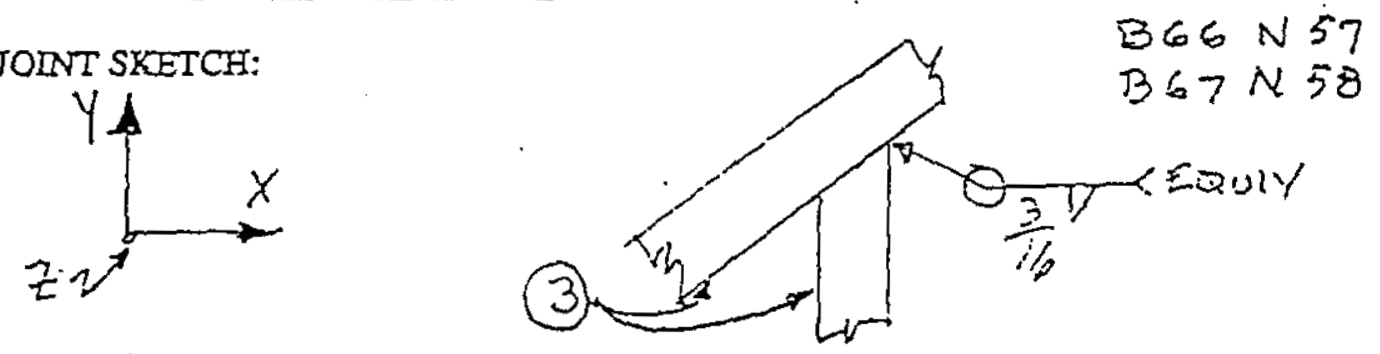

MAXIMUN WENO RORCES

(oErowisith) $M_{X}=530 \mathrm{~N} \angle B$

(TranspoRtatiou) $M_{X}=1260 \mathrm{NL}$

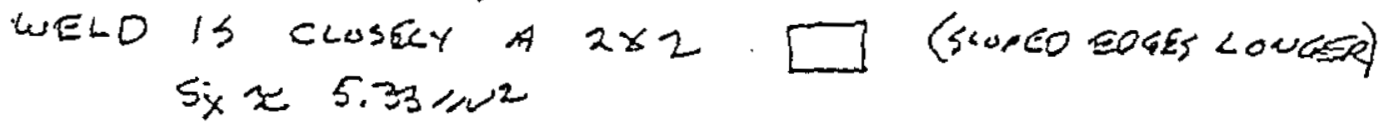

W/ELO STRESSES

DEADWE(GAT) $F_{w}=\frac{M_{x}}{S_{x}}=100 \mathrm{LB} / \mathrm{in}$ OK

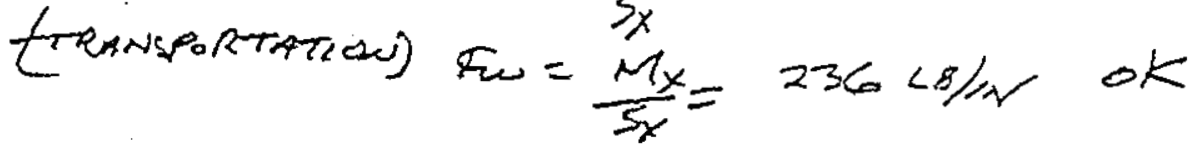

$B-28$

80.6400-060.1 (07/93!

C-77 


\section{DESIGN CALCULATION}
(1) Drawing H-2-690044
(2) Doc. No.
(3) Page 2] of 62
(4) Building
NLA
(5) Rev
(6) Job No.
(7) Subject_Core Sampler Tarck Nos 3\&4SShielded Receiver Lifting Erame, Assembly
(8) Originator_F. R, lneceRT
(9) Checker Hasers
$H \cdot$ Zisida

DEAD WETGHT ANATYSTS

(Ref. Drawings E-2-690043 and 690044 Sh. 1 \& 2)

WELD JOINT FORCES: GLOZAL COORPINATES

MEMBERS (3) TO (3) LOWER RRHEFTame LIFTING

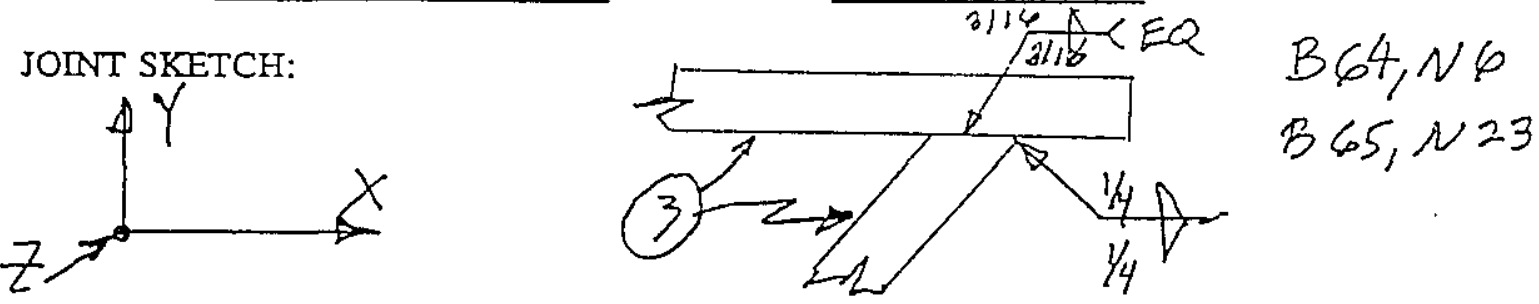

With Mz Restrained at Nodes 85 and 86

\begin{tabular}{|c|c|c|c|c|c|c|c|}
\hline $\begin{array}{l}\text { Moveable } \\
\text { Frame } \\
\text { Position }\end{array}$ & $\begin{array}{l}\text { Beam and } \\
\text { Node } \\
\text { Numbers }\end{array}$ & $\begin{array}{l}\text { Fx } \\
\text { lbs }\end{array}$ & $\begin{array}{l}\text { Fy } \\
\text { lbs }\end{array}$ & $\begin{array}{l}\text { Fz } \\
\text { Ibs }\end{array}$ & in & $\begin{array}{l}\text { My } \\
\text { in-lbs }\end{array}$ & $\begin{array}{l}\mathrm{Mz} \\
\text { in-lbs }\end{array}$ \\
\hline \multirow[t]{2}{*}{ UP } & $B 64, N 6$ & 19 & 215 & 12 & 789 & $1 / 5$ & 1443 \\
\hline & $B 65, N 23$ & 19 & 214 & 12 & 790 & 116 & 1493 \\
\hline \multirow[t]{2}{*}{ DOWN } & B6t, No & 49 & 24 & 8 & 657 & 67 & 1263 \\
\hline & $B 65, \cup Z 3$ & 49 & 24 & 8 & 658 & 67 & 1263 \\
\hline
\end{tabular}

Without Mz Restrained at Nodes 85 and 86

\begin{tabular}{|c|c|c|c|c|c|c|c|}
\hline $\begin{array}{l}\text { Moveable } \\
\text { Frame } \\
\text { Position }\end{array}$ & $\begin{array}{l}\text { Beam and } \\
\text { Node } \\
\text { Numbers }\end{array}$ & Fx & $\begin{array}{l}\text { Fy } \\
\text { lbs }\end{array}$ & $\begin{array}{l}\mathrm{Fz} \\
\mathrm{lbs}\end{array}$ & $\begin{array}{l}M x \\
\text { in-lbs }\end{array}$ & $\begin{array}{l}\text { My } \\
\text { in-lbs }\end{array}$ & $\begin{array}{l}\mathrm{Mz} \\
\text { in-lbs }\end{array}$ \\
\hline \multirow[t]{2}{*}{ UP } & $364, N 6$ & 20 & $2 / 6$ & 12 & 798 & 131 & 1443 \\
\hline & $865, N 23$ & 19 & 216 & 13 & 799 & 132 & 1443 \\
\hline \multirow[t]{2}{*}{ DOWN } & $B 64, N 6$ & 49 & 23 & 7 & 653 & 50 & 1263 \\
\hline & $865, N_{23}$ & 49 & 23 & 8 & 654 & 59 & 1263 \\
\hline
\end{tabular}




\section{DESIGN CALCULATION}

(1) Drawing H-2-690044

(2) Doc. No.

(3) Page 2.8 of 62

(4) Building

NlA

(5) Rev.

(6) Job No

(7) Subject_Core Sampler Truck Nos 3 \& 4 Shielded_Receiver_lifting Frame_Assemhly

(8) Originator FiR LoccereT

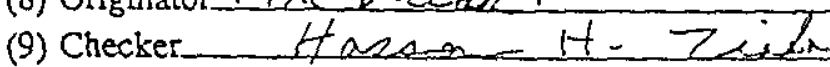

Date $416 / 45$

Date $6-3 \pm-25$

\section{TRANSPORT LOADS_ANACYSIS}

(Ref. Drawings F-2-690043 and 690044 Sh. 1 \& 2)

WELD JOINT FORCES: (Moveable Frame in Down Position)

MEMBERS (3) TO (3) LOWER BRALE FrameLIETIN

IOINT SKETCH: GLOBAL COORDINATES
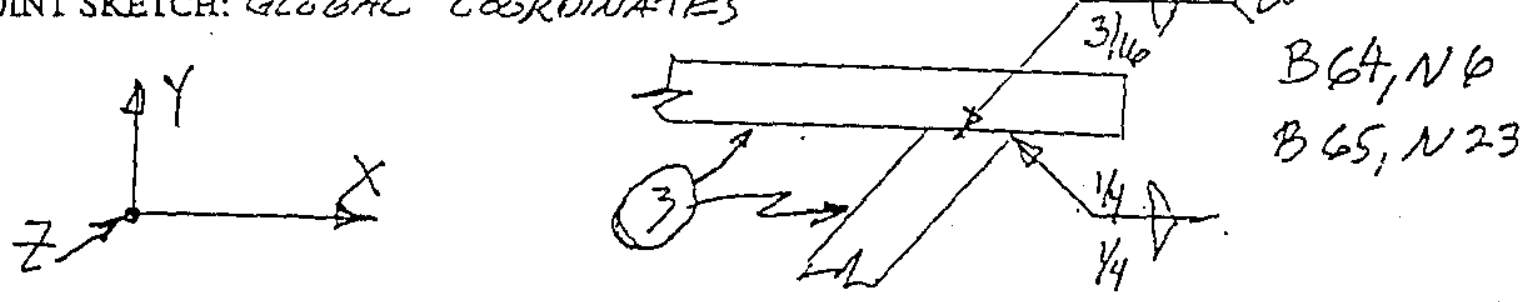

With Mz Restrained at Nodes 85 and 86

\begin{tabular}{|l|l|l|l|l|l|l|l|}
\hline $\begin{array}{l}\text { Longitudinal } \\
\text { Load } \\
\text { Direction }\end{array}$ & $\begin{array}{l}\text { Beam and } \\
\text { Node } \\
\text { Numbers }\end{array}$ & $\begin{array}{l}\text { Fx } \\
\text { lbs }\end{array}$ & $\begin{array}{l}\text { Fy } \\
\text { lbs }\end{array}$ & $\begin{array}{l}\text { Fz } \\
\text { lbs }\end{array}$ & $\begin{array}{l}\text { Mx } \\
\text { in-lbs }\end{array}$ & $\begin{array}{l}\text { My } \\
\text { in-lbs }\end{array}$ & $\begin{array}{l}\text { Mz } \\
\text { in-lbs }\end{array}$ \\
\hline FORWARD & $B 64, N 6$ & 48 & 185 & 71 & 2194 & $51 /$ & 1967 \\
\hline AFT & $365, N 23$ & 15 & 21 & 104 & 1640 & 259 & 804 \\
\hline & $864, N 6$ & 114 & 97 & 136 & 3095 & 886 & 2431 \\
\hline
\end{tabular}

Without Ma Restrained at Nodes 85 and 86

\begin{tabular}{|l|l|l|l|l|l|l|l|}
\hline $\begin{array}{l}\text { Longitudinal } \\
\text { Load } \\
\text { Direction }\end{array}$ & $\begin{array}{l}\text { Beam and } \\
\text { Node } \\
\text { Numbers }\end{array}$ & $\begin{array}{l}\text { Fx } \\
\text { lbs }\end{array}$ & $\begin{array}{l}\text { Fy } \\
\text { lbs }\end{array}$ & $\begin{array}{l}\mathrm{Fz} . \\
\text { lbs }\end{array}$ & $\begin{array}{l}\text { Mx } \\
\text { in-lbs }\end{array}$ & $\begin{array}{l}\text { My } \\
\text { in-lbs }\end{array}$ & $\begin{array}{l}\mathrm{Mz} \\
\text { in-lbs }\end{array}$ \\
\hline FORWARD & $864, N 6$ & 42 & 196 & 74 & 2204 & 393 & 1984 \\
\cline { 2 - 9 } & $865, N 23$ & 10 & 7 & 97 & 1365 & $3 / 5$ & 739 \\
\hline \multirow{2}{*}{ AFT } & $864, N 6$ & 114 & 100 & 137 & 3120 & 876 & 2442 \\
\cline { 2 - 9 } & $866, N 23$ & 70 & 140 & 83 & 1247 & 286 & 966 \\
\hline
\end{tabular}


RPP-6018, Rev. 0

ANALYTICAL CALCULATIONS

Page 29 of 62

SUbject ERLF WESR JOINS STRESSANACYIES, TPUCES $3+4$

Originator FRY VoLSERT

Checker

Hassa H. Zisin

Date $A 1 / 9195$

Date $6-30-95$

MEMIBERS (3) TO (3) LOWER BRALFrame LIFTING

JOLNT SKETCH:
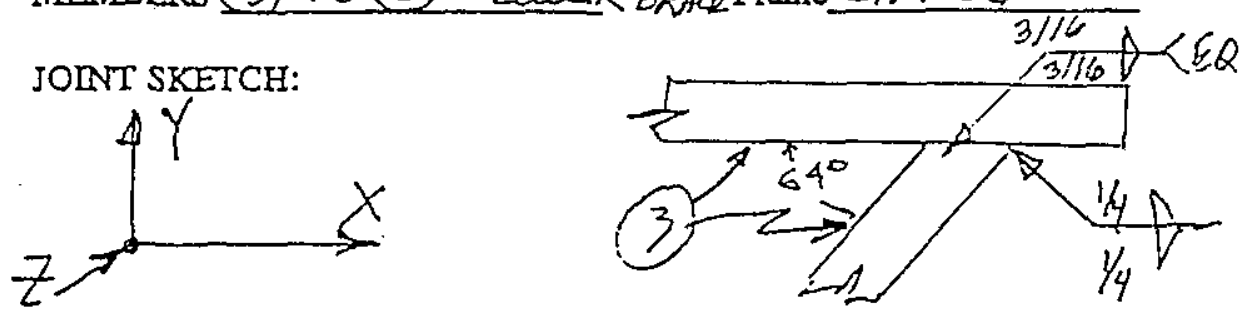

$$
\begin{aligned}
& B 64, N \varphi \\
& B 65, N 23
\end{aligned}
$$

MAXIMUM WELO FORCES

(DEAOWEICHT) $M_{X}=798 / N-\angle B, M_{Z}=1442 \mathrm{~N} \angle B$

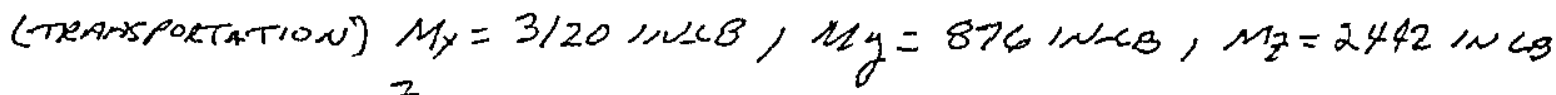

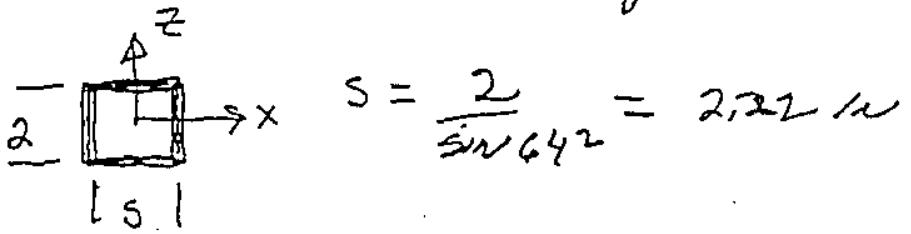

$$
\begin{aligned}
& I_{3}=2 \times 2 \times(1,11)^{2}+2 \times 2.22^{3} / 12=6.75 \mathrm{~N}^{3}, \dot{S}_{3}=6.081 \mathrm{~N}^{2}
\end{aligned}
$$

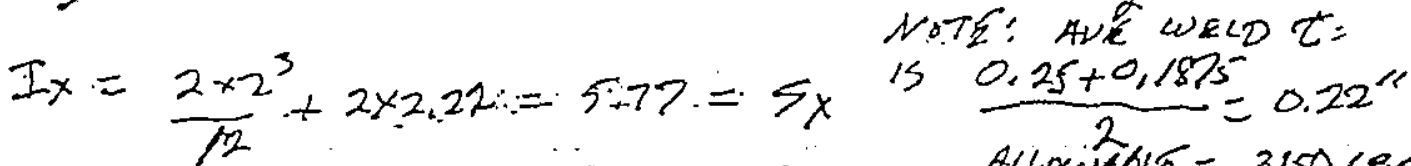

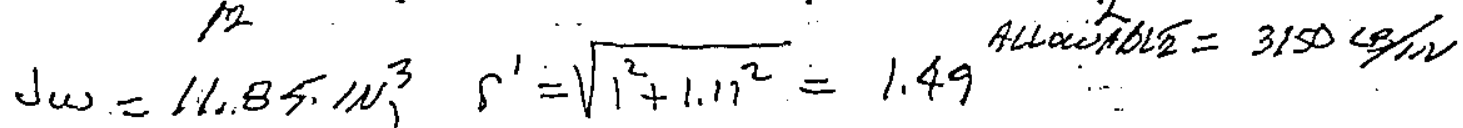

$\therefore$ WELD STRESSES

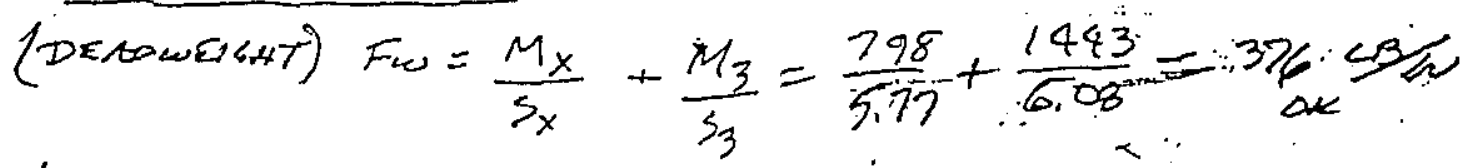

tiraAs PORTATION)

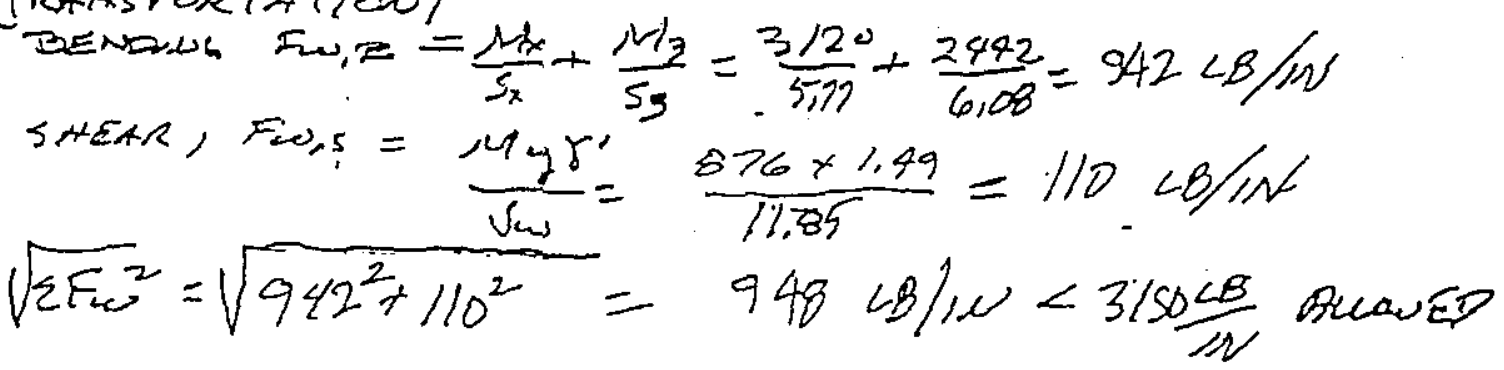

$B-31$

$80-8400-060.1(07 / 93)$

C-80 


\section{DESIGN CALCULATION}

(1) Drawing Et-2-690044

(2) Doc. No.

(3) Page 30 of 62

(4) Building

NIA

(5) Rev

(6) Job No

(7) Subject Core Sampler Truck Nos 3.\& 4 Shielded Receiver I iffing Erame Assembiy

(8) Originator E\&R. Yos-ERT

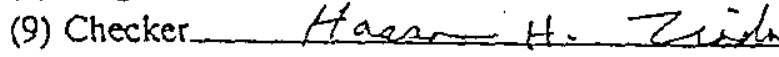

\section{DEAD WEIGAT ANALXSIS}

(Ref. Drawings H-2-690043 and 690044 Sh. 1 \& 2)

WELD JOINT FORCES: GLOBAL CCOROWATES

MEMBBERS (3) TO 3 VERT ERTICE Frame LIFTING

JONT SKETCH:
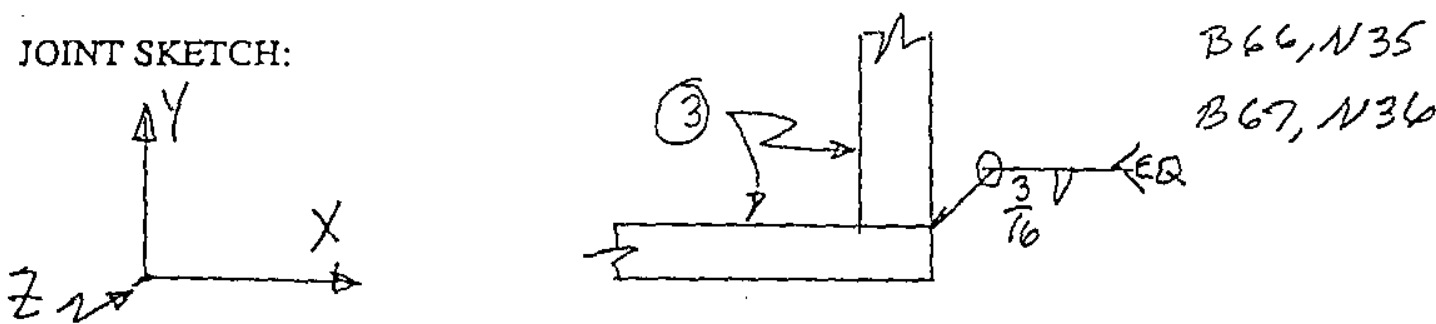

With Mz Restrained at Nodes 85 and 86

\begin{tabular}{|l|l|l|l|l|l|l|l|}
\hline $\begin{array}{l}\text { Moveable } \\
\text { Frame } \\
\text { Position }\end{array}$ & $\begin{array}{l}\text { Beam and } \\
\text { Node } \\
\text { Numbers }\end{array}$ & $\begin{array}{l}\text { Fx } \\
\text { lbs }\end{array}$ & $\begin{array}{l}\text { Fy } \\
\text { lbs }\end{array}$ & $\begin{array}{l}\text { Fz } \\
\text { lbs }\end{array}$ & $\begin{array}{l}\text { Mx } \\
\text { in-lbs }\end{array}$ & $\begin{array}{l}\text { My } \\
\text { in-lbs }\end{array}$ & $\begin{array}{l}\text { inz } \\
\text { in-lbs }\end{array}$ \\
\hline UP & $B 66, N 35$ & 11 & 108 & 23 & 131 & 63 & 206 \\
\cline { 2 - 8 } & $367, N 36$ & 11 & 108 & 23 & 132 & 64 & 205 \\
\hline \multirow{2}{*}{ DOWN } & $B 66, N 35$ & 2 & 47 & 18 & 85 & 25 & 29 \\
\cline { 2 - 8 } & $B 67, N 36$ & 2 & 47 & 18 & 86 & 26 & 29 \\
\hline
\end{tabular}

Without Mz Restrained at Nodes 85 and 86

\begin{tabular}{|c|c|c|c|c|c|c|c|}
\hline $\begin{array}{l}\text { Moveable } \\
\text { Frame } \\
\text { Position }\end{array}$ & $\begin{array}{l}\text { Beam and } \\
\text { Node } \\
\text { Numbers }\end{array}$ & $\begin{array}{l}\text { Fx } \\
\text { lbs }\end{array}$ & $\begin{array}{l}\text { Fy } \\
\text { lbs }\end{array}$ & $\begin{array}{l}\mathrm{Fz} \\
\mathrm{Ibs}\end{array}$ & $\begin{array}{l}M x \\
\text { in-lbs }\end{array}$ & $\begin{array}{l}\text { My } \\
\text { in-lbs }\end{array}$ & $\begin{array}{l}\mathrm{Mz} \\
\mathrm{in}-\mathrm{lbs}\end{array}$ \\
\hline \multirow[t]{2}{*}{ UP } & $B 66, N 35$ & 11 & 108 & 24 & 145 & 75 & 205 \\
\hline & B67. VY & 11 & 107 & 24 & 146 & 76 & 204 \\
\hline \multirow[t]{2}{*}{ DOWN } & 1360,435 & 2 & 47 & 18 & 78 & 19 & 30 \\
\hline & $B C 7,136$ & 2 & 48 & 18 & 74 & 20 & 30 \\
\hline
\end{tabular}




\section{DESIGN CALCULATION}

(1) Drawing H-2-690044

(4) Building N/A

(2) Doc. No.

(5) Rey

(3) Page 31 of 62

(7) Subject Core Sampler Tnick Nos $3 \& 4$ Shielded Receiver Lifring Erame Assembly

(8) Originator_F., , LoceserT

(9) Checker. Haenen H. Zsand.

TRANSPORT LOADS ANALYSIS

(Ref. Drawings H-2-690043 and 690044 Sh. 1 \& 2)

WEID JOINT FORCES: (Moreable Frame in Down Position)

MEMIBERS (3) TO VERT BRACE

GLOBA COOROINATES

JOINT SKETCH:
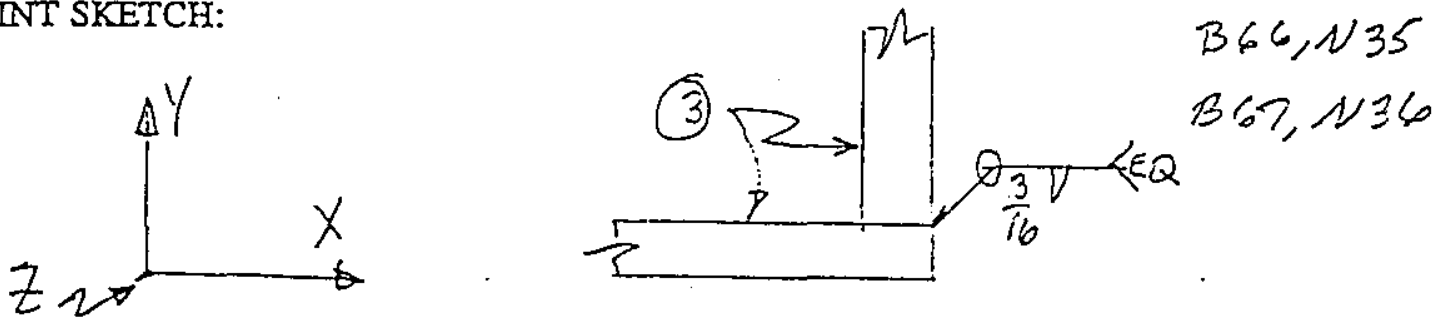

With Mz Restrained at Nodes 85 and 86

\begin{tabular}{|c|c|c|c|c|c|c|c|}
\hline $\begin{array}{l}\text { Longitudinal } \\
\text { Load } \\
\text { Direction }\end{array}$ & $\begin{array}{l}\text { Beam and } \\
\text { Node } \\
\text { Numbers } \\
\end{array}$ & Fx & $\begin{array}{l}\text { Fy } \\
\text { Ibs }\end{array}$ & $\begin{array}{l}\text { Fz } \\
\text { 1bs }\end{array}$ & $\begin{array}{l}\text { Mx } \\
\text { in-lbs }\end{array}$ & $\begin{array}{l}\text { My } \\
\text { in-lbs }\end{array}$ & $\begin{array}{l}\mathrm{Mz} \\
\text { in-lbs }\end{array}$ \\
\hline \multirow{2}{*}{$\begin{array}{c}\text { FORWARD } \\
?\end{array}$} & $B 66, N 35$ & 10 & $22 B$ & 126 & 2237 & 52 & 89 \\
\hline & $367, N 3 d$ & 14 & 150 & 115 & 2563 & 250 & 60 \\
\hline \multirow[t]{2}{*}{ AFT } & 066,135 & 10 & 283 & 149 & 2809 & 47 & 156 \\
\hline & $B 67, N 36$ & 15 & 119 & 118 & 2599 & 162 & 7 \\
\hline
\end{tabular}

Without Mz Restrained at Nodes 85 and 86

\begin{tabular}{|c|c|c|c|c|c|c|c|}
\hline $\begin{array}{l}\text { Longitudinal } \\
\text { Load } \\
\text { Direction } \\
\end{array}$ & $\begin{array}{l}\text { Beam and } \\
\text { Node } \\
\text { Numbers }\end{array}$ & $\begin{array}{l}\text { Fx } \\
\text { Ibs }\end{array}$ & $\begin{array}{l}\text { Fy } \\
\text { Ibs }\end{array}$ & $\begin{array}{l}\mathrm{Fz} \\
\mathrm{lbs}\end{array}$ & $\begin{array}{l}\mathrm{Mx} \\
\text { in-lbs }\end{array}$ & $\begin{array}{l}\text { My } \\
\text { in-lbs }\end{array}$ & $\begin{array}{l}\mathrm{Mz} \\
\text { in-lbs }\end{array}$ \\
\hline \multirow[t]{2}{*}{ FORWARD } & 366,135 & 9 & 220 & 128 & 2252 & 36 & 68 \\
\hline & $867, N \leq 6$ & 13 & 148 & 104 & 2431 & $2 / 2$ & 49 \\
\hline \multirow[t]{2}{*}{ AFT } & $266, N 35$ & 9 & 286 & 142 & 2832 & 63 & 151 \\
\hline & $867, N 36$ & 15 & 122 & 119 & 2621 & 178 & 2 \\
\hline
\end{tabular}


ANALYTICAL CALCULATIONS
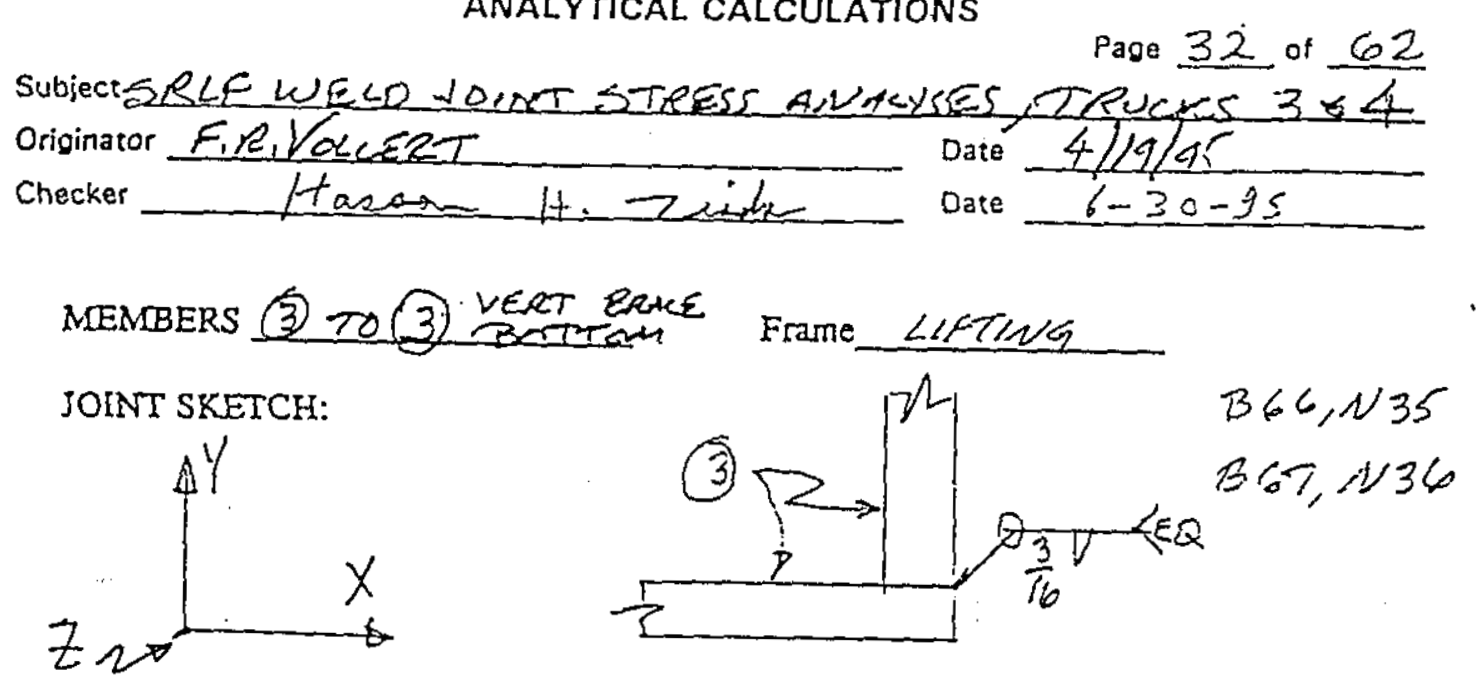

MAXMUM WEUO FORCES

(DEAOWE/GAT) $M_{X}=145 \mathrm{WLA}, M_{Z}=205 \mathrm{~N} \angle B$

(TRANSPOCTATIDN) $M X=2832 \mathrm{~N} \mathrm{LB}$

FUR ENO wECD, $z_{x-2}$

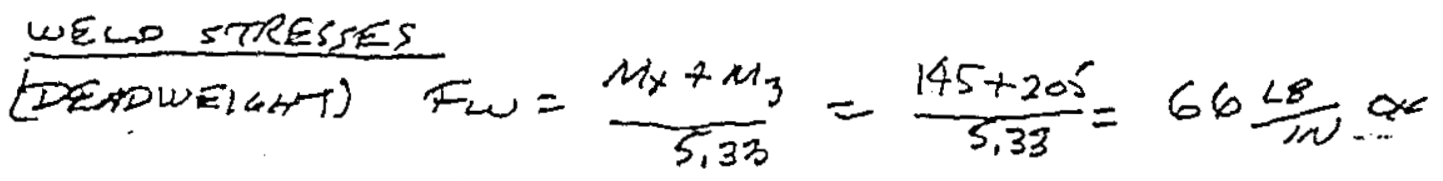

(TRANSPORTATIOM) $F_{U}=\frac{M x}{5,33}=\frac{2832}{5,33}=531 \mathrm{cB} / \mathrm{s}$ or

$B-34$ 


\section{DESIGN CALCULATION}

(1) Drawing $8-2.6900044$

(2) Doc. No.

(3) Page 33 of 62

(4) Building

NiLA

(5) Rev

(0) Job No.

(7) Subject Core Sampler Truck Nos 3 \&
(8) Originator_E. Les LERT

RT

(9) Checker

Hresan

H. Zrids

Enome Assembly

Date $4 / 4 / 95$

Date $6-3 c-95$

\section{DEAD WEIGHT.ANAIXSIS}

(Ref. Drawings H-2-690043 and 690044 Sh. 1 \& 2)

WELD JOINT FORCES:

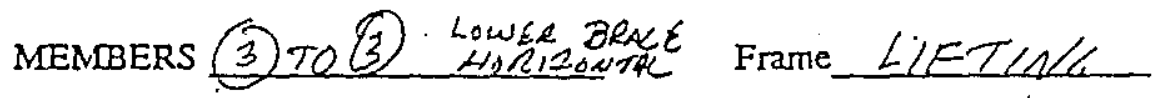

JOINT SKETCH:
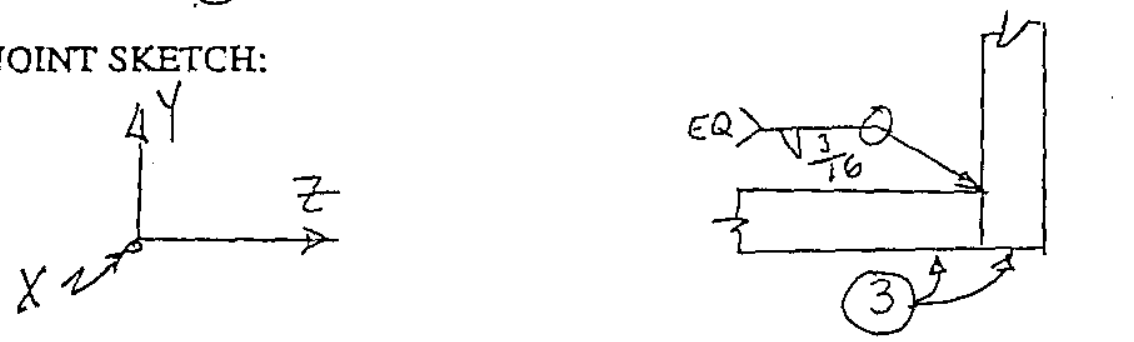

$B 48, N 35 \div N 36$

With Mz Restrained at Nodes 85 and 86

\begin{tabular}{|l|l|l|l|l|l|l|l|}
\hline $\begin{array}{l}\text { Moveable } \\
\text { Frame } \\
\text { Position }\end{array}$ & $\begin{array}{l}\text { Beam and } \\
\text { Node } \\
\text { Numbers }\end{array}$ & $\begin{array}{l}\text { Fx } \\
\text { lbs }\end{array}$ & $\begin{array}{l}\text { Fy } \\
\text { Ibs }\end{array}$ & $\begin{array}{l}\text { Fz } \\
\text { lbs }\end{array}$ & $\begin{array}{l}\text { Mx } \\
\text { in-lbs }\end{array}$ & $\begin{array}{l}\text { My } \\
\text { in-lbs }\end{array}$ & $\begin{array}{l}\text { Mz } \\
\text { in-lbs }\end{array}$ \\
\hline UP & $B 48, N 35$ & 0 & 9 & 47 & 311 & 196 & 1 \\
\hline DOWN & $N 36$ & 0 & 9 & 47 & 312 & 192 & 1 \\
\hline & $N 35$ & 0 & 9 & 14 & 283 & 66 & 0 \\
\hline
\end{tabular}

Without $\mathrm{Mz}$ Restrained at Nodes 85 and 86

\begin{tabular}{|l|l|l|l|l|l|l|l|}
\hline $\begin{array}{l}\text { Moveable } \\
\text { Frame } \\
\text { Position }\end{array}$ & $\begin{array}{l}\text { Beam and } \\
\text { Node } \\
\text { Numbers }\end{array}$ & $\begin{array}{l}\text { Fx } \\
\text { lbs }\end{array}$ & $\begin{array}{l}\text { Fy } \\
\text { lbs }\end{array}$ & $\begin{array}{l}\text { Fz } \\
\text { lbs }\end{array}$ & $\begin{array}{l}\text { Mx } \\
\text { in-lbs }\end{array}$ & $\begin{array}{l}\text { My } \\
\text { in-lbs }\end{array}$ & $\begin{array}{l}\text { Mz } \\
\text { in-lbs }\end{array}$ \\
\hline UP & B48,N35 & 0 & 9 & 57 & 309 & 241 & 1 \\
\hline N36 & 0 & 9 & 57 & 310 & 237 & 1 \\
\hline DOWN & N35 & 0 & 9 & 9 & 284 & 44 & 0 \\
\cline { 2 - 9 } & N34 & 0 & 9 & 9 & 285 & 41 & 0 \\
\hline
\end{tabular}




\section{DESIGN CALCULATION}

(1) Drawing H $1-2-600044$

(4) Building

N/A

(2) Doc. No.

(3) Page 34 of 62

(7) Subject Core Sampler Truck Nos $3 \& 4$ Shielded Beceiver Lifting Frame Assembiy

(8) Originator File KoceERT

(9) Checker Hasen It 2 ian

Date $4 / 2 / 95$

Date $6-30-95$

\section{TRANSPORT LOADS ANATYSTS}

(Ref. Drawings H-2-690043 and 690044 Sh. 1 \& 2)

WELD JOINT FORCES: (Moveable Frame in Down Position)

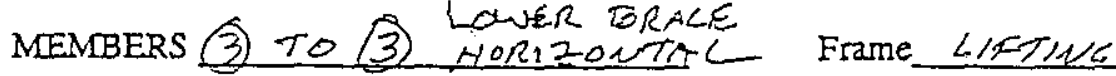

GLOB AL COORONWATES
JOINT SKETCH:
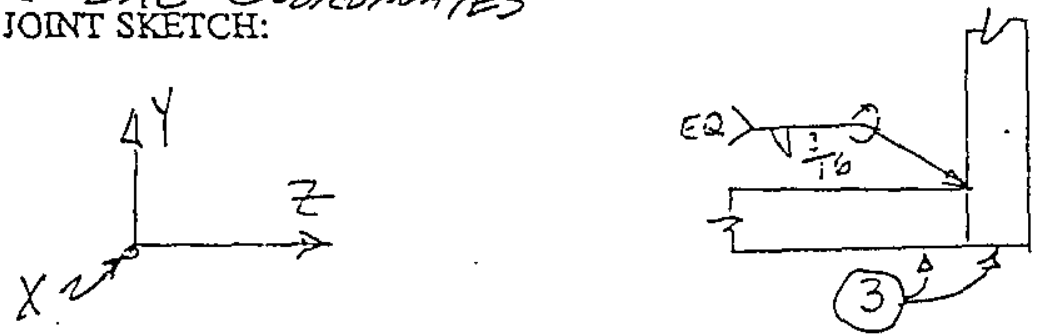

$B 48, N 35 \div N 36$

With Mz Restrained at Nodes 85 and 86

\begin{tabular}{|l|l|l|l|l|l|l|l|}
\hline $\begin{array}{l}\text { Longitudinal } \\
\text { Load } \\
\text { Direction }\end{array}$ & $\begin{array}{l}\text { Beam and } \\
\text { Node } \\
\text { Numbers }\end{array}$ & $\begin{array}{l}\text { Fx } \\
\text { lbs }\end{array}$ & $\begin{array}{l}\text { Fy } \\
\text { lbs }\end{array}$ & $\begin{array}{l}\text { Fz } \\
\text { lbs }\end{array}$ & $\begin{array}{l}\text { Mx } \\
\text { in-lbs }\end{array}$ & $\begin{array}{l}\text { My } \\
\text { in-lbs }\end{array}$ & $\begin{array}{l}\text { Mz } \\
\text { in-lbs }\end{array}$ \\
\hline $\begin{array}{r}\text { FORWARD } \\
\therefore 48, N 35\end{array}$ & 55 & 174 & 93 & 3727 & 1858 & 71 \\
\hline \multirow{2}{*}{$\begin{array}{l}\text { AFT } \\
\therefore . . .\end{array}$} & 64 & 152 & 86 & 3107 & 642 & 71 \\
\cline { 2 - 8 } & $\times 36$ & 59 & 163 & 114 & 3450 & 897 & 53 \\
\hline
\end{tabular}

Without Mz Restrained at Nodes 85 and 86

\begin{tabular}{|c|c|c|c|c|c|c|c|}
\hline $\begin{array}{l}\text { Longitudinal } \\
\text { Load } \\
\text { Direction }\end{array}$ & $\begin{array}{l}\text { Beam and } \\
\text { Node } \\
\text { Numbers }\end{array}$ & $\begin{array}{l}\text { Fx } \\
\text { lbs }\end{array}$ & $\begin{array}{l}\text { Fy } \\
\text { lbs }\end{array}$ & $\begin{array}{l}\mathrm{Fz} \\
\text { ibs }\end{array}$ & $\begin{array}{l}\text { Mx } \\
\text { in-libs }\end{array}$ & $\begin{array}{l}\text { My } \\
\text { in-los }\end{array}$ & $\begin{array}{l}\mathrm{Mz} \\
\text { in-lbs }\end{array}$ \\
\hline \multirow[t]{2}{*}{ FORWARD } & $B 48, N 35$ & 58 & 166 & 40 & 3595 & 1674 & 108 \\
\hline & $N 36$ & 66 & 144 & 33 & 2931 & 921 & 108 \\
\hline \multirow[t]{2}{*}{ AFT } & 135 & 70 & 186 & 121 & $38 \%$ & $18 \infty$ & 75 \\
\hline & $1 / 36$ & 62 & 164 & 114 & 3465 & 961 & 75 \\
\hline
\end{tabular}


RPP-6018, Rev. 0

ANALYTICAL CALCULATIONS

Page 35 of 62

Subject SRLF WELD JOINT STRESS RNALVISE, TRUCKS $3+4$

originator ER DousRT

Checker Hasorac H. Zide

Date $4 / 19 / 95$

Date $6-30-9 s$

MEMBERS (3) To (3) LowEL Bene

JOINT SKETCH:
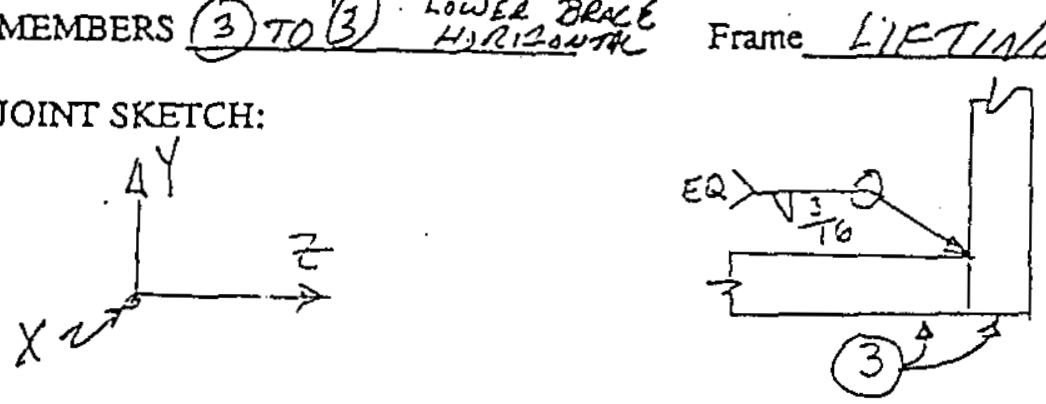

$348, N 35 \div N 36$

MAXIMUM WELP TORGES

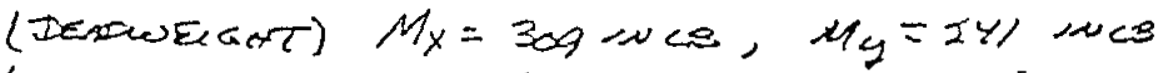

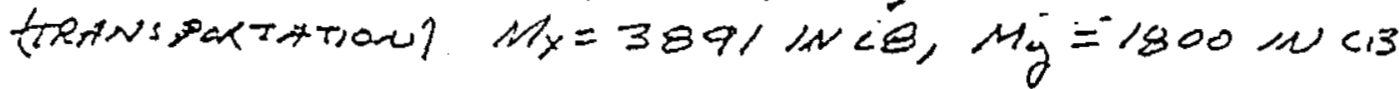

END WECD $2 \times 2$

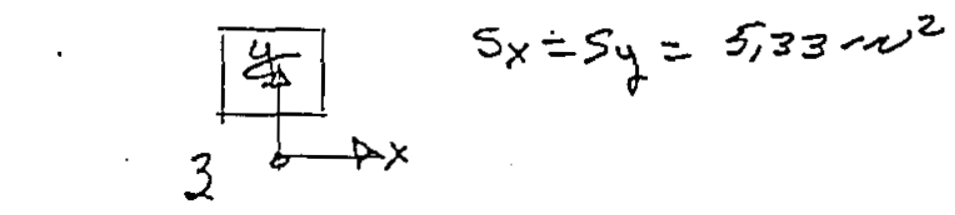

WEL STRESSES

(DEADWFect T) $F_{W}=\frac{M_{x}+M_{y}}{5.33}=\frac{3.04+241}{5.33}=103 \frac{48}{N}$ oK

(TRANSPORTATIOW) $\hbar_{E}=\frac{M_{3+M Y}}{5.33}=\frac{.3891+1800}{.5 .33}=\frac{1008 \mathrm{CB}}{\mathrm{N}}$

$B-37$

8D. $8400.060 .1(07 / 93)$

C-86 


\section{DESIGN CALCULATION}

(1) Drawing $\mathrm{H}=2-690044$

(4) Building_ N/LA

(2) Doc. No.

(3) Page_36. of 62

(7) Subject Core Sampler Truck Nos 3\&4 Shielded Receiver Lifting Ename_Assembly

(8) Originator_ F. R. Lesed _ _ Date $4 / 5 / 95$

(9) Checker Hasen H. This

Date $6-3 a-95$

\section{DEAD WEIGET ANALYSIS}

(Ref. Drawings H-2-690043 and 690044 Sh. 1 \& 2)

WELD JONT FORCES: GLORAL COORDINATES

MEMBERS (3) AND (3) TOS (5)

JOINT SKETCH:<smiles>[Y]C([3H])([3H])[V]</smiles>

Frame LIFTING

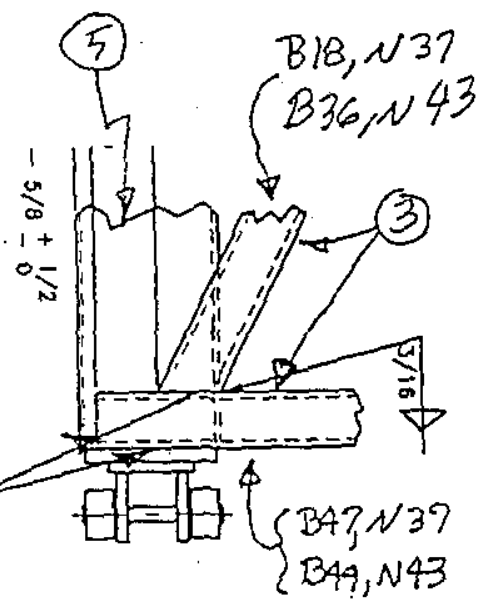

With Mz Restrained at Nodes 85 and 86

\begin{tabular}{|c|c|c|c|c|c|c|c|}
\hline $\begin{array}{l}\text { Moveable } \\
\text { Frame. } \\
\text { Position }\end{array}$ & $\begin{array}{l}\text { Beam and } \\
\text { Node } \\
\text { Numbers }\end{array}$ & lbs & lbs & lbs & in-Ibs & in-lbs & $\begin{array}{l}\mathrm{Mz} \\
\mathrm{in}-\mathrm{lbs}\end{array}$ \\
\hline \multirow{4}{*}{ UP } & $B A Z, N 3 Z$ & 12 & 92 & 24 & 180 & 65 & 110! \\
\hline & $049, N 43$ & 11 & 92 & 24 & 180 & 67 & 1029 \\
\hline & $B 18, N 37$ & $B$ & 73 & 13 & 423 & 24 & 585 \\
\hline & $336, N 43$ & 7 & 72 & 12 & 422 & 24 & 524 \\
\hline \multirow{4}{*}{ DOWN } & $84,1 / 32$ & 2 & 32 & 4 & 198 & 148 & 446 \\
\hline & $\beta 49, \Omega \times 3$ & 3 & 32 & 4 & 198 & 147 & 447 \\
\hline & 318,137 & 47 & 58 & 10 & $\$ 22$ & 47 & 327 \\
\hline & $B 36, N 43$ & 42 & 58 & 10 & 401 & 44 & 322 \\
\hline
\end{tabular}

Without $\mathrm{Mz}$ Restrained at Nodes 85 and 86

\begin{tabular}{|c|c|c|c|c|c|c|c|}
\hline $\begin{array}{l}\text { Moveable } \\
\text { Frame } \\
\text { Position }\end{array}$ & $\begin{array}{l}\text { Beam and } \\
\text { Node } \\
\text { Numbers }\end{array}$ & los & Ibs & los. & $\begin{array}{l}M x \\
\text { in-lbs }\end{array}$ & in-los & in-lbs \\
\hline \multirow{3}{*}{ UP } & $1347, \times 37$ & II & c2 & 33 & 164 & 134 & 1096 \\
\hline & 1349,043 & 11 & 92 & 33 & 164 & 136 & 1094 \\
\hline & $\frac{318,1,37}{832}$ & 8 & 75 & $\frac{12}{12}$ & 407 & -12 & $\frac{583}{582}$ \\
\hline \multirow{4}{*}{ DOWN } & $349, \& 32$ & 2 & 32 & 9 & 208 & 183 & 449 \\
\hline & 249,243 & 2 & 32 & Q & 206 & 182 & 449 \\
\hline & $B / B, \alpha 32$ & 47 & 59 & 11 & 420 & 50 & 323 \\
\hline & $B 3, x, x 43$ & 47 & 59 & 11 & 420 & 50 & 328 \\
\hline
\end{tabular}




\section{DESIGN CALCULATION}
(1) Drawing H-2:690044
(2) Doc. No.
(3) Page 37 of 62
(4) Building
NiA
(5) Rev.
(6) Job No
(7) Subject Core Sampler Truck Nos 3 \& 4 Shielded Beceiver I iffing Erame, Assembiy
(8) Originator E, $R$, $/$ oce $E R T$
(9) Checker Hazaen H. Puidh
Date $1 / 5 / 9,5$
Date $6-30-25$

\section{TRANSPORT IOADS ANALYSIS}

(Ref. Drawings H-2-690043 and 690044 Sh. 1 \& 2)

WELD JOINT FORCES: (Moveable Frame in Down Position)

MEMBERS 周 ANDQ人TCS)

JOINT SKETCH: GLOBAL COORDJNATES

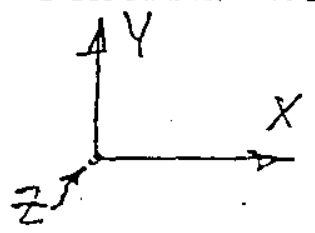

Frame LIFTING

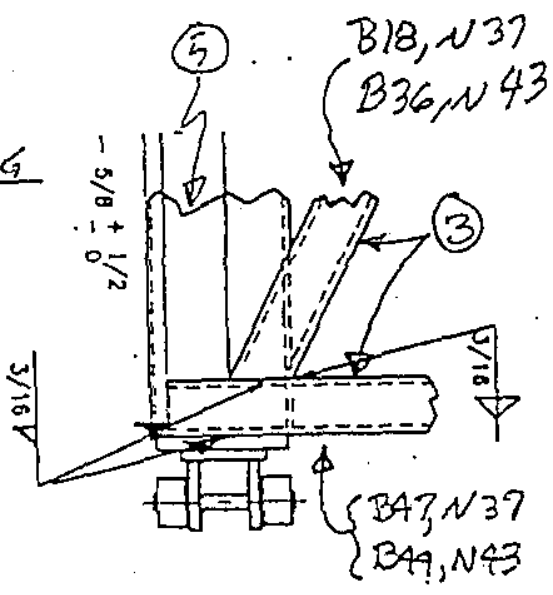

With Mz Restrained at Nodes 85 and 86

\begin{tabular}{|c|c|c|c|c|c|c|c|}
\hline $\begin{array}{l}\text { Longitudinal } \\
\text { Load } \\
\text { Direction }\end{array}$ & $\begin{array}{l}\text { Beam and } \\
\text { Node } \\
\text { Numbers }\end{array}$ & Fx & Fy & $\begin{array}{l}F z \\
\text { lbs }\end{array}$ & $\begin{array}{l}\text { Mx } \\
\text { in-Ibs }\end{array}$ & $\begin{array}{l}\text { My } \\
\text { in-llbs }\end{array}$ & $\mathrm{Mz}$ \\
\hline \multirow{3}{*}{ FORWARD } & & 43 & 46 & 222 & 1490 & 1110 & 525 \\
\hline & & $\frac{52}{44}$ & $\frac{6}{82}$ & $\frac{32}{43}$ & $\frac{544}{1131}$ & $\frac{24}{16}$ & $\frac{101}{225}$ \\
\hline & & 44 & 13 & & 514 & & 351 \\
\hline $\mathrm{AFI}$ & & $\frac{60}{41}$ & $\frac{90}{37}$ & $\frac{265}{6}$ & $\frac{1067}{85}$ & $\frac{1920}{677}$ & $\begin{array}{r}1020 \\
612\end{array}$ \\
\hline & $\frac{318,0,32}{836, A) 43}$ & $-\frac{128}{70}$ & $\frac{224}{59}$ & $\frac{7}{23}$ & $\frac{760}{59}$ & $\frac{-128}{2 \infty}$ & $\frac{595}{586}$ \\
\hline
\end{tabular}

Without Mz Restrained at Nodes 85 and 86

\begin{tabular}{|c|c|c|c|c|c|c|c|}
\hline $\begin{array}{l}\text { Longitudinal } \\
\text { Load } \\
\text { Direction }\end{array}$ & $\begin{array}{l}\text { Beam and } \\
\text { Node } \\
\text { Numbers }\end{array}$ & $\mathrm{lbs}$ & $\begin{array}{l}\text { Fy } \\
\text { lbs }\end{array}$ & lbs & $\begin{array}{l}\mathrm{Mx} \\
\text { in-lbs }\end{array}$ & $\mathrm{inn}_{n} \mathrm{lbs}$ & $\begin{array}{l}\mathrm{Mz} \\
\text { in-lbs }\end{array}$ \\
\hline \multirow[t]{2}{*}{ FORWARD } & $\frac{347,1237}{349,133}$ & $\frac{47}{55}$ & 47 & $\frac{170}{73}$ & $\frac{1343}{500}$ & $-\frac{677}{373}$ & $5 / 2$ \\
\hline & $<\langle a, d<37$ & 35 & 65 & 47 & 1019 & $\frac{460}{26}$ & 220 \\
\hline \multirow{3}{*}{ AFT } & 34,1132 & 63 & 92 & 266 & 1060 & $-\angle 889$ & 10.86 \\
\hline & $\frac{189,443}{B 18, N \geq 2}$ & $\frac{44}{136}$ & $\frac{35}{226}$ & $-\frac{7}{7}$ & $\frac{844}{171}$ & $-\frac{702}{1346}$ & $\frac{600}{594}$ \\
\hline & 1336,143 & 70 & 58 & 23 & 43 & 196 & 380 \\
\hline
\end{tabular}


RPP-6018, Rev. 0

ANALYTICAL CALCULATIONS

Page 38 of 62

SUbject SRLE WELO NOAT STRESS ANAWYSES, TRUCKS 3 L

Originator EL $\operatorname{VQLCERT}$

Checker Haonan H. Heida

Date $4 / 18 / 95$

Date $6-30-95$

MEMIBERS (3) AND (3) TO 5 B JOINT SKETCH:

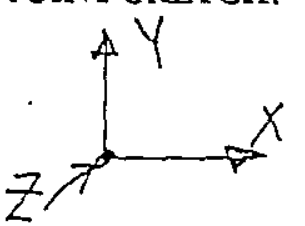

Frame LIFTING

MAXMUU FORESS.

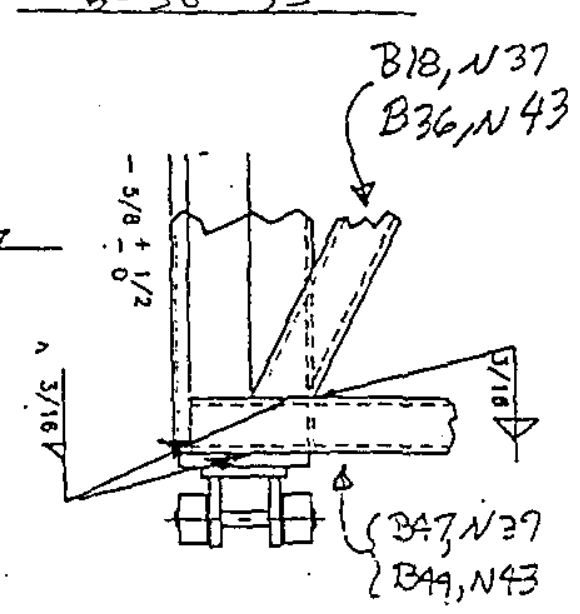

$$
\begin{aligned}
& \text { (DENDWEIGHT) } \\
& B 18 / B 36-M_{X}=423, N \angle B, M_{Z}=585 \mu N-\angle B \\
& B 47 / B 49-M_{y}=180 \mathrm{wLB}, M_{z}=1101 \mathrm{~N} \angle B \\
& \text { (TRAASPORTATION) } \\
& B 18 / B 36-M_{x}=1151 / N \angle B, M_{y}=555 \mathrm{~N} \angle B, M_{z}=225 \mathrm{NL} \angle B \\
& B 47 / 349-M_{x}=1490 \mathrm{~N} \angle B, M_{y}=1110 \mathrm{~N} \angle B, M_{z}=525 \mathrm{NCB}
\end{aligned}
$$

WELO joInTs

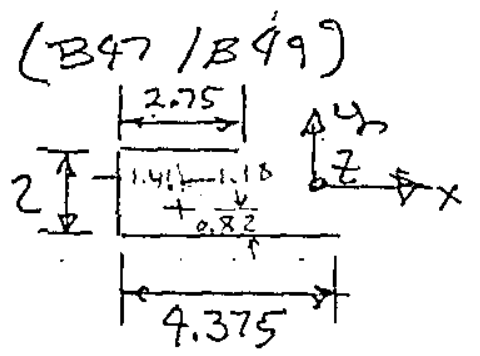

$$
\begin{aligned}
& L \omega=9.125 \\
& \bar{y}=\frac{2 \times 1+2.75 \times 2}{9.125}=0.82 \mathrm{~N} \\
& \bar{x}=\left(\frac{2.75^{2}}{2}+\frac{4.375^{2}}{2}\right) \times \frac{1}{9.125}=1.46 \mathrm{~N} \\
& I_{x}=\frac{2^{3}}{12}+2 \times 0.18^{2}+4.375 \times 0.82^{2}+2.75 \times 1.18^{2}=7.501 \mathrm{~N}^{3} \\
& J_{\omega}=22.82 / \mathrm{No}^{3}, r^{\prime}=\sqrt{0.82^{2}+2,92^{2}}=3,03 \mathrm{~m}
\end{aligned}
$$$$
I_{y}=\frac{2.75^{3}}{12}+\frac{4.375^{3}}{12}+2 \times 1.46^{2}+4.375 \times 0.73^{2}+2.75 \times 0.085^{2}=15.32
$$

$B-40$

$80.6400-060.1(07 / 93)$

C-89 
RPP-6018, Rev. 0

ANALYTICAL CALCULATIONS

Page 39 of 62

Subject SRLF WELD JONN STRESS A NACQSES, TRUET 3 \& \&

Originator FiD VOLERT

Checker Hases $\mathrm{H}=2 \mathrm{Zila}$

Date $4 / 18 / 95$

Date $6-30-45$

(3) AND (3) T0 (5) CONTINUED

$$
\begin{aligned}
& \text { (WRLDS CDNTD } \\
& B 18 / B 36
\end{aligned}
$$

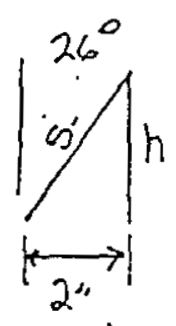

$$
\begin{aligned}
& S=\frac{2}{\cos 64^{\circ}}=4.56 \mathrm{~N} \\
& h=S \sin 64^{\circ}=4.10 \mathrm{~N}
\end{aligned}
$$

$$
\begin{array}{ll}
\mid \underset{2 \mu}{4} & \bar{y}=\frac{h}{2}=2.05 \mathrm{~N} \\
\operatorname{six}_{z \rightarrow x} & \bar{x}=\frac{s \times 1}{s+h}=0.53 \mathrm{~m}
\end{array}
$$

$$
\begin{aligned}
& I_{x}=\frac{2 \times 4.10^{3}}{12}=1,49 \mathrm{~N}^{3} \\
& I_{y}=\frac{2^{3}+h \times 0.53^{2}=1,821 \mathrm{~N}^{3}}{12}
\end{aligned}
$$

(ACSO END WELTD ON 3 ERTES)

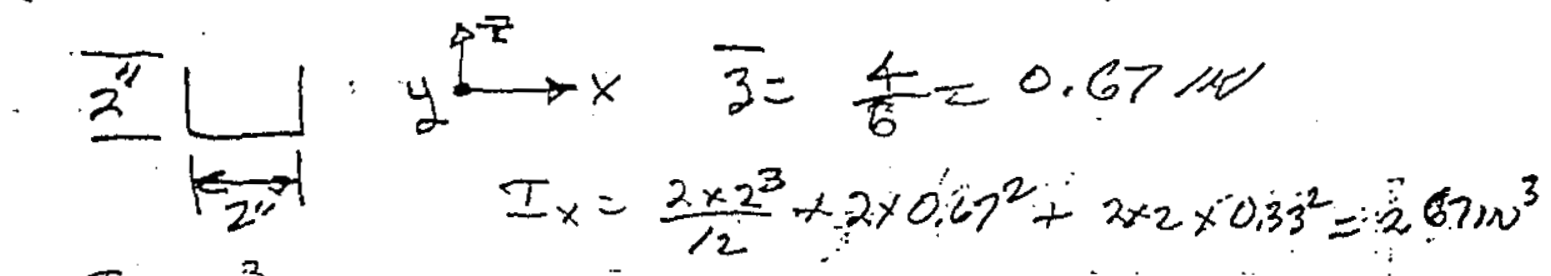

$$
I_{z}=\frac{2^{3}}{12}+2 \times 2 \times 1=4,67 \mathrm{wn}^{3}
$$

(IT IS SAFE TO PAESWUE)

$\Lambda$ WELO RESISTS MX ANOMY

AND

L. END WEW RESISTS $M_{Z}$

$B-41$

$80-8400-060.1$ (07/93)

C-90 
RPP-6018, Rev. 0

ANALYTICAL CALCULATIONS

Page 40 of 62

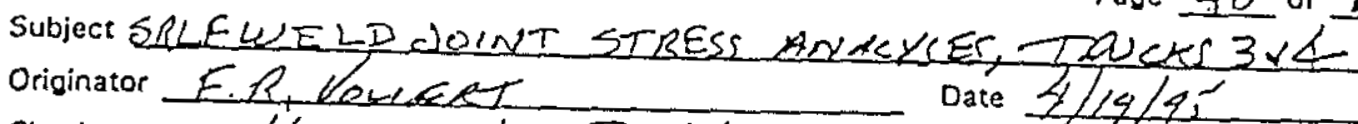

Checker Hasen H. Zuth Date $4 / 14 / 95$ Date $-6-32=45$

(3) AND (3) To (5) Coerinus

WELO STRESSES

उद्व7849

(DERDARIG 4T)

$$
\begin{aligned}
& \text { Benows } F_{\text {w, }}=\frac{M_{\text {Mx }} \times 2.92}{I_{y}}=\frac{180 \times 2.92}{15.3 .2}=34(\mathrm{P} / \mathrm{N}) \\
& \text { SIEAR } F_{w, S}=\frac{M_{E}}{I_{L}} r^{\prime}=\frac{1101 \times 3.03}{22.82}=1.46 \mathrm{LB} / \mathrm{N} \\
& \sqrt{\sum F_{\omega}^{2}}=\sqrt{34^{2} \cdot 146^{2}}=150 \mathrm{LB} / \mathrm{NN} \mathrm{OK}
\end{aligned}
$$

(IRANSPORTATION)

Eeware $F_{w, B}=\frac{M x}{I_{x}} \times 1.16+\frac{\mu y \times 2.42}{I_{y}}=\frac{1490 \times 1.18}{7.5}+\frac{110 \times 2.92}{15.32}$

$$
F_{\omega, B}=446 \mathrm{Lg} / \mathrm{N}
$$

SHEAR FW, DUETO Mj BYPROPARTION

$$
\begin{aligned}
& F_{w, S}=\frac{525}{110,} \times 146^{2}=6.9 \mathrm{CBl} N \\
& \sqrt{\sum F_{\omega}^{2}}=\sqrt{446^{2}+6.9^{2}}=451 \mathrm{LB} / \mathrm{N}<2.775 \mathrm{cB} / \mathrm{N}
\end{aligned}
$$

$B / 8 / B 36$

(DEADLERSTH

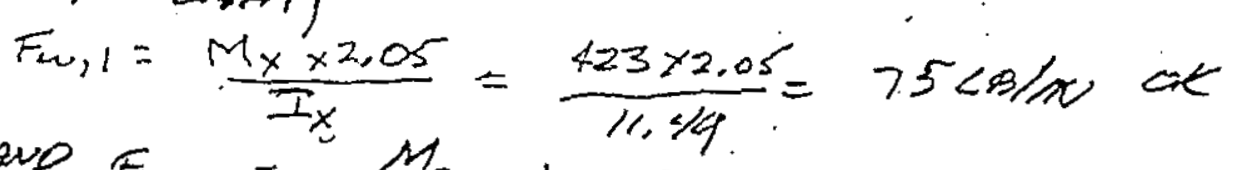
(1)

AND $F_{w 12}=\frac{M_{2}}{T_{3}} \times 1=\frac{585}{4.67}=125 \mathrm{LB} / \mathrm{N}$ or

(Transportation)

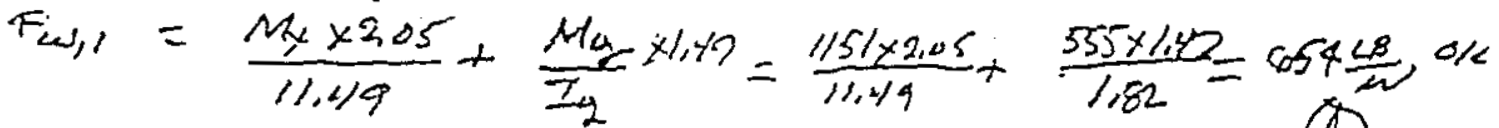

$$
\begin{aligned}
& F_{w, 2}=\frac{\left.M_{x} x\right)}{4,(1)}=\frac{225}{4,67}+5(B)(N \text { OK }
\end{aligned}
$$

C-91 


\section{DESIGN CALCULATTON}

(1) Drawing_H-2-690044

(2) Doc. No.

(4) Building__ _ N $/ \mathrm{A}$

(5) Rev.

(3) Page 41 of 621

(7) Subject Core Sampler Truck Nos 3.\&4 Shielded Receiver Lifting Enme Assembly

(8) Originator E,R Y recERT

(9) Checker Haesion H. $\rightarrow$ Date $4 / 4$ sí $^{-}$ Date $6 \rightarrow 3-95$

\section{DEADWEIGHT ANATYSIS}

(Ref. Drawings H-2-690043 and 690044 Sh. 1 \& 2)

WELD JOINT FORCES: GLOBAL COORDIUATES

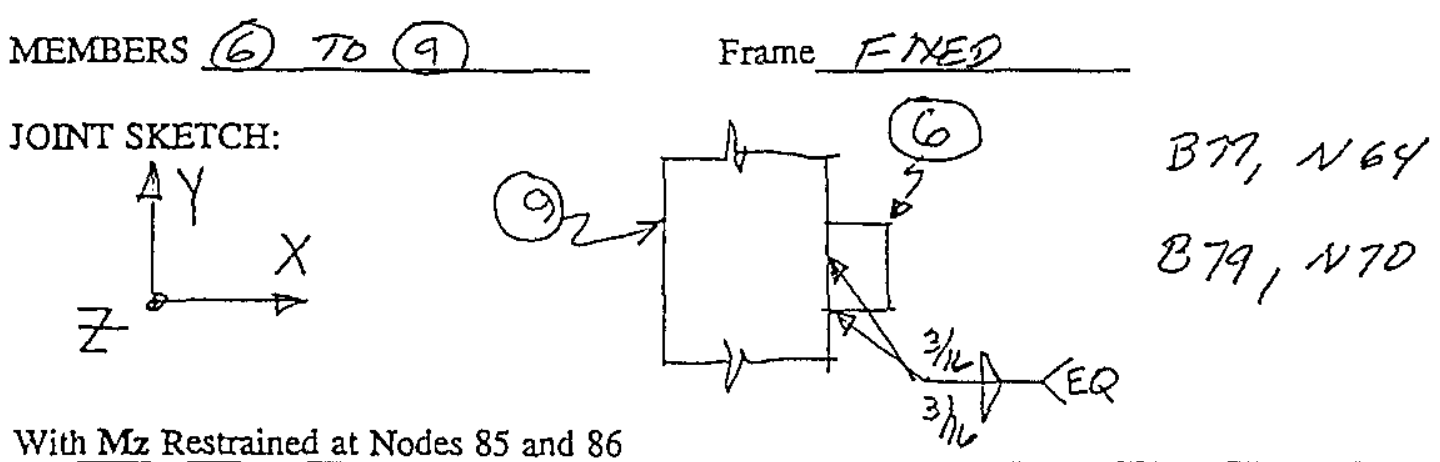

\begin{tabular}{|l|l|l|l|l|l|l|l|}
\hline $\begin{array}{l}\text { Moveable } \\
\text { Frame } \\
\text { Position }\end{array}$ & $\begin{array}{l}\text { Beam and } \\
\text { Node } \\
\text { Numbers }\end{array}$ & $\begin{array}{l}\text { Fx } \\
\text { Ibs }\end{array}$ & $\begin{array}{l}\text { Fy } \\
\text { lbs }\end{array}$ & $\begin{array}{l}\text { Fz } \\
\text { lbs }\end{array}$ & $\begin{array}{l}\text { Mx } \\
\text { in-lbs }\end{array}$ & $\begin{array}{l}\text { My } \\
\text { in-lbs }\end{array}$ & $\begin{array}{l}\text { Mz } \\
\text { in-lbs }\end{array}$ \\
\hline UP & $B 77, N 64$ & 36 & 189 & 88 & 497 & 337 & 171 \\
\cline { 2 - 8 } & $B 79, N 70$ & 35 & 188 & 88 & 497 & 339 & 169 \\
\hline $\begin{array}{l}\text { DOWN } \\
37, N 64\end{array}$ & 40 & 207 & 20 & 697 & 25 & 118 \\
\cline { 2 - 8 } & $379, N 70$ & 40 & 206 & 20 & 696 & 24 & 117 \\
\hline
\end{tabular}

Without $\mathrm{Mz}$ Restrained at Nodes 85 and 86

\begin{tabular}{|c|c|c|c|c|c|c|c|}
\hline $\begin{array}{l}\text { Moveable } \\
\text { Frame } \\
\text { Position } \\
\end{array}$ & $\begin{array}{l}\text { Beam and } \\
\text { Node } \\
\text { Numbers }\end{array}$ & $\begin{array}{l}\text { Fx } \\
\text { los }\end{array}$ & $\begin{array}{l}\text { Fy } \\
\text { lbs }\end{array}$ & $\begin{array}{l}\mathrm{Fz} \\
\mathrm{lbs}\end{array}$ & $\begin{array}{l}\text { Mx } \\
\text { in-lbs }\end{array}$ & $\begin{array}{l}\text { My } \\
\text { in-lbs }\end{array}$ & $\begin{array}{l}\mathrm{Mz} \\
\text { in-lbs }\end{array}$ \\
\hline \multirow[t]{2}{*}{ UP } & $377, N 64$ & 71 & 351 & 87 & 999 & 331 & 68 \\
\hline & $879, N 70$ & 70 & 350 & 87 & 999 & 331 & 67 \\
\hline \multirow[t]{2}{*}{ DOWN } & $B \cap, N \in \mathbb{E}$ & 71 & 352 & 29 & $1 / 35$ & 54 & $3 /$ \\
\hline & $E \times 9, N T C$ & 71 & 351 & 29 & 1135 & 54 & 30 \\
\hline
\end{tabular}

$B-43$ 


\section{DESIGN CAICULATION}

(1) Drawing_H-2-690044

(2) Doc. No.

(3) Page 42 of 62

(4) Building N/A

(5) Rev.

(6) Job No

(7) Subject Core Sampler Truck Nos 3 \& 4 Shielded Receiver Liffing Erame A ssembly

(8) Originator F.R, $V_{U<L E L T}$

(9) Checker Ifosere it Zarta Date $4 / 6 / 95$

Date $6-30-95$

TRANSPORT IOADS ANAIYSIS

(Ref. Drawings H-2-690043 and 690044 Sh. 1 \& 2)

WELD JOINT FORCES: (Moveable Frame in Down Position)

MEMBERS (6) TO (9)

Frame F1XED

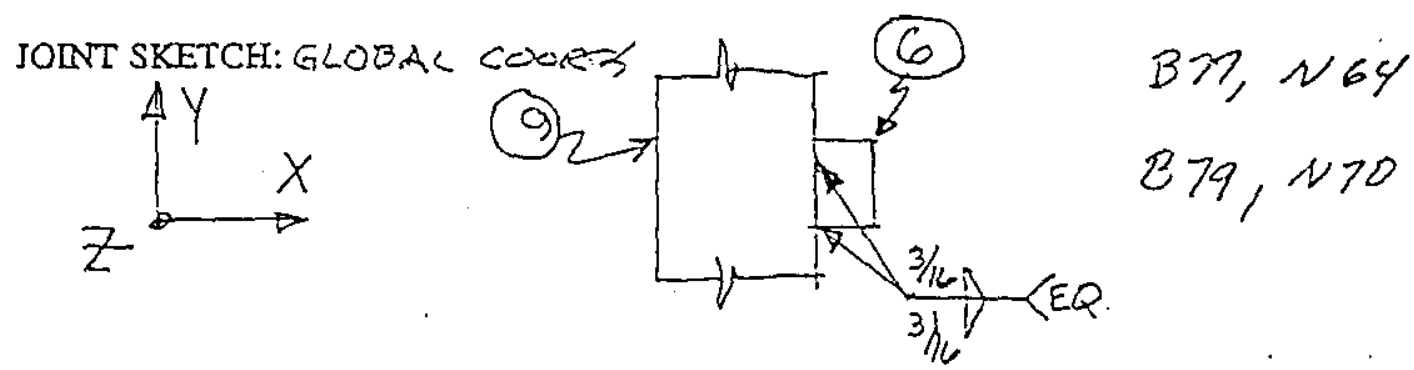

With Mz Restrained at Nodes 85 and 86

\begin{tabular}{|c|c|c|c|c|c|c|c|}
\hline $\begin{array}{l}\text { Longitudinal } \\
\text { Load } \\
\text { Direction }\end{array}$ & $\begin{array}{l}\text { Beam and } \\
\text { Node } \\
\text { Numbers }\end{array}$ & $\begin{array}{l}\text { Fx } \\
\text { lbs }\end{array}$ & $\begin{array}{l}\text { Fy } \\
\text { ibs }\end{array}$ & $\begin{array}{l}\mathrm{Fz} \\
\mathrm{bbs}\end{array}$ & $\begin{array}{l}\text { Mx } \\
\text { in-lbs }\end{array}$ & $\begin{array}{l}\text { My } \\
\text { in-Ibs }\end{array}$ & $\begin{array}{l}\text { Mz } \\
\text { in-lbs }\end{array}$ \\
\hline \multirow[t]{2}{*}{ FORWARD } & $377, N 64$ & 208 & 1438 & $5 / 5$ & 12750 & 2660 & 932 \\
\hline & $B 79, N>0$ & 197 & 622 & 299 & 3725 & 2218 & 71 \\
\hline \multirow{2}{*}{$\begin{array}{l}\text { AFT } \\
\end{array}$} & $13 R, N 64$ & 283 & 1327 & 582 & 970 & 1101 & 636 \\
\hline & $379, N>0$ & 268 & 1665 & 380 & 13680 & 703 & 172 \\
\hline
\end{tabular}

Without Mz Restrained at Nodes 85 and 86

\begin{tabular}{|c|c|c|c|c|c|c|c|}
\hline $\begin{array}{l}\text { Longitudinal } \\
\text { Load } \\
\text { Direction }\end{array}$ & $\begin{array}{l}\text { Beam and } \\
\text { Node } \\
\text { Numbers }\end{array}$ & $\begin{array}{l}\text { Fx } \\
\text { Ibș }\end{array}$ & $\left\{\begin{array}{l}\text { Fy } \\
\text { lbs }\end{array}\right.$ & $\begin{array}{l}\mathrm{Fz} \\
\mathrm{lbs}\end{array}$ & in $16 x$ & $\begin{array}{l}\text { My } \\
\text { in-lbs }\end{array}$ & $\begin{array}{l}\mathrm{Mz} \\
\text { in-lbs }\end{array}$ \\
\hline \multirow{2}{*}{ FORWARD } & $317, N 64$ & 476 & 2663 & 812 & 17530 & 3854 & 1824 \\
\hline & $379, N 70$ & 502 & 2,38 & 599 & 3270 & 3437 & 794 \\
\hline \multirow[t]{2}{*}{ AFT } & $3 n, N 64$ & 670 & 3116 & 681 & 6210 & 1427 & $3 x 44$ \\
\hline & $879, \sqrt{ } 70$ & 628 & 3352 & 485 & 15940 & 1057 & 1254 \\
\hline
\end{tabular}


RPP-6018, Rev. 0

ANALYTICAL CALCULATIONS

Page $43^{\circ}$ of 62

SUbject ZRLE WELD JOINT STRESS ANACUSES, TZUKKS $3+4$ Originator F.R. $\ell_{1} \leq-E q$ Date $4 / 18 / 45$

Checker

Hasen H. Zridx

Date 6-30-9s

MEMBERS (6) To 9

Frame ENEP

JOINT SKETCH:

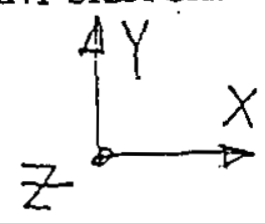

6

(9)
$B \cap, N 64$

$279, N 70$

MATMUMI ForaAs

(DEHOWEIGDT) $M_{X}=1135 / N-L \theta$

(TRANSPORTATIOU)

$$
\begin{aligned}
& M_{x}=17530 \mu \angle \beta, M_{y}=3859 \mathrm{NLB} \\
& M_{z}=1824 \mathrm{NB}, F_{y}=2663 \mathrm{LB}
\end{aligned}
$$

1 WECD voier $\quad I_{y}=\frac{2 \times 26^{3}}{12}+2 \times 3(1.25)^{2}=11.981 \mathrm{~N}^{3}$

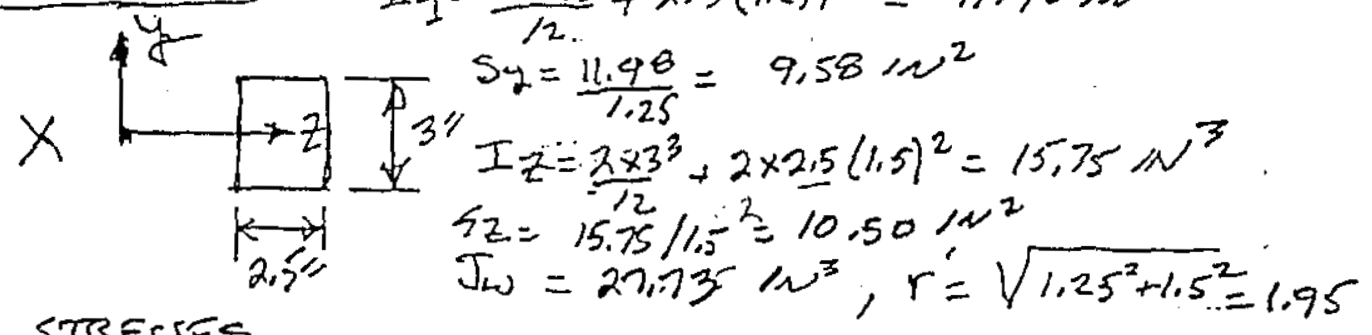

WELD STRESSES

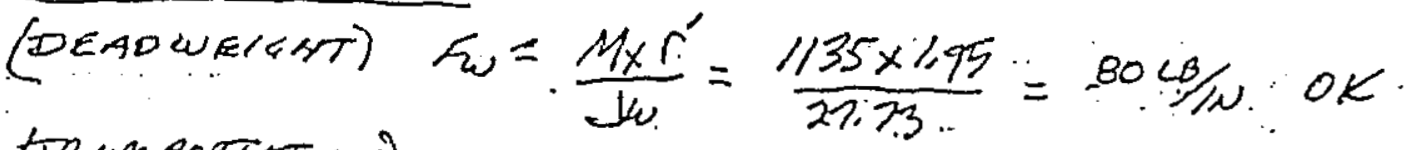

triansportitioni)

SHEAR, $f_{W, S}=\frac{F_{y}}{L_{W}}=\frac{2663}{11}=242: \angle B / \mathrm{LN}$

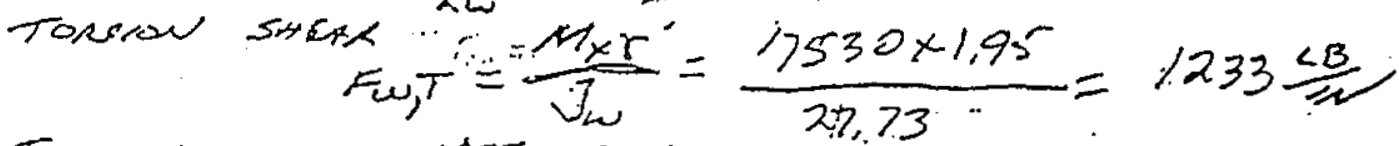

$F_{\omega, T+F, 5}=1475 \mathrm{LBM}$

BENDING $F_{w, B}=\frac{M j}{S_{y}}+\frac{M z}{\xi_{z}}=\frac{3859}{9.58}+\frac{1824}{1050}=57728 \%$

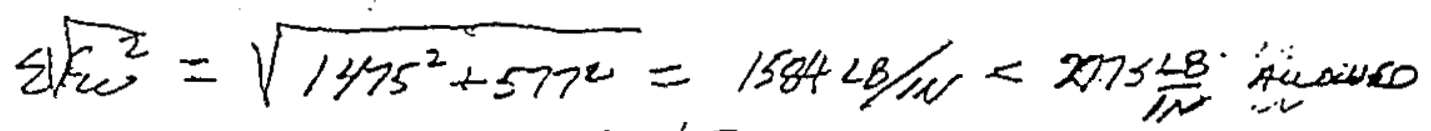

B- 45

$80-8400-050.1607 / 931$

C-94 


\section{DESIGY CALCULATION}
(1) Drawing $\mathrm{H}-2-690044$
(2) Doc. No.
(3) Page 44 of 62
(4) Building
$N \angle A$
(5) Rev
(6) Job No
(T) Subject Core Sampler Truck Nos 3 \& 4 Shielded Rereiver I ifting Enme Assembly

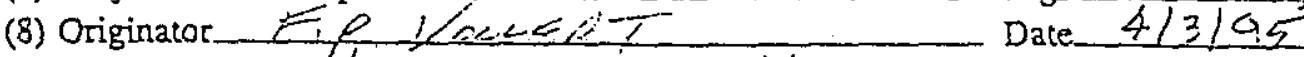
(9) Checker.
Has anes
Date $6-32-35$

DEAD WEIGHT ANALYSIS GLOBAL COOROINATES

(Ref. Drawings H-2-690043 and 690044 Sh. 1 \& 2)

WECD JOINT FORCES: \ulcorner

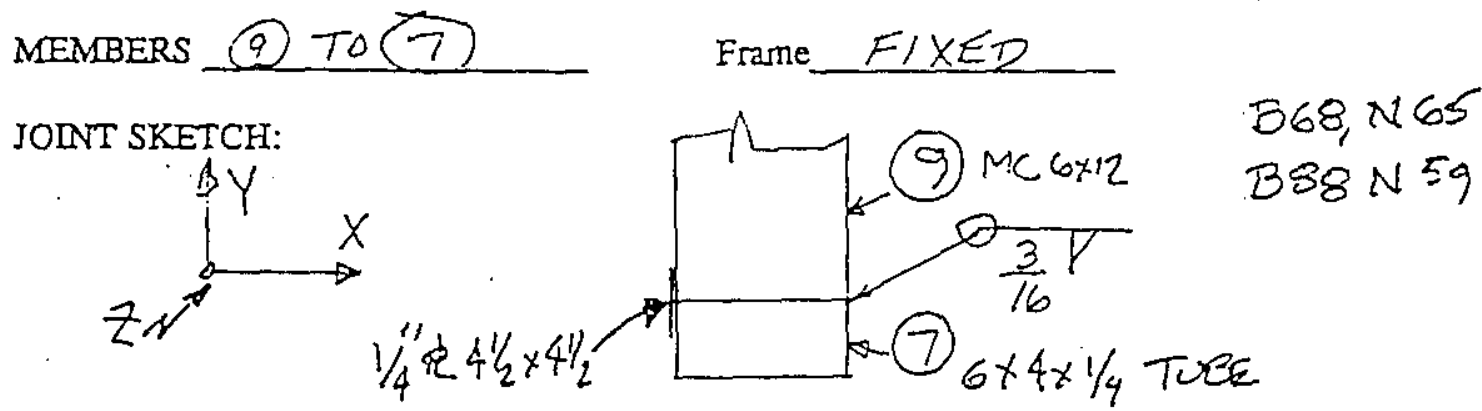

With Mz Restrained at Nodes 85 and 86

\begin{tabular}{|c|c|c|c|c|c|c|c|}
\hline $\begin{array}{l}\text { Moveable } \\
\text { Frame } \\
\text { Position }\end{array}$ & $\begin{array}{l}\text { Beam and } \\
\text { Node } \\
\text { Numbers }\end{array}$ & $\begin{array}{l}\text { Fx } \\
\text { Ibs }\end{array}$ & $\begin{array}{l}\text { Fy } \\
\text { lbs }\end{array}$ & $\begin{array}{l}\mathrm{Fz} \\
\mathrm{Ibs}\end{array}$ & $\begin{array}{l}M x \\
\text { in-lbs }\end{array}$ & $\begin{array}{l}\text { My } \\
\text { in-lbs }\end{array}$ & $\begin{array}{l}\mathrm{Mz} \\
\text { in-lbs }\end{array}$ \\
\hline \multirow{2}{*}{ UP } & $B 68, N 65$ & 35 & 121 & 12 & 6 & 13 & 2346 \\
\hline & $B 88, N 59$ & 36 & 122 & 12 & 4 & 13 & 2353 \\
\hline \multirow{2}{*}{$\begin{array}{l}\text { DOWN } \\
\because \because \because \because\end{array}$} & $368, N 65$ & 40 & 140 & 90 & 348 & 57 & $2 / 00$ \\
\hline & $1388, N 59$ & 40 & 140 & 90 & 349 & 57 & 2104 \\
\hline
\end{tabular}

Without $\mathrm{Mz}$ Restrained at Nodes 85 and 86

\begin{tabular}{|c|c|c|c|c|c|c|c|}
\hline $\begin{array}{l}\text { Moveable } \\
\text { Frame } \\
\text { Position }\end{array}$ & $\begin{array}{l}\text { Beam and } \\
\text { Node } \\
\text { Numbers }\end{array}$ & $\begin{array}{l}\text { Fx } \\
\text { lbs }\end{array}$ & $\begin{array}{l}\text { Fy } \\
\text { lbs }\end{array}$ & $\begin{array}{l}\mathrm{Fz} \\
\mathrm{lbs}\end{array}$ & $\begin{array}{l}M x \\
\text { in-lbs }\end{array}$ & $\begin{array}{l}\text { My } \\
\text { in-los }\end{array}$ & $\begin{array}{l}\text { Mz } \\
\text { in-lbs }\end{array}$ \\
\hline \multirow{2}{*}{\begin{tabular}{l} 
UP \\
\hdashline.
\end{tabular}} & $368 \times 65$ & 70 & 284 & 22 & 28 & 18 & 139 \\
\hline & $1388, N 59$ & 71 & 285 & 22 & 30 & 19 & 143 \\
\hline \multirow{2}{*}{$\begin{array}{l}\text { DOWN } \\
+i: \vdots\end{array}$} & $868, \times 65$ & 21 & 284 & 86 & 402 & 62 & 141 \\
\hline & $3853, x \leq 9$ & $? 1$ & 285 & 86 & 403 & 62 & 143 \\
\hline
\end{tabular}

B-46 


\section{DESIGN CALCULATION}

(1) Drawing H-2.600044 _____ (2) Doc. No.

(3) Page 4.5 of 62

(4) Building

NLA

(5) Rev.

(6) Job No

(7) Subject Core Sampler Tnick Nos $3 \& \& 4$ Shielded Beceiver I ifing Erame Assembly

(8) Originator

E.

Hona

(9) Checker

Cos $\leq 2+1$

Date $4 / 5 / 45$

Date $6-28-95$

IRANSPORT LOADS_ANATXSIS

(Ref. Drawings H-2-690043 and 690044 Sh. 1 \& 2)

WELD JOINT FORCES: (Moveable Frame in Down Position).

MEMBERS (9) TO (9) Frame EIXED

IOINT SKETCH: GLABX COCNONNTES
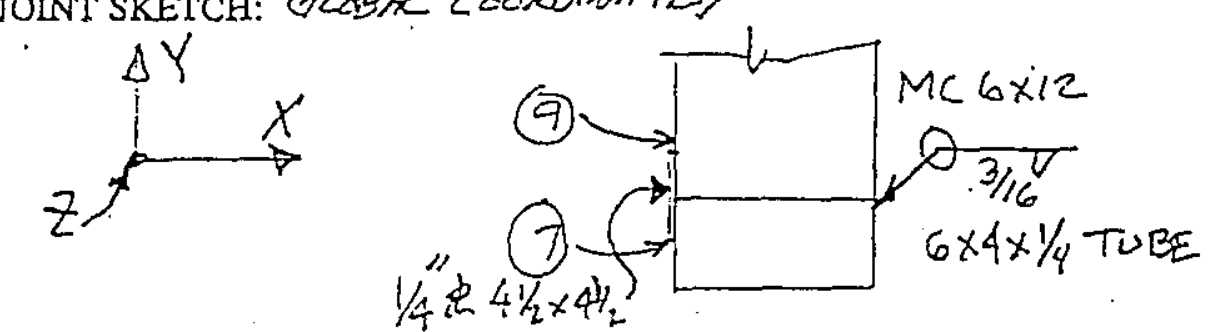

B68, N65

$B S 6, N 59$

With Mz Restrained at Nodes 85 and 86

\begin{tabular}{|l|l|l|l|l|l|l|l|}
\hline $\begin{array}{l}\text { Longitudinal } \\
\text { Load } \\
\text { Direction }\end{array}$ & $\begin{array}{l}\text { Beam and } \\
\text { Node } \\
\text { Numbers }\end{array}$ & $\begin{array}{l}\text { Fx } \\
\text { lbs }\end{array}$ & $\begin{array}{l}\text { Fy } \\
\text { lbs }\end{array}$ & $\begin{array}{l}\text { Fz } \\
\text { lbs }\end{array}$ & $\begin{array}{l}\text { Mix } \\
\text { in-1bs }\end{array}$ & $\begin{array}{l}\text { My } \\
\text { in-lbs }\end{array}$ & $\begin{array}{l}\text { Mz } \\
\text { in-lbs }\end{array}$ \\
\hline FORWARD & $B 68, N 65$ & 729 & 741 & 291 & 9119 & 173 & 23520 \\
\cline { 2 - 9 } & $B 88, N 59$ & 365 & 1516 & 783 & 10210 & 116 & 11700 \\
\hline AFT & $B 68, N 65$ & 304 & 1586 & 465 & 8192 & 94 & 18260 \\
\cline { 2 - 8 } & $B 88, N 59$ & 642 & 1248 & 682 & 12510 & 44 & 28490 \\
\hline
\end{tabular}

Without $M x_{2}$ Restrained at Nodes 85 and 86

\begin{tabular}{|c|c|c|c|c|c|c|c|}
\hline $\begin{array}{l}\text { Longitudinal } \\
\text { Load } \\
\text { Direction }\end{array}$ & $\begin{array}{l}\text { Beam and } \\
\text { Node } \\
\text { Numbers }\end{array}$ & $\begin{array}{l}\text { Fx } \\
\text { lbs }\end{array}$ & $\begin{array}{l}\text { Fy } \\
\text { lbs }\end{array}$ & $\begin{array}{l}\text { Fz. } \\
\text { lbs }\end{array}$ & $\begin{array}{l}\text { Mx } \\
\text { in-lbs }\end{array}$ & $\begin{array}{l}\text { My } \\
\text { in-lbs }\end{array}$ & $\begin{array}{l}\mathrm{Mz} \\
\text { in-lbs }\end{array}$ \\
\hline \multirow[t]{2}{*}{ FORWARD } & $B 68, N 66$ & 424 & 2217 & 291 & 10610 & 151 & 3889 \\
\hline & $388, n 159$ & 96 & 2742 & 784 & 9803 & 106 & 4982 \\
\hline \multirow{2}{*}{ AFT } & ECS,NCS & 55 & 3274 & 509 & 7900 & 156 & 4158 \\
\hline & $388, N 59$ & 256 & 3038 & 583 & 13080 & $1 / 3$ & 3902 \\
\hline
\end{tabular}


RPP-6018, Rev. 0

ANALYTICAL CALCULATIONS

Page 46 of 62

SUbjoc SRLEWELD DOWT STRESS MNALVSES, TZUUEKS $3 x 4$

Originator EIR, YOLLERT

Date $1 / 14195$

Checker

Hean 4.2 ils

Date

Frame $F / X E D$

MEMBERS (9) TO 7

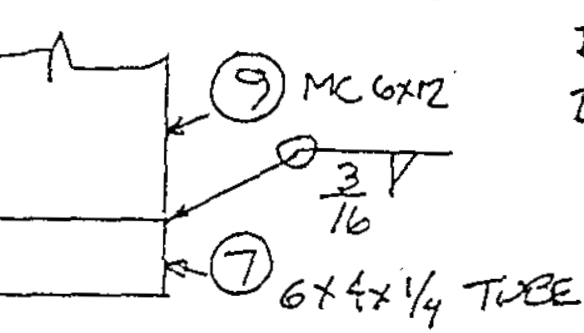

JOINT SKETCH:

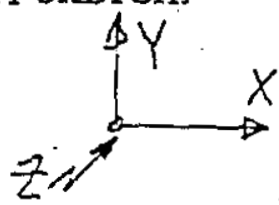

868,165

$1388 N 59$

(MAXMMUM WELO FORCES)

DEAOWEIGHT: $M_{X}=349 \mathrm{~N} \angle B, M Z=2,04 \mu \mathrm{NO}$

TRANSPATATION: $M_{X}=12510 \mathrm{WCE}, M_{Z}=28490 \mathrm{MUS}$

WITHOWT $41 / 2 \times 41 / 2 \times 1 / 4$ GUSSET th THS NONT $153 / 6 "$ FllET RRAUD THE END OF THE MC $4 \times / 2$

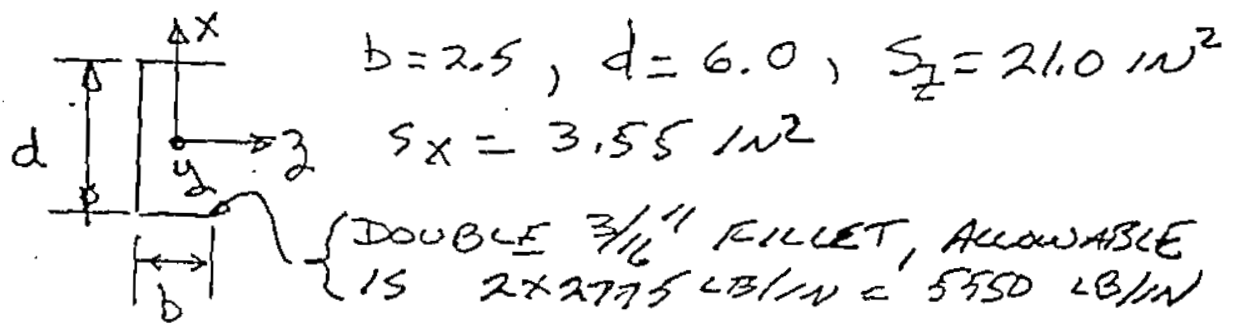

WELD STREST, DEADWEISHT:

$$
\therefore F_{w}=\frac{M_{x}}{S_{x}}+\frac{M_{z}}{S_{z}}=\frac{349}{3.95}+\frac{2104}{21.0}=199 \mathrm{LB} / \mathrm{H}
$$

Fw $2 \times 2700$ LB WW ALWOWARLE.

WELP STRESS, TRANITOPTHTIOKL

$$
F_{w}=\frac{M_{x}}{S_{x}}+\frac{M_{z}}{S_{z}}=\frac{12510}{3.55}+\frac{28490}{.200}=488 / \mathrm{LB} / \mathrm{il}
$$

Fw $<5550 \angle B / N$ ALCOUABLE

$B-48$

B0.6400-060.1 (07/93)

C-97 


\section{DESIGN CALCULATION}
(1) Drawing H-2-690044
(2) Doc. No.
(3) Page 47 of 62
(4) Building
NLA
(5) Rev
(6) Job No
(7) Subject_Core Sampler Truck Nos 3 \& 4 Shielded Receiver Lifting Ename-Assembly
(8) Originator ER, / LueRT
(9) Checker
Hacosin H $\rightarrow$ is
Date 4 h 195
Date $6-30-95$

\section{DEAD WEIGHTT ANALYSTS}

(Ref. Drawings H-2-690043 and 690044 Sh. 1 \& 2)

WEID JOINT FORCES: GLORAC COORD INATES

MEMBERS (7) TO C5X9 ON RIG Frame EIXED

JOINT SKETCH:
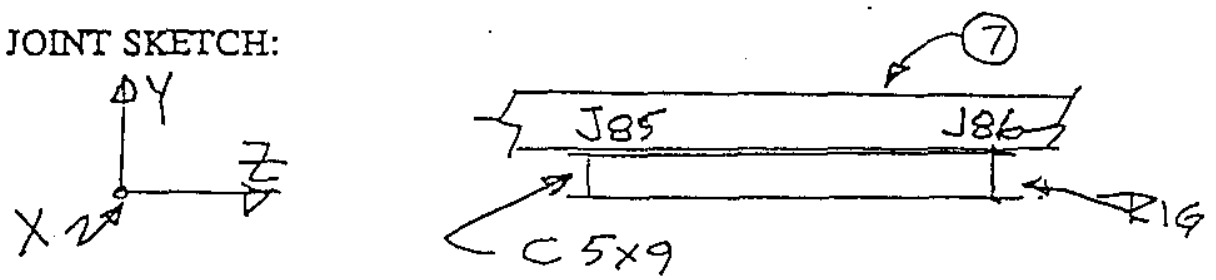

With Mz Restrained at Nodes 85 and 86

\begin{tabular}{|l|l|l|l|l|l|l|l|}
\hline $\begin{array}{l}\text { Moveable } \\
\text { Frame } \\
\text { Position }\end{array}$ & $\begin{array}{l}\text { Beam and } \\
\text { Node } \\
\text { Numbers }\end{array}$ & $\begin{array}{l}\text { Fx } \\
\text { lbs }\end{array}$ & $\begin{array}{l}\text { Fy } \\
\text { lbs }\end{array}$ & $\begin{array}{l}\text { Fz } \\
\text { lbs }\end{array}$ & $\begin{array}{l}\text { Mx } \\
\text { in-lbs }\end{array}$ & $\begin{array}{l}\text { My } \\
\text { in-lbs }\end{array}$ & $\begin{array}{l}\text { Mz } \\
\text { in-lbs }\end{array}$ \\
\hline $\begin{array}{l}\text { UP } \\
\therefore \cdots\end{array}$ & 185 & 36 & 91 & 472 & 0 & 0 & 2281 \\
\cline { 2 - 9 } & 186 & 35 & 89 & 472 & 0 & 0 & 2275 \\
\hline $\begin{array}{l}\text { DOWN } \\
\therefore \quad \cdots\end{array}$ & 185 & 40 & 109 & 479 & 0 & 0 & 2024 \\
\cline { 2 - 8 } & 186 & 40 & 108 & 479 & 0 & 0 & 2020 \\
\hline
\end{tabular}

Without Mz Restrained at Nodes 85 and 86

\begin{tabular}{|c|c|c|c|c|c|c|c|}
\hline $\begin{array}{l}\text { Moveable } \\
\text { Frame } \\
\text { Position }\end{array}$ & $\begin{array}{l}\text { Beam and } \\
\text { Node } \\
\text { Numbers }\end{array}$ & $\begin{array}{l}\text { Fx } \\
\text { lbs }\end{array}$ & $\begin{array}{l}\text { Fy } \\
\text { lbs }\end{array}$ & $\begin{array}{l}\mathrm{Fz} \\
\mathrm{lbs}\end{array}$ & $\begin{array}{l}\text { Mx } \\
\text { in-lbs }\end{array}$ & $\begin{array}{l}\text { My } \\
\text { in-lbs }\end{array}$ & $\begin{array}{l}M x \\
\text { in-lbs }\end{array}$ \\
\hline \multirow[t]{2}{*}{ UP } & 185 & 71 & 253 & 1119 & $\sigma$ & 0 & 0 \\
\hline & 186 & 70 & 251 & 1119 & 0 & 0 & 0 \\
\hline \multirow[t]{2}{*}{ DOWN } & $\sqrt{85}$ & $7 \%$ & 253 & 1098 & 0 & 0 & 0 \\
\hline & $\sqrt{86}$ & 7) & 252 & 1048 & 0 & 0 & 0 \\
\hline
\end{tabular}




\section{DESIGN CALCULATION}

(1) Drawing $\mathrm{H}-2=600044$

(4) Building_ NLA

(2) Doc. No.

(3) Page 48 of 62

(6) Job No.

(7) Subject Core Sampler Truck Nos 3 \& 4 Shielded Receiver Lifting Eame Assembly

(8) Originator F.R. 1 1 $0 \leq 4 R T$

(9) Checker Haesa $H$.

Date $4 / 7 / 4 i$

Date $6-32-55$

TRANSEORT LOADSANALYSIS

(Ref. Drawings H-2-690043 and 690044 Sh. 1 \& 2)

WELD JOINT FORCES: (Moveable Frame in Domn Position)

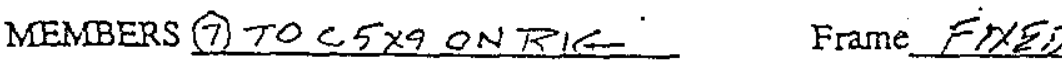

JOINT SKETCH: GLOBAL COORDINATES<smiles>C#CC(O)=[V]</smiles>

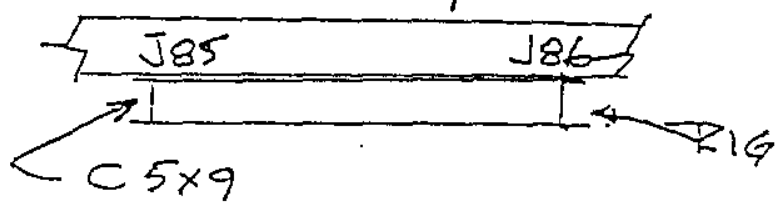

With $\mathrm{Mz}_{2}$ Restrained at Nodes 85 and 86

\begin{tabular}{|l|l|l|l|l|l|l|l|}
\hline $\begin{array}{l}\text { Longitudinal } \\
\text { Load } \\
\text { Direction }\end{array}$ & $\begin{array}{l}\text { Beam and } \\
\text { Node } \\
\text { Numbers }\end{array}$ & los & $\begin{array}{l}\text { Fy } \\
\text { los }\end{array}$ & Fz & los & My & Mz \\
\hline FORWARD & $\mathrm{J} 85$ & $16 /$ & 300 & 4136 & 0 & 0 & 12040 \\
\cline { 2 - 9 } & 186 & 960 & 668 & 5233 & 0 & 0 & 25430 \\
\hline \multirow{2}{*}{ AFT } & 186 & 857 & 37 & 5692 & 0 & 0 & 30200 \\
\cline { 2 - 9 } & 186 & 116 & 2796 & 4582 & 0 & 0 & 18500 \\
\hline
\end{tabular}

Without Mz Restrained at Nodes 85 and 86

\begin{tabular}{|c|c|c|c|c|c|c|c|}
\hline $\begin{array}{l}\text { Longitudinal } \\
\text { Load } \\
\text { Direction }\end{array}$ & $\begin{array}{l}\text { Beam and } \\
\text { Node } \\
\text { Numbers }\end{array}$ & $\begin{array}{l}\text { Fx } \\
\text { los }\end{array}$ & $\begin{array}{l}\text { Fy } \\
\text { los }\end{array}$ & $\begin{array}{l}\mathrm{Fz} . \\
\text { los }\end{array}$ & $\begin{array}{l}\mathrm{Mx} \\
\text { in-lbs }\end{array}$ & $\begin{array}{l}\text { My } \\
\text { in-lbs }\end{array}$ & $\begin{array}{l}\mathrm{Mz} \\
\text { in-lbs }\end{array}$ \\
\hline \multirow[t]{2}{*}{ FORWARD } & $J 85$ & 87 & $4 / 24$ & 9340 & 0 & 0 & $\infty$ \\
\hline & 186 & 634 & $9 / 0$ & 10440 & 0 & 0 & $\rightarrow$ \\
\hline \multirow[t]{2}{*}{ AFT } & 485 & 456 & $|80|$ & 12600 & 0 & 0 & $\infty$ \\
\hline & 386 & 228 & 4936 & 11480 & 0 & 0 & 0 \\
\hline
\end{tabular}

B- 50 


\section{ANALYTICAL CALCULATIONS}

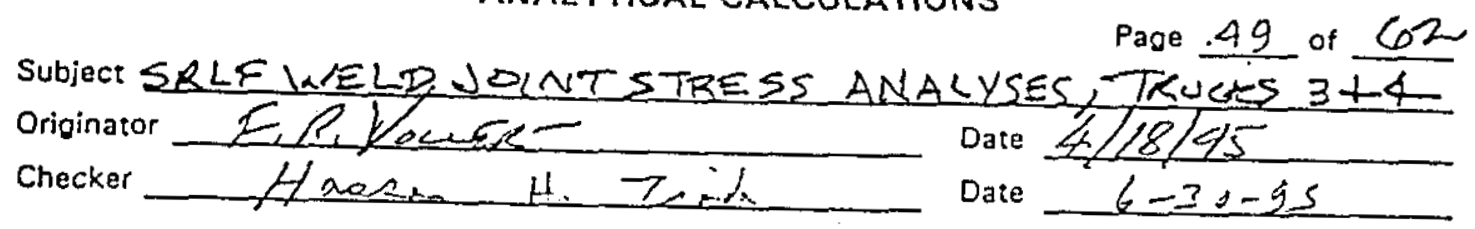

MEMDERS (7) TO $55 \times 9$ ow $P I G$ Frame EIXER

JOINT SKETCE:
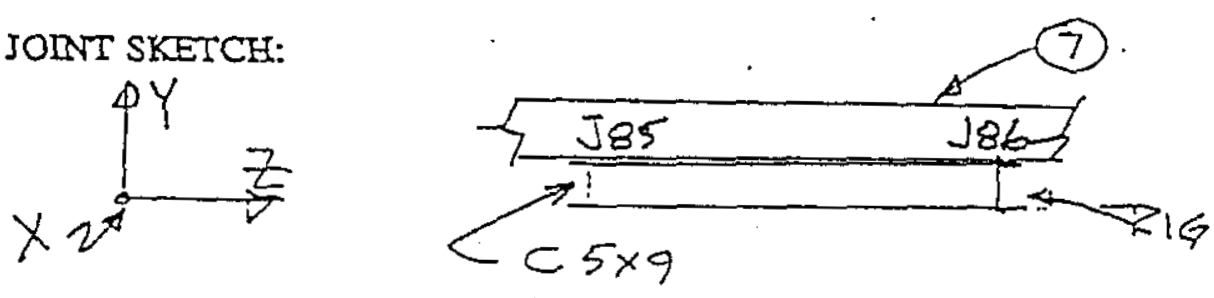

MAXMMUN FORCES

(DEAOWEIGHT) $M_{Z}=2275 \mathrm{NL}$

(TRAMSPORTATION) $M_{3}=30200 \mathrm{NN}$ NOTE) $\frac{A y}{2 D-6 \times 4 \times 1 / 4 \text { TUBE (7) PROVIOES LITTLE }}$

NOTE: THIS WELD

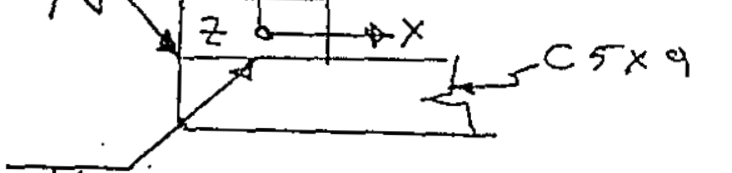

$T$ PRESUME CENTER OF Mz ROTATION AT.E(?) $J_{z}=\frac{6^{3}}{12}+6 \times 2^{2}=42 \mathrm{~N}^{3}, r^{\prime}=\sqrt{3^{2}+2^{2}}=3.60 \mathrm{~N}$

WELD STRESSES

DEADWE(GCT) $F_{\omega}=\frac{M_{z} r^{\prime}}{J_{3}}=\frac{2275 \times 3.60}{42}=195 \frac{\mathrm{LB}}{\mathrm{IN}}$ of

(TRANSPORTATION)

$E_{2}=\frac{M_{Z} \Gamma^{\prime}}{I_{w}}=\frac{30200 \times 3.60}{42}=2589 \mathrm{col} / \mathrm{N}$

$F w=2589 \mathrm{cBlw}<2775 \mathrm{cBl} / \mathrm{w}$ sudwrect 


\section{DESIGN CALCULATION}

(1) Drawing H-2-690044

(2) Doc. No.

(3) Page 50 of 62

(4) Building

N/A

(5) Rev

(6) Job No.

(T) Subject Core Sampler Tnck Nos 3 \& 4 Shieided Receiver I ifting Exame Assembly

(8) Originator FiR, LescERT

(9) Checker toses H. Zidh Date_4/4/95 Date $6-20-95$

\section{DEAD WEIGHT ANALYSTS}

(Ref. Drawings H-2-690043 and 690044 Sh. 1 \& 2)

WELD JOINT FORCES: GLOBAC COORONUHTHES

MEMBERS (3) TO (6) Frame $E 1 X E 2$

JOINT SKETCH:
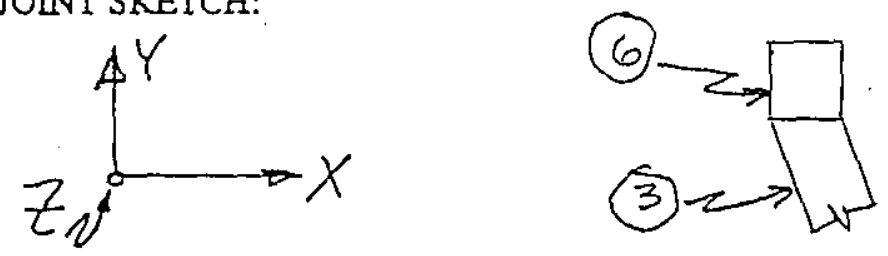

B80, N77

$B 82, N 80$

With Mz Restrained at Nodes 85 and 86

\begin{tabular}{|l|l|l|l|l|l|l|l|}
\hline $\begin{array}{l}\text { Moveable } \\
\begin{array}{l}\text { Frame } \\
\text { Position }\end{array}\end{array}$ & $\begin{array}{l}\text { Beam and } \\
\text { Node } \\
\text { Numbers }\end{array}$ & $\begin{array}{l}\text { Fx } \\
\text { Ibs }\end{array}$ & $\begin{array}{l}\text { Fy } \\
\text { lbs }\end{array}$ & $\begin{array}{l}\text { Fz } \\
\text { lbs }\end{array}$ & $\begin{array}{l}\text { Mx } \\
\text { in-lbs }\end{array}$ & $\begin{array}{l}\text { My } \\
\text { in-lbs }\end{array}$ & $\begin{array}{l}\text { Mz } \\
\text { in-lbs }\end{array}$ \\
\hline $\begin{array}{l}\text { UP } \\
\therefore\end{array}$ & $B 80, N 7$ & 36 & 203 & 13 & 384 & 126 & 170 \\
\hline \multirow{2}{*}{$\begin{array}{l}\text { DOWN } \\
\therefore \quad\end{array}$} & $B 82, N 80$ & 35 & 202 & 13 & 383 & 126 & 170 \\
\cline { 2 - 9 } & $B 82, N 80$ & 40 & 222 & 12 & 358 & 91 & 118 \\
\hline
\end{tabular}

Without Mz Restrained at Nodes 85 and 86

\begin{tabular}{|c|c|c|c|c|c|c|c|}
\hline $\begin{array}{l}\text { Moveable } \\
\text { Frame } \\
\text { Position } \\
\end{array}$ & $\begin{array}{l}\text { Beam and } \\
\text { Node } \\
\text { Numbers }\end{array}$ & $\begin{array}{l}\text { Fx } \\
\text { los }\end{array}$ & $\begin{array}{l}\text { Fy } \\
\text { lbs }\end{array}$ & $\begin{array}{l}\mathrm{Fz} \\
\mathrm{lbs}\end{array}$ & $\begin{array}{l}\text { Mx } \\
\text { in-1bs }\end{array}$ & $\begin{array}{l}\text { My } \\
\text { in-lbs }\end{array}$ & $\begin{array}{l}\mathrm{Mz} \\
\text { in-lbs }\end{array}$ \\
\hline \multirow[t]{2}{*}{ UP. } & $B 80, N>7$ & 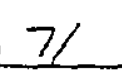 & 366 & 23 & 677 & 148 & 68 \\
\hline & $B 82, \sim 80$ & 70 & 364 & 23 & 676 & 192 & 67 \\
\hline \multirow[t]{2}{*}{ DOWN } & $380,4>1$ & 71 & 366 & 21 & 623 & 15.9 & 30 \\
\hline & $B 82, N 80$ & 71 & 365 & 21 & 622 & 158 & 30 \\
\hline
\end{tabular}




\section{DESIGI CALCULATION}

(1) Drawing E-2-690044

(2) Doc. No.

(3) Page 51 of 62

(4) Building__ N/A

(5) Rev

(6) Job No.

(7) Subject Core Sampler Tnuck Nos 3\&4 Shielded_Receiver Lifting Erame Assembly

(8) Originator F.R Voce ERT

(9) Checker

Hosere H. 2 ada

Date $4 / 6 / 95$

Date $6-30-25$

TRANSPORTIOADSANATYSTS

(Ref. Drawings H-2-690043 and 690044 Sh. 1 \& 2)

WELD JONNT FORCES: (Moveable Frame in Down Position)

MEMBBERS (3) TO (6) Frame FIXEP

JOINT SKETCH: GLOBAL COOZDINATES

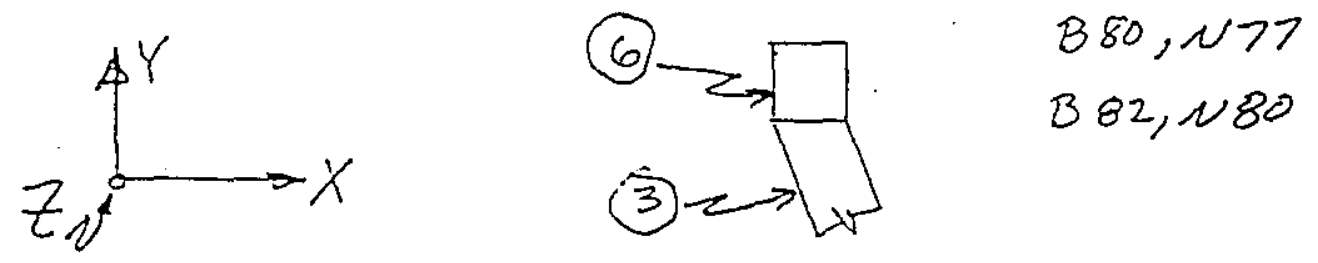

With Mz Restrained at Nodes 85 and 86

\begin{tabular}{|c|c|c|c|c|c|c|c|}
\hline $\begin{array}{l}\text { Longitudinal } \\
\text { Load } \\
\text { Direction }\end{array}$ & $\begin{array}{l}\text { Beam and } \\
\text { Node } \\
\text { Numbers }\end{array}$ & $\begin{array}{l}\mathrm{Fx} \\
\mathrm{lbs}\end{array}$ & $\begin{array}{l}\text { Fy } \\
\text { Ibs }\end{array}$ & $\begin{array}{l}\mathrm{Fz} \\
\mathrm{Ibs}\end{array}$ & $\begin{array}{l}M x \\
\text { in-lbs }\end{array}$ & $\begin{array}{l}\text { My } \\
\text { in-lbs }\end{array}$ & $\begin{array}{l}\mathrm{Mz} \\
\text { in-lbs }\end{array}$ \\
\hline \multirow[t]{2}{*}{ FORWARD } & $B 80, N 77$ & 183 & 920 & 160 & 4364 & 399 & 384 \\
\hline & $1382, \sqrt{ } 80$ & 233 & 1146 & 66 & 1618 & 225 & 477 \\
\hline \multirow[t]{2}{*}{ AFT } & $880, N 77$ & 326 & 1739 & 24 & 473 & 372 & 190 \\
\hline & $1382, N 80$ & 238 & 1287 & 189 & 5280 & 1012 & 275 \\
\hline
\end{tabular}

Without Mz Restrained at Nodes 85 and 86

\begin{tabular}{|c|c|c|c|c|c|c|c|}
\hline $\begin{array}{l}\text { Longitudinal } \\
\text { Load } \\
\text { Direction }\end{array}$ & $\begin{array}{l}\text { Beam and } \\
\text { Node } \\
\text { Numbers }\end{array}$ & $\begin{array}{l}\text { Fx } \\
\text { lbs }\end{array}$ & $\begin{array}{l}\text { Fy } \\
\text { lbs }\end{array}$ & $\begin{array}{l}\mathrm{Fz} \\
\mathrm{ibs}\end{array}$ & $\begin{array}{l}\text { Mx } \\
\text { in-1bs }\end{array}$ & $\begin{array}{l}\text { My } \\
\text { in-lbs }\end{array}$ & $\begin{array}{l}\mathrm{Mz} \\
\text { in-lbs }\end{array}$ \\
\hline \multirow[t]{2}{*}{ FORWARD } & $280, N 77$ & 446 & $2 / 50$ & 225 & 6252 & 231 & 1208 \\
\hline & $B 82, N 8 D$ & 544 & 2618 & 1 & 221 & 213 & 1410 \\
\hline \multirow[t]{2}{*}{ AFT. } & $880, N 71$ & 714 & 3550 & 85 & 2099 & .1257 & 919 \\
\hline & $B 83 N 80$ & 596 & 2953 & 292 & $8 \% 44$ & 1768 & 729 \\
\hline
\end{tabular}


RPP-6018, Rev. 0

ANALYTICAL CALCULATIONS

Page 52 of 62

Subject SRLE WELD LOINT STRESE ANASYSES, PRUCKS $3-64$

Originator $E R, V O C E R$

Checker Hansar H. 7 ids

Date $4 / 18 / 155$

Date $6-3 a-25$

MEMBERS (3) TO 6

Frame EIXED

JOINT SKETCH:
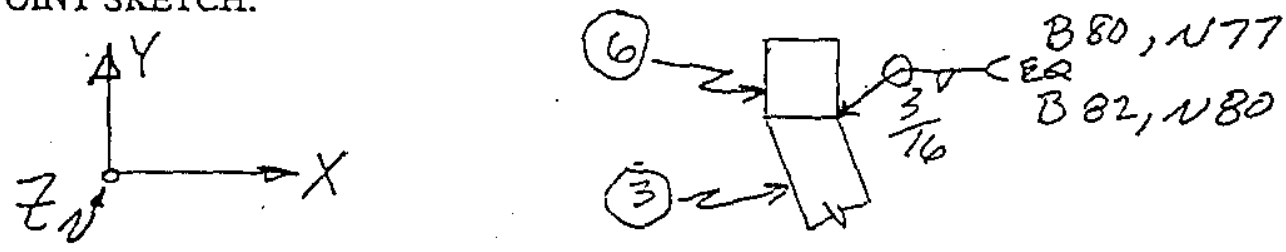

MAXIMLM FOR EES

(DEAOWEIGAT) $F_{y}=366 \mathrm{LB}, M_{x}=677 \mathrm{~N}-\angle \mathrm{R}$

(TRANSPORTATION) $F_{y}=2953, M_{x}=8404, M_{y}=1768$

(WELO JexNT)

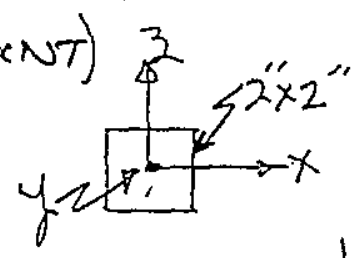

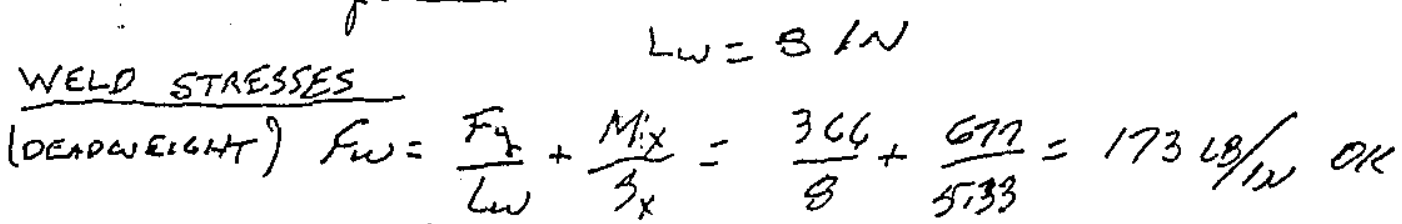

(TRANSPORTATION)

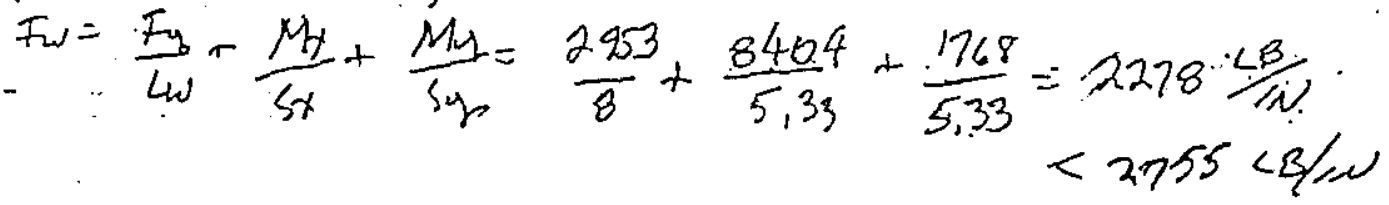

B-54

80-6400-060.1(07/93)

C-103 


\section{DESIGN CALCULATION}

(1) Drawing $\mathrm{H}-2-690044$

(2) Dœ. No.

(3) Page 53 of 62

(4) Building

N/A

(5) Rev.

(ด) Job No

(7) Subject Care Sampler Tnuck Nos 3_\&4 Shielded Receiver Lifting Erame,Assembly

(8) Originator Fi R. Kos ERT

(9) Checker

Hacer

H. Z is

Date $414 / 95$

Date $6-30-95$

DEAD WEIGHT ANALYSIS

(Ref. Drawings H-2-690043 and 690044 Sh. 1 \& 2)

WEID JOINT FORCES: LOCAL COSRDIATES

MEMBERS (3) TO (3) LAUER ED Frame FIXES

JOINT SKETCH:
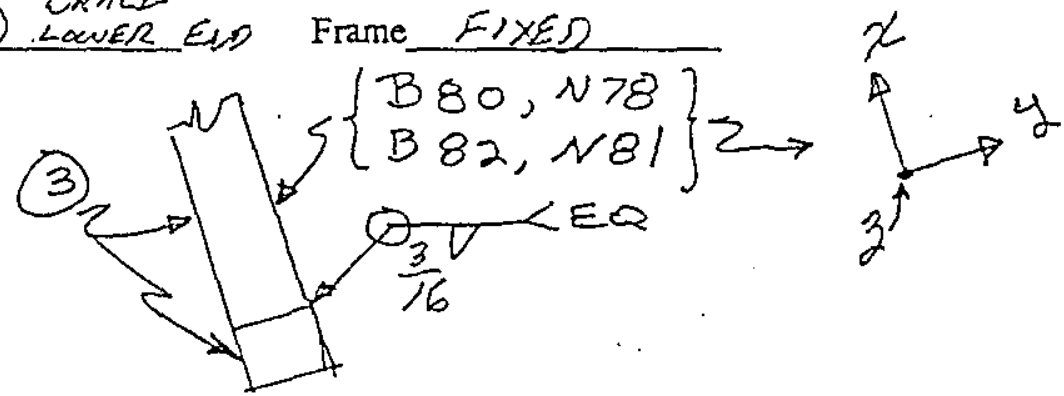

With Mz Restrained at Nodes 85 and 86

\begin{tabular}{|c|c|c|c|c|c|c|c|}
\hline $\begin{array}{l}\text { Moveable } \\
\text { Frame } \\
\text { Position }\end{array}$ & $\begin{array}{l}\text { Beam and } \\
\text { Node } \\
\text { Numbers }\end{array}$ & $\begin{array}{l}\text { Fx } \\
\text { lbs }\end{array}$ & $\begin{array}{l}\text { Fy } \\
\text { lbs }\end{array}$ & $\begin{array}{l}\mathrm{Fz} \\
\mathrm{Ibs}\end{array}$ & $\begin{array}{l}\text { Mx } \\
\text { in-1bs }\end{array}$ & $\begin{array}{l}\text { My } \\
\text { in-lbs }\end{array}$ & $\begin{array}{l}\mathrm{Mz} \\
\text { in-lbs }\end{array}$ \\
\hline \multirow[t]{2}{*}{ UP } & $B 80, N 78$ & 229 & 4 & 13 & 58 & 282 & 69 \\
\hline & 382,181 & 228 & 4 & 13 & 58 & 281 & 69 \\
\hline \multirow{2}{*}{ DOWN } & $1380, N 78$ & 248 & 2 & 12 & 28 & 280 & 93 \\
\hline & 882,181 & 248 & 2 & 12 & 27 & 280 & 93 \\
\hline
\end{tabular}

Without Mz Restrained at Nodes 85 and 86

\begin{tabular}{|c|c|c|c|c|c|c|c|}
\hline $\begin{array}{l}\text { Moveable } \\
\text { Frame } \\
\text { Position }\end{array}$ & $\begin{array}{l}\text { Beam and } \\
\text { Node } \\
\text { Numbers }\end{array}$ & $\begin{array}{l}\text { Fx } \\
\text { lbs }\end{array}$ & $\begin{array}{l}\text { Fy } \\
\text { lbs }\end{array}$ & $\begin{array}{l}\mathrm{Fz} \\
\mathrm{lbs}\end{array}$ & $\begin{array}{l}\mathrm{Mx} \\
\text { in-lbs }\end{array}$ & $\begin{array}{l}\text { My } \\
\text { in-lbs }\end{array}$ & $\begin{array}{l}\mathrm{Mz} \\
\text { in-lbs }\end{array}$ \\
\hline \multirow[t]{2}{*}{ UP } & $380, v>8$ & 396 & 2 & 23 & 78 & 491 & 304 \\
\hline & $(382,281$ & 394 & 2 & 23 & 78 & 490 & 304 \\
\hline \multirow[t]{2}{*}{ DOWN } & $580, N>B$ & 396 & 3 & 21 & 49 & 468 & 300 \\
\hline & $38^{2}, 181$ & 395 & 3 & 21 & 49 & 467 & 300 \\
\hline
\end{tabular}

$B-55$ 


\section{DESIGN CALCULATION}

(1) Drawing $\mathrm{H}-2-690044$

(4) Building__ N/A

(2) Do. No.

(3) Page 54 of 62

(7) Subject Core Sampler TruckNos 3 \& 4 Shielded Receiver Liftiog Erame Assembly

(8) Originator $E, R-V 0<E R T$

(9) Checker Hasane H. Pejd

Date $4 / 6 / G$

Date $6-3,-5 s$

IRANSRORT IOADS ANAIYSIS

(Ref. Drawings H-2-690043 and 690044 Sh. 1 \& 2)

WELD JOINT FORCES: (Moreable Frame in Dorn Position)

MEMBERS (3) TO (3) BRAEE ENO FrameFIXED

JONNT SKETCH:

LoCAL COARONATES
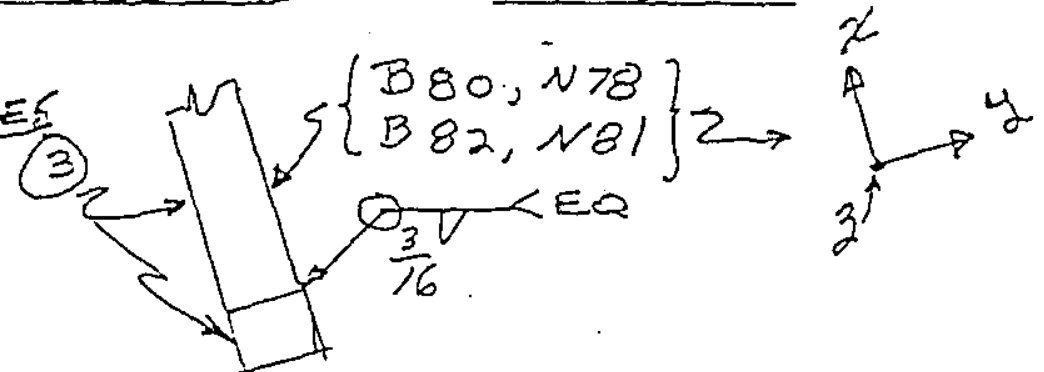

With Mz Restrained at Nodes 85 and 86

\begin{tabular}{|l|l|l|l|l|l|l|l|}
\hline $\begin{array}{l}\text { Longitudinal } \\
\text { Load } \\
\text { Direction }\end{array}$ & $\begin{array}{l}\text { Beam and } \\
\text { Node } \\
\text { Numbers }\end{array}$ & $\begin{array}{l}\text { Fx } \\
\text { lbs }\end{array}$ & $\begin{array}{l}\text { Fy } \\
\text { lbs }\end{array}$ & $\begin{array}{l}\text { Fz } \\
\text { lbs }\end{array}$ & $\begin{array}{l}\text { Mx } \\
\text { in-lbs }\end{array}$ & $\begin{array}{l}\text { My } \\
\text { in-lbs }\end{array}$ & $\begin{array}{l}\text { Mz } \\
\text { in-lbs }\end{array}$ \\
\hline FORWARD & $B 80, N 78$ & 912 & 37 & 169 & 358 & 4235 & $1 / 96$ \\
\cline { 2 - 9 } & $382, N 81$ & 1143 & 42 & 74 & 56 & 2033 & 1616 \\
\hline \multirow{2}{*}{ AFT } & $380, N 78$ & 1798 & 27 & 33 & 448 & 1074 & 1466 \\
\hline
\end{tabular}

Without Mr Restrained at Nades 85 and 86

\begin{tabular}{|c|c|c|c|c|c|c|c|}
\hline $\begin{array}{l}\text { Longitudinal } \\
\text { Load } \\
\text { Direction }\end{array}$ & $\begin{array}{l}\text { Beam and } \\
\text { Node } \\
\text { Numbers }\end{array}$ & $\begin{array}{l}\text { Fx } \\
\text { lbs }\end{array}$ & $\begin{array}{l}\text { Fy } \\
\text { lbs }\end{array}$ & $\begin{array}{l}\text { Fz } \\
\text { ibs }\end{array}$ & $\begin{array}{l}\text { Mx } \\
\text { in }-1 b s\end{array}$ & $\begin{array}{l}\text { My } \\
\text { in-lbs }\end{array}$ & $\begin{array}{l}\mathrm{Mz} \\
\mathrm{in}-\mathrm{lbs}\end{array}$ \\
\hline \multirow[t]{2}{*}{ FORWARD } & $(38), 1,18$ & 2169 & 84 & 234 & 356 & 5706 & 2834 \\
\hline & 382,1131 & 2647 & 100 & 8 & 163 & 478 & 3430 \\
\hline \multirow[t]{2}{*}{$\mathrm{AFT}$} & 1380.1718 & 3649 & 97 & 76 & 756 & .1253 & 4033 \\
\hline & Bar 1181 & 3040 & 83 & 301 & 295 & 6924 & 3503 \\
\hline
\end{tabular}


SUbjec SRLF WELD JONNT STRESS ANALVISES TRUCKS $3 \times 4$ Orioinator F. $R$ VOLLETET

Checker Hasen H. Zikh Date $4 / 8 / 15$ Date $6-36-25$

LOCAL COORONATES

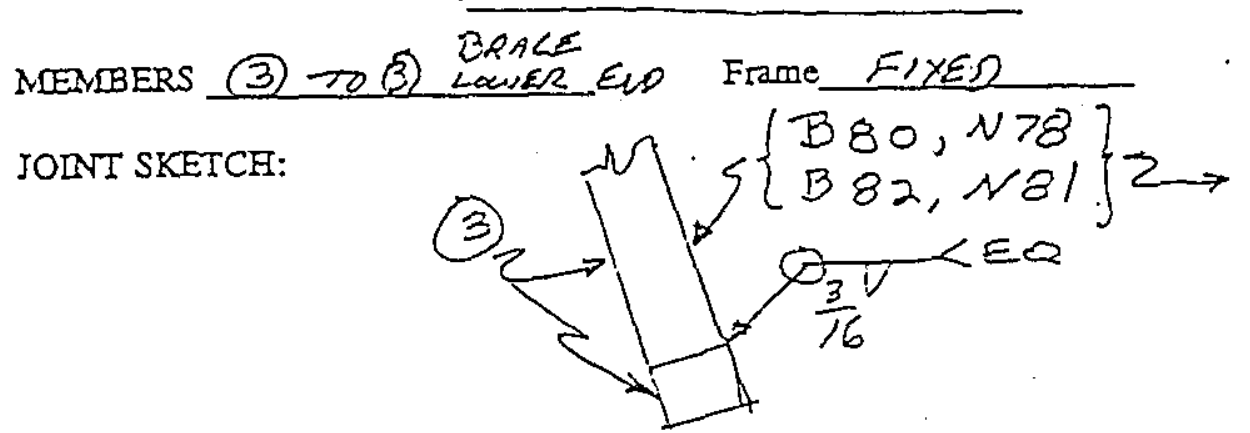

$\not$

MAXIMUM FORLES

(DEAOWELCNT) $M_{y}=468 \mathrm{NLB}, M_{z}=300 \mathrm{NLCB}$

(TRANSPORTATTON) $F_{i}=3040 \angle 8, M_{y}=6924 \mathrm{NLB}$

$M_{z}=3503 \quad N-\angle B$

FOR WELO AROUNO SNO OF $2 \times 2 \times 1 / 4$ TUBE

$s_{y}=s_{2}=5.33 \mathrm{~m}^{2}, L_{i}=4 \times 2=8 \mathrm{~N}$

wELO STRESSAS

FOR DEADWElGFt: $F_{\omega}=\frac{M_{4}}{s_{4}}+\frac{M_{3}}{S_{3}}=\frac{468+300}{.5 .33}=\frac{144 \mathrm{cg}}{\mathrm{OK}}$

FOR TRANSPORTATION:

$$
\begin{aligned}
& F_{w}=\frac{F_{x}}{L_{w}}+\frac{M_{y}}{S_{4}}+\frac{M_{3}}{S_{3}}=\frac{3040}{8}+\frac{6924+3503}{S_{m} 3}=2336 \mathrm{LB} \mathrm{N} \\
& F_{\text {er }}=2336 . \mathrm{cB} / \mathrm{N}<2775 \mathrm{cB} / \mathrm{w} \text { quswren }
\end{aligned}
$$




\section{DESIGN CALCULATION}

(1) Drawing $1 \mathrm{H}-2-690044$

(4) Building

NLA

(2) Doc. No.

(3) Page 56 of 62

(6) Yob No.

(7) Subjoct Core Sampler Truck Nos 3\&4 Shielded Roceiver Lifting Enme Assambly

(8) Originator FR Voecert

(9) Checker.

Hesse 14.724

Date 4/6/95

Dare $(-30-15$

\section{DEAD WEIGET ANAITSTS}

(Ref. Drawings H-2-690043 and 690044 Sh. 1\& 2)

WELD JOINT FORCES: LOCAC COORDUUATES

MEMIBERS 3 WELDED TO $55 \times 9$ Frame FIXEO

JODT (ON R(G)

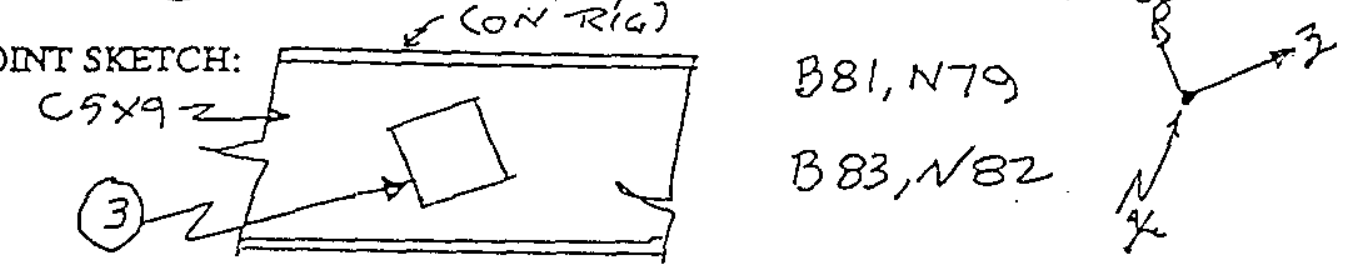

With Mz Restrained at Nodes 85 and 86

\begin{tabular}{|c|c|c|c|c|c|c|c|}
\hline $\begin{array}{l}\text { Moveable } \\
\text { Frame } \\
\text { Position }\end{array}$ & $\begin{array}{l}\text { Beam and } \\
\text { Node } \\
\text { Numbers }\end{array}$ & $\begin{array}{l}\text { Fx } \\
\text { Ibs }\end{array}$ & $\begin{array}{l}\text { Fy } \\
\text { Ibs }\end{array}$ & $\begin{array}{l}F z \\
\text { lbs }\end{array}$ & $\begin{array}{l}\text { Mx } \\
\text { in-Ibs }\end{array}$ & $\begin{array}{l}\text { My } \\
\text { in-libs }\end{array}$ & Miz \\
\hline \multirow[t]{2}{*}{ UP } & $381, \sim>9$ & 13 & 232 & 4 & 69 & 38 & 871 \\
\hline & $883, N 82$ & 13 & 230 & 4 & 69 & 3 & 866 \\
\hline \multirow[t]{2}{*}{ DOWN } & $381, N 79$ & 12 & 251 & 3 & 93 & 14 & 967 \\
\hline & $B 83, v 832$ & 12 & 250 & 3 & 93 & 14 & 964 \\
\hline
\end{tabular}

Without Mz Restrained at Nodes 85 and 86

\begin{tabular}{|c|c|c|c|c|c|c|c|}
\hline $\begin{array}{l}\text { Moveable } \\
\text { Frame } \\
\text { Position }\end{array}$ & $\begin{array}{l}\text { Beam and } \\
\text { Node } \\
\text { Numbers }\end{array}$ & $\begin{array}{l}\text { Fx } \\
\text { lbs }\end{array}$ & $\begin{array}{l}\text { Fy } \\
\text { lbs }\end{array}$ & $\begin{array}{l}\mathrm{Fz} \\
\mathrm{bbs}\end{array}$ & $\begin{array}{l}\text { Max } \\
\text { in-lbs }\end{array}$ & $\begin{array}{l}\text { My } \\
\text { in-lbs }\end{array}$ & $\begin{array}{l}\mathrm{MLz} \\
\mathrm{in}-\mathrm{lbs}\end{array}$ \\
\hline \multirow[t]{2}{*}{ UP } & $381, \times 79$ & 23 & 398 & 2 & 304 & 90 & 1493 \\
\hline & $B 83, N 82$ & 23 & 396 & 2 & 304 & 89 & 1487 \\
\hline \multirow[t]{2}{*}{ DOWN } & $381, N>9$ & 21 & 398 & 3 & 300 & 64 & 1518 \\
\hline & $883, \sim 82$ & 21 & 3017 & 3 & 300 & 64 & 1514 \\
\hline
\end{tabular}




\section{DESIGN CAICULATION}

(1) Drawing $\mathrm{H}-2-690044$ (2) Doc. No. (3) Page 57 of 62

(4) Building NLA

(5) Rev.

(6) Job No.

(7) Subject Core Sampler Truck Nos 3 \& 4_Shielded Receiver I Ifting_Emme_Assembly

(8) Originator E,R Lruefert

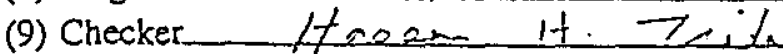
Date $4 / 6 / 95$ Date $6-32-9 s$

\section{TRANSPORT COADSANALYSTS}

(Ref. Drawings H-2-690043 and 690044 Sh. 1 \& 2)

WELD JOINT FORCES: (Moveable Frame in Domn Position)

MEMIBERS (3) WELOED TO $55 \times 9$ Frame FIXED LOCAL COORINATES (ON RIG)

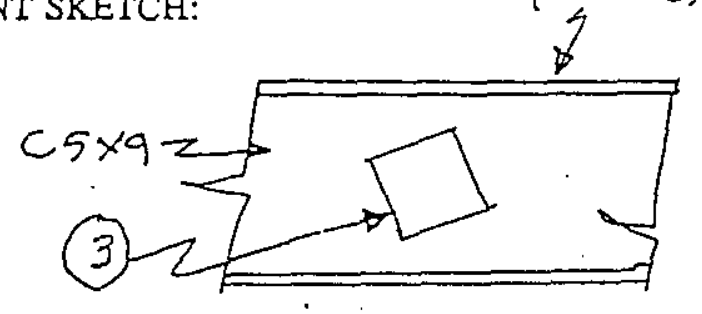

$B 81, N 79$ $B 83, \sqrt{82}$

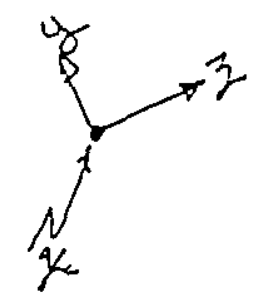

With Mz Restrained at Nodes 85 and 86

\begin{tabular}{|c|c|c|c|c|c|c|c|}
\hline $\begin{array}{l}\text { Longitudinal } \\
\text { Load } \\
\text { Direction }\end{array}$ & $\begin{array}{l}\text { Beam and } \\
\text { Node } \\
\text { Numbers }\end{array}$ & $\begin{array}{l}F x \\
\text { lbs }\end{array}$ & $\begin{array}{l}\text { Fy } \\
\text { lbs }\end{array}$ & $\begin{array}{l}\mathrm{Fz} \\
\text { Ibs }\end{array}$ & $\begin{array}{l}\text { Mx } \\
\text { in-1bs }\end{array}$ & $\begin{array}{l}\text { Mry } \\
\text { in-lbs }\end{array}$ & $\begin{array}{l}\text { Mzz } \\
\text { in-lbs }\end{array}$ \\
\hline \multirow[t]{2}{*}{ FORWARD } & $B 81,19$ & 170 & 910 & 36 & 1146 & 121 & $32 /$ \\
\hline & 883,182 & 75 & $\| \mathrm{c} /$ & 49 & $16 / 6$ & 292 & 744 \\
\hline \multirow[t]{2}{*}{ AFT } & $1381, \sqrt{179}$ & 33 & $180<$ & 28 & 1466 & 584 & 10070 \\
\hline & $883 \sim 82$ & 199 & 1341 & 18 & 1075 & 179 & 1863 \\
\hline
\end{tabular}

Without Mz Restrained at Nodes 85 and 86

\begin{tabular}{|c|c|c|c|c|c|c|c|}
\hline $\begin{array}{l}\text { Longitudinal } \\
\text { Load } \\
\text { Direction } \\
\end{array}$ & $\begin{array}{l}\text { Beam and } \\
\text { Node } \\
\text { Numbers }\end{array}$ & $\begin{array}{l}\text { Fx } \\
\text { ibs }\end{array}$ & $\begin{array}{l}\text { Fy } \\
\text { lbs }\end{array}$ & $\begin{array}{l}\mathrm{Fz} \\
\mathrm{ibs}\end{array}$ & $\begin{array}{l}M x x \\
\text { in-lbs }\end{array}$ & $\begin{array}{l}\text { My } \\
\text { in-lbs }\end{array}$ & $\begin{array}{l}\mathrm{Mz} \\
\text { in-lbs }\end{array}$ \\
\hline \multirow[t]{2}{*}{ FORWARD } & $(88), N>9$ & 234 & 2167 & 86 & 2824 & 70 & $5 / 33$ \\
\hline & 1883,482 & 9 & 2644 & 101 & 3430 & 666 & 13710 \\
\hline \multirow[t]{2}{*}{ AFT } & 381,179 & 76 & 3652 & 98 & 4033 & 1244 & 17000 \\
\hline & $B 83, N 82$ & 302 & 3043 & 84 & 3503 & 714 & \\
\hline
\end{tabular}

$$
\text { B }-59
$$


RPP-6018, Rev. 0

ANALYTICAL CALCULATIONS

Page 58 of 62

Subject SRLF WELD dow STESSS AN KVSE, TRUKCS $3+4$ Orioinator $E, R$ VeuELT Date 4/25/45

Checker $H \operatorname{sen} H=-Z<\alpha_{x}$ Date $6-20-55$

MEMIBERS (3) WELDED TO $\leqslant 5 \times 9$ Frame FIXEO

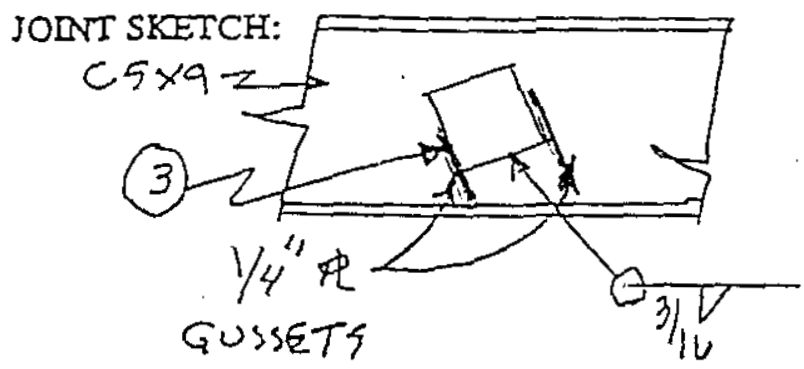

$B 81, N 79$

$B 83, \sqrt{ } 82$

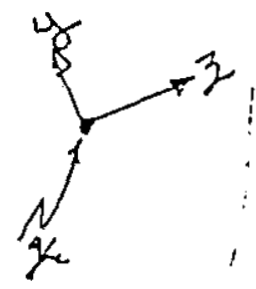

LOCAC

COORDINATES

MAXIMUM LUELD FORLSS

(DEADUELGHT:) $M Z=1518 \mathrm{lN} \angle B$

(TRANSPORTASTLON) $F_{y}=3652 \mathrm{LB}, M=4033 \mathrm{wLB}$,

$M_{y}=1244$ WLB, $M_{z}=17000 \mathrm{NLB}$

WELD TO TUBE AND GUSSTS:

$$
\begin{aligned}
& \frac{y^{y} 5^{2 \times 2}}{y}=\frac{8 \times 1+2 \times 3 \times 2}{14}=1.43^{1 \mathrm{~N}}
\end{aligned}
$$

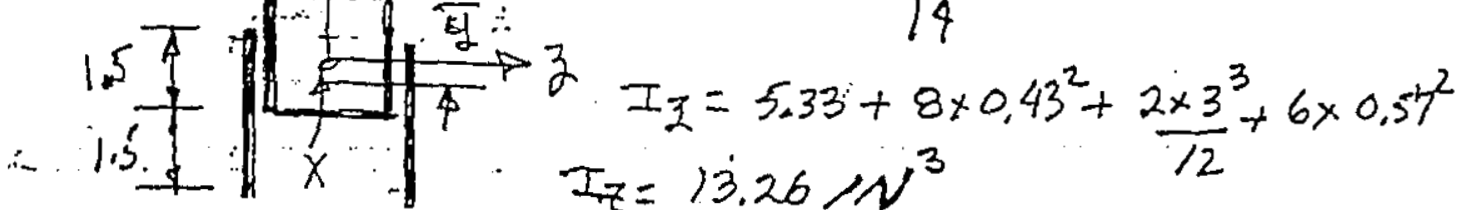

$$
\begin{aligned}
& \therefore s_{z}=\frac{13.26}{2.07}=6.41 \\
& I_{y}=5.33+2 \times 3=11.33 \\
& \text { syc } 11.33 \\
& J_{\omega}=24.54 \mathrm{~m}^{3} \\
& \Gamma^{\prime}=\sqrt{1^{2}+2.07^{2}}=2.30 \mathrm{w}
\end{aligned}
$$

$$
\begin{aligned}
& \text { WELD STRESSES } \\
& \text { (DEADWEIGHT) } \\
& F_{\omega}=\frac{M Z}{T_{Z}}=\frac{1518}{6,41}=237 \mathrm{CB} / \mathrm{N} \text { OK } \\
& B-60
\end{aligned}
$$

BD.6400-060.1 (07/93)

C-109 
RPP-6018, Rev. 0

ANALYTICAL CALCULATIONS

Page 59 of 62

SUbject SRLFWELD WUNT STEESS ANRLYSES, DRUCKS $3-4$

Orioinator $E R$ hlowet

Checker

Hasar H. Ziln

Date $4 / 2 \mathrm{C} / \mathrm{s}^{-}$

Date $\frac{4}{6-30-25}$

(3) WECDED TO $C 5 \times 9$ CONTHUED

$$
\begin{aligned}
& \text { WELD STRESSES, (TRANSPORTATIOU) } \\
& F_{w}=\frac{M y}{S_{y}}+\frac{M_{z}}{s_{z}}=\frac{1244}{11.33}+\frac{17000}{6.41}=2762 \mathrm{LB} / \mathrm{N}
\end{aligned}
$$

GUSSET TR ETRESSES.

PLATES ACT WITH.TUBESASCOMPOSITE SECTIOW.

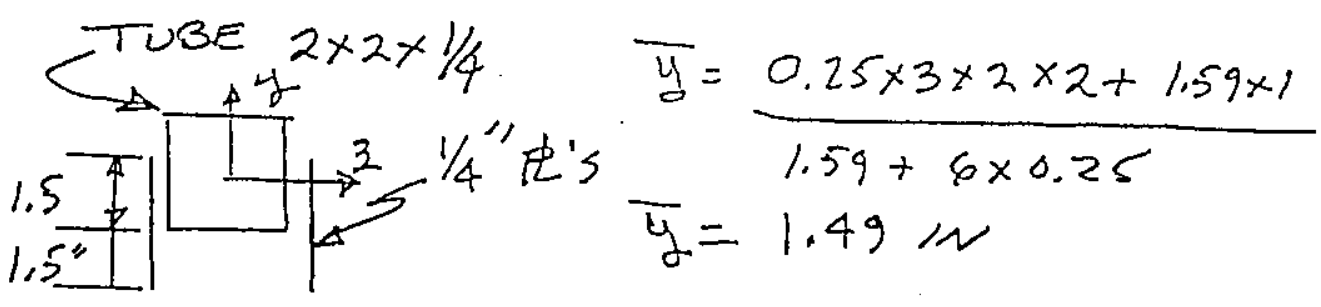

$$
\begin{aligned}
& I_{3}=0.766+1.59 \times 0.49^{2}+0.25 \times 3^{3} \times 2 \\
& I_{3}=3.83 \mathrm{w}^{4} \quad S_{3}=\frac{I_{z}}{2.01}=1.91 \mathrm{wn}^{3} \\
& I_{y}=0.766+2 \times 3 \times 1=6.766 \mathrm{~N}^{4} \\
& S_{y}=6.766 \mathrm{w}^{2}
\end{aligned}
$$

(DEADCEIHT)

$$
F=\frac{M_{3}}{S_{I}}=\frac{1518}{1.91}=795 \mathrm{ps} 1 \text { ok }
$$

(TRANSPOCTATIOC)

$$
\begin{aligned}
& f=\frac{M_{4}}{S_{y}}+\frac{M_{3}}{s_{3}}=\frac{1244}{6.744}+\frac{17000}{1.91}=908491 \\
& f=23760 \text { P5I Buwande }
\end{aligned}
$$

$B-61$

BD-6400-060.1 (07/93)

C-110 
ANALYTICAL CALCULATIONS

Page 60 of 62

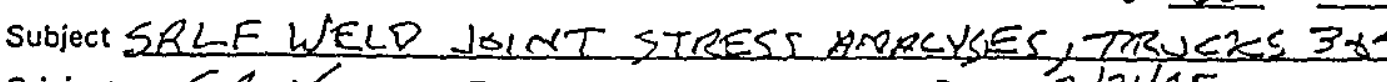

Originator $F, R_{1} \backslash \angle L \leq E R T$

Date $3 / 3 / 195$

Checker

Hanaw H. Zaida

Date

$6-30-i 5$

ALTUATOR SUPPORT

$H-2-690043$
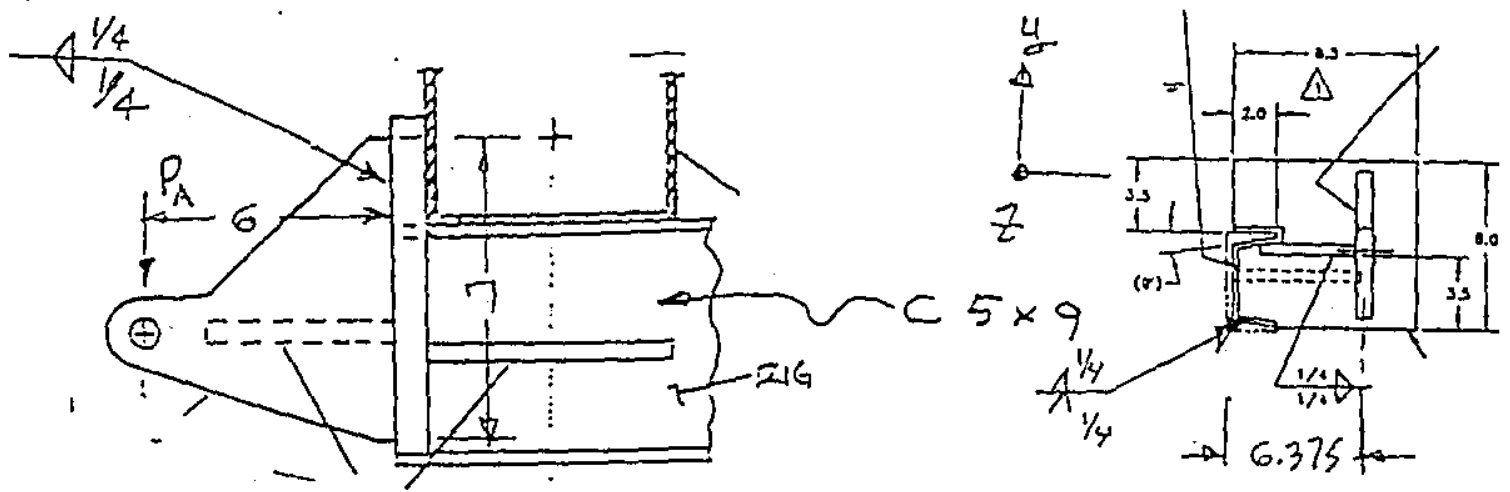

WITH AND WITHOUT MZ RESTRAINT AT NODES $85 \times 86$

\begin{tabular}{c|c|c|c}
\hline FRAME & DEADWEIGMT & TRAMSFORT & TRANSPORT \\
POATON & (PA) & FUD & (FA) AFT \\
\hline UP & 1690 & $\searrow$ & $X$ \\
\hline DOWT & 1681 & $253 \%$ & 2671
\end{tabular}

DEADWEIEHT ANACYSAS U WELD STRESSES

$$
\begin{aligned}
& \left(90^{\circ} \text { WECD JOLNT } 7 \text { " LONG }\right) \\
& F y=P_{A}=1690 \mathrm{LB} \mathrm{MAX} \\
& M_{z}=6 \times P_{4}=6 \times 1690=10140 \mathrm{~N} \mathrm{~N}-6 \mathrm{~B}
\end{aligned}
$$

$\therefore$ EUEEID SHERR $F_{w, S}=\frac{3}{2} \times \frac{F y}{7}=362 \mathrm{LB} / 1 \mathrm{~N}$

Beroointe STRESS FW, $B=\frac{M_{Z}}{S_{E}}=\frac{10140 \times 6}{7^{2}}=1242 \mathrm{LB}$

$$
\sqrt{\sum E_{\omega}^{2}}=\sqrt{362^{2}+1242^{2}}=1294 \mathrm{cB/2}
$$

OR $\frac{1294}{2}=647$ LB/IN ON EACT $1 / 4$ "FILLET

647 LB/IN 3370.0 LB/IN ALCOW ABLE

$B-62$

$80.6400 .060 .1\{07 / 93\}$

C-111 
RPP-6018, Rev. 0

ANALYTICAL CALCULATIONS

Page 6.1 of 62

Subject SRLE LUELO JOINT STRESS BNACLEE, TRZCKS $3+4$ Originator $E R$. VoLCERT

Checker Hoes H. Zuder

Date $4 / 13 / 25$

Date $6-30-55$

ALTUATOR SCPPORT CONT WUER

(DERD WEISHT) WELD HT $C 5+9$

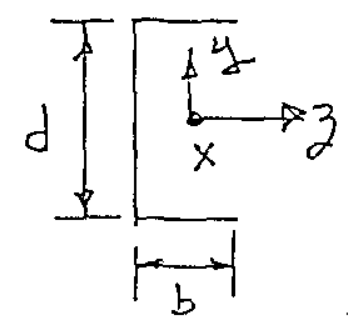

troRsiow? $b=1.885, d=5.0, \bar{z}=0.478$

$s_{3}=13.61 \mathrm{~N}^{2}, d_{\omega}=37 \mathrm{~N}^{3}, r=2.87$

$F_{y}=P_{A}=1690 \angle B \quad M A X$

$M_{z}=F_{y} \times 6.75=11408 \mathrm{~m} \angle B$

$M_{x}=F_{y} \times(6.375-\overline{3})=9966 \mathrm{kN} \mathrm{CB}$

WGLD STRESSES

(SHEAR), $F_{W, S}=\frac{F_{y}}{(2 b+d)}=\frac{1690}{8.77}=193 \mathrm{Ls} / \mathrm{m}$

(ToRsiou stiEAR) $F_{\omega, T}=\frac{M_{x} r^{\prime}}{J_{\omega}}=773 \mathrm{LB} / \mathrm{N}$.

(ZENDina) $F_{w, 3}=\frac{M_{z}}{\sum_{z}}=\frac{11408}{13.6}=839 \mathrm{Ls/1}$

$\sqrt{\sum F_{\omega}^{2}}=\sqrt{966^{2}+839^{2}}=1279 \cdot \angle B / N$

$1279 \mathrm{LB} / \mathrm{N}<2755 \mathrm{LB} / \mathrm{N}$ HLCWWALE FOR

3/6" F《LCT EQUUKCUT

B-63

$80-6400-060.1107 / 931$

C-112 
RPP-6018, Rev. 0

ANALYTICAL CALCULATIONS

Page 62 of 62

SUbjectSRLF WELD JUNI TIRESS ANALYSES, TZUCKE 364

Originator EIR, VoLCERT

Checker

Haseno. $H=2 \pi d x$

Date $4 / 14195$

Date $\frac{1-30-1 s}{10}$

ALTUATOR SUPPORT COMTUUED

TRANSPORTATION LOAD ANALYSLS, WELO STRESSES

( $.90^{\circ}$ WECD JONT)

$F_{y}=2671 \mathrm{LB}(M, A)$

BY PROPORTION: SHEAR FW, $=\frac{2671}{1690} \times 362=572 \frac{\mathrm{cB}}{\mathrm{N}}$

AND BENDWG $F_{\omega, B}=\frac{2671}{1690} \times 1242=1963 \mathrm{LB} / \mathrm{NO}$

$\sqrt{\sum F_{\varphi}^{2}}=\sqrt{572^{2}+1963^{2}}=2045 \mathrm{LB} / \mathrm{NN}$ OR:

$\frac{2045}{2}=1023 \mathrm{LB} / \mathrm{N}$ का EACH $/ 4$ "FKLET

$1023<3 / 4 x \leqslant 3700<B / H N$ ALLOWABLE

(WESO AT $C 5 \times 9)$

(SHEAR) FWU, $=\frac{3671}{1690} \times 193=305$ LElü

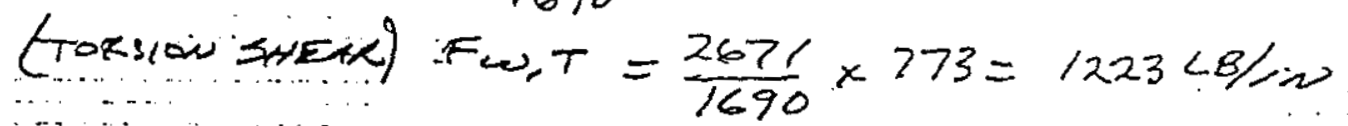

$F_{w i s}+F_{w, T}=1528 \mathrm{CB} / \mathrm{TN}$

(BENDWS) $-F_{\omega, B}=\frac{2671}{1640}+839=1326 \mathrm{LP} / \mathrm{m}$

$\sqrt{\sum F_{\omega}^{2}}=\sqrt{1528^{2}+1326^{2}}=2023 \angle B / i$

$3 / \mathrm{k} "$ FILCET EODWU, ALCOWABCE $=2000 \mathrm{LB} / \mathrm{m}$

IS REOWIRED FOR TRANPARTATIOU LOAD

$1 / 2$ "EQUIN WELD THICKNESS ENIST, OK

$B-64$

B0.6400-060.1 (07/93)

C-113 